\title{
Inorganic and Radiochemical Analysis of 241-C-104 Tank Waste
}

\author{
S. K. Fiskum \\ C. J. Barinaga \\ J. P. Bramson \\ K. J. Carson \\ J. R. DesChane \\ O. T. Farmer \\ L. R. Greenwood \\ F. V. Hoopes \\ R. T. Ratner
}

\author{
D. R. Sanders \\ M. J. Steele \\ R. T. Steele \\ C. Z. Soderquist \\ R. G. Swoboda \\ K. K. Thomas \\ T. L. Trang-Le \\ M. W. Urie \\ J. J. Wagner
}

October 2000

Prepared for

CH2M Hill Hanford Group under Project Number 41503

Pacific Northwest National Laboratory

Richland, Washington 99352 



\section{DISCLAIMER}

This report was prepared as an account of work sponsored by an agency of the United States Government. Neither the United States Government nor any agency thereof, nor any of their employees, make any warranty, express or implied, or assumes any legal liability or responsibility for the accuracy, completeness, or usefulness of any information, apparatus, product, or process disclosed, or represents that its use would not infringe privately owned rights. Reference herein to any specific commercial product, process, or service by trade name, trademark, manufacturer, or otherwise does not necessarily constitute or imply its endorsement, recommendation, or favoring by the United States Government or any agency thereof. The views and opinions of authors expressed herein do not necessarily state or reflect those of the United States Government or any agency thereof. 


\section{DISCLAIMER}

Portions of this document may be illegible in electronic image products. Images are produced from the best available original document. 


\section{Summary}

Battelle received $2.3 \mathrm{~kg}$ of Hanford tank waste material from tank 241-C-104 distributed over 14 sample jars. The contents of all jars were mixed to provide a single composite. The composite was homogenized and representative sub-samples were collected, and then separated into supernatant and wet solids fractions. The individual fractions were analyzed for organic, radiochemical and inorganic composition, as defined in Test Plan BNFL-29953-30, in support of regulatory activities. This report presents the inorganic (including TCLP metals) and radiochemical results. Organic analyte results are reported in WTP-RPT-008 (Draft), Organic Analysis of C-104 Tank Waste.

The characterization analyses of the as received material for C-104 include:

-- Inductively-coupled plasma spectrometry for $\mathrm{Ag}, \mathrm{Al}, \mathrm{As}, \mathrm{B}, \mathrm{Ba}, \mathrm{Be}, \mathrm{Bi}, \mathrm{Ca}, \mathrm{Cd}$, $\mathrm{Co}, \mathrm{Cr}, \mathrm{Cu}, \mathrm{Fe}, \mathrm{K}, \mathrm{Li}, \mathrm{Mg}, \mathrm{Mn}, \mathrm{Mo}, \mathrm{Na}, \mathrm{Ni}, \mathrm{P}, \mathrm{Pb}, \mathrm{Pd}, \mathrm{Rh}, \mathrm{Sb}, \mathrm{Se}, \mathrm{Si}, \mathrm{Sn}, \mathrm{Tl}, \mathrm{U}$, $\mathrm{V}, \mathrm{W}, \mathrm{Y}, \mathrm{Zn}$, and $\mathrm{Zr}$ (although not specified in the test plan Ce, La, Nd, Sr, Th, and $\mathrm{Ti}$ were also measured and are reported for information only)

- Radiochemical analyses for total alpha and total beta activity, H-3, C-14, Co-60, Se-79, Sr-90, Nb-94, Ru-106/Rh-106, Sb-125, Sn-126, Cs-134, Cs-137, Eu-154, Eu-155, Pu-238, Pu-239+240, Pu-241, Am-241 (by GEA and AEA), Cm-242, and $\mathrm{Cm}-243+244$ (Pu-236 was also reported for information only)

-- Inductively-coupled plasma mass spectrometry for Pr, Pt, Rb, Ta, Tc-99, I-127, I-129, Cs-133 U-233, U-234, U-235, U-236, Np-237, U-238, Pu-239, Pu-240 (total $U$ was also reported for information only)

-- Total uranium by kinetic phosphorescence

-- Ion chromatography for $\mathrm{Br}^{-}, \mathrm{Cl}, \mathrm{F}, \mathrm{NO}_{2}^{-}, \mathrm{NO}_{3}{ }^{-}, \mathrm{PO}_{4}^{-3}$, and $\mathrm{SO}_{4}{ }^{-2}$ (oxalate, $\mathrm{C}_{2} \mathrm{O}_{4}{ }^{-2}$, was also measured and reported for information only since oxalate is reported with organic anions as part of the organic analyte report)

-- Mercury, cyanide, ammonia, and inorganic, organic, and total carbon

-- Free hydroxide and $\mathrm{pH}$ determination (supernatant only)

-- Flashpoint determination (supernatant only)

Except for a few cases, the characterization results met or exceeded the quality control requirements established by the governing quality assurance plan, and met or exceeded the minimum reportable quantity requirements specified by BNFL. Whenever possible the analyses were performed to SW-846 protocols so that the results can be used to support permit application, as well as to provide feed envelope characterization data. 



\section{Terms and Abbreviations}

$\begin{array}{ll}\text { AEA } & \text { alpha energy analysis } \\ \text { ALARA } & \text { as low as reasonably achievable } \\ \text { ASR } & \text { analytical services request } \\ \text { BNFL } & \text { BNFL, Inc; subsidiary of British Nuclear Fuels, Ltd. } \\ \text { COC } & \text { chain of custody } \\ \text { CVAA } & \text { cold vapor atomic absorption } \\ \text { EQL } & \text { estimated quantitation level } \\ \text { GEA } & \text { gamma energy analysis } \\ \text { HLRF } & \text { High Level Radiation Facility } \\ \text { IC } & \text { ion chromatography } \\ \text { ICP } & \text { inductively coupled plasma/atomic emission spectrometry } \\ \text { ICP/MS } & \text { inductively coupled plasma/mass spectrometry } \\ \text { ISE } & \text { ion specific electrode } \\ \text { LCS } & \text { laboratory control standard } \\ \text { MDL } & \text { method detection limit } \\ \text { MRQ } & \text { minimum reportable quantity } \\ \text { MSA } & \text { method of standard addition } \\ \text { NIST } & \text { National Institute of Standards and Technology } \\ \text { \%D } & \text { percent difference } \\ \text { PB } & \text { process blank } \\ \text { QA } & \text { quality assurance } \\ \text { QC } & \text { quality control } \\ \text { RPD } & \text { relative percent difference } \\ \text { RPL } & \text { Radiochemical Processing Laboratory } \\ \text { SAL } & \text { Shielded Analytical Laboratory } \\ \text { SRM } & \text { Standard Reference Material } \\ \text { TC } & \text { total carbon } \\ \text { TCLP } & \text { toxicity characteristic leaching procedure } \\ \text { TDS } & \text { total dissolved solids } \\ \text { TIC } & \text { total inorganic carbon } \\ \text { TOC } & \text { total organic carbon } \\ \text { W-DOE } & \text { Washington State Department of Ecology } \\ & \end{array}$




\section{Units}

$\begin{array}{ll}{ }^{\circ} \mathrm{C}-{ }^{\circ} \mathrm{F} \text { degrees } & \text { Centigrade / degrees Fahrenheit } \\ \mathrm{g} & \text { gram } \\ \mathrm{g} / \mathrm{mL} & \text { gram per milliliter } \\ \mathrm{keV} & \text { kiloelectron volts } \\ \mathrm{kPa} & \text { kilopascal } \\ \mu \mathrm{g} / \mathrm{g}-\mu \mathrm{g} / \mathrm{mL} & \text { microgram per gram / microgram per milliliter } \\ \mu \mathrm{Ci} / \mathrm{g}-\mu \mathrm{Ci} / \mathrm{mL} & \text { microcurie per gram / microcurie per milliliter } \\ \mathrm{mL} & \text { milliliter } \\ \mathrm{mmole} / \mathrm{mL} & \text { millimole per milliliter } \\ \mathrm{rpm} & \text { revolutions per minute } \\ \mathrm{Vol} \% & \text { volume percent } \\ \mathrm{Wt} \% & \text { weight percent }\end{array}$




\section{Contents}

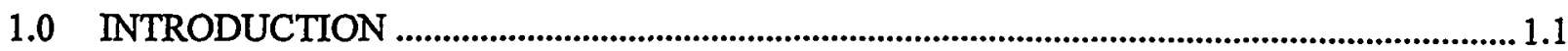

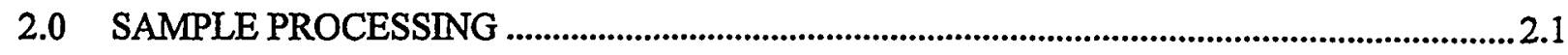

2.1 Total Dissolved Solids and Weight Percent Solids ................................................................2.1

2.2 Phase Separation ................................................................................................................ 2.1

2.3 Supernatant Density Measurements ................................................................................2.2

2.4 Initial Preparation of Supernatants and Solids .....................................................................2.2

3.0 ANALYSIS RESULTS FOR ANALYTES OF INTEREST .......................................................

4.0 TCLP METALS ANALYSIS AND EVALUATION...................................................................

5.0 QUALITY CONTROL AND DATA EVALUATION ……......................................................

5.1 Metals Analysis by ICP - Table 3.1............................................................................... 5.1

5.2 Uranium Analysis by Kinetic Phosphorimetry- Table 3.1 .................................................. 5.2

5.3 Radiochemical Analysis -Table 3.2 ................................................................................ 5.2

5.3.1 Gamma Emitters by Gamma Energy Analysis (GEA) .......................................... 5.2

5.3.2 Total Alpha and Total Beta .............................................................................5.3

5.3.3 Plutonium, Americium, and Curium .................................................................5.3

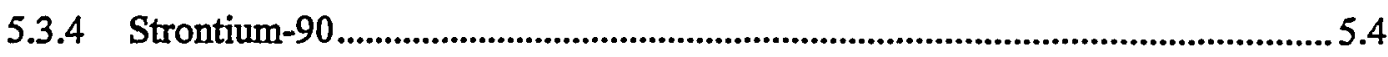

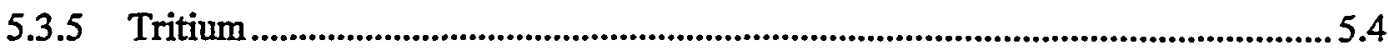

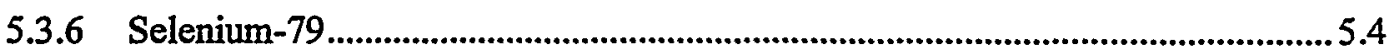

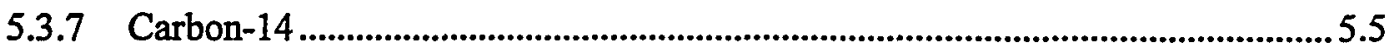

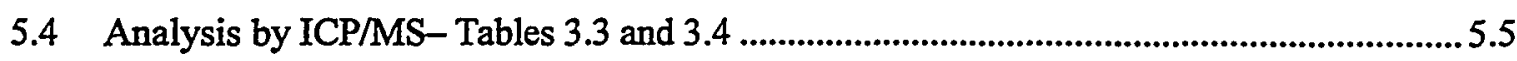

5.5 TOC/TIC Analysis by Hot Persulfate/Coulometry - Table 3.5 ............................................5.7

5.6 Anion Analysis by IC - Table 3.5 …............................................................................ 5.8

5.7 Mercury Analysis by CVAA - Table 3.5 ............................................................................ 5.9

5.8 Ammonia Analysis by ISE - Table 3.5 ......................................................................... 5.9

5.9 Total Cyanide Analysis by Distillation/Colorimetry - Table 3.5 ……………….................. 5.9

5.10 Flashpoint Determination - Table 3.5 ............................................................................5.10

5.11 Free Hydroxide and pH Analysis - Table 3.5 …………......................................................5.10

6.0 METHOD DETECTION LIMITS \& MINIMUM REPORTABLE QUANTITIES .....................6.1

APPENDIX A: TEST PLAN AND ASR …………........................................................................

APPENDIX B: ANALYTICAL DATA ……............................................................................... 


\section{Figures}

Figure 1.1. Compositing and Sub-sampling for C-104 As-Received Analytical Samples .................. 1.2

Figure 2.1. Flow Diagram for Analytical Preparation of Supernatant and Solids.

\section{Tables}

Table 2.1. Slurry Vol\% and Wt\% Solids, TDS, and Centrifuged Solids Wt\% Solids......................... 2.1

Table 2.2. Density Results for C-104 Supernatant Composite ............................................................ 2.2

Table 3.1. C-104 As-Received --- ICP Metals Results ................................................................... 3.2

Table 3.2. C-104 As-Received --- Radiochemical Results ........................................................... 3.3

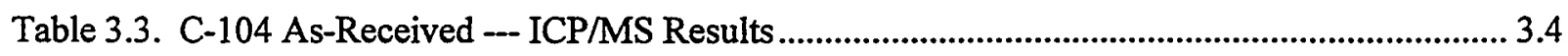

Table 3.4. C-104 As-Received Cs and U Mass Abundance Ratios ................................................... 3.5

Table 3.5. C-104 As-Received --- Other Results ............................................................................ 3.6

Table 4.1. TCLP Metals Predicted Maximum Concentrations ............................................................... 4.2

Table 5.1. Comparison of ICP/MS to Other Methods for Pu-239+240 and Total U........................ 5.7

Table 6.1 Comparison of Measurement MDLs to Target MRQs ...................................................... 6.2 


\subsection{Introduction}

This report presents the inorganic and radiochemical analytical results for Hanford waste tank 241-C-104 (C-104) as-received materials. The analyses were conducted in support of the BNFL Proposal No. 30406/29274 Task 5.0. The inorganic and radiochemical analysis results obtained from the as-received materials are used to provide initial characterization information for subsequent process testing and to provide data to support permit application activities. The governing Quality Assurance (QA) Plan "Conducting Analytical Work in Support of Regulatory Programs" provided the operational and quality control protocols for the analytical activities, and whenever possible, analyses were performed to SW-846 equivalent methods and protocols.

The inorganic and radiochemical analytes of interest and recommended methods are defined in the BNFL proposal and Test Plan BNFL-29953-30 Revision 0. All inorganic and radiochemical analytes of interest defined by these documents are reported. Estimated method detection limits (MDL) are provided where analytes of interest were not detected. Certain other originally requested analyses have not been performed based on agreements between Battelle, BNFL, and/or W-DOE. These inorganic analyses are total sulfide, reactive sulfide, reactive cyanide, total sulfur, total nitrogen, total iodine, and stainless steel corrosion testing.

Per the analysis protocols established by the QA Plan, process blanks, samples, duplicates, blank spikes (or lab control standards) and matrix spikes (or post spikes) were analyzed, as appropriate. Recoveries for quality control samples (such as matrix spikes and blank spikes) are discussed in this report and evaluated for their effect on the reported results if they failed to meet the acceptance criteria of the QA Plan. All analytical data and QC results are included in the Project File 29274 (Record Inventory and Disposition Schedule, Technical Support to BNFL for Phase 1B, T5.5).

The composite of the C-104 as-received material was prepared per Test Plan BNFL-29953-31, Revision 0. The C-104 composite (from 14 shipping jars) was prepared in a three-liter stainless steel vessel with a bottom drain spigot. A bladed stainless steel impeller was used to homogenize the material. While the composite was being stirred, the composite was drained into three $125-\mathrm{mL}$ glass jars to demonstrate the ability to obtain representative sub-samples. These sub-samples were allowed to settle for a minimum of 16 hours. After this settling period, the volume percent of settled solids in each of the 125 -mL glass jars was similar (i.e., $88.9 \%$ to $89.9 \%$ ), providing indication that the sub-samples were representative of the composite. Following confirmation of representative sub-sampling, the remaining composite was re-agitated and three additional 500-mL glass bottles were used to sub-sample the remainder of the C-104 composite into fractions labeled C-104 Comp C, C-104 Comp D, and C-104 Comp E. These latter four fractions were allowed to stand for 5 weeks. The supernatant was collected and combined into one fraction, C-104 Sup A. The supernatant was observed to be red and the centrifuged solids were observed to be green.

Figure 1.1 provides the sample flow diagram for the preparation of the $\mathrm{C}-104$ as-received analytical characterization sub-samples. Two containers of C-104 composite slurry (C-104 Comp A and C-104 Comp B) and one container of composite supernatant (C-104 SUP A) were allocated for organic, inorganic, and radiochemical characterization. The compositing and sub-sampling operations were conducted in the High Level Radiation Facility (HLRF). The sub-samples were transferred under chainof-custody (COC) to the Shielded Analytical Laboratory (SAL) for characterization analysis preparation and distribution. 


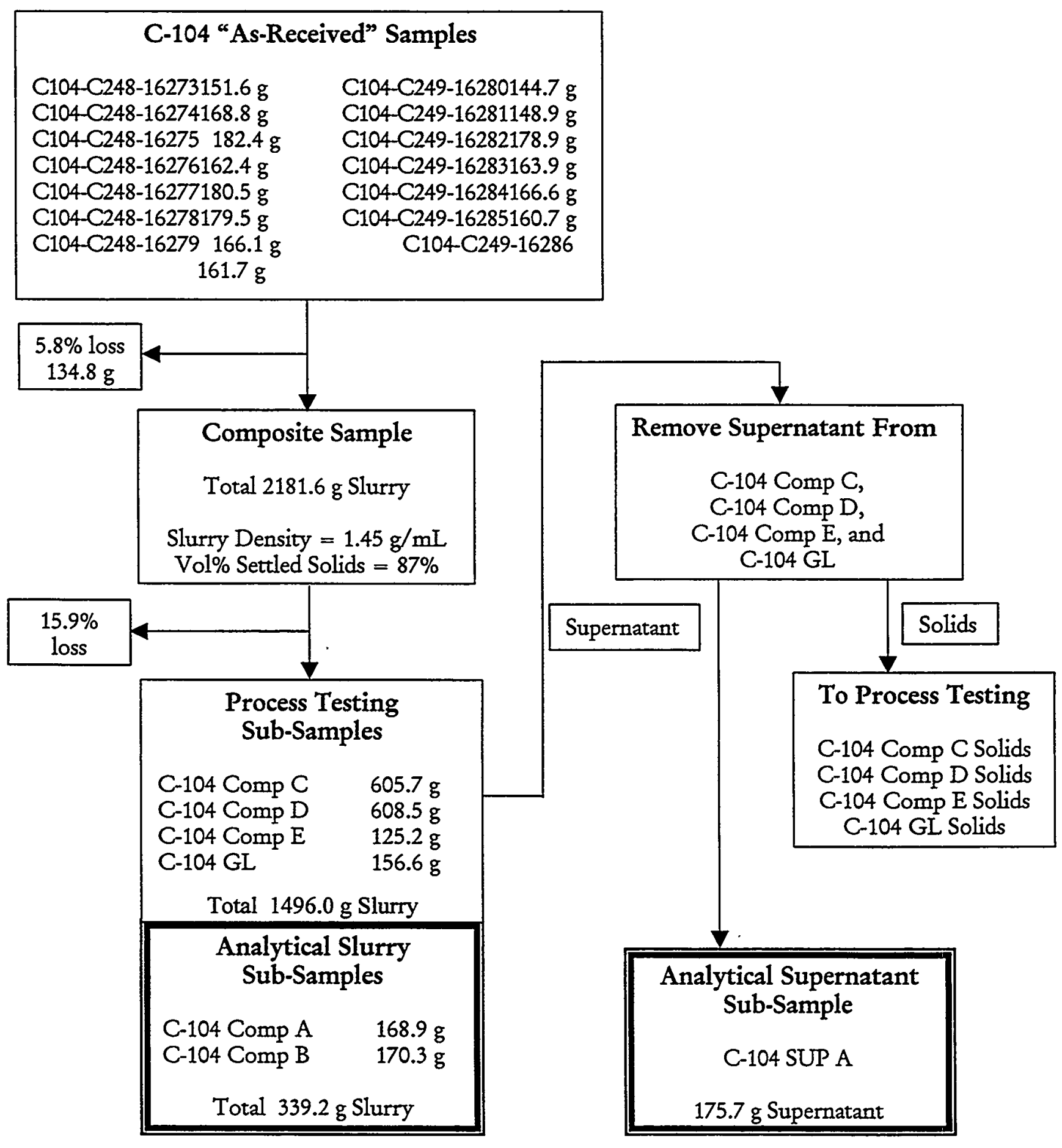

Figure 1.1. Compositing and Sub-sampling for C-104 As-Received Analytical Samples 


\subsection{Sample Processing}

The inorganic and radiochemical analysis sample processing instructions were provided to the SAL via special instruction included with Analytical Service Request (ASR) number 5729 and the total dissolved solids (TDS), weight percent solids, and phase separation instructions were provided via Test Plan BNFL-TP-29953-080. The inorganic and radiochemical sub-sampling was performed after all organic sub-sampling had been completed, to minimize loss of volatile organic compounds.

\subsection{Total Dissolved Solids and Weight Percent Solids}

Duplicate aliquots (approximately $3 \mathrm{~g}$ each) were withdrawn from C-104 Comp A for determination of centrifuged weight percent solids (wt\% solids) of the composite slurry, TDS of the supernatant, and wt\% solids (dry) of the centrifuged solids phase. The aliquots were withdrawn from the C-104 Comp A jar while the contents were mechanically stirred providing homogeneous sub-samples. The aliquots were placed in volume-graduated centrifuge tubes and centrifuged at $1100 \mathrm{rpm}$ for about one hour. Following centrifuging, the volume percent solids and wt\% solids (wet) were determined on the slurry. Following phase separation by decanting, the wt\% solids (dry) of the centrifuged solids fraction and the TDS of the supernatant fraction were determined. Table 2.1 provides the results for the TDS and percent solids.

Table 2.1. Slurry Vol\% and Wt\% Solids, TDS, and Centrifuged Solids Wt\% Solids

\begin{tabular}{||l|c|c|c|c||}
\hline \multirow{2}{*}{ Sample ID } & \multicolumn{2}{|c|}{ Sluriy } & Süperiatant & Centrifúged Solids \\
\cline { 2 - 5 } & $\begin{array}{c}\text { Volume \% } \\
\text { Centrifuged } \\
\text { Solids (Wet) }\end{array}$ & $\begin{array}{c}\text { Weight \% } \\
\text { Centrifuged } \\
\text { Solids (Wet) }\end{array}$ & TDS (\%) & $\begin{array}{c}\text { Weight \% } \\
\text { Solids (Dry) }\end{array}$ \\
\hline \hline C-104 Comp A & 63 & 81.0 & 16.7 & 58.8 \\
\hline $\begin{array}{l}\text { C-104 Comp A } \\
\text { Dup }\end{array}$ & 60 & 83.0 & 16.8 & 59.4 \\
\hline
\end{tabular}

Based on the Slurry wt $\%$ wet centrifuged solids and the Centrifuged Solids $w t \%$ dry solids, the Slurry wt\% solids (dry) averages $51.5 \%$, of the as-received material.

\subsection{Phase Separation}

The contents of C-104 Comp A and C-104 Comp B were separated into solids and supernatant phases so that inorganic and radiochemical analyses could be performed on each phase. The phase separation was performed by centrifuging and decanting the supernatant. Each sample was centrifuged in its original jar at $1100 \mathrm{rpm}$ for one hour, and the supernatant decanted and combined with C-104 SUP A. The wet centrifuged solids remained in the original jars. Following sub-sampling and processing for organic analysis, sub-samples of the supernatant and centrifuged solids were processed for inorganic and radiochemical analysis. Following phase separation, the RPL internal tracking number 00-1360 was used to identify the supernatant sample and 00-1361 was used to identify the centrifuged solids sample. 


\subsection{Supernatant Density Measurements}

Due to the viscous nature of the as-received supernatants, all supernatant samples were processed by weight (i.e., most analytical sub-samples were aliquotted by weight instead of by volume). The density of the supernatant was determined by weighing $5-\mathrm{mL}$ aliquots delivered from a calibrated 5-mL pipet. The delivery volume of the pipet was determined by five replicate measurements of water density corrected for the ambient temperature. The resulting average density was used to convert supernatant results from a per mass to a per volume basis, as necessary. Table 2.2 provides the density results obtained on the $C$ 104 supernatant following phase separation.

Table 2.2. Density Results for C-104 Supernatant Composite

\begin{tabular}{|l|l|c|c|}
\hline RPL Number & Sample ID & $\begin{array}{c}\text { Density } \\
(\mathrm{g} / \mathbf{m} \mathbf{m})\end{array}$ & $\begin{array}{c}\text { Average:Density } \\
(\mathrm{g} / \mathrm{mL})\end{array}$ \\
\hline $00-01360$ & Supernatant & 1.163 & \multirow{2}{*}{1.161} \\
\cline { 2 - 3 } & Supernatant Duplicate & 1.160 & \multirow{2}{*}{} \\
\cline { 2 - 3 } & Supernatant Triplicate & 1.160 & \\
\hline
\end{tabular}

\subsection{Initial Preparation of Supernatants and Solids}

The processing of the C-104 composite supernatant and solids and distribution of the processed samples are detailed in Figure 2.1. All processing was conducted in the SAL.

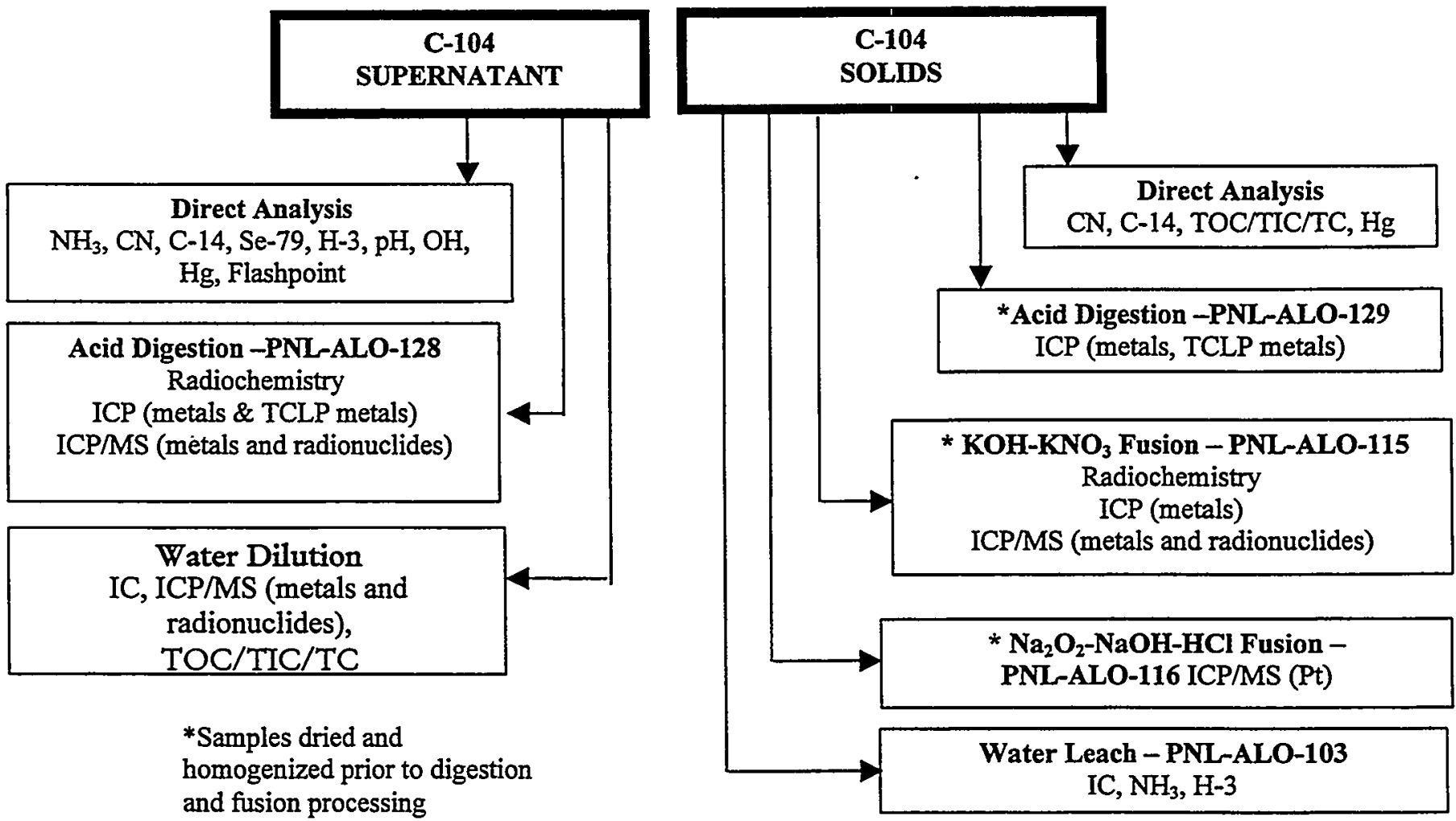

Figure 2.1. Flow Diagram for Analytical Preparation of Supernatant and Solids 
The C-104 composite supernatant was prepared by acid digestion per procedure PNL-ALO-128 $\left(\mathrm{HNO}_{3}-\mathrm{HCl}\right.$ acid digestion) for metals analysis by inductively coupled plasma spectrometry (ICP), radiochemical analysis, and metal and radionuclides analysis by inductively coupled plasma - mass spectrometry (ICP/MS). The digested solutions had no visible residue or precipitate. All other analyses were performed directly on the supernatant or on water dilutions of the supernatant.

For the centrifuged solids, three preparative methods, PNL-ALO-129 $\left(\mathrm{HNO}_{3}-\mathrm{HCl}\right.$ acid digestion), PNL-ALO-115 (KOH-KNO ${ }_{3}$ fusion), PNL-ALO-116 $\left(\mathrm{Na}_{2} \mathrm{O}_{2}-\mathrm{NaOH}-\mathrm{NaCl}\right.$ fusion), were performed on the dried centrifuged solids to provide analysis solutions for analytes of interest: The different preparative techniques were utilized in order to obtain optimal analyte information. For example, some analytes will go into solution only when fused, such as $\mathrm{Si}$ and refractory metals. Other analytes, such as $\mathrm{Na}$ and $\mathrm{K}$, are better analyzed from an acid digestion where the fusion flux is absent. The wet centrifuged samples were initially dried to provide more consistent sub-sampling for the small aliquots taken for dissolution. The acid digestion and $\mathrm{KOH}-\mathrm{KNO}_{3}$ fusion preparations were analyzed for metals by ICP; the $\mathrm{KOH}-\mathrm{KNO}_{3}$ fusion preparations were used for radiochemical analyses and for metals and radionuclides by ICP/MS. The $\mathrm{Na}_{2} \mathrm{O}_{2}-\mathrm{NaOH}-\mathrm{NaCl}$ fusion was prepared specifically to obtain solutions for analysis of platinum by ICP/MS. All acid digestion and fusion preparations produced clear solutions with no visible residue, except for a few of the samples prepared by the $\mathrm{Na}_{2} \mathrm{O}_{2}-\mathrm{NaOH}-\mathrm{NaCl}$ fusion, which demonstrated a slight cloudiness. The wt\% dry solids from the analysis of the wet centrifuged solids were used to adjust the measured results to the reported 'per gram wet centrifuged solids' basis.

Aliquots of wet centrifuged solids were diluted/leached per PNL-ALO-103. Aliquots of the water leach were analyzed for soluble anions by ion chromatography (following filtering), ammonia by ion specific electrode (ISE), and tritium by liquid scintillation counting.

Carbon (total carbon-TC, total inorganic-TIC, and total organic-TOC), mercury, and cyanide analyses were performed directly on the wet centrifuged solid.

Sub-samples from the processing steps were delivered to specific laboratories for analysis under COC. 


\subsection{Analysis Results for Analytes of Interest}

Tables 3.1 through 3.5 provide the results for all inorganic and radiochemical analyses performed on the C-104 as-received composite. Results for samples and duplicates, as well as processing blanks (PB), are reported. Although the supernatants were processed by weight, the density of the supernatants has been used to provide the results in $\mu \mathrm{g} / \mathrm{mL}$ or $\mu \mathrm{Ci} / \mathrm{mL}$, as appropriate. Solids are reported in $\mu \mathrm{g} / \mathrm{g}$ or $\mu \mathrm{Ci} / \mathrm{g}$, as appropriate, where $\mathrm{g}$ represents mass of centrifuged wet solids. These results may be converted to a dry weight basis using the wt\% solids given in Table 2.1. The reported results have not been corrected for contributions present in the process blank.

The ICP/MS results are reported in both $\mu \mathrm{g} / \mathrm{mL}$ and $\mu \mathrm{Ci} / \mathrm{mL}$ for supernatants and $\mu \mathrm{g} / \mathrm{g}$ and $\mu \mathrm{Ci} / \mathrm{g}$ for solids (where activity units are relevant). The results are provided based on both curies and mass so that a direct comparison can be made against the minimum reportable quantity (MRQ) specifications. The radionuclides measured by ICP/MS have supernatant MRQs specified in $\mu \mathrm{Ci} / \mathrm{mL}$ and solids $\mathrm{MRQs}$ specified in $\mu \mathrm{g} / \mathrm{g}$.

To evaluate the concentrations of analytes of interest in the as-received slurry material, slurry results have been calculated from the concentrations measured in the supernatant and in the wet centrifuged solids and the weight fractions of each phase. To provide a conservative total slurry concentration, the highest measured concentration from either the sample or the duplicate, from either preparative technique (where applicable), for each phase is used in the calculation. Where no analyte concentration is measured (i.e., results are less than MDL), the lowest MDL is used in the calculation. The "maximum" slurry concentration is calculated by Equation (1).

$$
C_{m}=\left(\left(C_{l} / D_{1}\right) * W_{1}\right)+\left(C_{s} * W_{s}\right)
$$

Where: $\mathrm{C}_{\mathrm{m}} \quad=$ Maximum slurry concentration in $\mu \mathrm{g} / \mathrm{g}$ or $\mu \mathrm{Ci} / \mathrm{g}$

$\mathrm{C}_{\mathrm{l}}=$ Analyte concentration in supernatant in $\mu \mathrm{g} / \mathrm{mL}$ or $\mu \mathrm{Ci} / \mathrm{mL}$

$\mathrm{D}_{\mathrm{l}} \quad=$ Density of supernatant in $\mathrm{g} / \mathrm{mL}$ (i.e., $1.161 \mathrm{~g} / \mathrm{mL}$, Table 2.2)

$W_{1}=$ Weight fraction of supernatant (i.e., 0.18, Table 2.1)

$\mathrm{C}_{s}=$ Analyte concentration in solids in $\mu \mathrm{g} / \mathrm{g}$ or $\mu \mathrm{Ci} / \mathrm{g}$

$\mathrm{W}_{\mathrm{s}}=$ Weight fraction of wet centrifuged solids (i.e., 0.82 , Table 2.1) 
Table 3.1. C-104 As-Received --- ICP Metals Results

\begin{tabular}{|c|c|c|c|c|c|c|c|c|c|c|c|c|c|}
\hline \multirow{4}{*}{\begin{tabular}{|r|} 
Tank Material \\
Matrix \\
Dissolution \\
LabiD
\end{tabular}} & \multirow{2}{*}{\multicolumn{4}{|c|}{ Snpernatint" }} & \multicolumn{8}{|c|}{ C-104 As-Rècétived ${ }^{(1)}$} & \multirow{5}{*}{$\begin{array}{l}\text { Max } \\
\text { Slurry } \\
\text { Conc. } \\
\mu \mathrm{g} / \mathrm{g}\end{array}$} \\
\hline & & & & & \multicolumn{8}{|c|}{ Centrifuged Wet Solids } & \\
\hline & \multicolumn{4}{|c|}{$\frac{\text { Supernatant }}{\text { Acid Digest }}$} & \multicolumn{4}{|c|}{ KOA-KNO Ińsion } & \multicolumn{4}{|c|}{ Acid Digést } & \\
\hline & $\begin{array}{l}00-1360 \\
: \mathbf{P B}\end{array}$ & $\begin{array}{l}00-1360 \\
\text { Sample }\end{array}$ & \begin{tabular}{|c|} 
00-1360-d \\
Dup.
\end{tabular} & \multirow{2}{*}{$\begin{array}{r}\begin{array}{r}(2) \\
\text { RPD } \\
(\%)\end{array} \\
\end{array}$} & $\begin{array}{c}00-1361 \\
: \mathrm{PB}\end{array}$ & $\begin{array}{l}00-1361 \\
\text { Sample }\end{array}$ & $\begin{array}{c}00-1361-d \\
\text { Dup. }\end{array}$ & \multirow{2}{*}{$\mid \begin{array}{c}(2) \\
R P D \\
(\%)\end{array}$} & $\begin{array}{c}00-1361 \\
\text { PB }\end{array}$ & $\begin{array}{l}00-1361 \\
\text { Sample }\end{array}$ & {$\left[\begin{array}{c}00-1361-d \\
\text { Dup. }\end{array}\right.$} & \multirow{2}{*}{$\mid \begin{array}{c}(2) \\
\text { RPD } \\
(\%)\end{array}$} & \\
\hline Units & $\mu \mathrm{g} / \mathrm{mL}$ & $\mu \hat{g} / \hat{m} \mathbf{L}$ & $\mu \mathrm{g} / \mathrm{mL}$ & & $\mu \mathrm{g} / \mathrm{g}$ & $\mu g / g$ & $\mu g / g$ & & jig/g & $\mu g / g$ & $\mu \mathrm{g} / \mathrm{g}$ & & \\
\hline BNFL-List & & $\therefore$ & 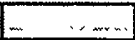 & $\therefore$ & $2 \ldots$ & $\sim$ & $\therefore$ & 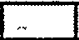 & & $\therefore$ & & & \\
\hline Ag & $<0.1$ & [1.4] & [1.6] & & $<13$ & 210 & 158 & 28 & $<0.8$ & [54] & [46] & & 170 \\
\hline Al & 5.3 & 418 & 449 & 7 & [51] & 63,800 & 68,600 & 7 & 33 & 72,100 & 73,300 & 2 & 60,200 \\
\hline As & $<1.2$ & $<12$ & $<13$ & & $<130$ & $<151$ & $<114$ & & $<8$ & $<71$ & $<73$ & & $<95$ \\
\hline $\mathbf{B}$ & 12.4 & 205 & 237 & 14 & $<26$ & $<30$ & $<23$ & & 76 & [71] & {$[71]$} & & 95 \\
\hline $\mathbf{B a}$ & {$[0.08]$} & $<0.5$ & {$[0.5]$} & & $<5$ & 79 & 83 & 4 & {$[0.5]$} & 85 & 83 & 1 & 69 \\
\hline $\mathrm{Be}$ & $<0.05$ & $<0.5$ & $<0.5$ & & $<5$ & [17] & [18] & & $<0.3$ & [19] & {$[19]$} & & 16 \\
\hline $\mathbf{B i}$ & $<0.5$ & $<4.9$ & $<5.1$ & & $<52$ & $<61$ & $<46$ & & $<3$ & $<29$ & $<29$ & & $<24$ \\
\hline $\mathrm{Ca}$ & $<1.2$ & [31] & [28] & & $<130$ & 2,020 & 2,020 & 0 & $<8$ & 2,140 & 2,140 & 0 & 1,760 \\
\hline $\mathrm{Cd}$ & $<0.1$ & 9.0 & 9.8 & 9 & $<8$ & 388 & 393 & 1 & $<0.5$ & 411 & 420 & 2 & 584 \\
\hline $\mathrm{Co}$ & $<0.2$ & $<2.5$ & $<2.5$ & & $<26$ & $<30$ & $<23$ & & $<2$ & $<14$ & $<15$ & & $<13$ \\
\hline $\mathrm{Cr}$ & $<0.1$ & 55.4 & 61 & 10 & $<10$ & 721 & 733 & 2 & $<0.6$ & 709 & 709 & 0 & 610 \\
\hline $\mathrm{Cu}$ & $<0.1$ & [6.9] & [7.7] & & $<13$ & {$[106]$} & 115 & & $<0.8$ & 99 & 96 & 2 & 96 \\
\hline $\mathrm{Fe}$ & {$[0.18]$} & 17.7 & 18.4 & 4 & 230 & 19,500 & 20,000 & 2 & {$[1.1]$} & 19,400 & 18,900 & 2 & 16,400 \\
\hline $\mathbf{K}$ & $<9.9$ & {$[620]$} & {$[690]$} & & $\mathrm{n} / \mathrm{a}$ & $\mathrm{n} / \mathrm{a}$ & $\mathrm{n} / \mathrm{a}$ & & $<61$ & $<571$ & $<588$ & & 575 \\
\hline $\mathbf{L i}$ & $<0.1$ & 21.0 & 22.9 & 9 & $<16$ & 205 & 207 & 1 & $<0.9$ & 249 & 252 & 1 & 210 \\
\hline $\mathbf{M g}$ & $<0.5$ & [11] & [12] & & $<52$ & [372] & [325] & & $<3$ & [266] & [272] & & 307 \\
\hline $\mathbf{M n}$ & $<0.2$ & {$[6.8]$} & {$[7.0]$} & & [71] & 4,430 & 4,490 & 1 & $<2$ & 4,830 & 4,850 & 0 & 3,980 \\
\hline Mo & $<0.2$ & [7.9] & {$[8.8]$} & & $<26$ & $<30$ & $<23$ & & $<2$ & $<14$ & $<15$ & & 13 \\
\hline $\mathrm{Na}$ & 19.2 & 67,700 & 75,700 & 11 & [709] & 70,900 & 72,700 & 2 & 119 & 82,100 & 81,600 & 1 & 79,100 \\
\hline $\mathbf{N i}$ & {$[0.35]$} & 121 & 135 & 11 & $\mathrm{n} / \mathrm{a}$ & $\mathrm{n} / \mathrm{a}$ & $\mathrm{n} / \mathrm{a}$ & & [2.2] & 1,320 & 1,320 & 0 & 1,110 \\
\hline $\mathbf{P}$ & $<0.5$ & 1,070 & 1,180 & 10 & $<52$ & 1,630 & 928 & 55 & $<3$ & [89] & [65] & & 1,520 \\
\hline $\mathrm{Pb}$ & $<0.5$ & $<4.9$ & $<5.1$ & & $<52$ & 804 & 733 & 9 & $<3$ & 709 & 697 & 2 & 660 \\
\hline Pd & $<3.7$ & $<37$ & $<38$ & & $<391$ & $<454$ & $<343$ & & $<23$ & $<214$ & $<220$ & & $<180$ \\
\hline $\mathbf{R h}$ & $<1.5$ & $<15$ & $<15$ & & $<156$ & $<182$ & $<137$ & & $<9$ & $<86$ & $<88$ & & $<73$ \\
\hline $\mathbf{S b}$ & $<2.5$ & $<25$ & $<25$ & & $<261$ & $<303$ & $<229$ & & $<15$ & $<143$ & $<147$ & & $<120$ \\
\hline $\mathrm{Se}$ & $<1.2$ & $<12$ & $<13$ & & $<130$ & $<151$ & $<114$ & & $<8$ & $<71$ & $<73$ & & $<60$ \\
\hline $\mathbf{S i}$ & 26.4 & 1,880 & 2,110 & 12 & $<261$ & 6,030 & 5,820 & 3 & 163 & [768] & 1,660 & & 5,270 \\
\hline $\mathbf{S n}$ & $<7.4$ & $<74$ & $<76$ & & $<782$ & $<908$ & $<686$ & & $<46$ & [585] & [585] & & 491 \\
\hline $\mathbf{T 1}$ & $<2.5$ & $<25$ & $<25$ & & $<261$ & $<303$ & $<229$ & & $<15$ & $<143$ & $<147$ & & $<120$ \\
\hline $\mathbf{U}$ & $<9.9$ & $<99$ & $<101$ & & $<1040$ & 21,300 & 21,300 & 0 & $<61$ & 23,600 & 23,600 & 0 & 19,400 \\
\hline $\mathrm{U}$ (KinPhos) ${ }^{(\mathfrak{l})}$ & 0.005 & 29 & 30 & 5 & 0.54 & 19,800 & 19,200 & 3 & $\mathrm{n} / \mathrm{m}$ & $n / m$ & $\mathrm{n} / \mathrm{m}$ & & 16,200 \\
\hline U (ICP-MS) $)^{(3)}$ & 0.013 & 31.6 & 35.8 & 12 & $<84$ & 21,400 & 21,000 & 2 & $\mathrm{n} / \mathrm{m}$ & $\mathrm{n} / \mathrm{m}$ & $\mathrm{n} / \mathrm{m}$ & & 17,600 \\
\hline $\mathbf{V}$ & $<0.2$ & $<2.5$ & $<2.5$ & & $<26$ & [31] & $<23$ & & $<2$ & $<14$ & $<15$ & & $<12$ \\
\hline $\mathbf{W}$ & $<9.9$ & $<99$ & $<101$ & & $<1040$ & $<1210$ & $<915$ & & $<61$ & $<571$ & $<588$ & & $<480$ \\
\hline $\mathbf{Y}$ & $<0.2$ & $<2.5$ & $<2.5$ & & $<26$ & $<30$ & $<23$ & & $<2$ & {$[17]$} & {$[17]$} & & 14 \\
\hline $\mathbf{Z n}$ & $<0.2$ & $<2.5$ & $<2.5$ & & $<26$ & {$[100]$} & [95] & &.$<2$ & [95] & [95] & & 83 \\
\hline $\mathbf{Z r}$ & $<0.2$ & [20] & [20] & & $<26$ & 23,600 & 24,000 & 1 & $<2$ & 17,200 & 17,500 & 2 & 19,700 \\
\hline \multicolumn{14}{|c|}{ Other Analytes Detected } \\
\hline $\mathrm{Ce}$ & $<1.0$ & $<9.9$ & $<10$ & & $<104$ & [266] & {$[177]$} & & $<6$ & {$[154]$} & [136] & & 220 \\
\hline $\mathbf{L a}$ & $<0.2$ & $<2.5$ & $<2.5$ & & $<26$ & [71] & [59] & & $<2$ & [65] & [59] & & 59 \\
\hline Nd & $<0.5$ & $<4.9$ & $<5.1$ & & $<52$ & [183] & [130] & & $<3$ & [136] & [136] & & 151 \\
\hline Sr & $<0.1$ & $<0.7$ & $<0.8$ & & $<8$ & [38] & [41] & & $<0.5$ & {$[40]$} & [40] & & 34 \\
\hline Th & $<5.0$ & $<49$ & $<51$ & & $<521$ & 26,100 & 27,300 & 5 & $<31$ & 30,600 & 30,900 & 1 & 25,400 \\
\hline $\mathbf{T i}$ & $<0.1$ & $<1.2$ & $<1.3$ & & $<13$ & [95] & [95] & & $<0.8$ & {$[58]$} & [57] & & 78 \\
\hline $\begin{array}{l}\text { (1) Overall erro } \\
\text { (i.e., 10-tim } \\
\text { (2) RPD only c } \\
\text { (3) U (KinPhos }\end{array}$ & $\begin{array}{l}\mathrm{r} \text { for reporte } \\
\text { es MDL list } \\
\text { alculated wh }\end{array}$ & $\begin{array}{l}\text { d results is } \\
\text { ed in Table } \\
\text { en both sar }\end{array}$ & $\begin{array}{l}\text { estimated to } \\
6.1 \text { ) and er } \\
\text { mple and du } \\
\text { cence; } U \text { (IC }\end{array}$ & $\begin{array}{l}\text { o be wit } \\
\text { ror is a } \\
\text { uplicate }\end{array}$ & $\begin{array}{l}\text { in } \pm 15 \% \text { ( } 2 \\
\text { ticipated to } \\
\text { xceed estin }\end{array}$ & $\begin{array}{l}-\sigma ; \text { howeve } \\
\text { be greater } \\
\text { nated quan } \\
\text { ely-couple }\end{array}$ & $\begin{array}{l}\text { er results in } \\
\text { than } \pm 15 \% \\
\text { ititation leve } \\
\text { ed plasma m }\end{array}$ & $\begin{array}{l}\text { bracke } \\
\text { el. }\end{array}$ & "[ []" are 1 & ess than the & e estimated c & quantite & tion level \\
\hline
\end{tabular}


Table 3.3. C-104 As-Received --- ICP/MS Results

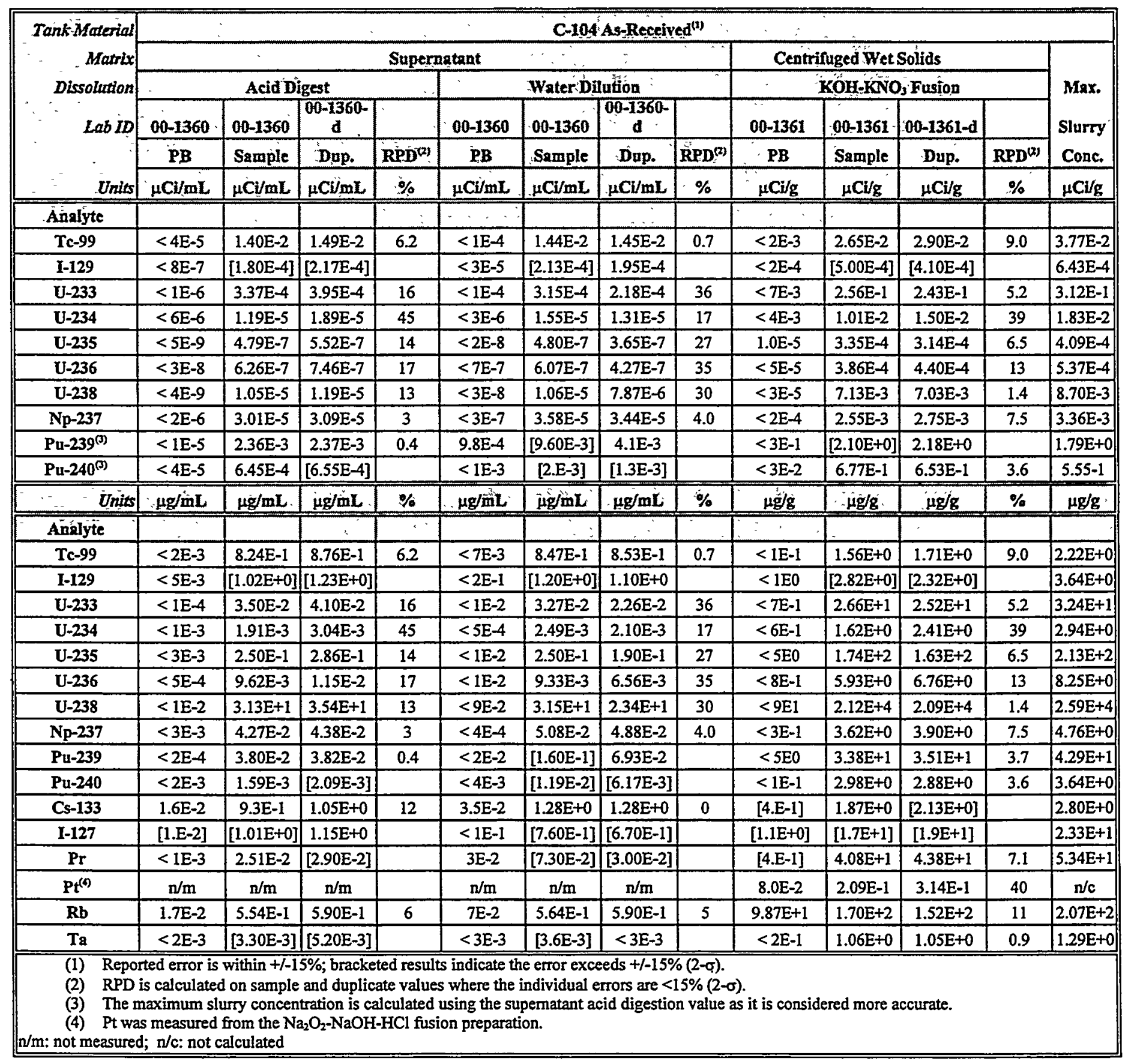


Table 3.4. C-104 As-Received Cs and U Mass Abundance Ratios

\begin{tabular}{|c|c|c|c|c|c|c|}
\hline \multirow{4}{*}{$\begin{array}{r}\text { Tank Material } \\
\text { Matrix } \\
\text { Dissolution } \\
\text { Lab iD }\end{array}$} & \multicolumn{6}{|c|}{ C-104 As-Received } \\
\hline & \multicolumn{3}{|c|}{ Superíntant } & \multicolumn{3}{|c|}{ Centrifuged Wet Sólidus } \\
\hline & \multicolumn{3}{|c|}{ Acid-Digestion } & \multicolumn{3}{|c|}{ KOḦ-KNO ${ }_{3}$ Fusion } \\
\hline & $\begin{array}{l}00-1360 \\
\text { Sample } \\
\end{array}$ & $\begin{array}{c}00-1360-d \\
\text { Dup. }\end{array}$ & RPD & $\begin{array}{l}\text { 00-1361 } \\
\text { Sample }\end{array}$ & $\begin{array}{l}\text { C0-1361-d } \\
\text { Dup. }\end{array}$ & RPD \\
\hline Units & \multicolumn{2}{|c|}{$\%$ mass abundance. } & $\%$ & \multicolumn{2}{|c|}{$\%$ mass abundance. } & $\%$ \\
\hline \multicolumn{7}{|l|}{ Analyte } \\
\hline Cs-133 & $5.53 \mathrm{E}+1$ & $5.59 \mathrm{E}+1$ & 1.1 & $6.94 \mathrm{E}+1$ & $7.22 \mathrm{E}+1$ & 4.0 \\
\hline Cs-135 & $1.97 \mathrm{E}+1$ & $1.93 \mathrm{E}+1$ & 2.1 & $1.33 \mathrm{E}+1$ & $1.19 \mathrm{E}+1$ & 11 \\
\hline Cs-137 & $2.50 \mathrm{E}+1$ & $2.48 \mathrm{E}+1$ & 0.8 & $1.74 \mathrm{E}+1$ & $1.60 \mathrm{E}+1$ & 8.4 \\
\hline $\mathrm{U}-233$ & $1.11 E-1$ & $1.15 \mathrm{E}-1$ & 3.5 & $1.03 \mathrm{E}-1$ & $9.57 \mathrm{E}-2$ & 7.3 \\
\hline $\mathrm{U}-234$ & $6.07 \mathrm{E}-3$ & $8.50 \mathrm{E}-3$ & 33 & $7.83 \mathrm{E}-3$ & 8.91E-3 & 13 \\
\hline U-235 & $7.04 \mathrm{E}-1$ & 7.17E-1 & 1.8 & $6.98 \mathrm{E}-1$ & $7.15 \mathrm{E}-1$ & 2.4 \\
\hline U-236 & $3.05 E-2$ & $3.22 \mathrm{E}-2$ & 5.4 & $2.93 \mathrm{E}-2$ & $2.78 \mathrm{E}-2$ & 5.3 \\
\hline $\mathrm{U}-238$ & $9.91 \mathrm{E}+1$ & $9.91 E+1$ & 0.020 & $9.92 \mathrm{E}+1$ & $9.92 E+1$ & 0.010 \\
\hline
\end{tabular}


Table 3.5. C-104 As-Received --- Other Results

\begin{tabular}{|c|c|c|c|c|c|c|c|c|c|c|c|}
\hline \multirow{3}{*}{$\begin{array}{r}\text { Tank Material } \\
\text { Matrix } \\
\text { Lab iD }\end{array}$} & \multicolumn{11}{|c|}{ C-104 As=Received ${ }^{9}$} \\
\hline & \multicolumn{5}{|c|}{ Sùpernating } & \multicolumn{5}{|c|}{ Centrifuged Wet Solids } & \multirow{3}{*}{$\begin{array}{l}\text { Max. } \\
\text { Slurry } \\
\text { Conc. } \\
\mu \mathrm{g} / \mathrm{g}\end{array}$} \\
\hline & \multirow{2}{*}{$\begin{array}{l}\text { Type of } \\
\text { Prep }\end{array}$} & $\begin{array}{c}00-1360 \\
\text { PB }\end{array}$ & $\begin{array}{l}00-1360 \\
\text { Sempie }\end{array}$ & \begin{tabular}{|c|}
$00-1360-d$ \\
Dup.
\end{tabular} & \multirow{2}{*}{$\begin{array}{c}(2) \\
\text { RPिD } \\
(\%)\end{array}$} & \multirow{2}{*}{$\begin{array}{l}\text { Type of } \\
\text { Prep }\end{array}$} & $\begin{array}{c}00-1361 \\
\text { PB }\end{array}$ & $\begin{array}{l}00-1361 \\
\text { Sample }\end{array}$ & \begin{tabular}{|c|}
$00-1361-$ \\
Dup.
\end{tabular} & $\begin{array}{c}\text { (2) } \\
\text { RPD }\end{array}$ & \\
\hline Units & & 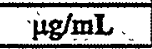 & Hg/mL & $\mu \mathrm{g} / \mathrm{mL}$ & & & $\mu g / g$ & $\mu g / g$ & $\mathrm{fg} / \mathrm{g}$ & $(\%)$ & \\
\hline Analyte & $\therefore$ & & $\therefore$ & $\therefore$ & & & \%. & & & nas & . \\
\hline TIC & Persulfate & $\mathrm{n} / \mathrm{a}$ & 8,330 & 8270 & 1 & Persulfate & $n / a$ & 4,200 & 3,800 & 10 & 4,730 \\
\hline TOC & Persulfate & $n / a$ & 6,500 & 6,720 & 3 & Persulfate & $n / a$ & 10,300 & 7,700 & 29 & 9,490 \\
\hline TC (sum) & Persulfate & $\mathrm{n} / \mathrm{a}$ & 14,800 & 15,000 & 1 & Persulfate & $\mathrm{n} / \mathrm{a}$ & 14,500 & 11,500 & 23 & 14,200 \\
\hline TC & Furnace & $\mathrm{n} / \mathrm{a}$ & 14,900 & 14,100 & 6 & Furnace & $\mathrm{n} / \mathrm{a}$ & 24,800 & 22,100 & 12 & 22,600 \\
\hline Fluoride & Dir.Jil. & $\mathrm{n} / \mathrm{a}$ & $9,710^{(3)}$ & $9,500^{(3)}$ & 2 & Water & $<24$ & $46,200^{(2)}$ & $48,300^{(2)}$ & 2 & 41,100 \\
\hline Chloride & Dir./Dil. & $\mathrm{n} / \mathbf{a}$ & 790 & 720 & 9 & Water & [26] & 250 & 220 & 12 & 330 \\
\hline Nitrite & Dir./Dil. & $\mathrm{n} / \mathrm{a}$ & 34,200 & 29,100 & 16 & Water & $<48$ & 10,500 & 10,500 & 0 & 13,900 \\
\hline Bromide & Dir/Dil. & $\mathrm{n} / \mathrm{a}$ & 3,270 & 2,920 & 11 & Water & $<24$ & 1,020 & 1,020 & 0 & 1,350 \\
\hline Nitrate & Dir./Dil. & $n / a$ & 17,600 & 16,100 & 9 & Water & $<48$ & 5,630 & 5,590 & 1 & 7,350 \\
\hline Phosphate & Dir./Dil. & $\mathrm{n} / \mathrm{a}$ & 3,040 & 2,640 & 14 & Water & $<48$ & 9,650 & 2,600 & 115 & 8,400 \\
\hline Sulfate & Dir./Dil. & $\mathrm{n} / \mathrm{a}$ & 3,870 & 3,410 & 13 & Water & $<48$ & 1,430 & 1,410 & 1 & 1,800 \\
\hline Oxalate & Dir./Dil. & $\mathrm{n} / \mathrm{a}$ & 3,590 & 3260 & 10 & Water & $<48$ & 7,690 & 7,440 & 3 & 6,900 \\
\hline Mercury & Acid Digest & 0.014 & 0.722 & 0.602 & 20 & Acid Digest & $<0.05$ & 41.1 & 40.2 & 2 & 34 \\
\hline Ammonia & Dir./Dil. & $\mathrm{n} / \mathrm{a}$ & 17.4 & 19.2 & 10 & Water & 1.05 & 3.38 & 3.09 & 9 & 5.7 \\
\hline Cyanide (total) & Distillation & $<0.01$ & 7.4 & 8.5 & 14 & Distillation & $<0.04$ & 11.4 & 13.8 & 19 & 13 \\
\hline Unitts & & .5 & ${ }^{\circ} \mathrm{F}$ & $\mathbf{F}$ & & & & & & & \\
\hline Flashpoint & Direct & $\mathrm{n} / \mathrm{a}$ & $220^{(4)}$ & $218^{(4)}$ & & & & & & & \\
\hline Units & & mmöle/mL & mimole/mL & mmole/mL & & & & & & & \\
\hline Hydroxide & Dir./Dil. & $<0.01^{(s)}$ & 0.81 & 0.82 & 0.4 & & & & & & \\
\hline Units & & pH & pH & pH & & & & & & & \\
\hline $\mathbf{p H}$ & Direct & $\mathrm{n} / \mathrm{m}$ & 12.1 & 12.1 & 0 & & & & & & \\
\hline \multicolumn{12}{|c|}{$\begin{array}{l}\text { (1) Overall error for reported results is estimated to be within } \pm 15 \%(2-\sigma) \text {; bracketed results indicate the error exceeds }+/-15 \%(2-\sigma) \text {. } \\
\text { (2) RPD only calculated when sample and duplicate results above threshold for method's RPD calculation (calculated prior to rounding). }\end{array}$} \\
\hline \multicolumn{12}{|c|}{$\begin{array}{l}\text { (3) IC system quantifies F based on retention time; however, fluoride, formate and acetate can not be resolved. Reported value reflects } \\
\text { contribution formate and/or acetate. } \\
\text { (4) Flashpoint is attributed to a "false flash" due to water volatilizing to steam. } \\
\text { (5) No titration inflection point detected; free hydroxide estimated at }<0.01 \mathrm{mmole} / \mathrm{mL} \text {. } \\
\text { dir/dil.= direct or dilution; } \mathrm{n} / \mathrm{a}=\text { not applicable; } \mathrm{n} / \mathrm{m}=\text { not measured due to applicability of method }\end{array}$} \\
\hline
\end{tabular}




\subsection{TCLP Metals Analysis and Evaluation}

The TCLP, SW-846 Method 1311, was not performed on C-104 waste materials for toxic metals. The estimated TCLP metals concentrations are calculated from 1) the concentrations of the supernatant TCLP metals, 2) the concentrations from acid digestion of the solids TCLP metal (assuming all metals would be leached $100 \%$ using Method 1311), 3) the density of the supernatant, and 4) the centrifuged wet wt $\%$ solids. The centrifuged wet wt $\%$ solids are used instead of the filtered wet wt $\%$ solids from Method 1311; however, the two methods for determining the wet wt\% solids are considered reasonably comparable for this exercise. The concentrations of the TCLP metals are estimated by assuming that the supernatants and solids are analyzed separately and combined mathematically per Method 1311 . The estimated concentrations of the TCLP metals in the as-received tank waste materials, assuming a $100 \mathrm{~g}$ initial sample size for processing, is provided in Equation 2:

$$
\mathrm{C}=\left[\left(\mathrm{L} *\left(\mathrm{~V}_{1} / \mathrm{D}_{1}\right)\right)+\left(\mathrm{S} * \mathrm{~V}_{2}\right)\right] /\left[\left(\mathrm{V}_{1} / \mathrm{D}_{1}\right)+\left(\mathrm{V}_{2} * \mathrm{~F} / \mathrm{D}_{2}\right)\right]
$$

Where: $\quad \mathrm{C}=$ Waste material TCLP metal concentration in $\mu \mathrm{g} / \mathrm{mL}$

$\mathrm{L}=$ average supernatant TCLP metal concentration in $\mu \mathrm{g} / \mathrm{mL}$

$\mathrm{S}=$ average solids TCLP metal concentration in $\mu \mathrm{g} / \mathrm{g}$

$\mathrm{D}_{1}=$ density of supernatant in $\mathrm{g} / \mathrm{mL}(1.161 \mathrm{~g} / \mathrm{mL})$

$\mathrm{D}_{2}=1$, approximate density in $\mathrm{g} / \mathrm{mL}$ of the TCLP extraction fluid

$\mathrm{V}_{1}=$ mass in $\mathrm{g}$ of supernatant of nominal 100 grams of waste material = $(100 \mathrm{~g}) *(1-\mathrm{W} / 100)$; i.e., $18 \mathrm{~g}$

$\mathrm{V}_{2}=$ mass in $\mathrm{g}$ of TCLP fluid to add to solids fraction of waste material for TCLP extraction $=(100 \mathrm{~g}) *(\mathrm{~W} / 100)$; i.e., $82 \mathrm{~g}$

$\mathrm{F}=20$, the TCLP fluid to solids extraction ratio

$\mathrm{W}=$ centrifuged $w t \%$ solids $(82 \%)$.

The TCLP metals concentrations in the solids from the acid digestion preparations are used for the calculation. The acid digestion results are considered to be conservative since the nitric-hydrochloric acid digestion is significantly more rigorous than the TCLP acetic acid leach. Additional conservatism is ascribed to these calculations in that the results used were not corrected for contributions present in the process blank. Table 4.1 provides the predicted maximum TCLP metals concentration results for the C104 as-received waste material.

The contribution of the solids only to the TCLP metals leach concentration is also provided in Table 4.1 under the heading "20:1 Leach Equivalent." This concentration is calculated according to Equation 3:

$$
\mathrm{C}_{\mathrm{s}}=\mathrm{S} /\left(\mathrm{F} / \mathrm{D}_{2}\right)
$$

Where: $\quad \mathrm{C}_{s}=$ the solid TCLP concentration in $\mu \mathrm{g} / \mathrm{mL}$.

The results indicate that the C-104 waste materials may have TCLP metal concentrations that exceed the regulatory threshold, specifically cadmium, chromium, mercury, and lead. Due to the dilutions required for the analyses to support ALARA (as low as reasonably achievable) radiation exposure concerns and the low regulatory threshold for selenium (i.e., $1 \mu \mathrm{g} / \mathrm{mL}$ ), it cannot be determined if selenium exceeds the threshold. Nickel is included in the TCLP table at the request of BNFL; however, there is no TCLP threshold associated with nickel. 
Table 4.1. TCLP Metals Predicted Maximum Concentrations

\begin{tabular}{|c|c|c|c|c|c|}
\hline \multirow{4}{*}{$\begin{array}{c} \\
\text { TCLP } \\
\text { Analytes }\end{array}$} & \multirow{4}{*}{$\begin{array}{l}\text { TCLP } \\
\text { Limit } \\
\mu \mathrm{g} / \mathrm{mL}\end{array}$} & \multicolumn{4}{|c|}{ C-104 As-Received } \\
\hline & & \multirow{3}{*}{$\begin{array}{c}\text { Supernatänt } \\
\text { Acid Digest } \\
00-1360 \\
\text { Average } \\
\mu \mathrm{g} / \mathrm{mL}\end{array}$} & \multicolumn{2}{|c|}{ Wet:Sólids } & \multirow{3}{*}{$\begin{array}{l}\text { Predicted } \\
\text { Maximum } \\
\text { TCLP } \\
\text { Conc. } \\
\text { Hg/mL }\end{array}$} \\
\hline & & & \multirow{2}{*}{$\begin{array}{c}\text { Acid Digest } \\
\text { 00-1361 } \\
\text { Average } \\
\mu \mathrm{g} / \mathrm{g}\end{array}$} & \multirow{2}{*}{$\begin{array}{c}20: 1 \\
\text { Leach } \\
\text { Equivalent } \\
\text { Average } \\
\mu \mathrm{g} / \mathrm{mL}\end{array}$} & \\
\hline & & & & & \\
\hline$\overline{\mathbf{A g}}$ & 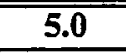 & {$[1.5]$} & [50] & {$[4.2]$} & 2.5 \\
\hline As & 5.0 & $<13$ & $<72$ & $<1.4$ & $<3.7$ \\
\hline $\mathbf{B a}$ & 100.0 & {$[0.5]$} & 84 & 7.1 & 4.2 \\
\hline $\mathbf{C d}$ & 1.0 & 9.4 & 415 & 35 & 20.7 \\
\hline $\mathrm{Cr}$ & 5.0 & 58 & 709 & 60 & 35.7 \\
\hline $\mathrm{Hg}$ & 0.20 & 0.66 & 40.7 & 2.03 & 2.02 \\
\hline $\mathbf{N i}$ & - & 128 & 1,320 & 112 & 66.6 \\
\hline $\mathbf{P b}$ & 5.0 & $<5.0$ & 703 & 60 & $34: 9$ \\
\hline Se & 1.0 & $<13$ & $<72$ & $<6.1$ & $<3.7$ \\
\hline
\end{tabular}

Values in [ ] are above the MDL but below the EQL and have uncertainties $>15 \%$ at 2- $\sigma$.

Shaded and boxed values exceed or potentially exceed regulatory threshold.

(1) The predicted maximum TCLP metals concentration is determined from a nitric/hydrochloric acid leach of the wet centrifuged solids and supernatant. A true TCLP leach could result in significantly lower TCLP metal concentrations. 


\subsection{Quality Control and Data Evaluation}

\subsection{Metals Analysis by ICP - Table 3.1}

Aliquots of the acid-digested and fused samples were submitted to the ICP workstation. The samples were analyzed in two analytical batches following procedure PNL-ALO-211. Where analytes were not detected, the results are reported as less than the MDL. Results shown in brackets "[ ]" are less than the estimated quantitation level (EQL), and have uncertainties exceeding $\pm 15 \%, 2-\sigma$. For the ICP, the EQL is defined as ten times the MDL. Above the EQL, results are expected to have 2- $\sigma$ uncertainties of less than $\pm 15 \%$, and typically less than $\pm 10 \%$.

The analyte concentrations reported for the wet centrifuged solids prepared by acid digestion and $\mathrm{KOH}-\mathrm{KNO}_{3}$ fusion agree reasonably well. Two analytes, Si and $\mathrm{Zr}$, are exceptions; their concentrations are significantly lower in the acid digestion preparation. The fusion preparation method is much better than acid digestion in dissolving $\mathrm{Si}$ and $\mathrm{Zr}$ compounds, thus concentrations derived from the fusion preparation are considered more reliable for $\mathrm{Si}$ and $\mathrm{Zr}$.

Quality control for the ICP analysis consists of duplicates, matrix spikes, blank spikes, post spikes, process blanks, serial dilution, laboratory control standards, and calibration verification check standards. An evaluation of each of the quality control (QC) criteria was performed and a summary is presented below.

Duplicates: Except for a very few cases, the relative percent differences (RPD) for analytes of interest were within the acceptance criterion of $20 \%$. Exceptions are for the fusion preparation of solids for silver $(28 \%)$ and phosphorous (55\%).

Matrix Spikes: A matrix spike was not required to be run with the fusion preparation. Matrix spikes associated with the acid digestion of the liquids and solids recovered within the tolerance limit of $75 \%$ to $125 \%$ except silver (24\% and $27 \%$ ), barium (56\%), and arsenic (50\%). Chloride from the hydrochloric acid used in the acid digestion likely precipitated the silver as $\mathrm{AgCl}$, resulting in low recovery. Low barium recovery may be caused by the presence of sulfate in the sample precipitating barium as $\mathrm{BaSO}_{4}$.

Blank Spikes: Blank spikes were prepared with the acid digestion procedures; a blank spike was not required for the fusion preparation. All spikes recovered within the tolerance limit of $80 \%$ to $120 \%$ except silver (21\%). Chloride from the hydrochloric acid used in the digestion procedure may have precipitated the silver as $\mathrm{AgCl}$ causing low recovery.

Post Spikes: All post-digestion spikes recovered within the tolerance limits of $75 \%$ to $125 \%$.

Process Blanks: Analytes of interest detected in the processing blanks for the acid digestions of the supernatants and solids and the $\mathrm{KOH}-\mathrm{KNO}_{3}$ fusions were below the $\mathrm{EQL}$ or $<5 \%$ of the sample concentration, except for boron in both the acid digestions of the supernatant and solid, and silicon in the acid digestion of solids. The boron concentration was about $6 \%$ of the concentration of the supernatant samples and about $100 \%$ of the concentration in the solids digested samples. The boron and silicon contamination is probably a result of leaching from the borosilicate glass digestion vessel. The boron measured in the acid-digested solid samples appears to be entirely from contamination and the actual boron results should be considered less than the MDL of $26 \mu \mathrm{g} / \mathrm{g}$.

Serial Dilution: The calculated analyte concentrations from the sample analysis and the five-fold dilution of the sample met the acceptance criterion of $\pm 10 \%$, where analyte concentrations exceeded the EQL, 
with one exception. The sodium concentration determined from the $5 \mathrm{X}$ dilution of the wet solids fusion preparation was high by approximately $12 \%$ relative to the undiluted preparation. This indicates the $\mathrm{Na}$ concentration determined from the fusion preparation is potentially low by $12 \%$. The average $\mathrm{Na}$ concentration determined from the acid digestion is higher than the average $\mathrm{Na}$ concentration determined from the fusion preparation by $14 \%$, supporting the low bias indication of the fusion result. Thus the acid digestion result for $\mathrm{Na}$ is more reliable.

Laboratory Control Standard (LCS): A NIST SRM-2710 (Montana Soil) reference standard was processed with the fusion-prepared samples as a LCS. The blank spike served as the LCS for the acid digest samples. For all analytes in the LCS above the EQL, recoveries were within acceptance criteria.

Calibration Verification Check Standards: All standards provided results within acceptance criteria, except for a few analytes. Acceptance criteria for the QC Check Standard are $\pm 10 \%$ of true value. Palladium measured low by $20 \%$ to $27 \%$ in the mixed QC standard run with the fusion-prepared sample series. A single-element palladium standard recovered within $\pm 3 \%$. The acid digested samples were run separately and the mixed QC standard analytes recovered within $\pm 10 \%$ except for magnesium ( $11 \%$ high in one of four measurements) and palladium (20\% low). Again, the single element palladium standard recovered within $\pm 10 \%$. These deviations are not expected to impact the reported analyte results.

\subsection{Uranium Analysis by Kinetic Phosphorimetry- Table 3.1}

Uranium was measured directly in dilutions of the SAL solids fusion and supernatant acid digestion preparations by kinetic phosphorescence analysis (KPA) following procedure PNL-ALO-4014. The diluted samples analyzed were within the concentration range of $1 . E-4$ to $1 . E+0 \mu \mathrm{g} / \mathrm{ml}$. The instrument performance was stable over this range as determined by uranium standards analyzed before and after the sample measurements where standard yields varied between $96 \%$ and $105 \%$. Duplicate sample results showed good agreement with RPD values $<5 \%$. The uranium concentrations measured in the hot cell process blanks were negligible relative to the uranium in the samples. Uranium was not detected in the laboratory blanks. Post-digestion matrix spikes showed excellent recovery at $101 \%$ for the supernate and 99\% for the solids. The uranium KPA results are in good agreement with ICP and ICP-MS results.

\subsection{Radiochemical Analysis -Table 3.2}

\subsubsection{Gamma Emitters by Gamma Energy Analysis (GEA)}

The sample solids fusion and supernatant acid digestion preparations from the SAL were gamma counted following procedure PNL-ALO-450. Most of the gamma emission from the samples was from Cs- 137 . Other detected gamma emitters were Co-60 in the supernatant and solids, and Sb-125, Eu-154, Eu-155, and Am-241 in the solids. All of these gamma emitters were at much lower concentration than the $\mathrm{Cs}-137$. No gamma activity was detectable for $\mathrm{Nb}-94, \mathrm{Ru} / \mathrm{Rh}-106, \mathrm{Sb}-125$ (supernatant), $\mathrm{Sn} / \mathrm{Sb}-126$, or Cs-134. The SAL process blanks had detectable quantities of Cs-137, but at insignificant levels (three orders of magnitude lower) when compared to the Cs-137 levels in the samples. No other gamma emitters were detected in the blanks. All RPD results of detected analytes were $\leq 10 \%$. The Am- 241 results were in excellent agreement with the alpha energy analyses (AEA) discussed below for the solid samples. However, the AEA results had a much lower detection limit and were able to detect Am-241 in the supernatant samples below the GEA detection limit. Since gamma energy analyses are direct sample measurements not involving chemical separations, sample and reagent spikes were not required. 


\subsubsection{Total Alpha and Total Beta}

For total alpha and total beta activity measurements, the SAL solids fusion and supernatant acid digestion sample preparations were further diluted and small aliquots evaporated on planchets for counting following procedures RPG-CMC-4001 and -408 . The total alpha results were in good agreement with the sum of the individual alpha emitters. The supernatant total alpha and alpha sum averaged $4.31 \mu \mathrm{Ci} / \mathrm{mL}$ and $4.07 \mu \mathrm{Ci} / \mathrm{mL}$, respectively, representing a $6 \%$ difference. The wet centrifuged solids total alpha and alpha sum averaged $5.94 \mu \mathrm{Ci} / g$ and $6.58 \mu \mathrm{Ci} / \mathrm{g}$, respectively, reflecting an $11 \%$ difference. (The sum of the alpha emitters is a better indicator of the total alpha activity as direct plating results in potential mass attenuation effects of the total alpha emissions.) The duplicate samples showed good agreement with $\leqq 13 \%$ RPD. Alpha activity was not detected in the SAL process blanks or laboratory blanks. Blank spikes for the solids and liquids showed acceptable recoveries; however, the solids sample alpha spike recovery was low at $73 \%$, probably due to mass attenuation effects. This effect was not an issue with the sum of the individual alpha emitters, as discussed previously.

The total beta results were in reasonable agreement with the sum of the beta emitters, mainly Cs-137 and twice (to allow for Y-90) the Sr-90 activities. The total beta activity for the supernatant averaged 30.4 $\mu \mathrm{Ci} / \mathrm{mL}$ and the sum of the beta emitters averaged $38.8 \mu \mathrm{Ci} / \mathrm{mL}$, representing a $28 \%$ difference. The total beta activity for the wet centrifuged solids averaged $700 \mu \mathrm{Ci} / \mathrm{g}$ and the sum of the beta emitters averaged $652 \mu \mathrm{Ci} / \mathrm{g}$, representing a $7.5 \%$ difference. The duplicate beta activity results agreed within $6 \% \mathrm{RPD}$. The SAL process blanks had beta activity concentrations three to four orders of magnitude less than the samples. The total beta matrix and blank spikes showed excellent recoveries ranging from $98 \%$ to $100 \%$.

\subsubsection{Plutonium, Americium, and Curium}

Plutonium, americium, and curium were separated from diluted SAL solids fusion and supernatant acid digestion preparations using Eichrom TRU resin according to procedure PNL-ALO-417. The separated fractions were mounted for alpha spectroscopy by co-precipitation with a neodymium fluoride $\left(\mathrm{NdF}_{3}\right)$ carrier (procedure PNL-ALO-496) and counted by alpha energy analysis according to procedure PNL-AIO-422. Absolute activity of the alpha emitters was calculated relative to NIST-traceable Pu-242 and Am-243 tracers added to the sample aliquots at the start of the chemistry in the laboratory.

The SAL process blanks indicated detectable alpha emitters for the solids, but the activities were about three orders of magnitude lower than the samples. Where the counting uncertainties were less than $10 \%$ for the sample and duplicate, the plutonium and americium RPD results were $<5 \%$ and well-within the acceptance criterion of $<20 \%$. The blank spike and sample spike showed good yield-corrected recoveries of $82 \%-103 \%$.

The plutonium sample mounts were placed into scintillation cocktail and counted according to PNL-ALO-474. The Pu-241 activity was determined by integrating the $2-20 \mathrm{keV}$ region. Radiochemical yields, assessed through alpha spectrometry, were applied to the sample activity calculations. Because the laboratory was not notified of the need for $\mathrm{Pu}-241$ determination until after the $\mathrm{Pu}-239+240$ analyses were completed, $\mathrm{Pu}-241$ blank spikes and matrix spikes were not prepared. The RPD for the Pu-241 supernatant was $1 \%$; the RPD for the Pu-241 in the solids was $23 \%$, greater than the $<20 \%$ criterion. The mean difference of the solids duplicates was 0.95 indicating the results were not significantly different given the error of the method. ${ }^{1}$

\footnotetext{
${ }^{1}$ The mean difference value indicates whether the results are statistically different at the $95 \%$ confidence level. Where the mean difference is greater than or equal to 1.96 , there is $95 \%$ confidence the two results are not equal.
} 


\subsubsection{Strontium-90}

Small aliquots of the SAL solids fusion and supernatant acid digested samples were taken for Sr-90 analysis. The Sr-90 analyses were conducted according to procedure PNL-ALO-476, which utilizes $\mathrm{Sr}-\mathrm{Spec}$ resin that contains a crown-ether for the selective extraction of strontium from the radioactive and inactive matrix. After thorough washing, the strontium was back-extracted from the resin with water. The water was dried onto 2-inch planchets and counted with a gas-flow proportional counter according to procedure RPG-CMC-408. Radiochemical yields were determined with a Sr-85 tracer (added prior to radiochemical separation) counted by GEA according to procedure PNL-ALO-450. The beta count rate was corrected for the interference from the Sr-85 tracer and Y-90 in growth. The samples were analyzed in two batches; the supernatants were analyzed in one batch and the solids material analyzed in another batch. The wet centrifuged solids sample and duplicate showed good agreement with an RPD of 5\%, well within acceptance criteria of $\angle 20 \%$. The RPD was not reported for the supernatant sample and duplicate because the analytical error for each result exceeded $15 \%$. No contamination was detected in either of the SAL process blanks or the laboratory blank. Sample matrix spikes and blank spikes were prepared in the radioanalytical laboratory and were processed with the sample batches. The blank spike and matrix spike yield-corrected recoveries were excellent at $92-97 \%$. Radiochemical yields were $>95 \%$.

\subsubsection{Tritium}

Tritium was isolated directly from the supernatant sample material and from SAL water leachates of the solids. Tritium was distilled per procedure PNL-ALO-418, followed by liquid scintillation counting of the distillate per procedure PNL-ALO-474. For the liquid samples, the sample duplicates were in good agreement, no tritium was detected in the laboratory blank, and the blank spike showed good recovery at $95 \%$. However, for the solid samples, the sample duplicates showed very poor agreement with an RPD of $136 \%$. The SAL process blank for the water leach of the solids showed significant tritium activity, higher than one sample and at about $20 \%$ of the activity in the other sample. The SAL hot cells are known to have high levels of tritium contamination. Hence, the solids samples appear to be badly contaminated and the solids data are thus only useful as an upper limit to the tritium concentration in the samples. No tritium was detected in the solids blank prepared in the laboratory and a blank spike prepared in the laboratory showed good recovery at $103 \%$. NIST-traceable standards were used to determine the detector efficiency. Due to an oversight, matrix spikes were not prepared for tritium distillation and analysis with either the liquid or solids samples.

\subsubsection{Selenium-79}

The Se-79 was isolated using procedure PNL-ALO-440 in samples of the direct supernatant and in aliquots of the fused solids. In this method the selenium is separated from the sample by precipitation, followed by ion exchange, and then distillation. The product selenium is measured by liquid scintillation counting following procedure PNL-ALO-474. Since a Se-79 calibration standard is not commercially available, blank spikes or matrix spikes could not be prepared. Carbon-14 (which has a nearly identical beta energy) was used to determine the detector counting efficiency. Selenium-79 was not detected in the hot cell process blank for the fusion or in laboratory blanks prepared with each batch of samples. The Se-79 activities measured in the supernatant and solid resulted in $1 \%$ and $4 \%$ RPD respectively. The centrifuged wet solid duplicate sample was also run in replicate by the radioanalytical laboratory and resulted in $49 \%$ higher Se-79 concentration ( $40 \% \mathrm{RPD}$ ). This discrepancy is attributable to the relatively low radiochemical yield of the replicate sample and may also be linked to the general variability of the method near the MDL. 


\subsubsection{Carbon-14}

Carbon-14 was isolated from direct supernatant sample aliquots and wet solids using hot acidic persulfate oxidation and extraction in a Coulometrics Carbon Analyzer Acidification unit followed by $\mathrm{CO}_{2}$ collection in a trap according to procedure PNL-ALO-482. The C-14 was then measured by liquid scintillation counting according to procedure PNL-ALO-474. Both the supernatant and solid sample duplicates showed good agreement with $0 \%$ and $13 \%$ RPDs, respectively. The blank spike showed good recovery of $\mathrm{C}-14$ at $96 \%$, and matrix spikes showed good recoveries at $88 \%$ and $97 \%$, for the solids and supernatants, respectively. Carbon-14 was not detected in the blank samples and there was no evidence of C-14 carry-over into the samples or standards during the combustion process. NIST-traceable C-14 standards were used to determine the net combustion and collection efficiency for the procedure, as well as the detector counting efficiency.

\subsection{Analysis by ICP/MS- Tables 3.3 and 3.4}

Selected radionuclide and metal analyses were performed by ICP/MS per procedures PNL-ALO-280, 281 , and 282. The radionuclide and metal analytes of interest were analyzed on both the acid digestions and water dilutions of the supernatants and on the $\mathrm{KOH}-\mathrm{KNO}_{3}$ fusion preparation. The supernatant water dilution/analysis was evaluated relative to the acid digestion/analysis with respect to iodine. It is chemically feasible to sustain losses of $\mathrm{I}^{-}$by volatilization (as HI) during the acid digestion preparation. The potential for the loss is eliminated with the straight sample dilution. The $\mathrm{Na}_{2} \mathrm{O}_{2}-\mathrm{NaOH}-\mathrm{HCl}$ fusion preparation was used solely for the analysis of platinum. The radionuclide concentrations are presented in both terms of mass $(\mu \mathrm{g})$ and activity $(\mu \mathrm{Ci})$.

Off-line interference corrections were required for I-129 (for xenon correction). Uranium isotopic analyses were conducted on sample fractions processed through TRU-Resin to remove polyatomic ion .interferences. Uranium isotope ratios were then multiplied by the total uranium concentration (determined by summing the U-238 and U-235 concentrations) to report isotopic concentrations. Similarly Pu was purified using TEVA Resin. Plutonium-242 was used as an internal tracer to correct for yield losses and for instrument drift.

The ICP/MS was calibrated relative to isotope-specific standards in all cases except for Pu-240. In this case, the $\mathrm{Pu}-240$ concentration was determined by comparison of its response to the calibration curve for $\mathrm{Pu}-239$ Thus, the Pu-240 concentration results should be considered semi-quantitative.

The analyte RPDs were calculated from duplicate sample results where the individual error was $<15 \%$, 2- $\sigma$. The acid digest preparations of the duplicate supernatant samples were within the $20 \%$ acceptance criterion, except for U-234 where the RPD was $45 \%$. The precision between the sample and duplicate from the water dilution were generally $>20 \%$ for U isotopes. Notably Tc-99, I-129 and I-127, Cs, and Rb were $<20 \% \mathrm{RPD}$ and are chemically stable in dilute caustic solution. The RPDs for the $\mathrm{KOH}-\mathrm{KNO}_{3}$ fusion were within acceptance criteria. The platinum RPD for the $\mathrm{Na}_{2} \mathrm{O}_{2}-\mathrm{NaOH}-\mathrm{HCl}$ fusion of solids was $40 \%$.

Preparation matrix spikes or blank spikes for ICP/MS were not prepared. However, post matrix spikes were prepared and analyzed at the ICP/MS workstation. The post spike recoveries ranged from $79 \%$ to $125 \%$, within the acceptance criteria of $75 \%$ to $125 \%$.

In general, the results of the continuing calibration verification (CCV) check standard were within acceptance criteria. However, one $\mathrm{CCV}$ result exceeded the acceptance criteria as follows: rubidium in the water dilution run series--84\%, technetium in the fusion run series-- $113 \%$, and platinum in the $\mathrm{Na}_{2} \mathrm{O}_{2}-\mathrm{NaOH}-\mathrm{HCl}$ fusion--89\%. The second CCV from each series did meet the acceptance criteria. The 
potential bias introduced by the failure of some of the check standards is considered insignificant, since most of the failures were only marginally outside the acceptance window.

The reported Tc-99 results assume that the ruthenium present is exclusively fission-product ruthenium, and therefore does not have an isotope at mass 99 . The calculated results assume that everything observed at mass 99 is due to technetium. The observed ruthenium mass spectra are not typical of natural ruthenium and are consistent with spectra observed in previous tank waste analyses. Therefore, the assumption that observed mass 99 is primarily technetium should be valid.

The water dilution blank preparation appears to have a significant praseodymium contamination, containing about the same concentration found in the samples. The acid digestion blank result does not demonstrate this contamination and should be used instead. The rubidium and Pu-239 process blank results from the same sample preparation also show evidence of contamination representing $12 \%$ and $10 \%$, respectively, of the sample concentration. The fusion preparation blank also exhibits contamination relative to the sample concentration for several analytes. The preparation blank contains $\mathrm{Rb}$ at $65 \%$ sample concentration, $\mathrm{Pt}$ at $38 \%, \mathrm{Cs}-133$ at $20 \%$, and I-127 at $6 \%$.

For the water soluble analytes, (I, Tc, $\mathrm{Rb}$ and $\mathrm{Cs}$ ), comparison of the acid digestion and water dilution preparations is generally good. The ${ }^{129}$ I concentration agrees well between the acid digestion $(1.12 \mu \mathrm{g} / \mathrm{mL})$ and the water dilution $(1.15 \mu \mathrm{g} / \mathrm{mL})$ samples. The ${ }^{127} \mathrm{I}$ should agree equally well, however, the water dilution value $(0.72 \mu \mathrm{g} / \mathrm{mL})$ is $34 \%$ lower than that from the acid digestion $(1.08 \mu \mathrm{g} / \mathrm{mL})$. This indicates volatilization of $\mathrm{I}^{-}$under the acid digestion processing conditions was not significant. Uranium and plutonium showed greater variability in the water dilution as evidenced by higher RPDs between duplicates. For these analytes, the acid digestion method is considered to produce more reliable results.

The ICP/MS results for $\mathrm{Pu}-239+240$ wet solids fusion preparation compare very favorably to the results obtained by AEA. The supernatant $\mathrm{Pu}-239+240$ concentrations differ by $53 \%$, much greater than the error associated with the two methods. Both methods utilized $\mathrm{Pu}-242$ tracer to correct for yield biases. However, it appears the ICP/MS method is biased high or the radiochemistry method is biased low, or possibly a combination of both. The ICP/MS results for total uranium (i.e., U-238+235) compare well with the results obtained by kinetic phosphorescence and ICP. In general, the average results between the methods vary by less than $10 \%$, which is considered very good agreement for a method-to-method comparison. Table 5.1 presents the comparison for these results. The ICP/MS cannot distinguish between U-238 and Pu-238. However, since the Pu-238 concentration (in $\mu \mathrm{g} / \mathrm{g}$ or $\mu \mathrm{g} / \mathrm{mL}$ ) is negligible, the ICP/MS response at mass 238 is attributed solely to U-238. 
Table 5.1. Comparison of ICP/MS to Other Methods for Pu-239+240 and Total U

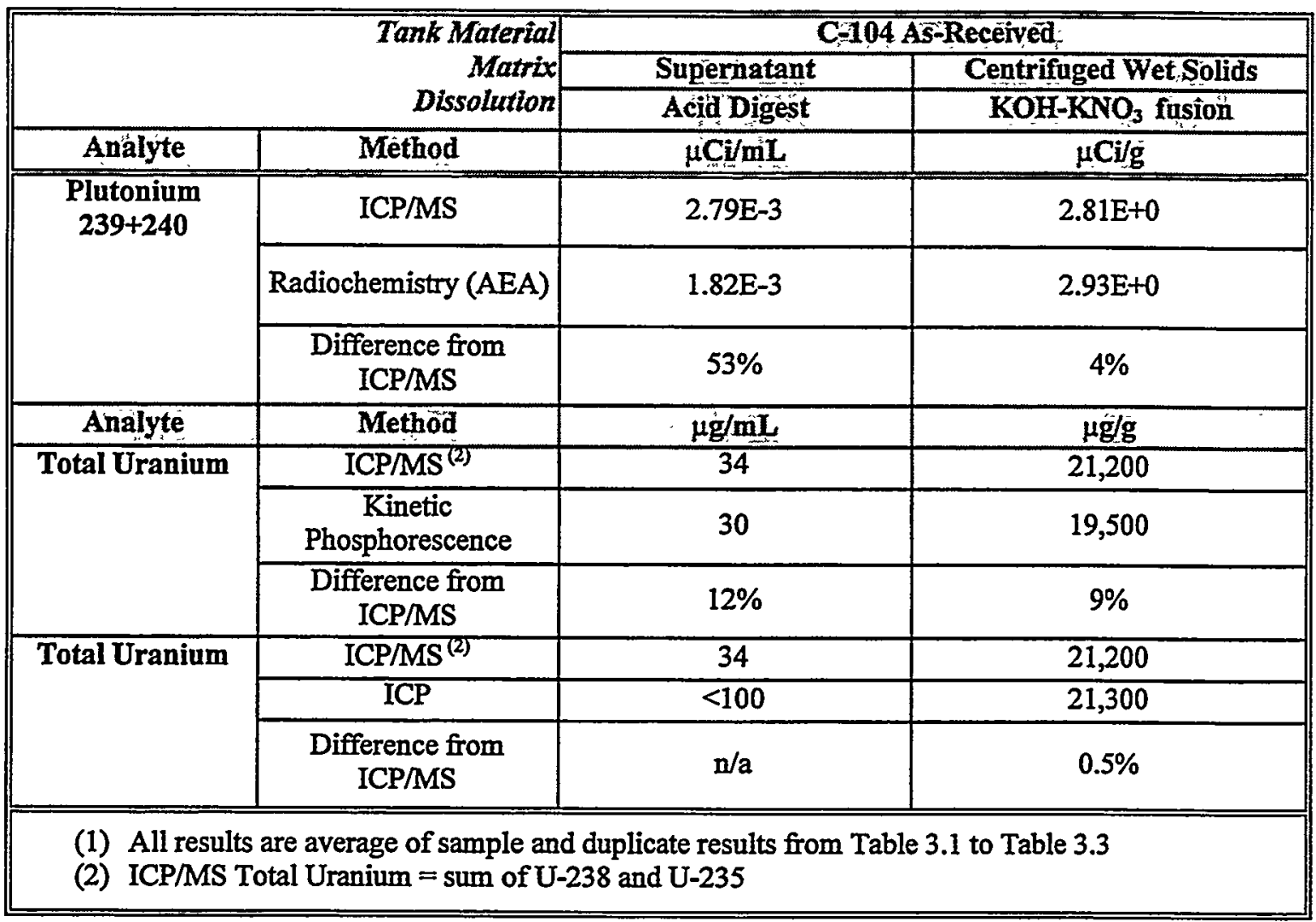

\subsection{TOC/TIC Analysis by Hot Persulfate/Coulometry - Table 3.5}

The analyses of the C-104 as-received supernatant and solids samples were performed by the hot persulfate wet oxidation method, PNL-ALO-381 and the furnace oxidation method, PNL-ALO-380. The hot persulfate method uses acid decomposition for total inorganic carbon (TIC) and acidic potassium persulfate oxidation at $92-95^{\circ} \mathrm{C}$ for TOC (total organic carbon), all on the same weighed sample, with total carbon (TC) being the sum of the TIC and TOC. The furnace oxidation method determines TC by oxidizing all forms of carbon (i.e., inorganic and organic) in oxygen at $1000^{\circ} \mathrm{C}$. Per the analytical method, the TOC, TIC, and TC results are bias-corrected for average percent recovery of system calibration standards and are also corrected for contribution from the system blank.

The QC for the methods involves system calibration blanks, system calibration standards, sample duplicates, and matrix spikes. The QC system calibration standards were all within acceptance criteria, except for the hot persulfate TOC, which demonstrated an average recovery of $88 \%$. Although this recovery is slightly lower than the acceptance criteria, the recovery results were consistent. Because the final results are corrected for the average organic carbon recovery, the slightly low standard recovery is not expected to bias the results. The calibration blanks run at the beginning, middle, and end of the analysis runs were acceptable and the standard deviations for the TIC and TOC blanks were at or below the historical pooled standard deviation used to establish the MDLs.

Under normal conditions, the furnace method and hot persulfate method should provide equivalent TC results. The supernatant results demonstrated good agreement between the furnace and hot persulfate methods, with the average hot persulfate TC being $14,900 \mu \mathrm{g} / \mathrm{ml}$ and the furnace TC being $14,500 \mu \mathrm{g} / \mathrm{ml}$. 
The wet centrifuged solids TC from the furnace method is nearly twice the level measured from the hot persulfate method; i.e., approximately 23,000 versus $13,000 \mu \mathrm{g} / \mathrm{g}$, respectively. The disagreement between the furnace and hot persulfate $\mathrm{TC}$ for the centrifuged solids strongly suggests that the carbon compounds (most likely organic carbon compounds) are not well decomposed by the hot persulfate method.

The accuracy of the carbon measurements can be estimated by the recovery results from the matrix spike. All spike recoveries were within the acceptance criteria of $75 \%$ to $125 \%$. However, the matrix spike for the hot persulfate method demonstrated somewhat low recoveries for the solids; i.e., from $79 \%$ to $87 \%$ for TIC, TOC, and TC. Although these recoveries are within the acceptance criteria, the low recoveries again indicate some difficulties either in subsampling the solids sample or in ability of the hot persulfate method to produce consistent results from the specific sample matrix.

\subsection{Anion Analysis by IC - Table 3.5}

The as-received supernatant samples were diluted 10 -fold to 2000 -fold at the ion chromatography (IC) workstation to ensure that all anions of interest were within the calibration range. The wet solid samples were leached using procedure PNL-ALO-103 in the SAL and further diluted at the IC workstation resulting in a 10 -fold to 2000 -fold dilution. The supernatant and solid leach solutions were analyzed by IC for inorganic anions per procedure PNL-ALO-212.

Although oxalate is an analyte of interest for the as-received material, it is measured by organic IC analysis and reported as an organic anion in the C-104 tank waste organic report (WTP-RPT-008 [draft]). The oxalate results reported in Table 3.4 from the inorganic IC analysis are for information only. The reported fluoride results must be used with caution. For the IC column and parameters used, fluoride cannot be isolated from acetate and formate. It is unlikely the levels of fluoride quantified are present in the C-104 tank waste, and since both acetate and formate could be present, the fluoride results should be used with reservation. Both acetic acid and formic acid were characterized by organic IC analysis and are reported as organic anions in the $\mathrm{C}-104$ organic analysis report.

Matrix spikes were prepared at the IC workstation following the dilution at the IC workstation on the solid leachate sub-sample. The matrix spike demonstrated recoveries between $100 \%$ and $108 \%$, well within the acceptance criteria of $75 \%$ to $125 \%$. The blank spike recoveries were within the $90 \%$ to $110 \%$ acceptance criteria, except for nitrate $(78 \%)$. Other standards analyzed during the analytical run demonstrated good nitrate recovery and the poor nitrate recovery from the blank spike is not considered to affect the reported results. The analytical system blanks, as well as the dilution blanks and leach processing blank, were all within acceptance criteria except for chloride. The leaching blank chloride concentration represents as high as $19 \%$ of the solids chloride concentration, exceeding the $<5 \%$ criterion. However, the blank chloride concentration was virtually at the instrument detection limit and has an associated uncertainty of $100 \%$.

For both the solid leachates and the supernatant samples, the RPD was $16 \%$ or less for all anions, with the exception of phosphate on the solids $(\mathrm{RPD}=115 \%)$. The effectiveness of the water leach to maintain phosphate in solution is considered the primary cause of the large discrepancy in the phosphate results. Although sample heterogeneity cannot be ruled out as a cause for the large discrepancy, the fact the other anions were in close agreement diminish this hypothesis. The phosphorous concentration determined by ICP analysis of the $\mathrm{KOH}-\mathrm{KNO}_{3}$ fusion also resulted in a high $\mathrm{RPD}(55 \%)$. The phosphorous concentration determined from the acid dissolutions of the solids was a small fraction relative to the fusion preparation. Again this points to a solubility problem and a possible heterogeneity problem.

Within the range defined by the IC phosphate results, the ICP phosphorous results are consistent with the IC results. 
As required by the governing QA Plan, mid-range verification standards were analyzed at the beginning of the analysis, after every 10 injections, and at the end of the analysis. For all reported results, all analytes of interest were recovered within the acceptance criteria of $90 \%$ to $110 \%$ for the verification standard. However, due to column degradation caused by a sample from another ASR, one verification standard produced low recoveries (i.e., $80 \%$ to $90 \%$ ). Column performance was recovered following flushing by the eluant. The reported results are considered valid.

\subsection{Mercury Analysis by CVAA - Table 3.5}

The supernatant and solids samples were analyzed by cold vapor atomic absorption spectrophotometry for inorganic mercury. Approximately $0.10 \mathrm{~g}$ mass of wet centrifuged solid samples and approximately 0.5 $\mathrm{ml}(0.57 \mathrm{~g}$ weight) of supernatant liquid samples were transferred to glass digestion vessels by the SAL. Samples were processed and diluted to a final volume of $25.5 \mathrm{ml}$ to $27 \mathrm{ml}$ per procedure PNL-ALO-131. The digestion procedure requires organic matrix destruction using potassium permanganate. The supernatant samples were processed with $0.5 \mathrm{~g}$ additional potassium permanganate and the centrifuged solids were processed with $1 \mathrm{~g}$ additional potassium permanganate. The increased amount of potassium permanganate was used to ensure complete oxidation of potential organic material in the samples. Quality control was assessed with process blanks, blank-spike and matrix-spiked samples that were treated similarly with increased potassium permanganate addition. Following digestion, the samples were analyzed according to PNL-ALO-201. Analytical dilution of 2 to 51-fold was necessary for some samples.

The sample RPDs were within the acceptance criterion of $\leq 20 \%$. The supernatant process blank result was $<5 \%$ of the sample concentration; the wet solids process blank result was less than the detection limit. The blank spikes and supernatant matrix spike recovered $96 \%$ to $108 \%$, well within the acceptance criteria. The Hg spiked in the wet solids matrix was insufficient relative to the sample Hg concentration and the difference could not be measured. The LCS for the solids and liquids recovered $100 \%$ to $113 \%$, well within the acceptance criteria. Three mid-range instrument calibration verification checks recovered $96 \%$ to $105 \%$.

\subsection{Ammonia Analysis by ISE - Table 3.5}

Ammonia was measured directly in the supernatant and in water leachates of the wet centrifuged solids using an ammonia ion specific electrode (ISE). The analysis was performed per procedure PNL-ALO226. The method of standard additions was used to determine the ammonia concentrations by first taking a direct reading and then adding a known standard to each sample. Duplicate results are in good agreement for both the liquid and solid samples with RPD values of $10 \%$ and $9 \%$, respectively. The method detection limit was estimated at $0.2 \mu \mathrm{g} / \mathrm{ml}$ for the liquids. The process blank prepared in the SAL with the water leach sample preparation of the solids shows significant ammonia contamination at about $30 \%$ of the concentration in the sample. It should be noted that the direct sample measurements for the wet solids (before addition of the standards) were below the lowest ammonia standard at $1 . \mathrm{E}-6 \mu \mathrm{g} / \mathrm{ml}$. Hence, the measurements for the wet solids are very close to the estimated detection limit of about 0.8 $\mu \mathrm{g} / \mathrm{g}$, based on half the concentration of our lowest standard.

\subsection{Total Cyanide Analysis by Distillation/Colorimetry - Table 3.5}

Cyanide (CN) was measured in the $\mathrm{C}-104$ supernatant and centrifuged wet solids after distillation by a colorimetric method using an autoanalyzer. Because of the high sample dose rate, the SAL aliquoted small sample aliquots directly into distillation tubes. These were then transferred to the CN workstation. Sulfamic acid was added to the samples prior to distillation to ensure minimal interference from the high nitrate concentration present in the samples. The samples were distilled according to procedure PNL-ALO-287. Cyanide was measured in the distillates according to procedure PNL-ALO-289 using the 
Lachat QuickChem AE Autoanalyzer. Data quality is assessed through the use of sample duplicates, process blanks, blank spikes, matrix spikes, and calibration verification standards.

The RPD measured in both matrices (i.e., $14 \%$ for supernatant and $13 \%$ for solids) was within the acceptance criterion of $<20 \%$. However, these RPDs are higher than typically obtained with this method. The relatively small sample sizes (0.3-g centrifuged wet solids and $0.05-\mathrm{mL}$ supernatant) used to minimize personnel exposure are most likely a major contributor to the poor precision. The process blanks associated with both matrices were less than the instrument detection limit, indicating sample $\mathrm{CN}$ contamination was not measurable. A blank spike, used as the supernatant LCS, recovered $101 \%$. A solid LCS was run with the wet centrifuged solids and recovered well within the certified advisory CN concentration range. The matrix spike recoveries were $94 \%$ (supernatant) and $111 \%$ (wet centrifuged solids), well within the acceptance criteria of $75 \%$ to $125 \%$. The calibration verification standards gave recoveries of $97 \%$ to $101 \%$, well within the acceptance criteria.

\subsection{Flashpoint Determination - Table 3.5}

The C-104 supernatant composite was subjected to a closed-cup flash point test using a Grabner Miniflash apparatus according to procedure PNL-ALO-234. This instrument produces a flash point test equivalent to the SW-846 Pensky-Martin closed-cup method for determining ignitability. However, the Grabner Miniflash apparatus uses only 2-mL sample sizes instead of the 50-mL sample sizes used for the typical Pensky-Martin flash point testers. The 2-mL sample size allows the testing of highly radioactive liquids in the laboratory (versus in a shielded hot cell facility). Dodecane was used as the control standard and water was also tested with the sample set.

The average C-104 flashpoint measured by the Grabner Miniflash tester at $219^{\circ} \mathrm{F}$ is most likely a "false flash" caused by the rapid production of steam at the boiling point of water. The C-104 supernatant composite is essentially an aqueous caustic matrix with essentially no highly volatile or low boiling point organic compounds present (as determined by various organic analyses). When water was subjected to the closed-cup flash point test, a "false flash" at approximately the same flash point $\left(216^{\circ} \mathrm{F}\right)$ was measured. Also, the low flash point pressure (averaging $5.9 \mathrm{kPa}$ in the duplicate supernatant samples) is indicative of the steam "false flash". The "false flash" pressure of water was $6.4 \mathrm{kPa}$. An actual ignition flash point produces a much higher pressure as was evidenced by the control standard dodecane pressures (averaging $26 \mathrm{kPa}$ ).

Dodecane tested prior to, and following, sample analysis must produce a flash point of $184 \pm 4^{\circ} \mathrm{F}$. The initial dodecane test met the acceptance criteria. The dodecane measurement immediately after the C-104 supernatant measurements failed to meet the acceptance criteria. Residual water or water vapor from the previous C-104 aqueous matrix is suspected of creating this problem. An additional dodecane test was performed following sample analysis that did meet the acceptance criteria.

\subsection{Free Hydroxide and $\mathrm{pH}$ Analysis - Table 3.5}

Analysis of free hydroxide was performed on supernatant subsamples according to procedure PNL-ALO-228. The samples were titrated with normalized hydrochloric acid solution. Quality control check standards were prepared from recently standardized sodium hydroxide solution. Duplicate analyses of the QC check standard resulted in measured hydroxide concentrations within $0.7 \%$ of the true hydroxide concentration.

The total hydroxide concentration of 0.81 millimoles $\mathrm{OH}$ per milliliter was calculated from the first equivalence point on the titration curve, $\mathrm{pH} 7.64$ and $\mathrm{pH} 8.16$ for the sample and duplicate with a RPD of $0.4 \%$. To verify that this equivalence point is associated with hydroxide, the supernatant was spiked with sodium hydroxide standard and titrated. The matrix spike first equivalence point was $\mathrm{pH} 7.87$, 
corresponding to the $\mathrm{pH}$ equivalence of the unspiked samples. Recovery of the matrix spike (first equivalence point) was $98 \%$.

The pH measurement was performed directly on one supernatant aliquot per procedure PNL-ALO-225. Because the tank waste was expected to be outside of the calibration buffer range of pH 4 and $\mathrm{pH} \mathrm{10,} \mathrm{a}$ standard $\mathrm{NaOH}$ solution providing $\mathrm{pH} 13.07$ was also determined. The standard resulted in $\mathrm{pH} 12.83$, within $0.24 \mathrm{pH}$ units of true. The $\mathrm{C}-104$ supernatant was determined to be $\mathrm{pH} 12.1$ 


\subsection{Method Detection Limits \& Minimum Reportable Quantities}

The MDLs for specific analytes of interest vary significantly based on the procedures used for preparing the samples for analysis (e.g., acid digestion, fusion), the sample size taken for the analysis, required dilutions for ALARA safety considerations, and the magnitude of interfering analytes. For the work presented in this report, effort was made to optimize the sample preparation parameters (e.g., minimal dilutions). Table 6.1 provides a direct comparison of each analyte MDL to the target minimum reportable quantity (MRQ) provided by BNFL. The MDLs are nominal values based on average sample sizes used for analysis. The MDLs are presented for both liquids and solids. Where solids are prepared by both acid digestion and fusion, both the acid digestion $\mathrm{MDL}$ and fusion $\mathrm{MDL}$ are provided for comparison. The MDLs that are shaded and boxed exceed the BNFL requested MRQs.

As is evident from the Table 6.1, some analytes of interest have not been measured at the target MRQ. Many of the high MDLs are within a factor of five from the target MRQ. These include the supernatant potassium, fluoride, Co-60, and Eu154 and the wet centrifuged solids cobalt molybdenum zinc, chloride, nitrate, TIC, TOC, Eu-155, Pu-238, and U-238. Optimization of sample size and analytical dilutions may help achieve the target MRQs. The sample size increase must always be balanced with the corresponding additional dose to the analyst at the workstation.

Given the sample matrix and processing conditions, the Am-241 by GEA analysis and Pu-241 (in solids) MRQs will probably be unattainable. The Am-241 photopeak is fairly low energy at $59 \mathrm{keV}$ and background continuum from higher energy gamma emitters will adversely affect the Am-241 detection limit. Thus the higher the Cs-137 concentration (as well as other gamma emitters), the higher the Am-241 detection limit will be. However, the Am-241 analysis by AEA did meet the MRQ by two orders of magnitude. It is unlikely than any preparative technique will allow the quantification of $\mathrm{Pu}-241$ in a typical tank waste at the $1.2 \mathrm{pCi} / \mathrm{g}$ level unless very large sample volumes can be prepared for counting.

It is also unlikely that the MRQ of $3 \mu \mathrm{g} / \mathrm{mL}$ chloride can be achieved consistently on tank waste supernatants by using IC as the analysis method. The presence of other anions at high concentrations (e.g., nitrate and nitrite) requires significant dilution of the samples prior to analysis to prevent IC column overloading. This required dilution and the presence of interfering organic anions significantly limit the chloride MDL. 
Table 6.1 Comparison of Measurement MDLs to Target MRQs

\begin{tabular}{|c|c|c|c|c|c|c|c|c|c|c|}
\hline \multirow[b]{2}{*}{ Analyte } & \multicolumn{2}{|c|}{ Tiqụids } & \multicolumn{3}{|c|}{ Solids } & \multirow{2}{*}{$\begin{array}{c}\cdots \\
\text { Radionuclide } \\
\end{array}$} & \multicolumn{2}{|c|}{ Liquidids. } & \multicolumn{2}{|c|}{ Solids's } \\
\hline & $\begin{array}{c}\text { MDL } \\
(1) \\
\mu \mathrm{g} / \mathrm{mL}\end{array}$ & $\begin{array}{c}\text { BNFL } \\
\text { MRQ } \\
\mu \mathrm{g} / \mathbf{m L}\end{array}$ & $\begin{array}{c}\mathrm{MDL} \\
\text { (1) } \\
4 \mathrm{~g} / \mathrm{g}\end{array}$ & $\begin{array}{c}\text { MDL } \\
\text { (Fusion) } \\
\text { ig/g }\end{array}$ & $\begin{array}{l}\text { BNFL } \\
\text { MRQ } \\
\text { Mgig }\end{array}$ & & $\begin{array}{c}M D L \\
(1) \\
\mu \mathrm{C} / \mathrm{mL}\end{array}$ & $\begin{array}{c}\text { BNFL } \\
\mathrm{MRQ} \\
\mathrm{\mu C} / \mathrm{mL}\end{array}$ & $\begin{array}{c}\mathrm{MDL} \\
\text { (Fusion) } \\
\mu \mathrm{CI} / \mathrm{g}\end{array}$ & $\begin{array}{l}\text { BNFL } \\
\text { MRQ } \\
\mu C 1 / g \\
\end{array}$ \\
\hline$\overline{\mathrm{Ag}}$ & $1.2 \mathrm{E}+0$ & $1.75 \mathrm{E}+1$ & $7.1 \mathrm{E}+0$ & $1.1 \mathrm{E}+1$ & $9.00 \mathrm{E}+2$ & $\overline{\mathrm{H}-3}$ & $1 \mathrm{E}-4$ & $\mathrm{n} / \mathrm{a}$ & $4 \mathrm{E}-4$ & $\mathrm{n} / \mathrm{a}$ \\
\hline Al & $3.0 \mathrm{E}+0$ & $7.50 \mathrm{E}+1$ & $1.7 \mathrm{E}+1$ & $2.7 \mathrm{E}+1$ & $3.30 \mathrm{E}+2$ & C-14 & $3.7 \mathrm{E}-7$ & $\mathrm{n} / \mathrm{a}$ & $2.2 \mathrm{E}-6$ & $\mathrm{n} / \mathrm{a}$ \\
\hline As & $1.2 \mathrm{E}+1$ & NMRQ & $7.1 \mathrm{E}+1$ & $1.14 \mathrm{E}+2$ & NMRQ & Co-60 (GEA) & $-3.8 \mathrm{E} 3$ & $2.10 \mathrm{E}-3$ & $2.9 \mathrm{E}-3$ & $1.20 \mathrm{E}-2$ \\
\hline B & $2.5 \mathrm{E}+0$ & NMRQ & $1.4 \mathrm{E}+1$ & $2.3 E+1$ & NMRQ & Se-79 & $2 E-6$ & NMRQ & $7 \mathrm{E}-4$ & NMRQ \\
\hline $\mathrm{Ba}$ & $5.0 \mathrm{E}-1$ & $7.80 \mathrm{E}+1$ & $2.9 \mathrm{E}+0$ & $4.6 \mathrm{E}+0$ & $6.00 \mathrm{E}+2$ & Sr-90 & $2 \mathrm{E}-3$ & $1.50 \mathrm{E}-1$ & $4.0 \mathrm{E}+0$ & $7.01 E+1$ \\
\hline $\mathrm{Be}$ & $5.0 \mathrm{E}-1$ & NMRQ & $2.9 \mathrm{E}+0$ & $4.6 \mathrm{E}+0$ & NMRQ & $\mathrm{Nb}-94$ (GEA) & $2 \mathrm{E}-3$ & NMRQ & $1.3 \mathrm{E}-2$ & NMRQ \\
\hline $\mathbf{B i}$ & $4.9 \mathrm{E}+0$ & NMRQ & $2.9 E+1$ & $4.6 \mathrm{E}+1$ & NMRQ & Ru-106/Rh-106 (GEA) & $3 \mathrm{E}-5$ & NMRQ & $1.5 \mathrm{E}-1$ & NMRQ \\
\hline $\mathrm{Ca}$ & $1.2 \mathrm{E}+1$ & $1.50 \mathrm{E}+2$ & $7.1 E+1$ & $1.1 \mathrm{E}+2$ & $1.80 \mathrm{E}+2$ & Sb-125 (GEA) & $6 \mathrm{E}-2$ & NMRQ & $9.5 \mathrm{E}-2$ & NMRQ \\
\hline $\mathrm{Cd}$ & $7.4 \mathrm{E}-1$ & $7.50 \mathrm{E}+0$ & $4.3 \mathrm{E} \div 0$ & $6.9 \mathrm{E}+0$ & $1.10 \mathrm{E}+1$ & Sn-126 (GEA) & $2 \mathrm{E}-2$ & NMRQ & $3.1 E-2$ & NMRQ \\
\hline Co & $2.5 \mathrm{E}+0$ & $3.00 \mathrm{E}+1$ & $1.4 E+1$ & $2.3 \mathrm{E}+1$ & $3.00 \mathrm{E}+0$ & Cs-134 (GEA) & $2 \mathrm{E}-3$ & NMRQ & $7.1 \mathrm{E}-3$ & NMRQ \\
\hline $\mathrm{Cr}$ & $1.0 \mathrm{E}+0$ & $1.50 \mathrm{E}+1$ & $5.7 \mathrm{E}+0$ & $9.2 \mathrm{E}+0$ & $1.20 \mathrm{E}+2$ & Cs-137 (GEA) & $7.9 \mathrm{E}-3$ & $9.00 \mathrm{E}+0$ & $1.5 \mathrm{E}-2$ & $6.00 \mathrm{E}-2$ \\
\hline $\mathrm{Cu}$ & $1.2 \mathrm{E}+0$ & $1.70 \mathrm{E}+1$ & $7.1 E+0$ & $1.1 \mathrm{E}+1$ & $1.80 \mathrm{E}+1$ & Eu-154 (GEA) & $-3 \mathrm{E} 3$ & $2.00 \mathrm{E}-3$ & $8.9 \mathrm{E}-3$ & $6.00 \mathrm{E}-2$ \\
\hline Fe & $1.2 \mathrm{E}+0$ & $1.50 \mathrm{E}+2$ & $7.1 E+0$ & $1.1 \mathrm{E}+1$ & $1.40 \mathrm{E}+2$ & Eu-155 (GEA) & $4 \mathrm{E}-2$ & $9.00 \mathrm{E}-2$ & $-7.9 \mathrm{E}-2$ & $6.00 \mathrm{E}-2$ \\
\hline $\mathbf{K}$ & $1.0 \mathrm{E}+2$ & $7.50 \mathrm{E}+1$ & $5.7 \mathrm{E}+2$ & $9.2 \mathrm{E}+2$ & $1.50 \mathrm{E}+3$ & $\mathrm{Pu}-238$ & $2 \mathrm{E}-6$ & $9.60 \mathrm{E}-3$ & $.7 .1 \mathrm{E}-5$ & $6.00 \mathrm{E}-5$ \\
\hline $\mathbf{L a}$ & $2.5 \mathrm{E}+0$ & $3.50 \mathrm{E}+1$ & $1.4 \mathrm{E}+1$ & $2.3 E+1$ & $6.00 \mathrm{E}+1$ & $\mathrm{Pu}-239+\mathrm{Pu}-240$ & $2 \mathrm{E}-6$ & NMRQ & $3.66 \mathrm{E}-5$ & NMRQ \\
\hline $\mathbf{L i}$ & $1.5 E+0$ & NMRQ & $8.6 \mathrm{E}+0$ & $1.4 \mathrm{E}+1$ & NMRQ & Pu-241 & $1 E-4$ & $9.60 \mathrm{E}-3$ & $3.4 \mathrm{E}-1$ & $1.20 \mathrm{E}-6$ \\
\hline $\mathbf{M g}$ & $4.9 \mathrm{E}+0$ & $1.50 \mathrm{E}+2$ & $2.9 \mathrm{E}+1$ & $4.6 \mathrm{E}+1$ & $5.40 \mathrm{E}+2$ & Am-241(GEA) & $4 \mathrm{E}_{-2}$ & $7.20 \mathrm{E}-4$ & $27.7 E^{2} 2$ & $1.20 \mathrm{E}-3$ \\
\hline Mn & $2.5 \mathrm{E}+0$ & $1.50 \mathrm{E}+2$ & $1.4 \mathrm{E}+1$ & $2.3 \mathrm{E}+1$ & $3.00 \mathrm{E}+2$ & Am-241 (AEA) & $4 \mathrm{E}-6$ & $7.20 \mathrm{E}-4$ & $1.1 \mathrm{E}-4$ & $1.20 \mathrm{E}-3$ \\
\hline Mo & $2.5 \mathrm{E}+0$ & $9.00 \mathrm{E}+1$ & $1.4 \mathrm{E}+1$ & $2.3 E+1$ & $6.00 \mathrm{E}+0$ & $\mathrm{Cm}-242$ & $5 \mathrm{E}-7$ & NMRQ & $2.2 \mathrm{E}-5$ & NMRQ \\
\hline $\mathrm{Na}$ & $7.4 \mathrm{E}+0$ & $7.50 \mathrm{E}+1$ & $4.3 \mathrm{E}+1$ & $6.9 \mathrm{E}+1$ & $1.50 \mathrm{E}+2$ & $\mathrm{Cm}-243+\mathrm{Cm}-244$ & $2 \mathrm{E}-6$ & $1.50 \mathrm{E}-1$ & $2.2 \mathrm{E}-5$ & $6.00 \mathrm{E}-5$ \\
\hline $\mathrm{Ni}$ & $1.5 \mathrm{E}+0$ & $3.00 \mathrm{E}+1$ & $8.6 \mathrm{E}+0$ & $1.4 \mathrm{E}+1$ & $1.60 \mathrm{E}+2$ & Beta & $2.1 E-4$ & NMRQ & $2.5 \mathrm{E}-1$ & NMRQ \\
\hline $\mathbf{P}$ & $4.9 \mathrm{E}+0$ & NMRQ & $2.9 \mathrm{E}+1$ & $4.6 \mathrm{E}+1$ & NMRQ & Alpha & $1 \mathrm{E}-4$ & $2.30 \mathrm{E}-1$ & $7.1 \mathrm{E}-3$ & $1.00 \mathrm{E}-3$ \\
\hline $\mathbf{P b}$ & $4.9 \mathrm{E}+0$ & $3.00 \mathrm{E}+2$ & $2.9 \mathrm{E}+1$ & $4.6 \mathrm{E}+1$ & $6.00 \mathrm{E}+2$ & Sum Alpha & $1 \mathrm{E}-5$ & NMRQ & $2.6 \mathrm{E}-4$ & NMRQ \\
\hline $\mathbf{P d}$ & $3.7 \mathrm{E}+1$ & NMRQ & $2.14 \mathrm{E}+2$ & $3.4 \mathrm{E}+2$ & NMRQ & Radionüclide & $\mu \mathrm{Ci} / \mathrm{mL}$ & $\mu \mathrm{Ci} / \mathrm{mL}$ & $\mu \mathrm{g} / \mathrm{g}$ & $\ddot{\mu g} / g$ \\
\hline $\mathbf{R h}$ & $1.5 \mathrm{E}+1$ & NMRQ & $8.6 \mathrm{E}+1$ & $1.4 \mathrm{E}+2$ & NMRQ & Tc-99 (ICP/MS) & $3.4 \mathrm{E}-5$ & $1.50 \mathrm{E}-3$ & $2 \mathrm{E}-3$ & $6.00 \mathrm{E}+0$ \\
\hline Sb & $2.5 \mathrm{E}+1$ & NMRQ & $1.4 \mathrm{E}+2$ & $2.3 \mathrm{E}+2$ & NMRQ & I-129 (ICP/MS & $81 E-6$ & $1.10 \mathrm{E}-3$ & $2.4 E-4$ & $3.00 \mathrm{E}+1$ \\
\hline $\mathrm{Se}$ & $1.2 \mathrm{E}+1$ & NMRQ & $7.1 \mathrm{E}+1$ & $1.1 \mathrm{E}+2$ & NMRQ & U-233 (ICP/MS) & $2 \mathrm{E}-5$ & $1.80 \mathrm{E}-3$ & $7 \mathrm{E}-3$ & $6.00 \mathrm{E}+0$ \\
\hline $\mathrm{Si}$ & $2.5 \mathrm{E}+1$ & $1.70 \mathrm{E}+2$ & $1.4 \mathrm{E}+2$ & $2.3 \mathrm{E}+2$ & $3.00 \mathrm{E}+3$ & U-234 (ICP/MS) & $6 \mathrm{E}-6$ & NMRQ & $7 \mathrm{E}-7$ & NMRQ \\
\hline Sn & $7.4 \mathrm{E}+1$ & NMRQ & $4.3 \mathrm{E}+2$ & $6.9 E+2$ & NMRQ & U-235 (ICP/MS) & $4 \mathrm{E}-8$ & $3.30 \mathrm{E}-6$ & $2 \mathrm{E}-5$ & $6.00 \mathrm{E}+0$ \\
\hline $\mathrm{Ti}$ & $1.2 \mathrm{E}+0$ & $1.70 \mathrm{E}+1$ & $7.1 \mathrm{E}+0$ & $1.1 E+1$ & $1.50 \mathrm{E}+2$ & U-236 (ICP/MS) & $8 \mathrm{E}-8$ & NMRQ & $8 \mathrm{E}-5$ & NMRQ \\
\hline $\mathrm{TI}$ & $2.5 \mathrm{E}+1$ & NMRQ & $1.4 \mathrm{E}+2$ & $2.3+2$ & NMRQ & U-238 (ICP/MS) & $2 \mathrm{E}-7$ & $5.00 \mathrm{E}-7$ & $3.5 \mathrm{E}-7$ & $6.00 \mathrm{E}+0$ \\
\hline $\mathbf{U}$ & $9.9 \mathrm{E}+1$ & $6.00 \mathrm{E}+2$ & $5.7 \mathrm{E}+2$ & $9.1 E+2$ & $6.00 \mathrm{E}+2$ & $\mathrm{~Np}-237(\mathrm{ICP} / \mathrm{MS}$ & $2.4 \mathrm{E}-6$ & $2.70 \mathrm{E}-2$ & $3 E-4$ & $1.80 \mathrm{E}+0$ \\
\hline Total U $U^{(2)}$ & $5 \mathrm{E}-3$ & $6.00 \mathrm{E}+2$ & n/a & $4 \mathrm{E}-1$ & $6.00 \mathrm{E}+2$ & Pu-239 (ICP/MS) & $2.5 \mathrm{E}-5$ & $9.60 \mathrm{E}-3$ & $2.6 \mathrm{E}-2$ & $6.00 \mathrm{E}+0$ \\
\hline $\mathbf{V}$ & $2.5 \mathrm{E}+0$ & NMRQ & $1.4 \mathrm{E}+1$ & $2.3 \mathrm{E}+1$ & NMRQ & $\mathrm{Pu}-240$ (ICP/MS) & $1.3 \mathrm{E}-4$ & NMRQ & $3.8 \mathrm{E}-2$ & NMRQ \\
\hline $\mathbf{w}$ & $9.9 \mathrm{E}+1$ & NMRQ & $5.7 \mathrm{E}+2$ & $9.1 \mathrm{E}+2$ & NMRQ & Analyte & $\mu \mathrm{g} / \mathbf{m L}$ & $\mu \mathrm{g} / \mathrm{mL}$ & $\mu g / g$ & $\mu \mathrm{j} / \mathrm{g}$ \\
\hline $\mathbf{Y}$ & $2.5 \mathrm{E}+0$ & NMRQ & $1.4 \mathrm{E}+1$ & $2.3 \mathrm{E}+1$ & NMRQ & $\mathrm{Cs}(\mathrm{ICP} / \mathrm{MS})$ & $4 \mathrm{E}-3$ & NMRQ & $3 \mathrm{E}-1$ & NMRQ \\
\hline $\mathbf{Z n}$ & $2.5 \mathrm{E}+0$ & $1.65 \mathrm{E}+1$ & $1.4 \mathrm{E}+1$ & $2.3 \mathrm{E}+1$ & $6.00 \mathrm{E}+0$ & I(ICP/MS) & $2 \mathrm{E}-3$ & NMRQ & $6 \mathrm{E}-1$ & NMRQ \\
\hline $\mathbf{Z r}$ & $2.5 \mathrm{E}+0$ & NMRQ & $1.4 \mathrm{E}+1$ & $2.3 \mathrm{E}+1$ & $6.00 \mathrm{E}+2$ & $\operatorname{Pr}(\mathrm{ICP} / \mathrm{MS})$ & $1 \mathrm{E}-3$ & NMRQ & $4 \mathrm{E}-1$ & NMRQ \\
\hline & & & & & & Pt(ICP/MS) & $\mathrm{n} / \mathrm{a}$ & NMRQ & & NMRQ \\
\hline$\overline{\mathbf{B r}}$ & $2.5 \mathrm{E}+2$ & NMRQ & $2.5 \mathrm{E}+2$ & $\mathrm{n} / \mathrm{a}$ & NMRQ & $\mathrm{Rb}(\mathrm{ICP} / \mathrm{MS})$ & $6 \mathrm{E}-4$ & NMRQ & $5 E-1$ & NMRQ \\
\hline $\mathrm{Cl}$ & $2.5 \mathrm{E}+2$ & $3.00 \mathrm{E}+0$ & $2.5 E+2$ & $\mathrm{n} / \mathbf{a}$ & $2.30 \mathrm{E}+2$ & Ta(ICP/MS) & 2E-3 & NMRQ & $1.2 \mathrm{E}-1$ & NMRQ \\
\hline $\mathbf{F}$ & $25 E+2$ & $1.50 \mathrm{E}+2$ & $2.5 \mathrm{E}+2$ & $\mathrm{n} / \mathrm{a}$ & $7.50 \mathrm{E}+3$ & OH (free, total) & $1.0 \mathrm{E}+2$ & $1.70 \mathrm{E}+2$ & n/a & $n / a$ \\
\hline $\mathrm{NO}_{2}$ & $5.0 \mathrm{E}+2$ & NMRQ & $5.0 \mathrm{E}+2$ & $\mathrm{n} / \mathrm{a}$ & NMRQ & $\mathbf{H g}$ & 1.0E-2 & $2.00 \mathrm{E}+0$ & $5 \mathrm{E}-2$ & $1.50 \mathrm{E}+0$ \\
\hline $\mathrm{NO}_{3}$ & $5.0 \mathrm{E}+2$ & $3.00 \mathrm{E}+3$ & $5.0 \mathrm{E}+2$ & $\mathrm{n} / \mathrm{a}$ & $4.50 \mathrm{E}+2$ & $\mathrm{CN}$ & $2.5 \mathrm{E}-1$ & NMRQ & $2 \mathrm{E}-1$ & NMRQ \\
\hline $\mathrm{PO}_{4}$ & $5.0 \mathrm{E}+2$ & $2.50 \mathrm{E}+3$ & $5.0 \mathrm{E}+2$ & $n / a$ & $6.00 \mathrm{E}+2$ & $\leftarrow \mathrm{PO}_{4}$ solids $\mathrm{MDL}$ an & RQ as $\mathrm{P}$ & & & \\
\hline $\mathrm{SO}_{4}$ & $5.0 \mathrm{E}+2$ & $2.30 \mathrm{E}+3$ & $5.0 \mathrm{E}+2$ & $\mathrm{n} / \mathrm{a}$ & $1.20 \mathrm{E}+3$ & $\leftarrow \mathrm{SO}_{4}$ solids $\mathrm{MDL}$ an & $R Q$ as $S$ & & & \\
\hline $\mathrm{C}_{2} \mathrm{O}_{4}$ & $5.0 \mathrm{E}+2$ & NMRQ & $5.0 \mathrm{E}+2$ & $\mathrm{n} / \mathrm{a}$ & NMRQ & (1) Acid Digestion, W & Leach, 0 & Direct Anal & lysis, as & licable \\
\hline TIC & $7.0 \mathrm{E}+1$ & $1.50 \mathrm{E}+2$ & $1.2 \mathrm{E}+2$ & $\mathrm{n} / \mathrm{a}$ & $3.00 \mathrm{E}+1$ & (2) Total uranium by ki & etic phosp & rescence & & \\
\hline TOC & $2.0 \mathrm{E}+2$ & $1.50 \mathrm{E}+3$ & $35 \mathrm{E}+2$ & n/a & $6.00 \mathrm{E}+1$ & (3) TC by the furnace $o$ & idation me & & & \\
\hline $\mathrm{TC}^{(\mathfrak{)})}$ & $1.8 \mathrm{E}+2$ & NMRQ & $5.0 \mathrm{E}+2$ & $\mathrm{n} / \mathrm{a}$ & NMRQ & NMRQ: no MRQ provid & d; n/a: not & 1alzyezed & & \\
\hline $\mathrm{NH}_{3}$ & 0.2 & NMRQ & 0.8 & $n / a$ & NMRQ & Note: Shaded an & boxed $\mathrm{MD}$ & s exceed $t$ & he target I & IRQ \\
\hline
\end{tabular}


$\frac{7}{0}$
$\frac{m}{2}$
$\frac{0}{x}$
$>$ 


\section{Appendix A: Test Plan and ASR}

A.1 


\section{\%ำ Baltelle

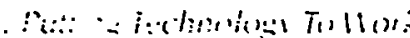

902 Batrelle Boulevard

P.O. Box 999

Richland, Washington 99352

Telephone (509) 376-1982

Email eugene.morrey@pnl.gov

$F_{2 x}(509)$ 376-7127

January 28, 2000

Mr. Michael Johnson

29953-114

Contracting Officer's Technical Representative

3000 George Washington Way

Mailstop: BN-FL

Richland, WA 99352

Dear Mr. Johnson:

TRANSMITTAL OF FINAL TEST PLAN "INORGANIC, ORGANIC AND RADIOCHEMICAL CHARACTERIZATION OF C-104 HLW SAMPLE” BNFL-29953-030, REV 0.

Reference: 1) "Quality Assurance Project Plan for Testing Programs: Savannah River . Technology Center ( SRTC) and Pacific Northwest National Laboratory (PNNL), QP-W375-EN00002, Rev. 0, dated June 7, 1999.

Enclosed is a fully signed test plan of BNFL-29953-030, "Inorganic, Organic and Radiochemical Characterization of C-104 HLW Sample." The test plan details the regulatory characterization analyses to be conducted on material from Tank C-104. The test plan does not include all analyses identified in Appendix B of the recently distributed "Quality Assurance Project Plan for Testing Programs, dated June 7, 1999 (Reference 1). The electronic copy of the test plan was transmitted to you on $1 / 28 / 00$ by Chrissy Charron.

Battelle's deviation from Appendix B of the referenced QA Plan is the same as those agreed to for the analysis of materials from Tanks AN-107 and AW-101. The exceptions include deletion of specific analytical tests, deletion of a few organic analytes of interest, and deletion of TCLP leach test and analysis. The Exception Section of the test plan provides further details. No costs were included in the recent Baseline Change Request (BCR) to cover the deleted analyses or analytes.

Technical matters shall be referred to Mike Urie, 376-9454. 
Mr. Michael Johnson

January 28, 2000

Page 2

Sincerely,

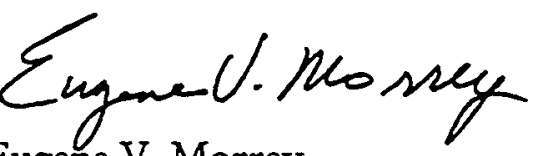

Eugene V. Morrey

Project Manager

EVM: $c^{2}$

Enclosure

Cc: Mike Urie, Battelle (w/attachment) BNFL Project File/LB 


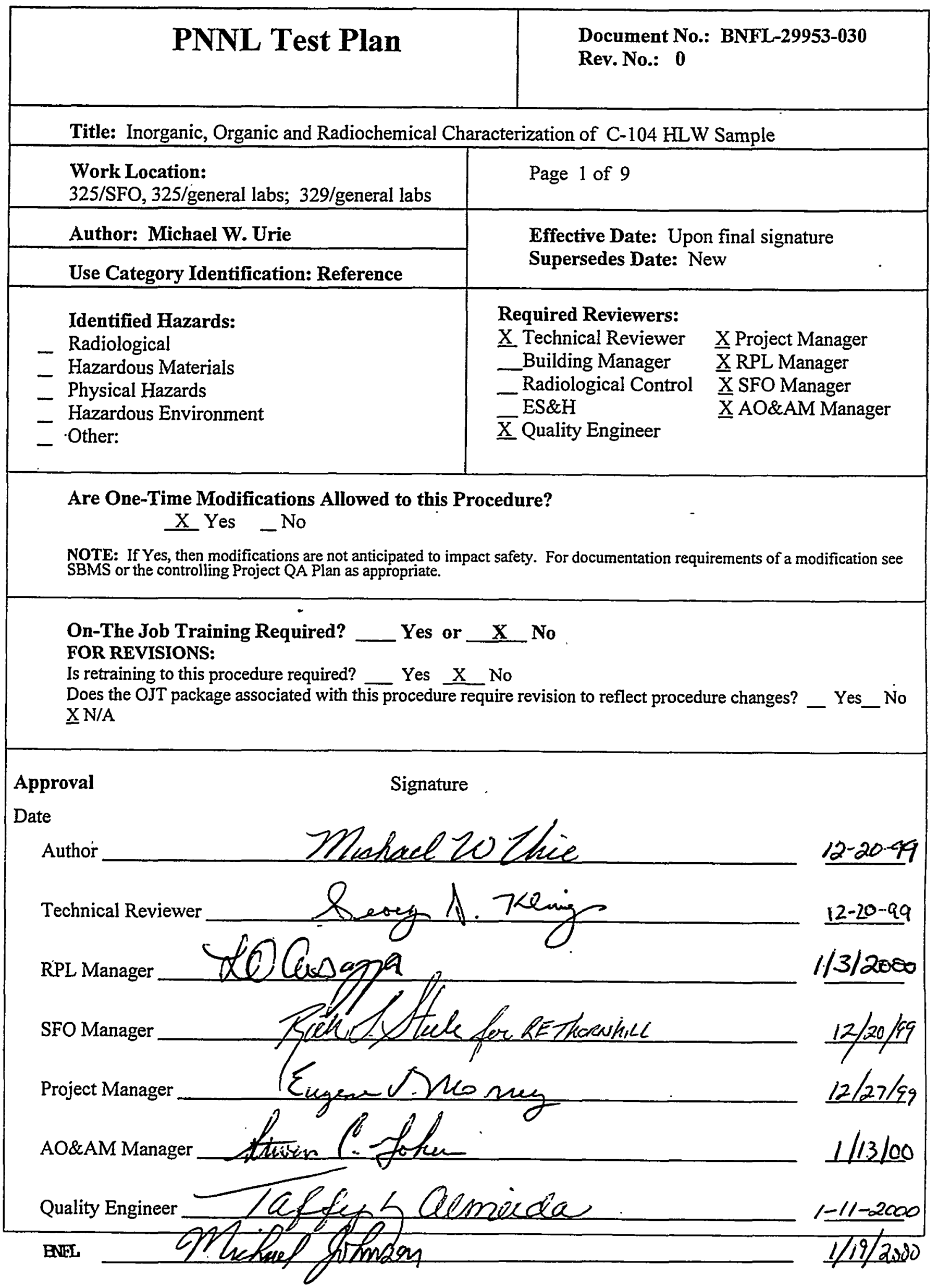




\section{Applicability}

This Test Plan describes work to be performed under Task 5.0, Double Shell Tank Analytical Support Change No. 1, for tank wastes from C-104. A composite generated from Test Plan TP-29953-031, "C-104 Sample Compositing", provide the starting material for the inorganic, organic, and radiochemical characterization of the "as received" tank waste material. Per TP-29953-031, two bottles containing approximately 340 grams of slurry and one jar containing approximately 175 grams of decanted supernatant are allocated to support the "as received" characterization analysis. The representative slurry and supernatant sub-samples are extracted from the C-104 HLW composite sample in the High Level Radiation Facility and transferred to the Shielded Analytical Laboratory for analytical sub-sampling, digestion, extraction, and distribution for analysis.

The characterization of the "as received" tank waste materials is conducted to provide key characterization information for processing, as well as to provide limited information for the permitting activities. This Test Plan covers the sub-sampling and processing of analytical samples, and the inorganic, organic and radiochemical analysis of these samples to provide both precise and accurate compositional results that meet, when possible, regulatory requirements.

This Test Plan does not cover physical properties testing on the C-104 material. Physical properties testing is to be conducted under an alternate test plan. Also, this Test Plan does not include analyses to support the dilution of the C-104 material for the CUF activities, nor does it include the inorganic and radiochemical analysis for the resulting diluted material.

\section{Prerequisites}

The majority of sub-sampling, analytical processing, and inorganic, organic and radiochemical analysis are being conducted per established and approved Battelle procedures or analytical test plans written specifically to support the work detailed in this Test Plan. The Battelle technical procedures and test plans supporting the characterization activity adhere to SW-846 protocols to the extent possible considering the limited sample volume, radiological condition, and extended target analyte list.

\section{Hazards Assessment and Mitigation}

All hazards associated with work conducted to this Test Plan have either been evaluated as part of each laboratory's Hazard Awareness Summary or as hazards unique to a specific analytical preparation or specific analytical procedures or test plans. The Hazard Awareness Summaries are posted for all laboratories in the Radiological Processing Laboratory. Hazards unique to analysis procedures are identified in the applicable procedures or test plans, and where applicable, specific Chemical Processing Permits are obtained.

\section{Quality Control}

Quality control is governed by Quality Assurance Planning Subject Area, including Exhibit "Conducting Analytical Work in Support of Regulatory Progams". The Subject Area Exhibit specifies calibration and verification requirements for analytical systems, as well as batch processing quality control samples to monitor preparation and extraction processing (i.e., blanks, duplicates, matrix spikes, matrix spike duplicates, and laboratory control standards). This Test Plan identifies those analyses for which duplicates and matrix spikes are to be performed, and the approximate quantity of sample to be used for each analysis.

Technical procedures used to support the characterization of the HLW material are either from Chemical Measurement Center Core Capabilities Manual or are project-specific procedures/test plans written specifically to support activities identified in this Test Plan. Necessary method modifications and deviations from technical procedures, test plans, or SW-846 protocols shall be documented in the final report. 
Integrity of the sub-samples and processed samples distributed throughout the laboratory will be maintained by chain-of-custody documentation. Changes to this Test Plan (initialed markups are allowed) shall be approved by the Task Manager.

\section{Exceptions}

Based on the history of the C-104 sample, exceptions are being taken to the preservation, temperature control, and hold time requirements specified by SW-846 protocols. The samples are not preserved and no refrigeration of the samples is practical at this time. Hold times, based on sampling dates, have been exceeded prior to sample receipt and starting the analytical characterization.

In some cases, sample sizes based on SW-846 protocols are not attainable due to limited sample quantity. A limited quantity of material is available for the characterization analyses, and to the extent possible, the sample material is allocated based on the PNNL method sensitivity and ability to meet Minimum Reportable .Quantities (MRQ). The sample volumes and weights used for analyses may be less than the recommended values in SW-846. The effect of small sample size on detection limits and reproducibility will be discussed in the final report. Specifically, the quantity of supernatant available for analysis is insufficient to ensure that all the MRQs are met. All the supernatant from the C-104 "as received" material is targeted to support the regulatory analyses, including inorganic, radiochemical, and organic analytes of interest.

Due to the limited sample quantity, deviations from SW-846 preparation methods may be necessary (e.g., modification to organic extraction procedure). Per the QA Planning Subject Area Exhibit, modifications (e.g., single organic extraction protocol) require Task Leader approval prior to performing the analysis. Formal method qualification of minor modifications will not be performed, but the modification will be validated by the use of duplicate, matrix spikes and surrogates. Modifications, as well as minor deviations to procedures or SW-846 protocols that do not effect data quality, will be documented in the final report.

Per discussion with WDOE and BNFL, certain analyses included in the Battelle Proposal No. 29274/30406 (for AN-107, AW-101, and C-104 tank waste materials) are not being performed, specifically, Total Oil and Grease, Sulfide, Iodide, Nitrogen, Corrosion Test, Reactive Cyanide, Reactive Sulfide, and ZHE for VOA. Also, three organic analytes (ammonium perfluorooctanoate, oxirane, and picric acid) are being omitted from the organic analysis analyte list following discussions with BNFL and WDOE. Also, per letter communication from BNFL, no TCLP extractions of the solids are being conducted for either inorganic or organic constituents.

Based on radiological dose considerations, the analytical samples may be diluted to reduce the dose to laboratory staff. This may significantly impact the ability to meet the MRQs for some analytes.

\section{Work Instructions}

A simple flowchart for the sub-sampling activity is provided in Figure 1. The analysis methods are contained in Appendix A of the Battelle Proposal No. 29274/30406 and are not duplicated. in this Test Plan. Analytical work is either initiated by a standard Analytical Service Request that will identify each test to be performed on the various samples and sub-samples or through the implementation of an analysis-specific test plan. 


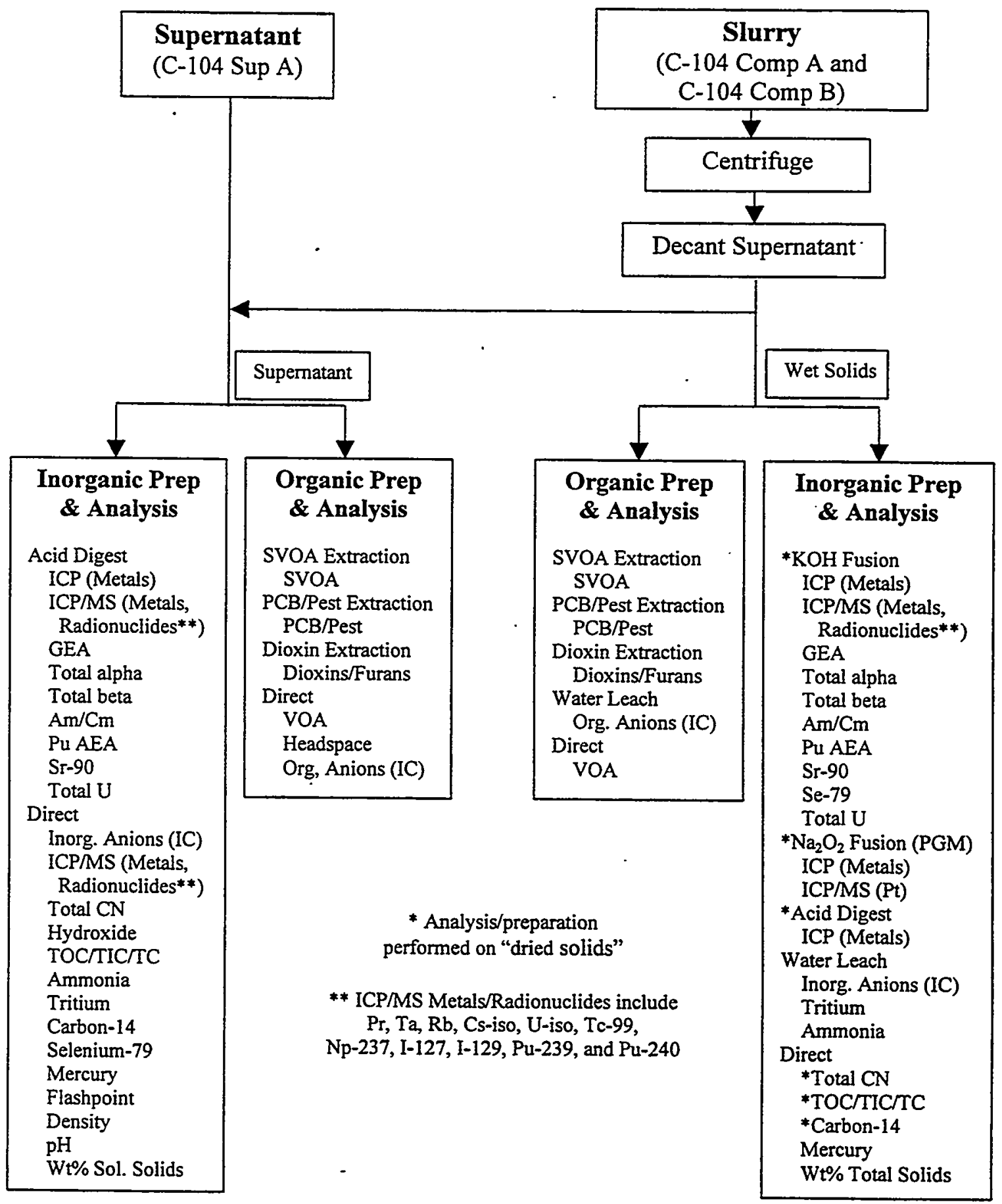

Figure 1. Analytical Sub-Sampling Flowchart

The starting analysis material consists of two containers of representative composite slurry and one container of decanted superantant. The supernatant from the two slurry containers and the decanted supernatant represent essentially all of the supernatant available for characterization analysis. If slurry from the two containers have to be combined prior to sub-sampling, the entire contents of the containers shall be thoroughly homogenized, by mechanical mixing, prior to extracting any sub-samples. All material sub-sampling and most analytical processing (e.g., digestions, fusions, and organic extractions) will be performed in the Shielded Analytical Laboratory due to dose levels. 


\subsection{Sub-Sampling and Phase Separation}

The slurry and supernatant materials for "as received" characterization analysis are contained in three sample containers as described in Test Plan BNFL-29953-031. Table 1 details the container tare values and the sample masses associated with each container.

Table 1. "As Received" Sub-Samples for Characterization

\begin{tabular}{|l|l|c|c|c|}
\hline Sample Material & Bottle ID & $\begin{array}{c}\text { Bottle } \\
\text { Tare (g) }\end{array}$ & $\begin{array}{c}\text { Total } \\
\text { Mass (g) }\end{array}$ & $\begin{array}{c}\text { Supernatant or Slurry } \\
\text { Mass (g) }\end{array}$ \\
\hline \hline Composite Slurry & C-104 Comp A & 133.8 & 302.7 & 168.9 \\
\hline Composite Slurry & C-104 Comp B & 133.5 & 303.8 & 170.3 \\
\hline Supernatant & C-104 Sup A & 248.8 & 424.5 & 175.7 \\
\hline
\end{tabular}

The composite slurry samples are to be centrifuged to provide solids and supernatant phase separation. The supernatant from the slurry samples is decanted from the "wet solids" and combined with the supernatant in C-104 Sup A. The "wet solids" remaining are to be sub-sampled immediately for weight percent solids (in duplicate) and then sub-sampled for all organic analyses, water leaching analyses (i.e., anions, tritium, and ammonia), and mercury analysis as soon as practical. .Following the sub-sampling for organic analysis, water leaching analyses, and mercury analysis, the remaining solids are to be dried to allow representative subsampling for all other analyses to be performed at a later date (i.e., without the necessity of additional weight percent solids measurements).

\subsection{Organic Analysis}

Special care is taken handling both the supernatants and "wet solids" to ensure sample integrity is maintained and representative sub-samples are extracted for analysis. Organic analyses (either direct or following extraction processing) are performed on the supernatant and "wet solids" fractions, and Table 2 details the estimated sub-sampling quantities for each analysis. Appendix A identifies the organic analyte list and associates each compound with an analysis method. Organic compounds other than those listed in Appendix A that are identified during analysis will be noted in the final report.

Test plans will be used to establish the extraction protocols for each extraction process used to generate samples for organic analysis (i.e., SVOA, PCB/Pest, and/or.Dioxin). In order to conserve sample material, the Matrix Spikes and Matrix Spike Duplicates may be prepared using half the sample size used for the Sample and Duplicate.

\subsection{Inorganic and Radiochemistry Sub-Sampling}

Where required by the analysis method, sample preparation by digestion, fusion, or leaching are performed to established and approved Battelle procedures. Table 3 details the estimated sub-sampling quantities of the supernatants, "wet solids", and "dried solids". Inorganic analytes and radionuclides of interest are included in Appendix B. Inorganic analytes and radionuclides other than those listed in Appendix A that are identified during analysis will be noted in the final report.

\subsection{Analytical Service Request and Special Laboratory Instructions}

This Test Plan details the sub-sampling and sample quantity requirements for processing the HLW C-104 "as received" material for inorganic, radiochemistry, and organic analysis. The Analytical Service Request form is to be used to assign unique sample identification numbers to all samples and to identify specific analyses to be performed on each sub-sample. As part of the ASR, special laboratory instructions are to be provided to the laboratory staff to ensure that all sub-sampling and preparation activities are accomplished per this Test Plan. The ASR and the special instruction require review and approval of the Task Leader and become part of the project record once approved and implemented. Changes to the ASR or special instructions also require the approval of the Task Leader. 
Table 2: Organic Analytical Sub-Sampling Quantities Required ${ }^{(1)}$

\begin{tabular}{|c|c|c|c|c|c|}
\hline Phase & Analysis or Procedure & Sample & Duplicate & MS/MSD & $\overline{\mathrm{SW}-846^{(2)}}$ \\
\hline \multirow[t]{5}{*}{ Wet Solids } & VOA & $0.5 \mathrm{~g}$ & $0.5 \mathrm{~g}$ & $0.5 \mathrm{~g}$ & $\overline{5 g}$ \\
\hline & Water Leach (IC Org.) & $1 \mathrm{~g}$ & $1 \mathrm{~g}$ & $1 \mathrm{~g}$ & $n / a$ \\
\hline & Extraction (SVOA) & $5 \mathrm{~g}$ & $5 \mathrm{~g}$ & $5 \mathrm{~g}$ & $30 \mathrm{~g}$ \\
\hline & Extraction (PCB/Pest) & $5 \mathrm{~g}$ & $5 \mathrm{~g}$ & $5 \mathrm{~g}$ & $30 \mathrm{~g}$ \\
\hline & Extraction (Dioxins) & $5 \mathrm{~g}$ & $5 \mathrm{~g}$ & $5 \mathrm{~g}$ & $30 \mathrm{~g}$ \\
\hline \multirow{2}{*}{\multicolumn{2}{|c|}{$\begin{array}{r}\text { Sub Total } \\
\text { Total }\end{array}$}} & $16.5 \mathrm{~g}$ & $16.5 \mathrm{~g}$ & $16.5 \mathrm{~g}$ & \\
\hline & & \multicolumn{3}{|c|}{$49.5 \mathrm{~g}$} & \\
\hline \multirow[t]{6}{*}{ Supernatant } & $\overline{V O A}$ & $2 \mathrm{ml}$ & $2 \mathrm{ml}$ & $2 \mathrm{ml}$ & $5 \mathrm{ml}$ \\
\hline & Headspace & $2 \mathrm{ml}$ & $2 \mathrm{ml}$ & $2 \mathrm{ml}$ & $10 \mathrm{~g}$ \\
\hline & IC (organic anions) & $1 \mathrm{ml}$ & $1 \mathrm{ml}$ & $1 \mathrm{ml}$ & $\mathrm{n} / \mathrm{a}$ \\
\hline & Extraction (SVOA) & $35 \mathrm{ml}$ & $35 \mathrm{ml}$ & $35 \mathrm{ml}$ & $3000 \mathrm{ml}$ \\
\hline & Extraction (PCB/Pest) & $35 \mathrm{ml}$ & $35 \mathrm{ml}$ & $35 \mathrm{ml}$ & $3000 \mathrm{ml}$ \\
\hline & Extraction (Dioxins) & $10 \mathrm{ml}$ & $10 \mathrm{ml}$ & $10 \mathrm{ml}$ & $3000 \mathrm{ml}$ \\
\hline \multirow{2}{*}{\multicolumn{2}{|c|}{$\begin{array}{r}\text { Sub Total } \\
\text { Total } \\
\end{array}$}} & $85 \mathrm{mI}$ & $85 \mathrm{ml}$ & $85 \mathrm{ml}$ & \\
\hline & & \multicolumn{3}{|c|}{$255 \mathrm{ml}$} & \\
\hline
\end{tabular}

(1) Subsampling quantities are estimates; actual quantities used for the analyses will be dictated by the total quantity of material available for analysis.

(2) Typical SW-846 total volume for sample, duplicate, matrix spike, and matrix spiked duplicate extraction

Table 3: Inorganic/Radiochemistry Analytical Sub-Sampling Quantities Required (1)

\begin{tabular}{|c|c|c|c|c|c|}
\hline Phase & Analysis or Procedure & Sample & Duplicate & $\overline{\mathbf{M S}}$ & $5 W-846^{(2)}$ \\
\hline \multirow[t]{7}{*}{ Dried Solids } & Acid Digest (ICP, ICP/MS) & $1 \mathrm{~g}$ & $\overline{1 \mathrm{~g}}$ & $1 \mathrm{~g}$ & $\overrightarrow{3 g}$ \\
\hline & $\begin{array}{c}\text { KOH Fusion (ICP,ICP/MS, } \\
\text { Radiochemistry) }\end{array}$ & $0.3 \mathrm{~g}$ & $0.3 \mathrm{~g}$ & $0.3 \mathrm{~g}$ & $\mathrm{n} / \mathrm{a}$ \\
\hline & $\mathrm{Na}_{2} \mathrm{O}_{2}$ Fusion (ICP, ICP/MS) & $0.3 \mathrm{~g}$ & $0.3 \mathrm{~g}$ & $0.3 \mathrm{~g}$ & $n / a$ \\
\hline & Total CN & $0.5 \mathrm{~g}$ & $0.5 \mathrm{~g}$ & $0.5 \mathrm{~g}$ & $75 \mathrm{~g}$ \\
\hline & TOC/TIC/TC & $0.5 \mathrm{~g}$ & $0.5 \mathrm{~g}$ & $0.5 \mathrm{~g}$ & $\mathrm{n} / \mathrm{a}$ \\
\hline & Carbon-14 & $0.5 \mathrm{~g}$ & $0.5 \mathrm{~g}$ & $0.5 \mathrm{~g}$ & $n / a$ \\
\hline & Selenium-79 & $\mathrm{lg}$ & $1 \mathrm{~g}$ & $1 \mathrm{~g}$ & $n / a$ \\
\hline \multirow[t]{3}{*}{ Wet Solids } & Wt\% Solids & $\ldots 3 \mathrm{~g}$ & $3 g$ & $n / a$ & $\mathrm{n} / \mathrm{a}$ \\
\hline & Water Leach (IC, Ammonia, H-3) & $2 \mathrm{~g}$ & $2 g$ & $2 \mathrm{~g}$ & $\mathrm{n} / \mathrm{a}$ \\
\hline & Mercury & $0.3 \mathrm{~g}$ & $0.3 \mathrm{~g}$ & $0.3 \mathrm{~g}$ & $0.6 \mathrm{~g}$ \\
\hline \multirow{2}{*}{\multicolumn{2}{|c|}{$\begin{array}{r}\text { Sub Totals } \\
\text { Total } \\
\end{array}$}} & $9.4 \mathrm{~g}$ & $9.4 \mathrm{~g}$ & $6.4 \mathrm{~g}$ & 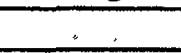 \\
\hline & & \multicolumn{3}{|c|}{$25.2 \mathrm{~g}$} & \\
\hline \multirow[t]{13}{*}{ Supernatant } & $\begin{array}{l}\text { Acid Digest (ICP, ICP/MS, } \\
\text { Radiochemistry) }\end{array}$ & $8 \mathrm{ml}$ & $8 \mathrm{ml}$ & $8 \mathrm{ml}$ & $300 \mathrm{ml}$ \\
\hline & Dilution (ICP/MS) & $1 \mathrm{ml}$ & $1 \mathrm{ml}$ & $1 \mathrm{ml}$ & $\mathrm{n} / \mathrm{a}$ \\
\hline & IC (inorganic anions) & $1 \mathrm{ml}$ & $1 \mathrm{ml}$ & $1 \mathrm{ml}$ & $\mathrm{n} / \mathrm{a}$ \\
\hline & Mercury - & $1 \mathrm{ml}$ & $1 \mathrm{ml}$ & $1 \mathrm{ml}$ & $300 \mathrm{ml}$ \\
\hline & Total CN & $1 \mathrm{ml}$ & $1 \mathrm{ml}$ & $1 \mathrm{ml}$ & $1500 \mathrm{ml}$ \\
\hline & TOC/TIC/TC & $\mathrm{lml}$ & $1 \mathrm{ml}$ & $1 \mathrm{ml}$ & $\mathrm{n} / \mathrm{a}$ \\
\hline & Carbon-14 & $1 \mathrm{ml}$ & $1 \mathrm{ml}$ & $1 \mathrm{ml}$ & $n / a$ \\
\hline & Ammonia & $2 \mathrm{ml}$ & $2 \mathrm{ml}$ & $\mathrm{n} / \mathrm{a}$ & $\mathrm{n} / \mathrm{a}$ \\
\hline & Tritium (H-3) & $2 \mathrm{ml}$ & $2 \mathrm{ml}$ & $2 \mathrm{ml}$ & $\mathrm{n} / \mathrm{a}$ \\
\hline & Hydroxide $(\mathrm{OH}) \& \mathrm{pH}$ & $5 \mathrm{ml}$ & $5 \mathrm{ml}$ & $\mathrm{n} / \mathrm{a}$ & $\mathrm{n} / \mathrm{a}$ \\
\hline & Flashpoint & $2 \mathrm{ml}$ & $2 \mathrm{ml}$ & $\mathrm{n} / \mathrm{a}$ & $150 \mathrm{ml}$ \\
\hline & Total Dissolved Solids & $5 \mathrm{ml}$ & $5 \mathrm{ml}$ & $\mathrm{n} / \mathrm{a}$ & $\mathrm{n} / \mathrm{a}$ \\
\hline & Density & $2 \mathrm{ml}$ & $2 \mathrm{ml}$ & $\mathrm{n} / \mathrm{a}$ & $\mathrm{n} / \mathrm{a}$ \\
\hline \multirow{2}{*}{\multicolumn{2}{|c|}{$\begin{array}{r}\text { Sub Totals } \\
\text { Total }\end{array}$}} & $32 \mathrm{ml}$ & $32 \cdot \mathrm{ml}$ & $16 \mathrm{ml}$ & \\
\hline & & \multicolumn{3}{|c|}{$80 \mathrm{ml}$} & \\
\hline
\end{tabular}

(1) Subsampling quantities are estimates; actual quantities used for the analyses will be dictated by the total quantity of material available for analysis.

(2) Typical SW-846 total volume for sample, duplicate, and matrix spike. 
Appendix A: Organic Analytes of Interest List and MRQs

\begin{tabular}{|c|c|c|c|c|c|}
\hline & \multirow{2}{*}{$\begin{array}{l}\text { MRQ } \\
\mathrm{ug} / \mathrm{Kg}\end{array}$} & \multicolumn{2}{|c|}{$x_{2}+2$} & \multirow{2}{*}{$\begin{array}{l}\text { MRQ } \\
\text { ug/Kg }\end{array}$} \\
\hline CAS & Compound/Element & & CAS & Compound/Element & \\
\hline \multicolumn{6}{|c|}{ PNL-AIO-346(9056) } \\
\hline $144-62-7$ & Oxalic acid & - & $64-19-7$ & Acetic acid & - \\
\hline 64-18-6 & Formic acid & $\overline{-}$ & $79-10-7$ & 2-Propenoic acid & $\overline{-}$ \\
\hline \multicolumn{6}{|c|}{ PNL-ALO-346(3810/5021) } \\
\hline $121-44-8$ & Triethylamine & 500 & $71-23-8$ & n-Propyl alcohol (1-propanol) & $\overline{-}$ \\
\hline $64-17-5$ & Ethyl alcohol & - & $71-36-3$ & n-Butyl alcohol & 900 \\
\hline $67-56-1$ & Methyl alcohol (Methanol) & - & $75-65-0$ & 2-Methyl-2-propanol & - \\
\hline $67-63-0$ & 2-Propyl alcohol (Isopropanol) & - & $78-92-2$ & 1-Methylpropyl alcohol (2-butanol) & - \\
\hline \multicolumn{6}{|c|}{ PNL-ALO-346(8082) } \\
\hline $1336-36-3$ & Polychlorinated biphenyls (PCBs) & 3300 & $58-89-9$ & gamma-BHC (Lindane) & - \\
\hline $309-00-2$ & Aldrin & 22 & $60-57-1$ & Dieldrin & 43 \\
\hline $319-84-6$ & alpha-BHC & 22 & $72-20-8$ & Endrin & 43 \\
\hline $319-85-7$ & beta-BHC & 22 & $72-54-8$ & 4,4'-DDD & $=$ \\
\hline $465-73-6$ & Isodrin & 22 & $76-44-8$ & Heptachlor & 22 \\
\hline $50-29-3$ & 4,4'-DDT & - & $8001-35-2$ & Toxaphene & 900 \\
\hline \multicolumn{6}{|c|}{ PNL-ALO-345(8270C) } \\
\hline $100-00-5$ & p-Nitrochlorobenzene & $\overline{-}$ & $2234-13-1$ & Octachloronaphthalene & - \\
\hline $100-25-4$ & 1,4-Dinitrobenzene & 800 & $50-32-8$ & Benzo(a)pyrene & 1100 \\
\hline $100-51-6$ & Benzyl alcohol & $=$ & $53-70-3$ & Dibenz $[\mathrm{a}, \mathrm{h}] \mathrm{anthracene}$ & 2700 \\
\hline $106-46-7$ & 1,4-Dichlorobenzene & $\overline{-}$ & $541-73-1$ & 1,3-Dichlorobenzene & $=$ \\
\hline $108-95-2$ & Phenol & 2100 & $62-75-9$ & N-Nitroso-N,N-dimethylamine & 800 \\
\hline $110-86-1$ & Pyridine & 5300 & $67-72-1$ & Hexachloroethane & - \\
\hline $1319-77-3$ & Cresol (1) & $=$ & $82-68-8$ & Pentachloronitrobenzene (PCNB) & 1600 \\
\hline $95-48-7$ & 2-Methylphenol (Cresol isomer) & $=$ & $87-68-3$ & Hexachlorobutadiene & 1900 \\
\hline $106-44-5$ & 4-Methylphenol (Cresol isomer) & $\overline{-}$ & $87-86-5$ & Pentachlorophenol & $\overline{-}$ \\
\hline $117-81-7$ & Di-sec-octyl phthalate & $=$ & $88-85-7$ & 2-sec-Butyl-4,6-dinitrophenol (Dinoseb) & - \\
\hline $117-84-0$ & n-dioctyl phthalate & - & $91-20-3$ & Naphthalene & $=$ \\
\hline $118-74-1$ & Hexachlorobenzene & 3300 & $92-52-4$ & 1,1'-Biphenyl & $=$ \\
\hline $120-82-1$ & 1,2,4-Trichlorobenzene & - & $95-50-1$ & 1,2-Dichlorobenzene & 2000 \\
\hline $122-39-4$ & $\mathrm{~N}, \mathrm{~N}$-Diphenylamine (2) & 4300 & $98-86-2$ & Acetophenone & 3200 \\
\hline $126-73-8$ & Tributyl phosphate & 二 & $98-95-3$ & Nitrobenzene & 4700 \\
\hline $128-37-0$ & 2,6-Bis(tert-butyl)-4-methylphenol & $=$ & & & \\
\hline \multicolumn{2}{|c|}{ TEST Plan per 8290} & $\therefore$ & & & \\
\hline 1746-01-6 & 2,3,7,8-Tetrachlorodibenzo-p-dioxin & - & $57117-31-4$ & $2,3,4,7,8$-Pentachlorodibenzofuran & $=$ \\
\hline 19408-74-3 & $1,2,3,7,8,9-$-Hexachlorodibenzo-p-dioxin & $=$ & $57117-41-6$ & 1,2,3,7,8-Pentachlorodibenzofuran & $\overline{-}$ \\
\hline $3268-87-9$ & $1,2,3,4,6,7,8,9-$-Octachlorodibenzo-p-dioxin & $=$ & $57117-44-9$ & 1,2,3,6,7,8-Hexachlorodibenzofuran & - \\
\hline $35822-39-4$ & 1,2,3,4,6,7,8-Heptachlorodibenzo-p-dioxin & - & $57653-85-7$ & $1,2,3,6,7,8$-Hexachlorodibenzo-p-dioxin & $=$ \\
\hline $39001-02-0$ & $1,2,3,4,6,7,8,9-$-Octachlorodibenzofuran & - & $60851-34-5$ & $2,3,4,6,7,8$-Hexachlorodibenzofuran & 二 \\
\hline $39227-28-6$ & $1,2,3,4,7,8-$ Hexachlorodibenzo-p-dioxin & - & $67562-39-4$ & $1,2,3,4,6,7,8$-Heptachlorodibenzofuran & $=$ \\
\hline $40321-76-4$ & 1,2,3,7,8-Pentachlorodibenzo-p-dioxin & - & $70648-26-9$ & $1,2,3,4,7,8$-Hexachlorodibenzofuran & 二 \\
\hline $51207-31-9$ & 2,3,7,8-Tetrachlorodibenzofuran & - & $72918-21-9$ & $1,2,3,7,8,9-$ Hexachlorodibenzofuran & $=$ \\
\hline $55673-89.7$ & $1,2,3,4,7,8,9-$-Heptachlorodibenzofuran & $=$ & & & \\
\hline
\end{tabular}


BNFL-29953-30 Rev. 0

Page 8 of 9

Appendix A: Organic Analytes of Interest List and MRQs

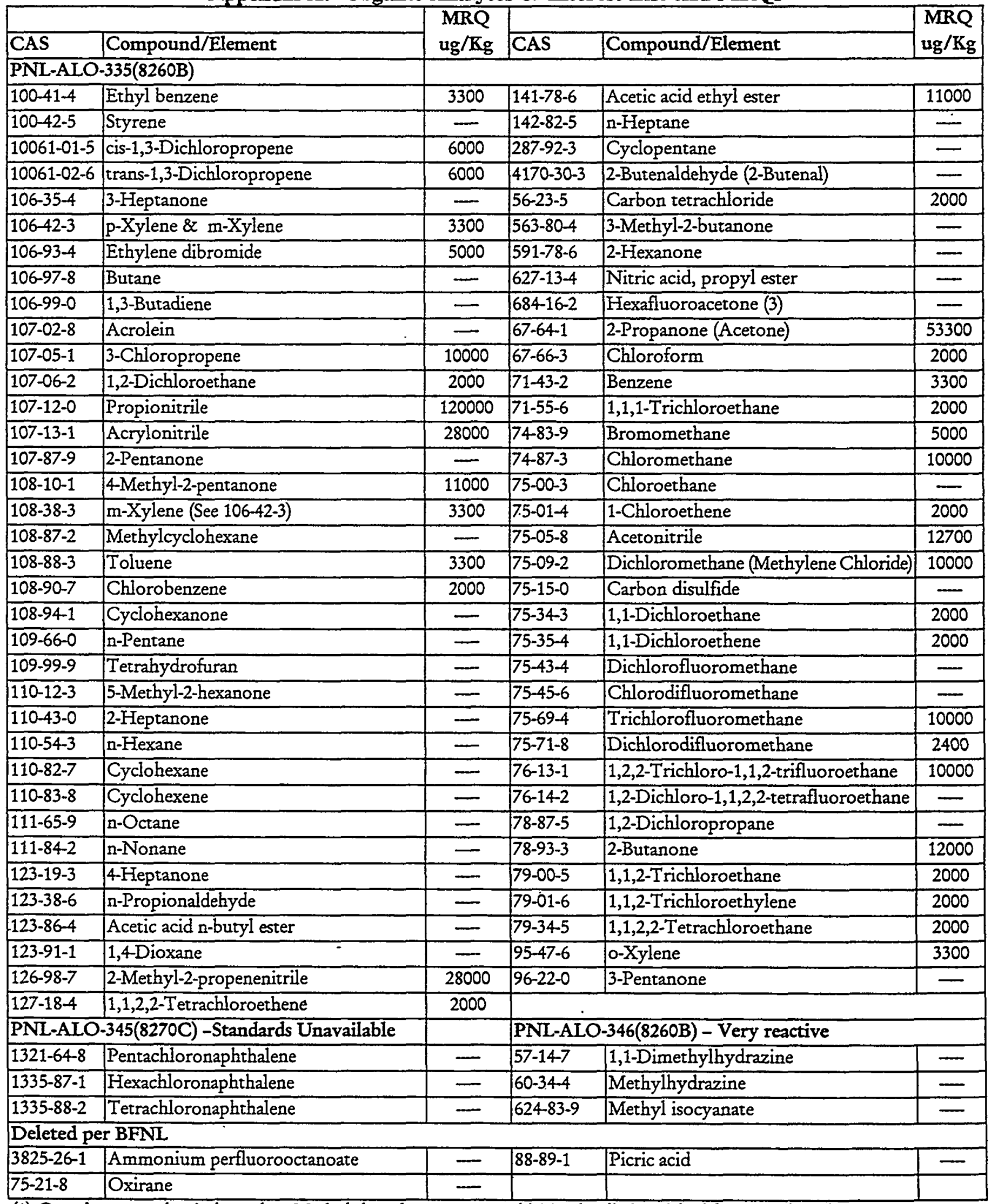

(1) Cresol measured as independent Methylphenols.

(2) Not be distinquished from Diphenylamine

(3) Toxic gas, not previously analyzed

(4) ${ }^{“-}{ }^{\star}=$ No MRQ provided by BNFL 


\section{Appendix B: Inorganic and Radiochemistry Analytes of Interest List}

(Note: No MRQs Provided For Inorganic Analytes or Radionuclides of Interest)

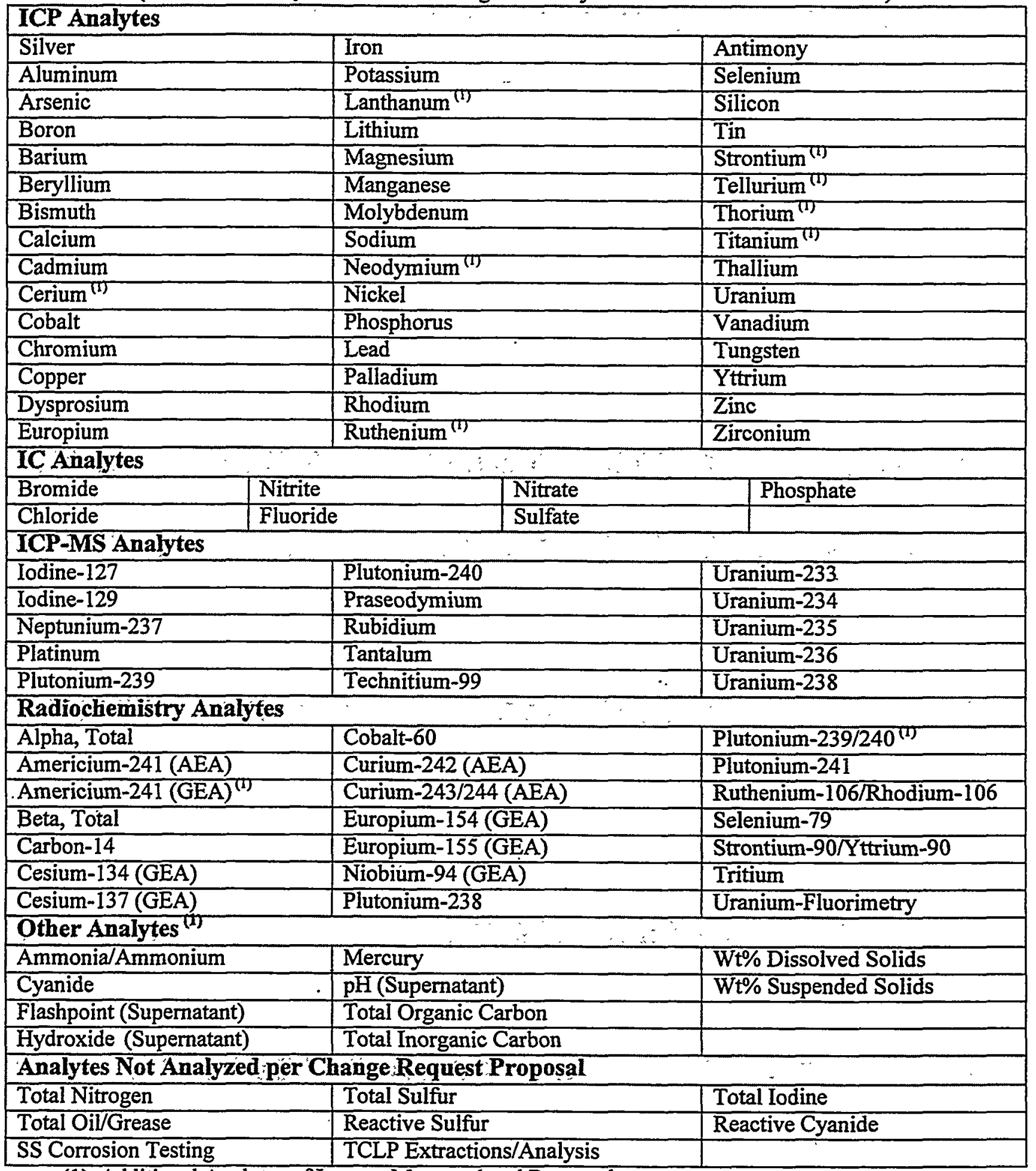

(1) Additional Analytes of Interest Measured and Reported 
Eonteslled lorcument

PNNL Test Plan

Document No.: BNFL-TP-29953-031

Rev. No.: 1

only working Copy

Title: C-104 Sample Compositing

\begin{tabular}{|l|}
\hline Work Location: 325/SFO \\
\hline Author: Paul Bredt \\
\hline Use Category Identification: Reference \\
\hline $\begin{array}{l}\text { Identified Hazards: } \\
\text { Radiological }\end{array}$ \\
$\begin{array}{l}\text { Hazardous Materials } \\
\text { Physical Hazards }\end{array}$ \\
- Hazardous Environment \\
\hline Other:
\end{tabular}

Page 1 of 6

Effective Date: Upon Final Signature

Supersedes Date: New

Required Reviewers:

$\mathrm{X}$ Author

XTechnical Reviewer

XRPL Manager

$X$ Project Manager

XRPG Quality Engineer

BNFL

Are One-Time Modifications Allowed to this Procedure? $X$ Yes _ No

NOTE: If Yes, then modifications are not anticipated to impact safety. For documentation requirements of a modification see SBMS or the controlling Project QA Plan as appropriate.

On-The Job Training Required? Yes or $: \frac{\mathrm{X} ! \text { No }}{: !}$

\section{FOR REVISIONS:}

Is retraining to this procedure required? Y__ Yes No

Does the OJT package associated with this procedure require revision to reflect procedure changes?

Yes No $\mathrm{X}$ N/A

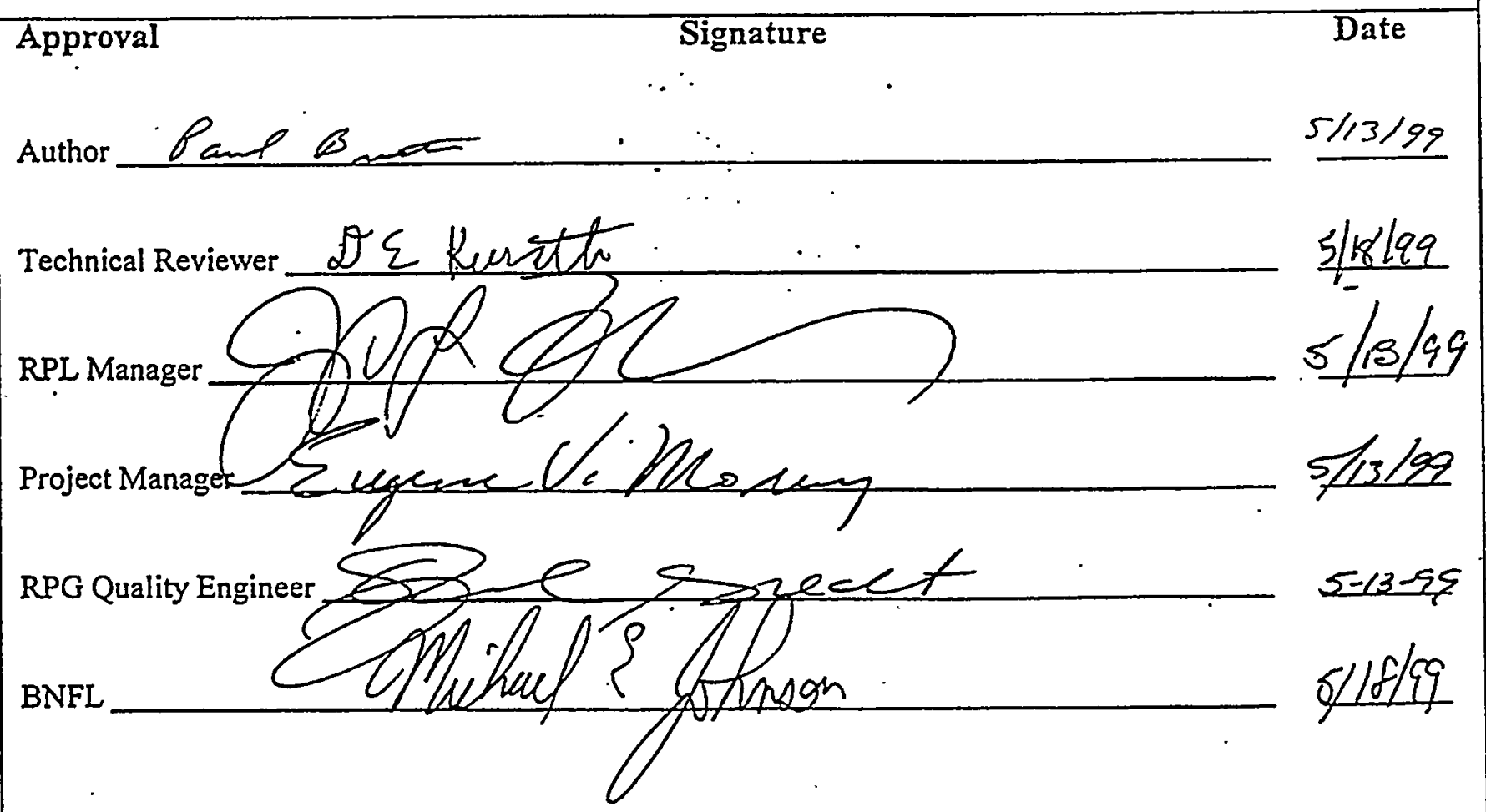




\section{PNNL Test Plan Supplemental Signature Page}

Document No.: BNFL-29953-031

Rev. No.: 1

Title: C-104 Sample Compositing

Work Location: 325/SFO

Page: Supplemental

Author: Paul Bredt

Use Category Identification: Reference

Identified Hazards:

Radiological

Hazardous Materials

Physical Hazards

Hazardous Environment

Other.

Effective Date: Upon Final Signature

Supersedes Date: New

Supplemental Reviewers:

X SFO Manager

Building Manager

Radiological Control

ES\&H

$\because \quad$. Other

Approval

Signature

Date

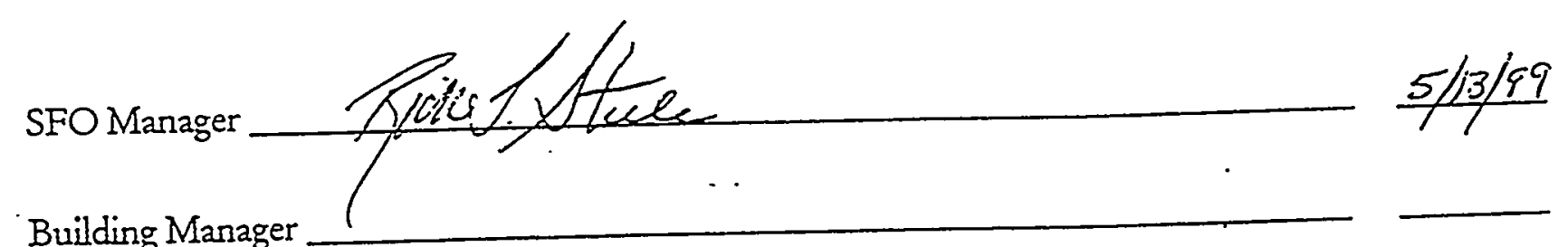

Building Manager

Radiological Control

ES\&H

Other

$\because$

Other

Other 


\section{Applicability}

This Test Plan describes work to be performed under Task 2.01, LAW and HLW Feed Characterization. This work is defined under BNFL letter W375-98-0018 dated September 29, 1998. Approximately 1.7 L of material from Tank 241-C-104 have been transferted from the 222-S laboratory to the $325 \mathrm{HLRF}$. All of this material is to be used to prepare a C-104 composite.

Approximately $250 \mathrm{ml}$ of the homogenous composite are to be collected for delisting and permitting activities. These samples will be withdrawn from the composite in a manner which will provide representative samples for chemical, radiochemical, and physical testing. To support the delisting and permitting, this test plan will generate samples that will allow measurement of chemical properties of the waste that are both precise and accurate. Integrity of the subsamples will be maintained consistent with prior sampling and storage history. No preservation or temperature control of the subsamples are planned. Sampling protocols in SW-846 are not strictly applicable since these protocols are targeted at sampling in the field.

Following collection of the homogenous delisting and permitting samples, all remaining standing liquid will be removed from the composite. This liquid will be submitted for additional characterization activities. The remaining solids will only contain a limited amount of interstitial liquid.

\section{Objectives}

The objectives of this test plan are the following:

1) Homogenize the C-104 samples shipped from $222-S$ to 325

2) Subsample the homogenous composite for chemical and radiochemical characterization

3) Decant all standing liquid for additional chemical and radiochemical characterization

4) Subsample solids for solids washing and leachịng studịies

Note
1. Sample material is not to contact plastic as this could complicate organic analyses. This precludes the
use of plastic transfer pipettes.
2. Use "Qorpak" jars with TFE-lined closures. These bottles/closures do not introduce contamination to
the samples.

\section{Quality Control}

Quality control has been implemented in the work instructions.

Since this document will be used to record an experimental process, markups as specified in the RPL Operations manual section 16.6 will be allowed. The staff member performing the change initials markups to this Test Plan. The Cognizant Scientist overseeing the work initials and dates changes to the Test Plan. Changes miade by the Cognizant Scientist do not require additional reviews or approvals. If changes occur to multiple pages then the Cognizant scientist shall note the effected pages and initialize the note. Superseded text shall be lined out, but not obscured, initialed and dated. 


\section{M\&TE List:}

\begin{tabular}{|c|c|c|c|c|}
\hline \multirow[t]{2}{*}{ Balance 1: } & Calib ID & $384-06-01-004$ & Calib Exp Date $8 / 99$ & \\
\hline & Location & $601 r_{(21}$ & & \\
\hline \multirow[t]{2}{*}{ Balance 2: } & Calib ID & $388-06-01-020$ & Calib Exp Date $8 / 99$ & \\
\hline & Location & c-cell & & \\
\hline \multirow[t]{2}{*}{ Thermocouple: } & Calib ID & $\begin{array}{l}2531325-416 \\
202931\end{array}$ & Calib Exp Date $5 / 01$ & \\
\hline & Location & 601 & Thermocouple type $K$ & \\
\hline \multirow[t]{2}{*}{ Digital Thermometer: } & Calib ID & 2531 & Calib Exp Date $\quad 5 / 00$ & \\
\hline & Location & 601 & & \\
\hline
\end{tabular}

1) The composite is to be prepared in a 3L stainless steel vessel. Secondary containment will be used to allow recovery from a possible breach of a $3 \mathrm{~L}$ vessel or failure of the tap valve. The recommended parts for the kettles are listed below. Viton O-rings are to be used for sealing the vessel. No grease is to be used. All components (including the valve) are to be rinsed with methanol and then placed in a $102^{\circ} \mathrm{C}$ oven for 12 hours. The valve (packed with ultra high molecular weight polyethylene) is lightly greased with silicone. Since the valve will only see limited use, removing this grease with the methanol rinse should not effect its performance. The system is then to be assembled and leak tested using deionized water. Do not use teflon tape to assemble the vessel.

\begin{tabular}{|l|l|l|}
\hline Description & Part & Vendor \\
\hline UHMWPE packed $3 /^{3 \prime}$ Ball Valve & SS-63ES12 & Seattle Valve and Fitting \\
\hline $\begin{array}{l}\text { 5'ID } 9.87^{\prime \prime} \text { pipe nipple with 6.75" } \\
\text { Comflat flange }\end{array}$ & FNF0500 & Varian \\
\hline $6.75^{\prime \prime}$ blank off flange & F06750000NC4 & Varian \\
\hline $6.75^{\prime \prime}$ viton gasket & FG0675VU & Varian \\
\hline Nut and boIt set & FB0600C06 & Varian \\
\hline Clamping ring & Z12,171-1 & Sigma-Aldrich \\
\hline 3/4" swagelok to pipe thread & SS-12-TA-1-12 & Seattle Valve and Fitting \\
\hline Stir rod & $14-500-18$ & Fischer \\
\hline
\end{tabular}


2) Weigh the sample jars listed below to $\pm 0.01 \mathrm{~g}$. Transfer all material from the jars to the mixing

$$
\begin{aligned}
& R / G= \text { red liguid } \\
& \text { Graen } \\
& \text { settledsolids }
\end{aligned}
$$
vessel. If necessary, use supernatant from the jars or vessel to rinse the solids into the vessel.

Reweigh the empty jars and record the mass to $\pm 0.01 \mathrm{~g}$ in the space provided.

\begin{tabular}{|c|c|c|c|c|}
\hline Sample Label & Mass (Full) & Mass (Empty) & Mass Transferred & \\
\hline $16273 \cdots$ & 273.768 & .123 .722 & $i 50.046$ & \\
\hline $16274 \cdot c h \mathrm{ch} / \mathrm{s}$ & 290.118 & .132 .480 & 157.638 & $R l$ \\
\hline 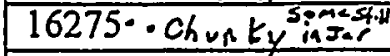 & .301 .270 & $-124,835$ & 176.435 & 15 gn \\
\hline $16276 \cdots$ & 284.182 & $-126 . q>0$ & 157.212 & $R / G$ \\
\hline 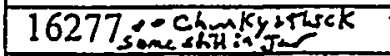 & 302,310 & .139 .660 & 162.650 & Nist. lig liquid \\
\hline 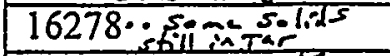 & $301,5 / 2$ & -136.640 & 164872 & $R / G$ \\
\hline $16279 \cdot 1$ soll intar sols & 288,623 & .138 .978 & 149645 & $R / G$ \\
\hline $16280 \cdots$ & 266,863 & .125 .061 & 141.802 & {$[8]_{6}$} \\
\hline $16281 \cdots$ & 270.904 & .128 .296 & 142608 & RR $J G$ \\
\hline 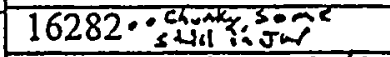 & 299.436 & 139.091 & 160.345 & no standing ligso.S \\
\hline $16283 \cdot \cdot$ stilspme solids & 284,721 & .125 .549 & 159.172 & $8 / 6$ \\
\hline $162840 \cdot$ chmky $_{4}$ & 288.493 & .128 .242 & 160.251 & $R / 6$ \\
\hline $16285 \cdots$ Chugks & 283,223 & .135 .922 & 324.301 & (E) $b$ \\
\hline $16286 \cdots$ & 281.264 & .129 .612 & 151.652 & $\sqrt{R} / G$ \\
\hline
\end{tabular}

$$
\text { initial tre.sfer on 6/17/99 }
$$

examined 16281 , no wisibh -rganic kyer

3) The goal of this step is to homogenize the sample using as little force as possible. Stir the sample by slowly increasing the motor speed until the solids are mobilized. Given this work is being conducted in a steel vessel, observations need to be made with the lid off the vessel. Stir for a minimum of one hour. Record the hot cell temperature. S fartad stirer 8:304.4 6/23/89

$$
\text { collectald stes stiving } 6 / 23 / 99 \text { Temperature } 337{ }^{\circ} \mathrm{C}
$$

4) Clearing the valve: While the solids are mobilized, coHect $-50 \mathrm{ml}$ of sample in a clean jar. This fraction is probably high in solids due to the geometry of the vessel, so return this sample to the vessel and continue to stir the vessel.

5) Collect $3 \sim 100 \mathrm{ml}$ samples in volume-graduated tared bottles listed below by removing material using the $3 / 4$ " ball valve located on the bottom of the vessel. Sufficient sample is to be collected in each jar as to minimize headspace in the jars. Weight the full bottles to $\pm 0.01 \mathrm{~g}$ and record the masses below.

\section{C-104 COMP A}

$$
\text { collowted last sample at tropks }
$$

$$
\text { C-104 COMP B } 6 / 23 / 49
$$

$\begin{array}{ll}\text { Total } & \frac{303.839}{133.4967 \mathrm{~g}} \\ \text { Tare } & \frac{13.4072 \mathrm{~g}}{70.342}\end{array}$

\section{C-104 GL}

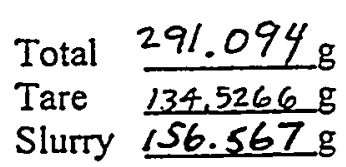

Total $302.685_{g}$

Tare $133,7596 \mathrm{~g}$

Slurry $\frac{89}{168.92586 / 23 / 99}$

6) Turn off the stirring motor, record the date and time. Cover the vessel using a blank flange.

Day 6/23/99. Time 10:00an

7) Allow C-104 COMP A, C-104 COMP B, and C-104 GL to settle for a minimum of 16 hours.

$\left\{\begin{array}{l}\text { allowed vessol t suttle until } 6 \text { 6/2//49. Remound stanlingliguid } \\ \text { and used to rinse the } 6 \text { jars thet still containd solids } \\ \text { PR } \beta 6 / 23 / 99\end{array}\right.$

- very litth standig liguid (<5os) on 6/24/990 9:00 an /46 
8) Record the date and time, and total volume of the slurries and volume of the settled solids in C-104 COMP A, C-104 COMP B, and C-104 GL.

$$
\text { Day } 7 / 2 / 99 \text { Time S:45: }
$$

\section{C-104 COMP A}

Total $\frac{117}{194} \mathrm{ml}$ का s. $^{9^{\mathrm{t}} / 0}$

\section{C-104 COMP B}

Total $\frac{120}{107} \mathrm{ml} \mathrm{s}^{42^{2}}$
C-104 GL

9) If the volume percent settled solids in the 3 samples are within $\sim 10 \%$, then the samples are representative of the whole composite and proceed to step 10 . If the volume percent settled solids vary by much more than $10 \%$, then return the slurry samples in jars C-104 CONIP A, C-104 COMPP $\mathrm{B}$, and $\mathrm{C}-104 \mathrm{GL}$ to the kettle, increase the stirring rate and repeat steps 3 through 9. Record new information and attach to this test plan.

10) Tum the stirrer on and allow the system to stir for $\sim 10$ minutes. While the stirrer is on, collect all the remaining material in $500 \mathrm{ml}$ jars as labeled below. It is possible that up to 3 jars may be required. Record the time and date.

$$
\text { Day } 7 / 2 / 99 \text { Time 9:25 am }
$$

\section{C-104 COMP C}

Total $951.16 \mathrm{~g}$

Tare $345.4623 \mathrm{~g}$

Slurry $605.698 \mathrm{~g}$
C-104 COMP D.

$$
\begin{aligned}
& \text { Total } \frac{955.90 \mathrm{~g}}{347.3564 \mathrm{~g}} \\
& \text { Tare } \frac{34.54 \mathrm{~g}}{608.54} \\
& \text { Slurry }
\end{aligned}
$$

\section{C-104 COMP E}

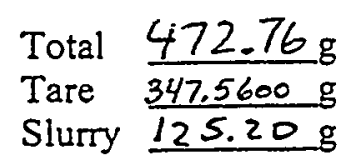

11) Allow samples $C-104$ COMP $C, C-104$ COMP D, and $C-104$ COMP $E$ to settle for at least 3 days then transfer all standing liquid on samples C-104 COMPP C, C-104 COMP D, C-104 COMP E, and C-104 GL to $250 \mathrm{ml}$ jars as labeled below. This transfer is to be conducted by decanting or using clean glass pipettes. It is possible that up to 3 jars may.be required. Record the time and date.

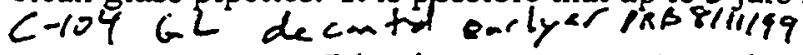
Day $8 / 11 / 99$ Time 11:45 $\mathrm{cm}$

\section{C-104 SUP A}

\section{Total $424.51 \mathrm{~g}$}

Tare $248.8005 \mathrm{~g}$

Slurry

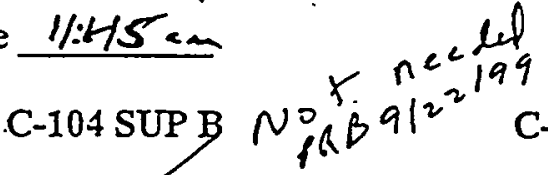

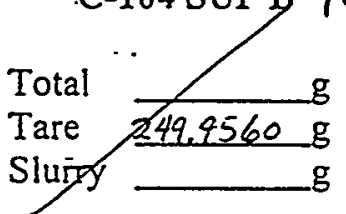

\section{C-}

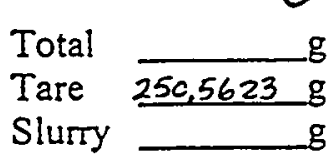

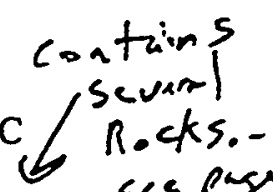

sec paye

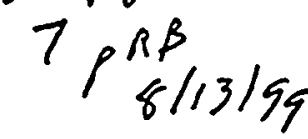

12) Transfer sample C-104 COMP A, C-104 COMIP B, C-104 GL, C-104 SUP A, C-104 SUP B, and C-104 SUP C to the SAL with a chain of custody.

13) Add $50 \mathrm{~mL}$ of $0.01 \mathrm{M} \mathrm{NaOH}$ to the vessel and agitate.

$$
\begin{aligned}
& \begin{array}{c}
c-1045-1 A \text { after a dition of sp from } C-104 G L=264.912 \mathrm{~g} \\
\text { PAB } 7 / 29199
\end{array}
\end{aligned}
$$

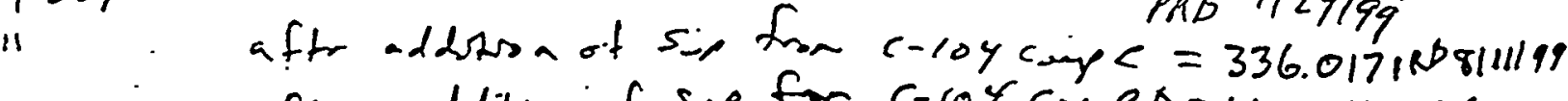

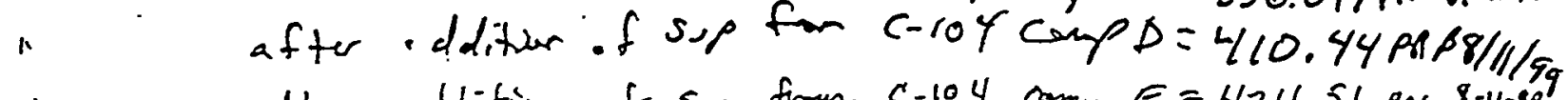

$$
\begin{aligned}
& 11 \text { atter addition of Sup from } c-104 \text { comp } E=424.51 \text { Rec 8-11-999 }
\end{aligned}
$$

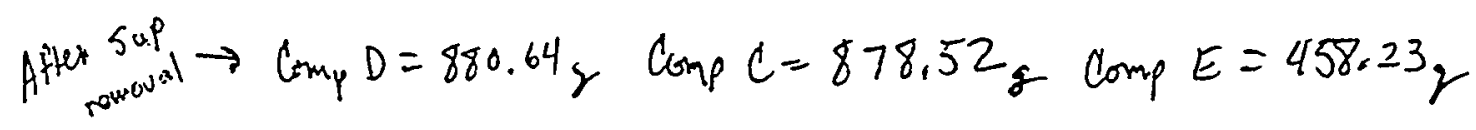



vs ed $0.01 M N$ O lt to Rinds Jus s (origin 1 jars firm $222-\xi$ )
BNFL-29953-031 Rev. 1
Page 6 of 6 than ad ed to cess 1 .

Page 6 of 6

PRS $7 / 2 / 99$

14) Drain the vessel into a $250 \mathrm{ml} \mathrm{jar}$ labeled $C-104 \mathrm{RIN}$.

C-104 RUN

Total $\frac{372.187 g}{249.5728}$

Slurry $\lcm{22.674 \mathrm{~g}}$

15) Add another $50 \mathrm{~mL}$ of $0.01 \mathrm{M} \mathrm{NaOH}$ to the vessel and agitate.

$$
\begin{aligned}
& 23 k 0 \\
& 160 \\
& 111 \\
& 40 \mathrm{glnok}
\end{aligned}
$$

16) Drain the vessel into $C-104 R I N$.

C-104 RIV

Total $\frac{521.96 \mathrm{~g}}{249.5128 \mathrm{~g}}$
Tare
Slurry $272.447 \mathrm{~g}$

17) Place sample jars C-104 COMP C, C-104 COMPP D, C-104 COMP E, and C-104 RIN in a secondary container and retain for CUF studies.

$$
\begin{aligned}
& 0.01 \mathrm{M} \mathrm{N} \mathrm{OH} \\
& \text { Solon } \\
& 0.01 \mathrm{M}: \mathrm{in}^{\mathrm{N}}-01 \mathrm{H} \\
& \text { Sh+ pleB } 7 / 3 / 49 \\
& 0.001 \text { vols } \cdot \frac{40 \mathrm{z}}{\text { moke }}=0.04 \mathrm{~g}
\end{aligned}
$$

Using DI in $\$ 201,42.80 .0664^{\circ} \quad N-O H$ Fisher Binal Lot $\$ 961969$

and pluck in plastic volumetric Flask. Brought op to 100 at. $P R B D / 2 / 99$

Solution 42

$0.0727 \mathrm{~g} N$ off in $100 \mathrm{all} \mathrm{H}_{2} \mathrm{O}$

ch b:

$1 / 2199$

Ringed vassal again with another another double shot of $0.01 \mathrm{MNaOl}$.

C-10\% RIT Z

$$
\begin{gathered}
\text { tore } \frac{249.5786}{240.49} \mathrm{~g} \\
\text { sire }
\end{gathered}
$$

r 8 rocks $-1 / 4$ " in Bottom of $v=$ sse after training. Kullow/Brawn Transferred Rocks to

$$
\text { C-104 UPC }
$$

total $\frac{265.908}{250.5623} \mathrm{~g}$
tore $\frac{25.357 \mathrm{~g}}{15.345}$
rocks 


\section{PNNL Test Plan}

Document No.: BNFL-29953-080

Rev. No.: 1

Title: Organic Extraction of C-104 Samples and sub-sampling for VOA, Headspace, and Anions

Work Location:

325/SFO, 325/general labs; 329/general labs

Author: Michael W. Urie

Use Category Identification: Reference

Identified Hazards:

x Radiological

$x$ Hazardous Materials

- Physical Hazards

- Hazardous Environment

- Other:
Page 1 of 17

Effective Date: Upon final signature Supersedes Date: New

Required Reviewers:

$\underline{X}$ Technical Reviewer $\underline{X}$ Project Manager

Building Manager $\underline{X}$ RPL Manager

Radiological Control $X$ SFO Manager

ES\&H

$\underline{\bar{X}}$ Quality Engineer

X AO\&AM Manager

Are One-Time Modifications Allowed to this Procedure?

$$
\underline{X} \text { Yes }- \text { No }
$$

NOTE: If Yes, then modifications are not anticipated to impact safety. For documentation requirements of a modification see SBMS or the controlling Project QA Plan as appropriate.

On-The Job Training Required? _ Yes or _ $\mathrm{X}$ No FOR REVISIONS:

Is retraining to this procedure required? _ Yes $X$ No

Does the OJT package associated with this procedure require revision to reflect procedure changes? _ Yes_ No $\underline{X}$ N/A

\section{Approval}

Author (VOA, SVOA)/Reviewer

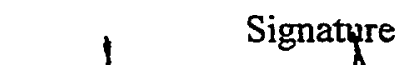

Signatyre

rer

Author (PCB, Headspace)/Reviewer
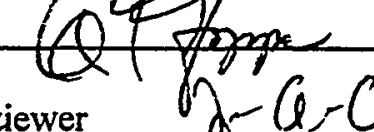

Author (Dioxins/Furans, Anions)/Reyiewer

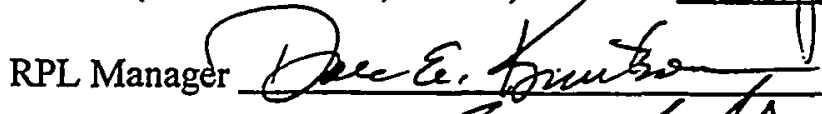

SFO Manager Stele

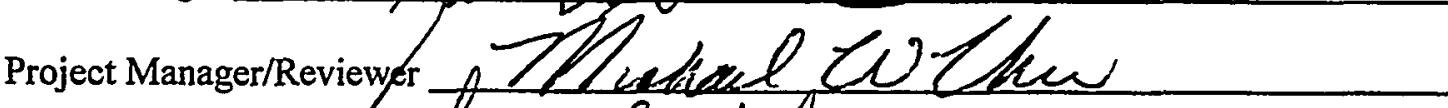

Project Manager/Reviewer f

AO\&AM Manager

conth

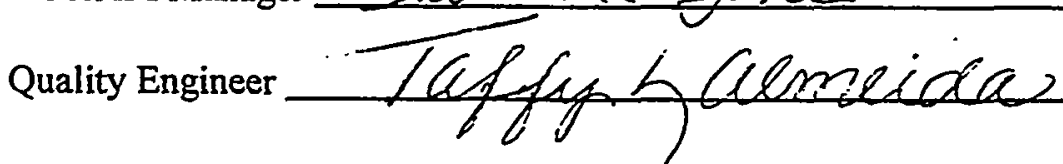

Date

6-5-00

$6-5-00$

$6.9-60$

$6 / 6 / 00$

$6 / 6 / 00$

$6-5-00$

$6-5-00$

$6 / 5 / 00$ 


\section{Applicability}

This Organic Extraction Test Plan describes work to be performed under Test Plan TP-29953-030, Inorganic, Organic and Radiochemical Characterization of C-104 Samples. These samples are slurries, which contain solids, and decanted liquid. Together these samples provide the starting material for the organic characterization of the "as received" materials. Per the TP-29953-030, two bottles containing about 340 grams of slurry and one jar containing about 175 grams of supernatant will be sub-sampled for VOA, headspace analysis, organic anions, SVOA, pesticide/PCB, and Dioxin/Furan analysis, as well as inorganic and radiochemistry analysis specified in the test plan. Sub-sampling and dilutions for VOA and headspace analysis will be performed prior to beginning extractions so as not to contaminate these sub-samples with solvent vapors.

Based on the history of the samples, and the limited quantities available, exceptions are being taken to the preservation, temperature control, sample size, and hold time requirements specified by SW- 846 protocols. The choice of spiking solutions and extraction solvents is based upon SW-846 methods $8270 \mathrm{C}, 8081 \mathrm{~A} / 8082$ and 8290 guidelines, where applicable.

This revision provides final documentation for the actual work performed for phase separation of the C-104 slurry, sub-sampling activities for the VOA and Headspace analyses, and the organic extraction process performed for preparing the SVOA, PCB, and Dioxin/Furan samples.

\section{Hazards Assessment and Mitigation}

The radioactive work conducted under this Test Plan is comprised of analytical organic analysis preparative operations that have been conducted routinely in the RPL and 329 Facilities. The organic extractions with small quantities of methylene chloride or methylene chloride/acetone mixtures have been performed in the Shielded Analytical Laboratory (SAL) many times and are included as a standard preparative activity on the RPL Analytical Service Request. The organic solvent extraction operations are included in the SAL work authorization. Since all of the analytical preparative operations fall within current work authorizations, no further assessment of the hazards is detailed in this Test Plan.

\section{Quality Control}

Per TP-29953-030, quality control is governed by PNNL's web-based Quality Assurance Planning Subject Area, "Conducting Analytical Work in Support of Regulatory Programs". The organic analyses will be performed in duplicate using a sample size that will closely meet regulatory reporting level for waste material. Sample sizes are specified in Test Plan TP-29953-030. Surrogate spike compounds will be added to the sample, sample duplicate, and matrix spikes in order to provide information on analyte recoveries. Separate laboratory control samples (LCS) will be prepared outside the hot-cell.

Integrity of the sub-samples and processed extracts distributed throughout the laboratory will be maintained by chain-of-custody documentation. The Task Manager shall approve changes to this Test Plan (initialed markups are allowed).

\section{Work Instructions}

An extraction scheme for the SVOA extraction activity is provided in Figure 1. Extraction schemes for $\mathrm{PCB} /$ pesticide and dioxin extractions are provided in Figures 2 and 3, respectively.

Total dissolved solids of the supernatant and weight percent solids of the centrifuged solids will be determined prior to sub-sampling and extracting. 
The extractions of these C-104 HLW samples will be performed in the Shielded Analytical Laboratory within the 325 facility.

\subsection{Total Dissolved Solids and Weight Percent Solids Determination}

Because these samples may contain reduced iron or other magnetically separable particles, a magnetic stir-bar and magnetic stir table should not be used. A better approach is to perform the stirring with an impeller-type stirrer, such as a Teflon coated spatula rotated by a variable speed drill. After a few minutes of stirring, and once the solids appear to be suspended, a 1-g to 3-g aliquot is placed in a tared graduated centrifuge tube, weighed, and centrifuged at 1000 RPM for approximately one hour. After centrifuging, note and record the volume of both the liquid and the solids in the tube. Decant the liquid into a tared beaker, weigh and dry at $105^{\circ} \mathrm{C}$ overnight. Weigh the beaker after at least 12 hours of drying to determine the total dissolved solids for the supernatant. Weight percent solids determination will be performed on the centrifuged solids, remaining in the centrifuge tube, in accordance with PNL-ALO-504.

\subsection{Separation of the Wet Solids from the Slurry}

Centrifugation of the slurry (i.e., C104 Comp A and C104 Comp B) may be more convenient than filtration for the separation of the wet solids from the slurry. In order to centrifuge the $120-\mathrm{mL}$ jars, they must first be balanced to $\pm 1 \mathrm{~g}$. Weigh each jar and transfer the appropriate quantity of liquid from the heavier jar to the lighter jar to balance them. Place the jars in clean polyethylene sleeves, and centrifuge at no greater than 1000 RPM for 1 hour. As a precaution, it is prudent to perform a "dry-run" first, using balanced jars containing approximately $100 \mathrm{~mL}$ of deionized water, and centrifuging at 1100 RPM. After the jars containing the slurries have been centrifuged, carefully remove them from the centrifuge and the plastic sleeves. Carefully decant the supernatant into a clean jar or combine with the jar containing C-104 supernatant (i.e., container C104 SUP. A) if room is available in the container. Weigh the jar containing the wet centrifuged solids, and record this weight on the benchsheet. In the event the total quantities of supernatant and wet solids are less than those listed in test plan BNFL-29953-30, contact Michael W. Urie, 376-9454.

\subsection{Sub-sampling for.VOA and Headspace analysis}

VOA and headspace aliquots shall be made prior to introducing methylene chloride, or other solvents, into the hot-cells.

Headspace samples should be aliquotted into clean 10 -mL headspace vials and sealed with a septa-lined cap immediately afterward. A $1-\mathrm{mL}$ supernatant sample, sample duplicate, sample triplicate and blank will be prepared for each sample as described in Test Plan TP-29953-030, Table 2. (Note: The sample triplicate is an additional sub-sample not identified in TP-29953-030.) A 1-mL supernatant matrix spike and matrix spike duplicate will also be aliquotted at this time. The headspace vials should be tared on an analytical balance, and each $1-\mathrm{mL}$ aliquot weighed and recorded, so that the density of the supernatant can be determined during this step. Additionally, 50-microliter aliquots each of the supernatant sample, sample duplicate, sample triplicate, matrix spike, and matrix spike duplicate shall also be prepared to permit quantitation of analytes that may be outside the calibration range for a $1-\mathrm{mL}$ sample size.

VOA samples should be aliquotted into clean 40-mL VOA vials and sealed with a septa-lined cap immediately afterward. A 2-mL supernatant sample, sample duplicate and blank will be prepared for each sample as described in Test Plan TP-29953-030. A I-mL supernatant matrix spike, and matrix spike duplicate will also be aliquotted at this time. Additionally, 50-microliter aliquots of each the supernatant sample, sample duplicate, matrix spike, matrix spike duplicate shall also be prepared to permit quantitation of analytes that maybe outside the calibration range for a 2-mL sample size. Half gram aliquots of the wet centrifuged solids will be aliquotted into clean $40-\mathrm{mL}$ VOA vials, diluted with organic-free water to a volume of $5 \mathrm{~mL}$ and sealed immediately with a septa-lined cap. The aliquots 
for the VOA MS and MSD shall be 0.25-g rather than the 0.5-g aliquots used for the sample and duplicate. In a like manner, a second set of wet centrifuged solids will be aliquotted using a $50-\mathrm{mg}$ sample size for each the sample, duplicate, MS and MSD.

VOA and headspace samples will be transferred from the hot-cell immediately after preparation. For further guidance or questions regarding VOA sub-sampling contact George S. Klinger, 372-0448. For further guidance or questions regarding headspace sub-sampling contact Eric W. Hoppe, 376-2126.

\subsection{Extraction samples for SVOA, PCB/pesticides and Dioxins analysis}

General Comments:

The quantities of the sample, sample duplicate, matrix spike, and matrix spike duplicate are given in Table 2 of Test Plan BNFL-29953-030 and restated in Section 2.1.

Teflon separatory funnels, with FEP caps, are used for the liquid-liquid extraction processing and teflon centrifuge tubes are used for the subsequent solids ultrasonic processing.

Phosphoric acid is used to adjust the $\mathrm{pH}$ prior to extraction of the liquids, as appropriate.

A small $(0.5 \mathrm{ml})$ portion of the liquid is potentiometricly titrated to determine the quantity of phosphoric acid required to adjust the $\mathrm{pH}$ of the sample. The amount of precipitate formed during acidification will be evaluated and the precipitate extracted separately, if required.

Spiking solutions will be added to the sample prior to extraction. If solids formed as a result of $\mathrm{pH}$ adjustment warrant a separate extraction step, additional spikes will not be added as these extracts will be recombined with the "like" phase extracts.

The nominal MDLs for liquids and solids are shown in Tables 1 and 2, respectively. The surrogate spikes and quantities added are shown in Table 3. The appropriate spiking materials shall be provided by $\mathrm{G}$. Klinger for SVOA, by E. Hoppe for pesticides/PCB, and J. Campbell for dioxins/furans.

\begin{tabular}{|l|c|c|}
\hline \multicolumn{3}{|c|}{ Table 1 Liquid portion HLW organic analysis MDLs } \\
\hline Analysis & MDL (ppb, 1 L water) & MDL (ppb, 25 mL sample) \\
\hline Semivolatiles & 10 to 25 & 400 to 1000 \\
\hline Pesticides and PCBs & 0.1 to 1 & 4 to 40 \\
\hline Dibenzodioxins and Dibenzofurans & $1 \times 10^{-4}$ to $1 \times 10^{-3}$ & $4 \times 10^{-3}$ to $4 \times 10^{-2}$ \\
\hline
\end{tabular}

\begin{tabular}{|l|c|c|}
\hline \multicolumn{3}{|c|}{ Table 2 Solid portion HLW organic analysis MDLs } \\
\hline Analysis & MDL (ppm, 1 g solid) & MDL (ppm, 5 g sample) \\
\hline Semivoiatiles & 10 to 25 & 2 to 5 \\
\hline Pesticides and PCBs & 0.1 to 1 & 0.02 to 0.2 \\
\hline Dibenzodioxins and Dibenzofurans & $1 \times 10^{-4}$ to $1 \times 10^{-3}$ & $2 \times 10^{-5}$ to $2 \times 10^{-4}$ \\
\hline
\end{tabular}




\begin{tabular}{|c|c|c|}
\hline \multicolumn{3}{|c|}{ Table 3 Surroagte Spike Compounds and Levels added to Samples } \\
\hline Analysis. & Spike Compounds & Amounts Added (ug) \\
\hline Semivolatiles & $\begin{array}{c}\text { phenol- } d_{5} \\
\text { 2-fiuorophenol } \\
\text { 2-ctilorophenol-d } d_{4} \\
\text { 2,4,6-tribromophenol } \\
\text { 1,2-dichlorobenzene- } d_{4} \\
\text { nitrobenzene-d } \\
\text { 2-fluorobiphenyl } \\
\text { p-terphenyl- } d_{14}\end{array}$ & $\begin{array}{l}75 \\
75 \\
75 \\
75 \\
50 \\
50 \\
50 \\
50\end{array}$ \\
\hline Dibenzodioxins and Dibenzofurans & $\begin{array}{c}{ }^{13} \mathrm{C}_{12}-2,3,7,8 \mathrm{TCDD} \\
{ }^{13} \mathrm{C}_{12}-2,3,7,8 \mathrm{TCDF} \\
{ }^{13} \mathrm{C}_{12}-1,2,3,7,8 \text { PeCDD } \\
{ }^{13} \mathrm{C}_{12}-1,2,3,7,8 \text { PeCDF } \\
{ }^{13} \mathrm{C}_{12}-2,3,4,7,8 \text { PeCDF } \\
{ }^{13} \mathrm{C}_{12}-1,2,3,4,7,8 \mathrm{HXCDD} \\
{ }^{13} \mathrm{C}_{12}-1,2,3,6,7,8 \mathrm{HXCDD} \\
{ }^{13} \mathrm{C}_{12}-1,2,3,4,7,8 \mathrm{HXCDF} \\
{ }^{13} \mathrm{C}_{12}-1,2,3,6,7,8 \mathrm{HXCDF} \\
{ }^{13} \mathrm{C}_{12}-1,2,3,7,8,9 \mathrm{HXCDF} \\
{ }^{13} \mathrm{C}_{12}-2,3,4,6,7,8 \mathrm{HXCDF} \\
{ }^{13} \mathrm{C}_{12}-1,2,3,4,6,7,8 \mathrm{HpCDD} \\
{ }^{13} \mathrm{C}_{12}-1,2,3,4,6,7,8 \mathrm{HpCDF} \\
{ }^{13} \mathrm{C}_{12}-1,2,3,4,7,8,9 \mathrm{HpCDF} \\
{ }_{13} \mathrm{C}_{12}-\mathrm{OCDD}\end{array}$ & $\begin{array}{l}0.05 \\
0.05 \\
0.05 \\
0.05 \\
0.05 \\
0.05 \\
0.05 \\
0.05 \\
0.05 \\
0.05 \\
0.05 \\
0.05 \\
0.05 \\
0.05 \\
0.1\end{array}$ \\
\hline Pesticides and PCBS & $\begin{array}{l}\text { tetrachloro-m-xylene } \\
\text { decachlorobiphenyl }\end{array}$ & $\begin{array}{l}0.040 \\
0.040\end{array}$ \\
\hline
\end{tabular}

\subsection{Extraction of the supernatant portion of the $\mathrm{HLW}$ samples}

Extractions for the SVOA supernatant sample and duplicate are performed on $20-\mathrm{mL}$ aliquots, with the extractions for the SVOA matrix spike and matrix spike duplicates being performed on $10-\mathrm{mL}$ aliquots. Extractions for all pesticides and PCB supernatant samples are performed on 10-mL aliquots. And, extractions for dioxins/furans supernatant sample and duplicate are performed on 15-mL aliquots, with the extractions for the dioxins/furans matrix spike and matrix spike duplicate being performed on $7.5-\mathrm{mL}$ aliquots. The quantity of matrix spike used is given in Table 4. Extraction blanks shall be prepared using the same quantity of organic-free water as the quantity of supernatant sample. Stepwise instructions for performing the extractions are given in Sections 6.1, 7.1 and 8.1.

\section{Semivolatiles}

As shown in Figure 1, the supernatant portion of the as received sample is diluted with $25 \mathrm{~mL}$ of $0.01 \mathrm{~N}$ $\mathrm{NaOH}$ (prepared from organic-free water) prior to extraction. Following dilution the supernatant sample is extracted three times with equal portions of methylene chloride.

The superantant sample is then $\mathrm{pH}$ adjusted by slow drop-wise addition of phosphoric acid while the sample is cooled in an ice-bath during the acidification. The pH-adjusted supernatant sample is extracted three times with equal portions of methylene chloride.

If during the acidification process any solids are formed at a relative quantity $>1 \%$ by volume, the solids are separated, desiccated with sodium sulfate, and ultrasonic extracted three times using equal portions of methylene chloride.

All SVOA extracts from the supernatant portion of the as received sample are combined and concentrated to $1 \mathrm{~mL}$ outside the hot-cells. 


\section{$\underline{\text { Pesticides/PCB }}$}

As shown in Figure 2, the supernatant portion of the as received sample is diluted with $25 \mathrm{~mL}$ of $0.01 \mathrm{~N}$ $\mathrm{NaOH}$ (prepared from organic-free water) prior to extraction. Following dilution the supernatant sample is extracted three times with equal portions of methylene chloride.

The supernatant sample is then $\mathrm{pH}$ adjusted by slow drop-wise addition of phosphoric acid while the sample is cooled in an ice-bath during the acidification. The pH-adjusted supernatant sample is extracted three times with equal portions of methylene chloride.

If during the acidification process any solids are formed at a relative quantity $>1 \%$ by volume, the solids are separated, desiccated with sodium sulfate, and ultrasonic extracted three times using equal portions of a 1:1 methylene chloride/acetone mixture.

All extracts from the supernatant portion of the as received sample are combined and concentrated to $1 \mathrm{~mL}$ outside the hot-cells.

\section{Dioxins/Furans}

Adjustment of the $\mathrm{pH}$ is presumed not to be necessary for the dioxin/furan extractions. To dilute the sample, $25 \mathrm{~mL}$ of $0.01 \mathrm{~N} \mathrm{NaOH}$ (prepared from organic-free water) will be added to the sample prior to extraction. As shown in Figures 3, a supernatant sample is extracted (liquid-liquid) three times with equal portions of methylene chloride. The extracts from the supernatant portion of the as received sample are combined and concentrated to $1 \mathrm{~mL}$ outside the hot-cells.

\subsection{Extraction of the centrifuged solids portion of the HLW samples}

The solid sample and duplicate will be extracted using $5 \mathrm{~g}$ of the solids portion of the as received sample. A matrix spike and spike duplicate will be extracted using $2.5 \mathrm{~g}$ of sample. The quantity of matrix spike used is given in Table 4. Leach blanks shall be prepared using the same quantity of organic-free water as the quantity of $0.01 \mathrm{~N} \mathrm{NaOH}$ added to the sample. Stepwise instructions for performing the extractions are given in Sections 6.2, 7.2 and 8.2.

\section{SVOAs}

As shown in Figure 1, the solids portion of the as received sample is leached (with ultrasonic agitation) once with $50 \mathrm{~mL}$ of organic-free $0.01 \mathrm{~N} \mathrm{NaOH}$ solution. Based upon the earlier dissolution test using a 0.5-g aliquot, any solids remaining at a level greater than $1 \%$ of the original solids portion are separated and extracted separately. The $\mathrm{NaOH}$ leachate (i.e., dissolved solids) is extracted three times with equal portions of methylene chloride.

The $\mathrm{NaOH}$ leachate is then $\mathrm{pH}$ adjusted by slow drop-wise addition of phosphoric acid while the sample is cooled in an ice-bath during the acidification. If a solid precipitate is formed at a relative quantity of $>1 \%$ by volume, it is separated and extracted separately. The $\mathrm{pH}$-adjusted $\mathrm{NaOH}$ leachate is extracted three times with equal portions of methylene chloride.

The undissolved solids and any solids formed during the acidification process are combined, desiccated with sodium sulfate, and ultrasonic extracted three times using methylene chloride.

All SVOA extracts from the solids portion of the as received sample are combined and concentrated to $1 \mathrm{~mL}$ outside the hot cells. 


\section{Pesticide/PCBs}

As shown in Figure 2, the solids portion of the sample is leached (with ultrasonic agitation) twice with $40 \mathrm{~mL}$ of organic-free $0.01 \mathrm{~N} \mathrm{NaOH}$ solution. Based upon the earlier dissolution test using a $0.5-\mathrm{g}$ aliquot, any solids remaining at a level greater than $1 \%$ of the original solids portion are separated and extracted separately. The $\mathrm{NaOH}$ leachate (i.e., dissolved solids) is extracted three times with equal portions of methylene chloride.

The $\mathrm{NaOH}$ leachate is then $\mathrm{pH}$ adjusted by slow drop-wise addition of phosphoric acid while the sample is cooled in an ice-bath during the acidification. If a solid precipitate is formed at a relative quantity of $>1 \%$ by volume, it is separated and extracted separately. The $\mathrm{pH}$-adjusted $\mathrm{NaOH}$ leachate is extracted three times with equal portions of methylene chloride.

The undissolved solids and any solids formed during the acidification process are combined, desiccated with sodium sulfate, and ultrasonic extracted three times using a 1:1 methylene chloride/acetone solution.

All pesticide/PCB extracts from the solids portion of the as received sample are combined and concentrated to $1 \mathrm{~mL}$ outside the hot-cells.

\section{$\underline{\text { Dioxins/Furans }}$}

As shown in Figure 3, no liquids will be added to the solid portion of the solids sample, as was done for the SVOA and pesticide/PCB extractions. The dioxin extractions do not require a $\mathrm{pH}$ adjustment of the - wet centrifuged solids. A desiccant is mixed with the wet solids to retain any water, and the desiccated solids are ultrasonically extracted three times with a 1:1 methylene chloride/acetone solution. The dioxin extracts are combined and concentrated to $1 \mathrm{~mL}$ outside the hot-cells.

\subsection{Preparation and Extraction of Matrix Spikes and LCS for SVOA, Dioxins/Furans and pesticide/PCB analysis}

A separate LCS will be prepared for each analysis outside the hot-cells using the sample reagents used for the extraction of the HLW samples. The LCS matrix will consist of 1 Liter of distilled water. The LCSs will be extracted using liquid-liquid extraction. The LCSs will be spiked with the compounds and levels listed in Table 4. Separate LCSs will be prepared for SVOA, Dioxin/Furans, pesticides, and PCBs. The LCS will be spiked with the same surrogates as listed in Table 3.

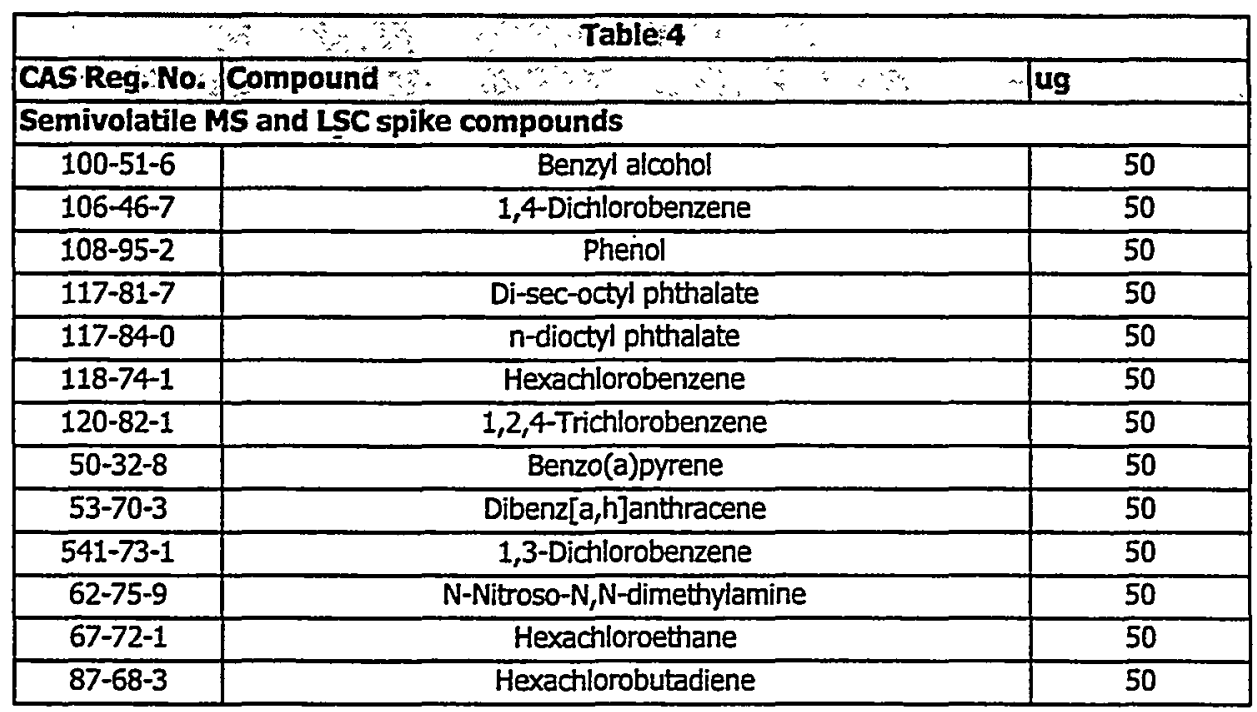




\begin{tabular}{|c|c|c|}
\hline \multicolumn{3}{|c|}{ Table 4} \\
\hline CAS Reg. No. & Compound & Jug \\
\hline $87-86-5$ & Pentachiorophenol & 50 \\
\hline $91-20-3$ & Naphthalene & 50 \\
\hline $95-50-1$ & 1,2-Dichlorobenzene & 50 \\
\hline $98-95-3$ & Nitrobenzene & 50 \\
\hline $100-00-5$ & p-Nitrochlorobenzene & 50 \\
\hline $100-25-4$ & 1,4-Dinitrobenzene & 50 \\
\hline $110-86-1$ & Pyridine & 50 \\
\hline $122-39-4$ & $\mathrm{~N}, \mathrm{~N}$-Diphenylamine & 50 \\
\hline $126-73-8$ & Tributyl phosphate & 50 \\
\hline $128-37-0$ & 2,6-Bis(tert-butyl)-4-methylphenol & 50 \\
\hline $1319-77-3$ & Cresol & 50 \\
\hline $2234-13-1$ & Octachloronaphthalene & 50 \\
\hline $82-68-8$ & Pentachloronitrobenzene (PCNB) & 50 \\
\hline $88-85-7$ & 2-sec-Butyl-4,6-dinitrophenol (Dinoseb) & 50 \\
\hline $92-52-4$ & 1,1'-Biphenyl & 50 \\
\hline $98-86-2$ & Acetophenone & 50 \\
\hline \multicolumn{3}{|c|}{ PCB MS and LCS spike compounds } \\
\hline $11097-69-1$ & PCB Arochlor 1254 & 0.5 \\
\hline \multicolumn{3}{|c|}{ Pesticides MS and LCS spike compounds } \\
\hline $58-89-9$ & Gamma-BHC & 0.2 \\
\hline $50-29-3$ & $4,4^{\prime}-\mathrm{DDT}$ & 0.8 \\
\hline $72-20-8$ & Endrin & 0.8 \\
\hline $76-44-8$ & Heptachlor & 0.2 \\
\hline $309-00-2$ & Aldrin & 0.2 \\
\hline $60-57-1$ & Dieldrin & 0.8 \\
\hline \multicolumn{3}{|c|}{ Dioxins/Furans MS and LCS spike compounds } \\
\hline $1746-01-6$ & $2,3,7,8$-Tetrachlorodibenzo-p-dioxin (TCDD) & 8.0 \\
\hline $40321-76-4$ & 1,2,3,7,8-Pentachlorodibenzo-p-dioxin (PeCDD) & 40 \\
\hline $57653-85-7$ & $1,2,3,6,7,8$-Hexachlorodibenzo-p-dioxin ( $H \times C D D)$ & $\overline{40}$ \\
\hline $35822-39-4$ & $1,2,3,4,6,7,8$-Heptachlorodibenzo-p-dioxin (HpCDD) & 40 \\
\hline $3268-87-9$ & $1,2,3,4,6,7,8,9$-Octachlorodibenzo-p-dioxin (OCDD) & 80 \\
\hline $51207-31-9$ & 2,3,7,8-Tetrachlorodibenzofuran (TCDF) & 8.0 \\
\hline $57117-41-6$ & $1,2,3,7,8$-Pentachlorodibenzofuran (PeCDF) & 40 \\
\hline $57117-44-9$ & $1,2,3,6,7,8$-Hexachlorodibenzofuran (HXCDF) & 40 \\
\hline $67562-39-4$ & $1,2,3,4,6,7,8$-Heptachlorodibenzofuran (HpCDF) & 40 \\
\hline $39001-02-0$ & $1,2,3,4,6,7,8,9$-Octachlorodibenzofuran (OCDF) & 80 \\
\hline
\end{tabular}

\subsection{Preparation of Organic Anion Samples}

The organic anion sample preparation uses a sodium-form of a cation exchange column to remove most of the radioactive cesium and strontium to reduce the overall radioactivity in the samples. Organic anion samples (1-mL supernatant samples and $1 \mathrm{~g}$ wet solids samples) are prepared in accordance with procedure AOAM-03. For further guidance and questions regarding execution of this procedure contact James A. Campbell, 376-0899.

\subsection{Initial Testing}

\subsection{Determination of Titration Curves for Supernatants and Soluble Fraction of Wet Centrifuged Solids}


1) Transfer a $0.5-\mathrm{mL}$ aliquot of the supernatant (or soluble solids fraction) into a tared 100 - $\mathrm{mL}$ beaker and weigh.

2) Add $10 \mathrm{~mL}$ of $0.01 \mathrm{~N}$ sodium hydroxide solution (prepared from organic-free water) and a clean magnetic stir bar to the beaker containing the aliquot. Measure and record the initial $\mathrm{pH}$.

3) Titrate the sample to $\mathrm{pH} 2$ using $0.1 \mathrm{~N} \mathrm{H}_{3} \mathrm{PO}_{4}$ solution. Record the acid volume, temperature and $\mathrm{pH}$ at $\Delta 0.1-0.2 \mathrm{pH}$ units. Note the acid volume and $\mathrm{pH}$ at the point where any precipitation begins to occur, or redissolve. Repeat this titration using $0.1 \mathrm{~N} \mathrm{HNO}_{3}$ solution.

4) Using the titration spreadsheet, plot the curves for both the supernatant and soluble solids fraction.

5) Closely examine the curves. Find a region of the curve where the $\mathrm{pH}$ is near 6.5 and exhibits some buffering behavior. Calculate the quantity of acid needed per gram of sample to adjust the $\mathrm{pH}$ to the midpoint of this region. Review the data with the cognizant scientist prior to adjusting the $\mathrm{pH}$ of the extraction sample.

\subsection{Determination of Insoluble Solids Content}

1) Transfer a 0.5-g aliquot of the centrifuged solids into a tared centrifuge tube and weigh.

2) Add $10 \mathrm{~mL}$ of $0.01 \mathrm{~N} \mathrm{NaOH}$ solution in $1-\mathrm{mL}$ aliquots. After each addition, swirl the centrifuge tube for a few minutes and observe and record any dissolution of the solid that appears to occur after each addition. If all of the solids dissolve before $10 \mathrm{~mL}$ of $0.01 \mathrm{~N} \mathrm{NaOH}$ solution have been added, record this volume for use in Step 1, Sections 6 and 7.

3) Centrifuge the tube at the highest safe speed for the centrifuge tube for approximately 15 minutes. Carefully decant the liquid portion and reweigh the centrifuge tube containing the residual centrifuged solids.

4) Calculate the percentage of solids remaining.

5) If the solids remaining are less than one percent of the original wet solids, $0.01 \mathrm{~N} \mathrm{NaOH}$ solution water should be added to the solids and then extracted as a liquid sample. If the solids remaining are greater than $1 \%$ then the dissolved portion will be extracted as a liquid and the insoluble solids will be extracted using ultrasonication extraction.

\subsection{Stepwise Instructions for Preparation of Semi-volatile Organic Samples}

Note: Prior to performing SVOA extractions, perform activities defined in Sections 1.0 and 1.1 and Section 5.0. Figure 1 provides a schematic of the following steps.

\subsection{Solids}

1) Transfer 5-g aliquot (2.5-g aliquot for MS and MSD) of the centrifuged solids to a tared 200-mL centrifuge tube and weigh.

2) Add the surrogate spiking solution to all samples (including blank) and the target compound spiking solution to the MS and MSD. Use the entire contents of the vial(s) provided for spiking. After transferring the contents of the spiking vial to the sample, add approximately $0.2 \mathrm{~mL}$ of methylene chloride to the vial(s) and transfer this rinsate to the sample. 
3) Add $50 \mathrm{~mL}$ of organic-free $0.01 \mathrm{~N} \mathrm{NaOH}$ solution to the centrifuge tube and ultrasonicate (pulsed) for 2 minutes.

4) Centrifuge the tube and decant the liquid into a tared bottle, labeled SVOA C-104 SF1, and weigh. Set aside the wet solids for ultrasonic extraction (Step 7).

5) Transfer the $\mathrm{NaOH}$ leachate sample to a centrifuge tube and while stirring vigorously, very slowly adjust the $\mathrm{pH}$ of the soluble solids to near 6.5 and verify final $\mathrm{pH}$. This step should be done using an ice bath to cool the sample.

Note: The quantity of acid required for adjusting the $\mathrm{pH}$ to near 6.5 is determined by titrating an aliquot of the $\mathrm{NaOH}$ leachate (i.e., soluble solids fraction) per Section 5.1.

Note: If solids are formed that do not redissolve, centrifuge and decant the liquid into a separatory funnel. Cap the centrifuge tube containing the wet solids and set aside for ultrasonic extraction (Step 7).

6) Transfer leachate to a separatory funnel and perform a set of three sequential separatory funnel shakeout extractions of the $\mathrm{pH}$-adjusted liquid using $25-\mathrm{mL}$ portions of methylene chloride. Collect and combine the three extracts in the $250-\mathrm{mL}$ amber bottle labeled as designated below.

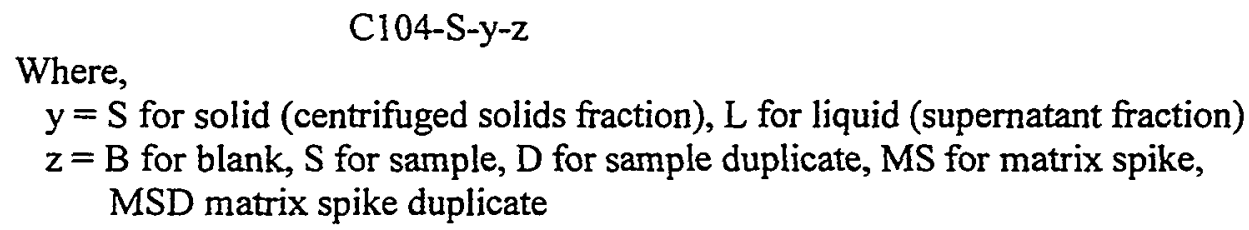

7) Combine the solids reserved in Step 4 and any solids formed in Step 5 and add 2-3 times amount of anhydrous sodium sulfate desiccant and stir with a glass or metal rod until a sandy texture is obtained.

8) Add $25 \mathrm{~mL}$ of methylene chloride and ultrasonicate (pulsed) for 2 minutes. Settle (or centrifige if necessary) and decant the extract into the $250-\mathrm{mL}$ amber bottle labeled in Step 6.

9) Repeat Step 8 two additional times and combine the extracts.

\subsection{Superatant}

1) Transfer $20-\mathrm{mL}$ aliquot (10-mL aliquot for MS and MSD) of the C-104 supernatant into a separatory funnel and dilute with $25 \mathrm{~mL}$ of $0.01 \mathrm{~N} \mathrm{NaOH}$.

2) Add the surrogate spiking solution to all samples (including blank) and the target compound spiking solution to the MS and MSD. Use the entire contents of the vial(s) provided for spiking. After transferring the contents of the spiking vial to the sample, add approximately $0.2 \mathrm{~mL}$ of methylene chloride to the vial(s) and transfer this rinsate to the sample.

3) Perform three sequential separatory funnel shakeout extractions of the supernatant using $25-\mathrm{mL}$ portions of methylene chloride. Collect and combine the three extracts in a $250-\mathrm{mL}$ amber bottle labeled as designated in Section 6.1 Step 6.

4) Transfer the sample to a centrifuge tube and while stirring vigorously, very slowly adjust the pH of the sample with the quantity of acid calculated in Section 5.1 for supernatant sample and verify final $\mathrm{pH}$. This step should be done using an ice bath to cool the sample. 
Note: If solids are formed that do not redissolve, centrifuge and decant the liquid back into the separatory funnel used in Step 1. Cap the centrifuge tube containing the wet solids and set aside for ultra-sonic extraction.

5) Transfer supernatant to the separatory funnel used in Step 1 and perform a second set of three sequential separatory funnel shakeout extractions of the $\mathrm{pH}$-adjusted liquid using $25-\mathrm{mL}$ portions of methylene chloride. Collect and combine the three extracts in the $250-\mathrm{mL}$ amber bottle labeled in Step 3.

6) To any solids formed in Step 4, add 2-3 times amount of anhydrous sodium sulfate desiccant and stir with a glass or metal rod until a sandy texture is obtained.

7) Add $25 \mathrm{ml}$ of methylene chloride and ultrasonicate (pulsed) for 2 minutes. Settle (or centrifuge if necessary) and decant the extract into the $250-\mathrm{mL}$ amber bottle labeled in Step 3.

8) Repeat Step 7 two additional times and combine the extracts.

For further guidance and questions regarding execution of these steps, and those described in Appendix A, for extraction of SVOA samples contact George S. Klinger, 372-0448.

\subsection{Stepwise Instructions for Preparation of Pesticide/PCB Organic Samples}

Note: Prior to performing pesticide/PCB extractions, perform activities defined in Sections 1.0 and 1.1 and Section 5.0. Figure 2 provides a schematic of the following steps.

\subsection{Solids}

1) Transfer 5-g aliquot (2.5-g aliquot for MS and MSD) of the centrifuged solids to a tared 200-mL centrifuge tube and weigh.

2) Add the surrogate spiking solution to all samples (including blank) and the target compound spiking solution to the MS and MSD. Use the entire contents of the vial(s) provided for spiking. After transferring the contents of the spiking vial to the sample, add approximately $0.2 \mathrm{~mL}$ of methylene chloride to the vial(s) and transfer this rinsate to the sample.

3) Add $40 \mathrm{~mL}$ of organic-free $0.01 \mathrm{~N} \mathrm{NaOH}$ solution to the centrifuge tube and ultrasonicate (pulsed) for 2 minutes.

4) Centrifuge the tube and decant the liquid into a tared bottle, labeled PPCB C-104 SF1.

5) Repeats Steps 3 and 4 and.weigh bottle PPCB C-104 SF1. Set aside the wet solids for ultrasonic extraction (Step 8).

6) Transfer the $\mathrm{NaOH}$ leachate sample to a centrifuge tube and while stirring vigorously, very slowly adjust the $\mathrm{pH}$ of the soluble solids to near 6.5 and verify final $\mathrm{pH}$. This step should be done using an ice bath to cool the sample.

Note: The quantity of acid required for adjusting the $\mathrm{pH}$ to near 6.5 is determined by titrating an aliquot of the $\mathrm{NaOH}$ leachate (i.e., soluble solids fraction) per Section 5.1. 
Note: If solids are formed that do not redissolve, centrifuge and decant the liquid into a separatory funnel. Cap the centrifuge tube containing the wet solids and set aside for ultrasonic extraction (Step 8).

7) Transfer leachate to a separatory funnel and perform a set of three sequential separatory funnel shakeout extractions of the $\mathrm{pH}$-adjusted liquid using $25-\mathrm{mL}$ portions of methylene chloride. Collect and combine the three extracts in the $250-\mathrm{mL}$ amber bottle labeled as designated below.

Where,

$$
\text { C104-P-y-z }
$$

$y=S$ for solid (centrifuged solids fraction), $L$ for liquid (supernatant fraction)

$\mathrm{z}=\mathrm{B}$ for blank, $\mathrm{S}$ for sample, $\mathrm{D}$ for sample duplicate, MS for PCB matrix spike, MSD for PCB matrix spike duplicate, MSP for pesticide spike, MSDP for pesticide matrix spike duplicate

8) Combine the solids reserved in Step 5 and any solids formed in Step 6 and add 2-3 times amount of anhydrous sodium sulfate desiccant and stir with a glass or metal rod until a sandy texture is obtained.

9) Add $25 \mathrm{ml}$ of methylene chloride/acetone mixture (1:1) and ultrasonicate (pulsed) for 2 minutes. Settle (or centrifuge if necessary) and decant the extract into the $250-\mathrm{mL}$ amber bottle labeled in Step 7.

10) Repeat Step 9 two additional times and combine the extracts.

\subsection{Superatant}

1) Transfer $10-\mathrm{mL}$ aliquot of the C-104 supernatant into a separatory funnel and dilute with $25 \mathrm{~mL}$ of $0.01 \mathrm{~N} \mathrm{NaOH}$.

2) Add the surrogate spiking solution to all samples (including blank) and the target compound spiking solution to the MS and MSD. Use the entire contents of the vial(s) provided for spiking. After transferring the contents of the spiking vial to the sample, add approximately $0.2 \mathrm{~mL}$ of methylene chloride to the vial(s) and transfer this rinsate to the sample.

3) Perform three sequential separatory funnel shakeout extractions of the supernatant using 25-mL portions of methylene chloride. Collect and combine the three extracts in a $250-\mathrm{mL}$ amber bottle labeled as designated in Section 7.1 Step 7.

4) Transfer the sample to a centrifuge tube and while stirring vigorously, very slowly adjust the pH of the sample with the quantity of acid calculated in Section 5.1 for supernatant sample and verify final $\mathrm{pH}$. This step should be done using an ice bath to cool the sample.

Note: If solids are formed that do not redissolve, centrifuge and decant the liquid back into the separatory funnel used in Step 1. Cap the centrifuge tube containing the wet solids and set aside for ultra-sonic extraction.

5) Transfer supernatant to the separatory funnel used in Step 1 and perform a second set of three . sequential separatory funnel shakeout extractions of the liquid using $25-\mathrm{mL}$ portions of methylene chloride. Collect and combine the three extracts in the $250-\mathrm{mL}$ amber bottle labeled in Step 3.

6) To any solids formed in Step 4. Add 2-3 times amount of anhydrous sodium sulfate desiccant and stir with a glass or metal rod until a sandy texture is obtained. 
7) Add $25 \mathrm{ml}$ of methylene chloride/acetone mixture (1:1) and ultrasonicate (pulsed) for 2 minutes. Settle (or centrifuge if necessary) and decant the extract into the $250-\mathrm{mL}$ amber bottle labeled in Step 3.

8) Repeat Step 7 two additional times and combine the extracts.

For further guidance and questions regarding execution of these steps for pesticide/PCB extractions, contact Eric W. Hoppe, 376-2126.

\title{
8.0 Stepwise Instructions for Preparation of Dioxin/Furan Samples
}

Note: Prior to performing Dioxin/Furan extractions, perform activities defined in Sections 1.0 and 1.1 and Section 5.0. Figure 3 provides a schematic of the following steps.

1) Transfer 5-g aliquots (5-g aliquot for MS and MSD) of the centrifuged solids to a tared 200-mL centrifuge tube and weigh. Add the labeled spiking solution (i.e., surrogates) to all samples (including blank) and the unlabeled spiking solution (i.e., spikes) to the MS and MSD. Use the entire contents of the vial(s) provided for spiking. After transferring the contents of the spiking vial to the sample, add approximately $0.2 \mathrm{~mL}$ of methylene chloride to the vial(s) and transfer this rinsate to the sample.

2) Add 2-3 times the amount of anhydrous sodium sulfate desiccant. Stir with glass or metal rod until it forms a sandy texture. Add $25 \mathrm{~mL}$ of methylene chloride/acetone mixture (1:1) and ultrasonicate (pulsed) for 2 minutes. Settle (or centrifuge, if necessary) and decant the extract into $250-\mathrm{mL}$ amber bottle labeled as indicated below. Repeat methylene chloride/acetone extraction two more times and combine extracts.

\author{
Where, \\ C104-D-y-z \\ $\mathrm{y}=\mathrm{S}$ for solid (centrifuged solids fraction), $\mathrm{L}$ for liquid (supernatant fraction) \\ $z=B$ for blank, $S$ for sample, $D$ for sample duplicate, $M S$ for matrix spike, \\ MSD for matrix spike duplicate.
}

3) Transfer $15 \mathrm{~mL}$ of the $\mathrm{C}-104$ supernatant (7.5 mL for MS and MSD) into a separatory funnel and add $25 \mathrm{~mL}$ of $0.01 \mathrm{~N} \mathrm{NaOH}$ to the separatory funnel. Add the labeled spiking solution (i.e., surrogates) to all samples (including blank) and the unlabeled spiking solution (i.e., spikes) to the MS and MSD. Use the entire contents of the vial(s) provided for spiking. After transferring the contents of the spiking vial to the sample, add approximately $0.2 \mathrm{~mL}$ of methylene chloride to the vial(s) and transfer this rinsate to the sample.

4) Perform three sequential separatory funnel shakeout extractions of the supernatant using three $25-\mathrm{mL}$ portions of methylene chloride. Collect and combine the three extracts in a $250-\mathrm{mL}$ amber bottle labeled in Step 2.

For further guidance and questions regarding execution of these steps contact James A. Campbell, 376-0899. 


\section{Figure 1: SVOA Extraction Process Diagram}

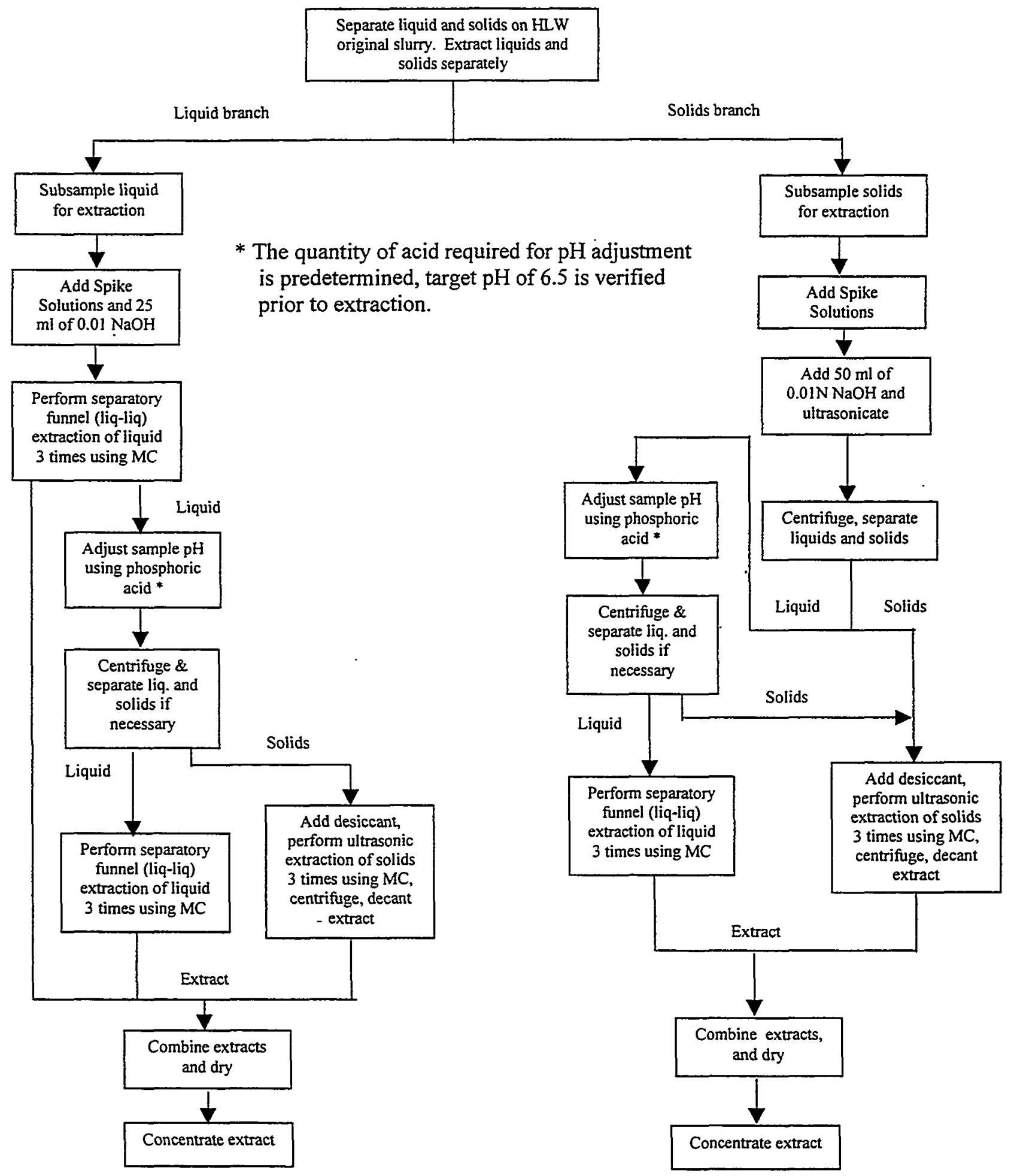




\section{Figure 2: Pesticide/PCB Extraction Process Diagram}

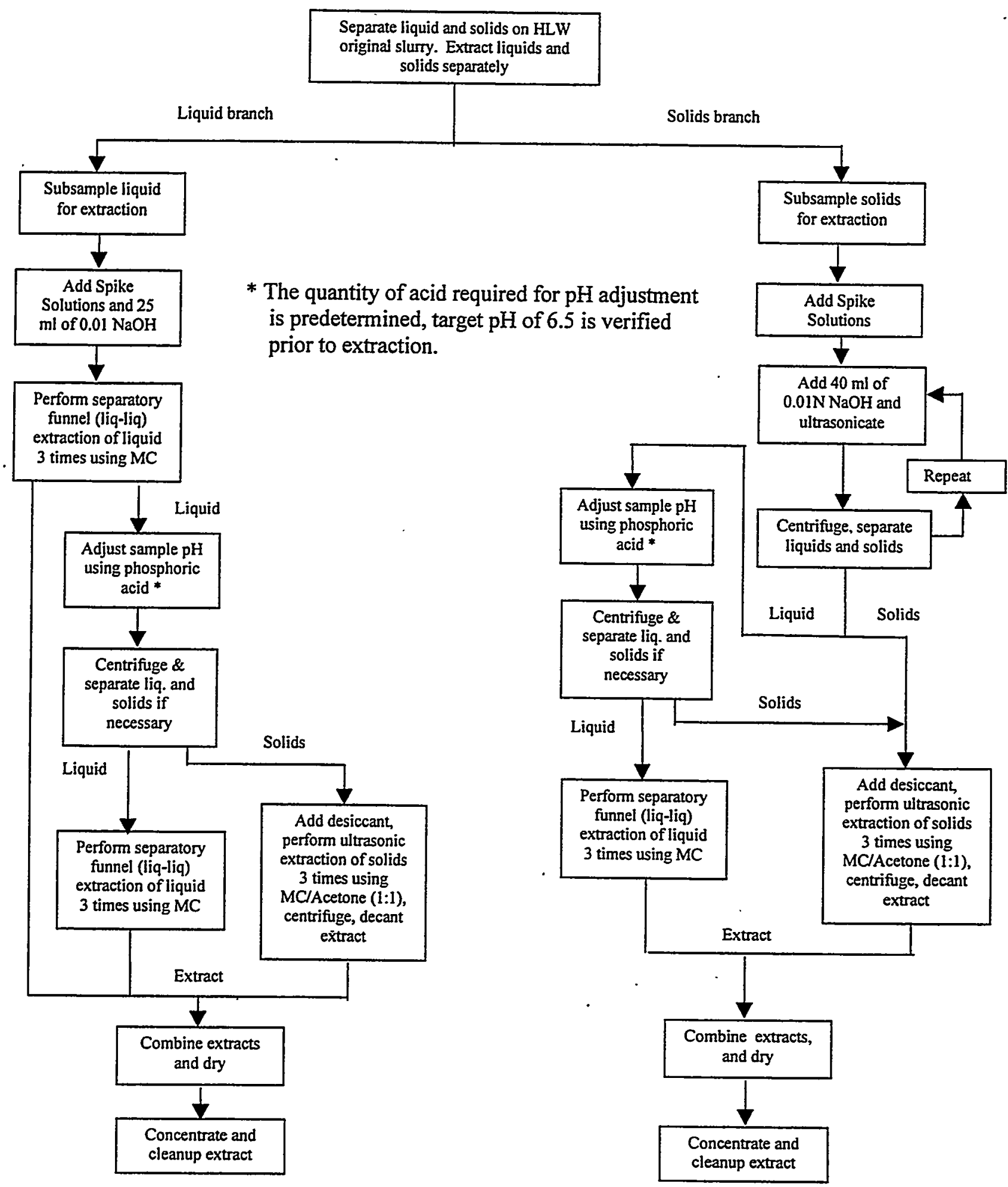




\section{Figure 3: Dioxin/Furan Extraction Process Diagram}

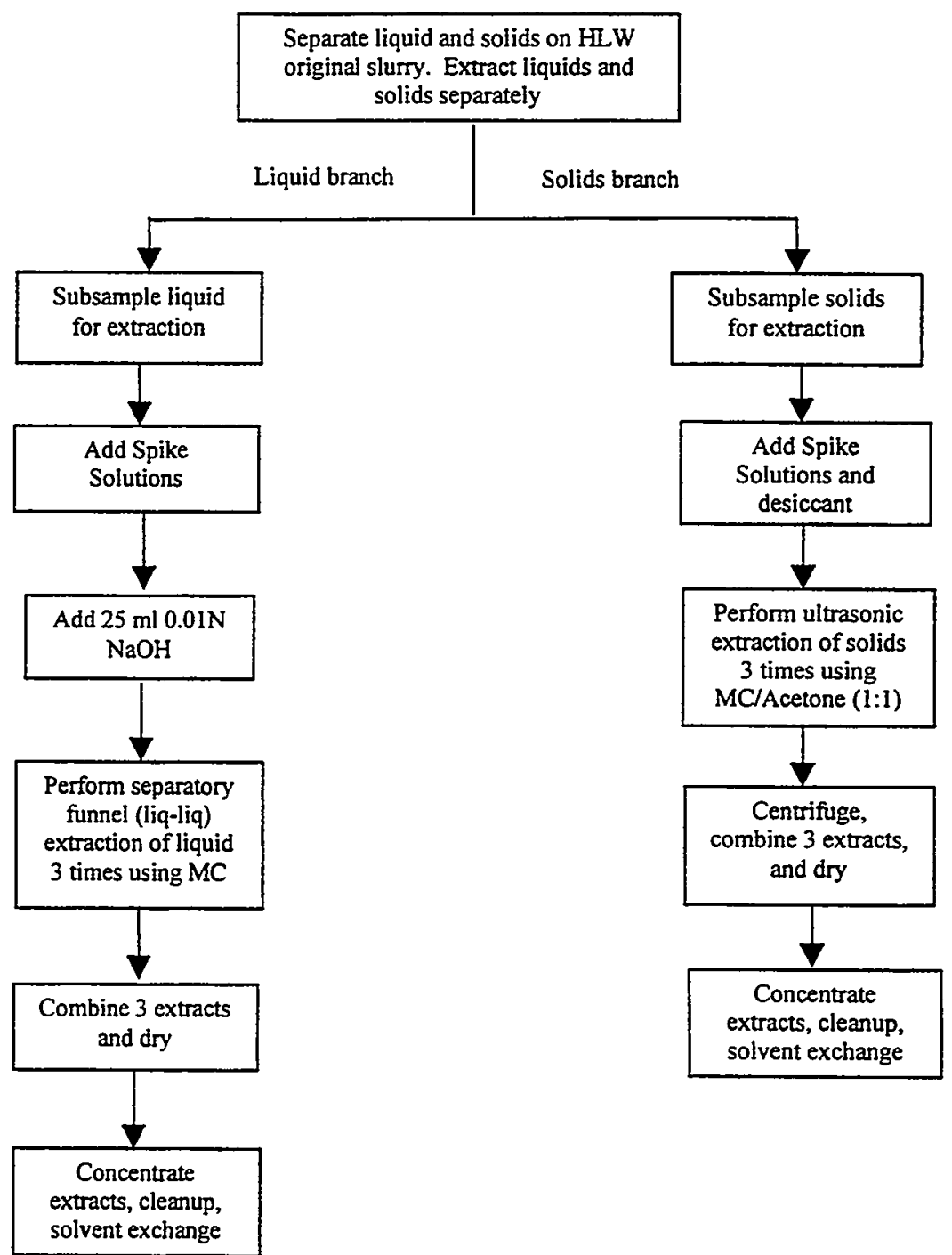


Prior work done on $\mathrm{AW}-101$ and $\mathrm{AN}-107$ samples using phosphoric acid to adjust the $\mathrm{pH}$ was complicated by large quantities of formed solids. It is assumed that some of the formed solids were the results of aluminum precipitation at $\mathrm{pH}$ less than 11 and greater than 3 . It is also likely that some of the formed solids were insoluble phosphates, which were formed upon addition of the phosphoric acid.

The use of nitric acid to adjust the $\mathrm{pH}$ of the sample to $\mathrm{pH} 3$ may have certain advantages in reducing or eliminating "formed solids" in the supernatant and the soluble portion of the centrifuged solids.

Additionally, it is likely that phosphate acts in a similar fashion to sulfate in its ability to catalyze nitrate (which is present in the C-104 material at a concentration of approximately $30,000 \mathrm{ppm}$ ) to form the reactive nitronium ion $\left(\mathrm{NO}_{3}\right)$, which is a powerful nitrating agent for a variety of organics.

Nitric acid alone produces only a small quantity of "auto-catalyzed" nitronium ion. We believe that the use of nitric acid, rather than phosphoric acid, to adjust the $\mathrm{pH}$ of the sample may eliminate or reduce formed solids, thus reducing the number of extraction steps, and also reduce or eliminate the quantity of nitration "artifacts".

Reaction of organic amines, such as chelator fragments found in some tank samples, with nitrous acid (HONO) may also be reduced by the addition of nitric acid.

In order to test this idea for application to potential future work, one additional semivolatile sample (supernatant only) will be processed using the procedure described in Sections 5.1 and 6, using $0.1 \mathrm{~N}$ nitric acid, rather than phosphoric acid, for the titration of the sample and $\mathrm{pH}$ adjustment during the extraction.

The supernatant used for this test is to be decanted/pipetted from container "C104 COMP E". 


\section{Analytical Service Request (ASR)}

Requestor --- Complete all fields on this COVER PAGE, unless specified as optional or ASR is a revision

\begin{tabular}{|c|c|c|c|}
\hline \multirow{2}{*}{\multicolumn{2}{|c|}{$\begin{array}{l}\text { Requestor: } \\
\text { Signature } \\
\text { Print Name }\end{array}$}} & \multirow{3}{*}{$\begin{array}{l}\text { PNNL Project \#: } \\
\text { Charge Code: } \\
\text { Date Required: }\end{array}$} & 29274 \\
\hline & & & Misc i \\
\hline Phone $.376-4454$ & MSIN $\rho 7.22$ & & AREATI \\
\hline
\end{tabular}

\begin{tabular}{|c|c|c|c|}
\hline \multicolumn{4}{|c|}{ Matrix Type Information } \\
\hline $\begin{array}{l}\text { + Liquids: } \\
\text { - Solids: }\end{array}$ & $\begin{array}{l}\text { - Aqueous } \\
\text { Soil } \\
\text { - Glass } \\
\text { - Smear }\end{array}$ & $\begin{array}{l}\text { - Organic } \\
\text { - Sludge } \\
\text { — Filter } \\
\text { - Organic }\end{array}$ & $\begin{array}{l}\text { Multi-phase } \\
\text { — Sediment } \\
\text { Metal } \\
\text { - Other }\end{array}$ \\
\hline$\uparrow$ Other: & $\begin{array}{l}V_{\text {Solid/Liq }} \\
\text { Gas }\end{array}$ & $\begin{array}{l}\text { quid Mixture, Sl } \\
\text { Biologica }\end{array}$ & $\begin{array}{l}\text { urry } \\
\text { a Specimen }\end{array}$ \\
\hline \multicolumn{4}{|c|}{ If sample martices vary, specify on Request Page } \\
\hline \multicolumn{4}{|c|}{ Disposal Information } \\
\hline \multirow{2}{*}{\multicolumn{4}{|c|}{$\begin{array}{l}\text { Disposition of Virgin Samples: } \\
\text { Virgin samples are returned to requestor unless } \\
\text { archiving provisions are made with receiving group! } \\
\text { If archiving, provide: } \\
\text { Archiving Reference Doc \# }\end{array}$}} \\
\hline & & & \\
\hline $\begin{array}{l}\text { Disposi } \\
\text { Disf }\end{array}$ & on of Tregted & Samples: & \\
\hline
\end{tabular}

QA/Special Requirements

+ QA Plan:

SBMS

HASQARD (CAWSRP)

- Additional QA Requirements? No _ or Reference Doc \#

- Field COC? No

- Lab COC Required? No

- Hold Time: None

or Other, Specify
\& Date Sampled
Time Sampled

- Special Storage-Requirements:

None $\_$Refrigerate $\left(4^{\circ} \mathrm{C}\right)$

or Other, specify

- Data Quality Review Required? No X Yes

Waste Designation Information
4 Sample Information Check List Attached? Yes $\checkmark$ or Reference Doc \#
or Previous ASR \#
Does the Waste Designation Documentation
Indicate Presence of PCBs?
or Previous RPL ID \#
No $\square$ Yes

Additional or Special Instructions See Speinal ensterictecn(AfHreillen)

Send Report To M He/c $\quad$ Phone $376-4454$

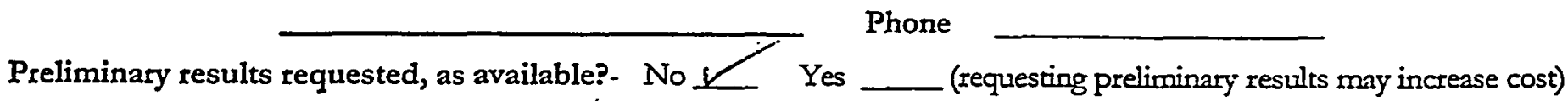

Reçeiving and Login Information (to be completed by laboratory staff)
Date Delivered:
Delivered By (optional) $2-14-200$
Time Delivered (optional)
ITLRE STAFF
Received By: S'PLL SIAFF
Group ID (optional)
CMC Waste Sample?

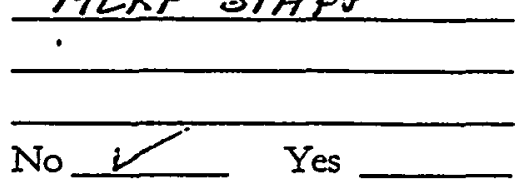
Cost Estimate, if requested:
$\$$
RPG/CMC Work Accepted By: ZM L U (AR/É Signature/Date:

ASR Number: $\frac{5729}{(00-1360)-(00.1360)}$

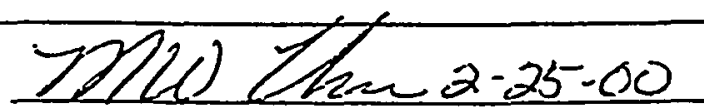


Analytical Service Request (ASR)

(REQUEST PAGE ----- Information Specific to Individual Samples)

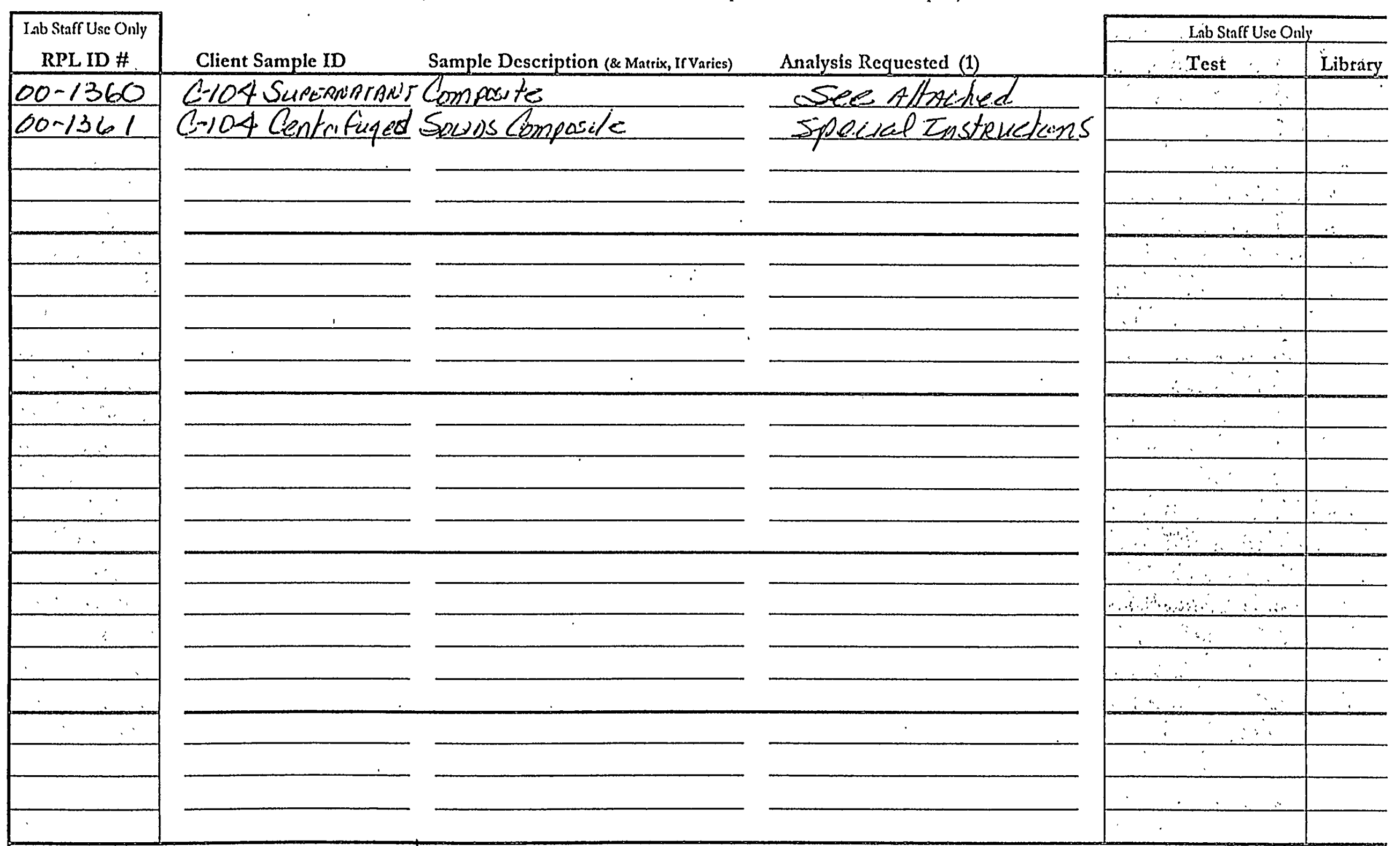

(1) See "Analysis Requested" Instructions: Provide analytes of interest and required detection levels.

[Information provided: Above ___ On Attachment __]

ASR \# 5729

Page

1 of

ASR FY2000 - RPG1.dhe 
00-01360 C-104 Supernatant Composite

$\begin{array}{lll}\text { Density/Solution } & \text { SAL } & \text {-- Use W49436 } \\ \text { Wt\% Solids/TDS } & \text { SAL } & \text { - Use W49436 } \\ \text { Digestion-128 } & \text { SAL } & \text { - Use W49436 } \\ \text { ICP-211-CMC } & \text { LAB } & \text { - Use CMC WP Number } \\ \text { ICP/MS } & \text { ADV INORG } & \text { - Use W49439 } \\ \text { GEA-381/474-CMC } & \text { RAD } & \text { - Use CMC WP Number } \\ \text { Alpha/Gross-4001/408-CMC } & \text { RAD } & \text { - Use CMC WP Number } \\ \text { Beta/Gross-4001/408-CMC } & \text { RAD } & \text { - Use CMC WP Number } \\ \text { Am,Cm/AEA-417/422-CMC } & \text { RAD } & \text { - Use CMC WP Number } \\ \text { Pu/AEA-417/422-CMC } & \text { RAD } & \text { - Use CMC WP Number } \\ \text { U/KPA-4014-CMC } & \text { RAD } & \text { - Use CMC WP Number } \\ \text { Sr-90-476/408-CMC } & \text { RAD } & \text { - Use CMC WP Number } \\ \text { Se79-440/474-CMC } & \text { RAD } & \text { - Use CMC WP Number } \\ \text { IC-212-CMC } & \text { LAB } & \text { - Use CMC WP Number } \\ \text { ICP/MS } & \text { ADV INORG } & \text { - Use W49439 } \\ \text { TOC/TIC-381-CMC } & \text { LAB } & \text { - Use CMC WP Number } \\ \text { TOC/TIC-380-CMC } & \text { LAB } & \text { - Use CMC WP Number } \\ \text { NH3-ISE } & \text { LAB } & \text { - Use W49439 } \\ \text { Flashpoint } & \text { LAB } & \text { - Use W49439 } \\ \text { CN/Total } & \text { LAB } & \text { - Use W49439 } \\ \text { H3-418/474-CMC } & \text { RAD } & \text { - Use CMC WP Number } \\ \text { C14-381/474-CMC } & \text { RAD } & \text { - Use CMC WP Number } \\ \text { Hg-131/201-CMC } & \text { LAB } & \text { - Use CMC WP Number } \\ \text { OH-/Titration-228-CMC } & \text { LAB } & \text { - Use CMS WP Number } \\ \text { pH/Solution } & \text { LAB } & \text { - Use W49439 } \\ & & \\ \text { Ext-S/SVOA } & \text { SAL } & \text { - Use W49436 } \\ \text { SVOA/GCMS } & \text { ORG } & \text { - Use W49440 } \\ \text { Ext-Solvent (for PCB) } & \text { SAL } & \text { - Use W49436 } \\ \text { PCB/Pesticides } & \text { ORG } & \text { - Use W49441 } \\ \text { Ext-Solvent (for Dioxins) } & \text { SAL } & \text { - Use W49436 } \\ \text { Dioxins/Furans } & \text { ORG } & \text { - Use W49441 (this test needs added to DB) } \\ \text { IC-Organic } & \text { ORG } & \text { - Use W49441 (this test needs added to DB) } \\ \text { Headspace } & \text { ORG } & \text { - Use W49441 (this test needs added to DB) } \\ \text { VOA/GCMS } & \text { ORG } & \text { - Use W49440 } \\ & & \end{array}$


00-01361 C-104 Centrifuged Solids Composite

Wt\% Solids/Total (after phase

Digestion-129 separation) ICP-211-CMC

Fusion-115

ICP-211-CMC

ICP/MS

GEA-381/474-CMC

Alpha/Gross-4001/408-CMC Beta/Gross-4001/408-CMC $\mathrm{Am}, \mathrm{Cm} / \mathrm{AEA}-417 / 422-\mathrm{CMC}$ Pu/AEA-417/422-CMC U/KPA-40I4-CMC Sr-90-476/408-CMC Sc79-440/474-CMC

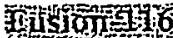

ICP/MS

Leach/Water-103

IC-212-CMC

NH3-ISE

H3-418/474-CMC

TOC/TIC-381-CMC

TOC/TIC-380-CMC

CN/Total

C14-381/474-CMC

Hg-131/201-CMC

Ext-S/SVOA SVOA/GCMS

Ext-Solvent (for PCB) $\mathrm{PCB} / \mathrm{pesticides}$

Ext-Solvent (for Dioxins)

Dioxins/Furans

IC-Organic

Headspace

VOA/GCMS
SAL - - Use W49436

SAL: -Use W49436

LAB - Use CMC WP Number

SAL':

LAB

ADVINORG

RAD

RAD

RAD

RAD

RAD

RAD̈

RAD

RAD

SAI:

ADY INORG

SAL

$L A B$

LAB

RAD

LAB

$L A B$

$L A B$

RÁD

LA:

SAI

ORG

SAT

ORG

SAL

ORG

ORG

ORG

ORG

-- Use W49436

- Use CMC WP Number

-- Use W49439

- Use CMC WP Number

- Use CMC WP Number

-- Use CMC WP Number

- Use CMC WP Number

-- Use CMC WP Number

-- Use CMC W'P Number

-- Use CMC WP Number

- Use CMC WP Number

- Use W49436

-- Use W49439

- Use W49436

-- Use CMC WP Number

-- Use W49439

- Use CMC WP Number

-- Use CMC WP Number

-- Use CMC WP Number

-- Use W49439

- Use CMC WP Number

- Use CMC WP Number

- Use W49436

- Use W49440

-- Use W49436

- Use W49441

-- Use W49436

-- Use W49441 (this test needs added to DB)

- Use W49441 (this test needs added to DB)

-- Use W49441 (this test needs added to DB)

- Use W49440 
Special Instructions (Revison 1) for ASR 5729

General Comment: This ASR is to complete the work defined by Test Plan BNFL-29953-30 Rev 0. Should sample quantities or other issues prohibit performing the work as defined, contact M.W. Urie (376-9454.)

The "C-104 Supernatant Composite" and "C-104 Centrifuged Solids Composite" are prepared from the $\mathrm{C}-104$ material supplied under COC BNFL-48 (i.e., C-104 Comp A, C-104 Comp B, and C-104 Sup A).

For both the supernatant and centrifuged solids sample, all organic analyses require Sample, Duplicate, Matrix Spike, and Matrix Spike Duplicate, and all inorganic and radiochemical analyses require Sample, Duplicate, Matrix Spike (except Wt\% solids, $\mathrm{OH}$, Flashpoint, density, and TDS which do not require a Matrix Spike). Only the ICP (acid digest only), SVOA, PCB/Pesticides, and Dioxin spiking solutions are to be added to Matrix Spikes during processing in the SAL. Process Blanks and Blank Spikes/LCSs are to be processed per the governing QA Plan.

Movement of sub-samples or processed samples from the SAL to the laboratories shall be done under Lab COC.

All supernatant results are to be reported on a per milliliter of supernatant basis and all centrifuged solids are to be reported on a per gram of wet centrifuged solids basis.

1. Prior to beginning the phase separation of the slurry material (C-104 Comp $A$ and C-104 Comp B), sub-sampling for TDS and Wt\% Solids (on centrifuged solids) is to be conducted and the tests performed per Test Instruction (TI) BNFL-29953-80 Rev 0.

2. The phase separation of the slurry material is to be conducted per instructions in TI BNFL-29953-80 Rev 0. All separated supernatant from C-104 Comp A and C-104 Comp B and supernatant from C-104 Sup A should be combined into single container.

3. All centrifuged solids sub-sampling activities that need to use undried solids should be conducted as soon as possible following phase separation. This includes VOA, Water ${ }^{-}$ Leach sub-samples, cyanide, mercury, C-14, and TOC/TIC.

4. Following the solids sub-sampling activities, all organic sub-sampling and preparative activities (solids or supernatant) should be completed, per TI BNFL-29953-80 Rev 0, as soon as possible and prior to any additional inorganic or radiochemical sub-sampling or procesșing.

5. Following the organic sub-sampling and processing/extraction activities, the remaining centrifuged solids should be dried to constant weight and mixed well prior to sub-sampling for further processing (e.g., for digestions, fusions). (If a large quantity of centrifuged solids remain following the organic activities, not all of the solids need to be dried.)

Page 3 of 3 


\section{APPENDIX B}




\section{Appendix B: Analytical Data}

B. 1 


\section{Battelle PNNL/RPL/Inorganic Analysis ... ICPAES Data Report}

Project:

Client:
29274 / W49436

M. Urie

REVISION 1

Client ID: "C-104 Supernatant Composite" \&

"C-104 Centrifuged Solids Composite"

ASR Number: 5729

Total Samples: 2

Procedure: $\quad$ PNL-ALO-211, "Determination of Elements by Inductively Coupled Argon Plasma Atomic Emission Spectrometry" (ICP-AES).

Analyst: $\quad \cdot$ JJ Wagner

Analysis Date (Filename): $\quad$ 04-20-00 (A0597 K/Ni), 04-26-00 (A0599 ALO-128/-129)

See Chemical Measurement Center 98620: ICP-325-405-1 File for Calibration and Maintenance Records.

M\&TE Number:

$$
\begin{aligned}
& \text { ICPAES instrument } \quad \text { - WB73520 } \\
& \text { Mettler AT400 Balance -- Ser.No. 360-06-01-029 }
\end{aligned}
$$

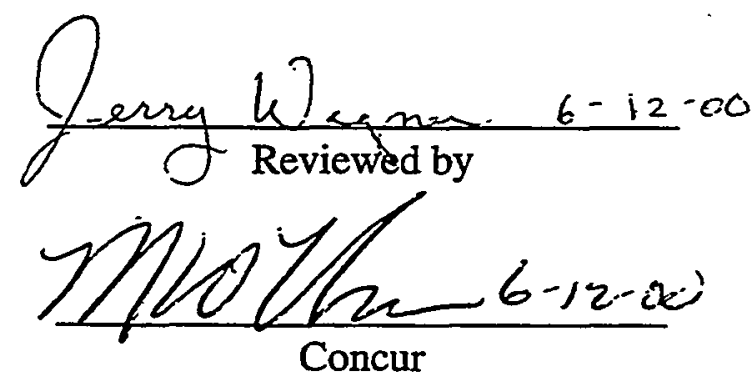




\section{Battelle PNNL/RPL/Inorganic Analysis ... ICPAES Data Report}

\section{ASR-5729}

One radioactive liquid sample, C-104 Supernatant Composite (RPL\# 00-01360), was prepared in duplicate by the Shielded Analytical Laboratory (SAL) using ALO-128 acid digestion of liquids procedure. Approximately $5.0 \mathrm{ml}$ of sample (weighed) was processed and diluted to a final volume of $25 \mathrm{ml}$. Sample aliquot volumes were calculated using the weight of sample processed divided by a density of approximately $1.166 \mathrm{~g} / \mathrm{ml}$. Estimated density was based upon the average verified delivery volume of a $5 \mathrm{ml}$ pipette used to transfer each sample aliquot during sample preparation and sample weight. Final volume of processed sample was calculated by measuring net weight of the final processed volume and dividing by density. Density of each prepared sample was estimated by weighing a one $\mathrm{ml}$ aliquot of each processed sample. After processing, sample aliquots were clear and did not require filtering. A process blank, blank-spike and matrix-spiked sample were also prepared. Calculated results of density measurements and volumes are recorded on bench sheets included in final ICPAES report data package. During ICPAES analysis additional simple dilution of 10 and 50-fold were performed in order to quantify high concentrations of certain analytes such as sodium. All measurement results reported have been corrected for analytical and sample dilutions. Results are reported as $\mu \mathrm{g} / \mathrm{ml}$.

One radioactive (dry) solid sample, C-104 Centrifuged Solids Composite (RPL\# 00-01361), was prepared in duplicate by SAL using ALO-129 acid leach of solids procedure and ALO-115 $\mathrm{KOH} / \mathrm{Ni}$ fusion procedure.

ALO-129 procedure: Approximately 0.5g aliquots were used to prepare samples using ALO-129 acid leach of solids procedure including a matrix-spiked sample. Final volume of processed sample was calculated by measuring net weight of the final processed volume and dividing by density. Density of each prepared sample was estimated by weighing a one ml aliquot of each processed sample. Some sample residue remained after processing. Residue was removed by filtering each sample aliquot. The process blank for the acid leach of solids procedure is the same as that used for ALO-128 acid digestion of liquids above. Calculated results of density measurements and volumes are recorded on bench sheets included in final ICPAES report data package. During ICPAES analysis additional simple dilution of 10 and 50 -fold were performed in order to quantify high concentrations of certain analytes such as sodium. All measurement results reported have been corrected for analytical and sample dilutions. Results are reported as $\mu \mathrm{g} / \mathrm{g}$-dry.

ALO-115 procedure: Approximately $0.2 \mathrm{~g}$ and $0.25 \mathrm{~g}$ size sample aliquots of dried centrifuged solids were prepared. Final volume of processed sample was $100 \mathrm{ml}$, prepared using volumetric flasks. Essentially the entire sample dissolved. No evidence of residue was noted. Preparation required the use of additional $\mathrm{HCl}$ to dissolve the samples. All solutions remained soluble after final dilution. During ICPAES analysis additional simple dilution of 2 and 10 -fold were performed in order to quantify high concentrations of certain analytes such as sodium, aluminum, iron, thorium, uranium and zirconium. Potassium and nickel measurement results are not 


\section{Battelle PNNL/RPL/Inorganic Analysis ... ICPAES Data Report}

applicable for this procedure because of reagents and crucible material used during sample preparation. Measurement results reported have been corrected for preparation and analytical dilution. ICPAES measurement results are reported as $\mu \mathrm{g} / \mathrm{g}$-dry.

Quality control check-standard results met tolerance requirements for analytes of interest except as noted below. Following is a list of quality control measurement results relative to ICPAES analysis tolerance requirements.

Five fold serial dilution:

(Fusion of solid samples) Results were generally within tolerance limit of $\leq 10 \%$ after correcting for dilution except as follows. Sodium in RPL\# 00-1361-Ni was high by approximately $12 \%$. All other analytes diluted similarly in this sample was within tolerance. All other sample dilutions performed were within tolerance.

(Acid digest/leach prepared samples)

All results were within tolerance limit of $\leq 10 \%$ after correcting for dilution.

Duplicate RPD (Relative Percent Difference):

(Fusion of solid samples) All analytes of interest were recovered within tolerance limit of $\leq 20 \%$ relative percent difference (RPD) except silver and phosphorous. RPD for silver was $28 \%$ and $55 \%$ for phosphorous.

(Acid digest/leach prepared samples)

All analytes of interest were recovered within tolerance limit of $\leq 20 \%$ relative percent difference (RPD).

Post-Spiked Samples (Group A):

(Fusion of solid samples) All analytes of interest were recovered within tolerance of $75 \%$ to $125 \%$.

(Acid digest/leach prepared samples)

All analytes of interest were recovered within tolerance of $75 \%$ to $125 \%$.

Post-Spiked Samples (Group B):

(Fusion of solid samples) All analytes of interest were recovered within tolerance of $75 \%$ to $125 \%$. 


\section{Battelle PNNL/RPL/Inorganic Analysis ... ICPAES Data Report}

(Acid digest/leach prepared samples)

All analytes of interest were recovered within tolerance of $75 \%$ to $125 \%$.

Blank Spike:

(Fusion of solid samples) A blank spike is not require for fusion prepared samples.

(Acid digest/leach prepared samples)

All analytes of interest in the blank spike 00-01360-BS were recovered within tolerance limit of $80 \%$ to $120 \%$ except silver (21\%). Chloride from the hydrochloric acid used to prepare the sample using PNLALO-128 digestion procedure likely precipitated the silver causing low recovery.

Matrix Spiked Sample:

(Fusion of solid samples) A matrix spike is not require for fusion prepared samples.

(Acid digest/leach prepared samples)

All analytes of interest in the matrix spiked sample (RPL\# 00-01360MS and RPL\# 00-01361-MS) were recovered within tolerance limit of $75 \%$ to $125 \%$ except silver $(24 \%, 27 \%)$, barium (56\%), and arsenic $(50 \%)$. Chloride from the hydrochloric acid used to prepare the sample using PNL-ALO-128 digestion likely precipitated silver resulting in low recovery. Low barium recovery results may be caused by the presence of sulfate in the sample. The reason for low recovery results for arsenic is not known.

\section{Quality Control Check Standards:}

Concentration of all analytes of interest except palladium in the $\mathrm{KOH} / \mathrm{Ni}$ fusion prepared analytical runs were within tolerance limit of $\pm 10 \%$ accuracy in the standards: QC_MCVA, QC_MCVB, and QC_SSTMCV. Calibration Blank (ICP98.0) concentration was less than two times IDL. Palladium in QC_MCVB measured low by 20 to $27 \%$. A single element standard of palladium at $2 \mu \mathrm{g} / \mathrm{ml}$ was measured at the beginning and end of the analytical run recovered $( \pm 3 \%)$ well within a tolerance limit of $\pm 10 \%$ accuracy.

Concentration of all analytes of interest in the acid digest/leach prepared samples was within tolerance limit of $\pm 10 \%$ accuracy in the standards: QC_MCVA, QC_MCVB, and QC_SSTMCV except as follows. Magnesium was high by $11 \%$ in one of four measurements of 


\section{Battelle PNNL/RPL/Inorganic Analysis ... ICPAES Data Report}

QC_MCVA check standard. Palladium in QC_MCVB measured low by $20 \%$. However, a single element standard of palladium at $2 \mu \mathrm{g} / \mathrm{ml}$ measured $2.1 \mu \mathrm{g} / \mathrm{ml}$ well within a tolerance limit of $\pm 10 \%$ accuracy indicating that the overall calibration for palladium was within tolerance. Palladium was not detected in any of the samples measured.

High Calibration Standard Check:

Verification of the high-end calibration concentration for all analytes of interest was within tolerance of $\pm 5 \%$ accuracy.

Process Blank:

(Fusion of solid samples) All analytes of interest were within tolerance limit of $\leq \mathrm{EQL}$ or $<5 \%$ of sample concentration.

(Acid digest/leach prepared samples)

All analytes of interest were within tolerance limit of $\leq \mathrm{EQL}$ or $<5 \%$ of sample concentration except boron and silicon. Boron concentration was about $6 \%$ of the concentration measured in C-104 Supernatant Composite sample and about $100 \%$ of the boron concentration measured in C-104 Centrifuged Solids Composite sample. Silicon concentration in the process blank was about $10 \%$ to $21 \%$ of the concentration measured in C-104 Centrifuged Solids Composite.

Laboratory Control Standard (LCS):

(Fusion of solid samples) All analytes of interest at a concentration equal to or greater than $\mathrm{EQL}$ were recovered within tolerance limit of $75 \%$ to $125 \%$ in both fusion prepared LCS standards. SRM-2710 Montana Soil was used for the LCS in PNNL-ALO-115 fusion preparations.

(Acid digest/leach prepared samples)

LCS was not required or prepared for acid digest or acid leached samples.

Analytes other than those requested by the client are for information only. Please note bracketed values listed in the data report are within ten times instrument detection limit and have a potential uncertainty much greater than $15 \%$. 


\section{Battelle PNNL/RPL/Inorganic Analysis ... ICPAES Data Report}

Comments:

1) "Final Results" have been corrected for all laboratory dilution performed on the sample during processing and analysis unless specifically noted.

2) Detection limits (DL) shown are for acidified water. Detection limits for other matrices may be determined if requested.

3) Routine precision and bias is typically $\pm 15 \%$ or better for samples in dilute, acidified water (e.g. $2 \% \mathrm{v} / \mathrm{v} \mathrm{HNO}_{3}$ or less) at analyte concentrations greater than ten times detection limit up to the upper calibration level. This also presumes that the total dissolved solids concentration in the sample is less than $5000 \mu \mathrm{g} / \mathrm{mL}$ ( 0.5 per cent by weight).

4) Absolute precision, bias and detection limits may be determined on each sample if required by the client.

5) The maximum number of significant figures for all ICP measurements is 2. 


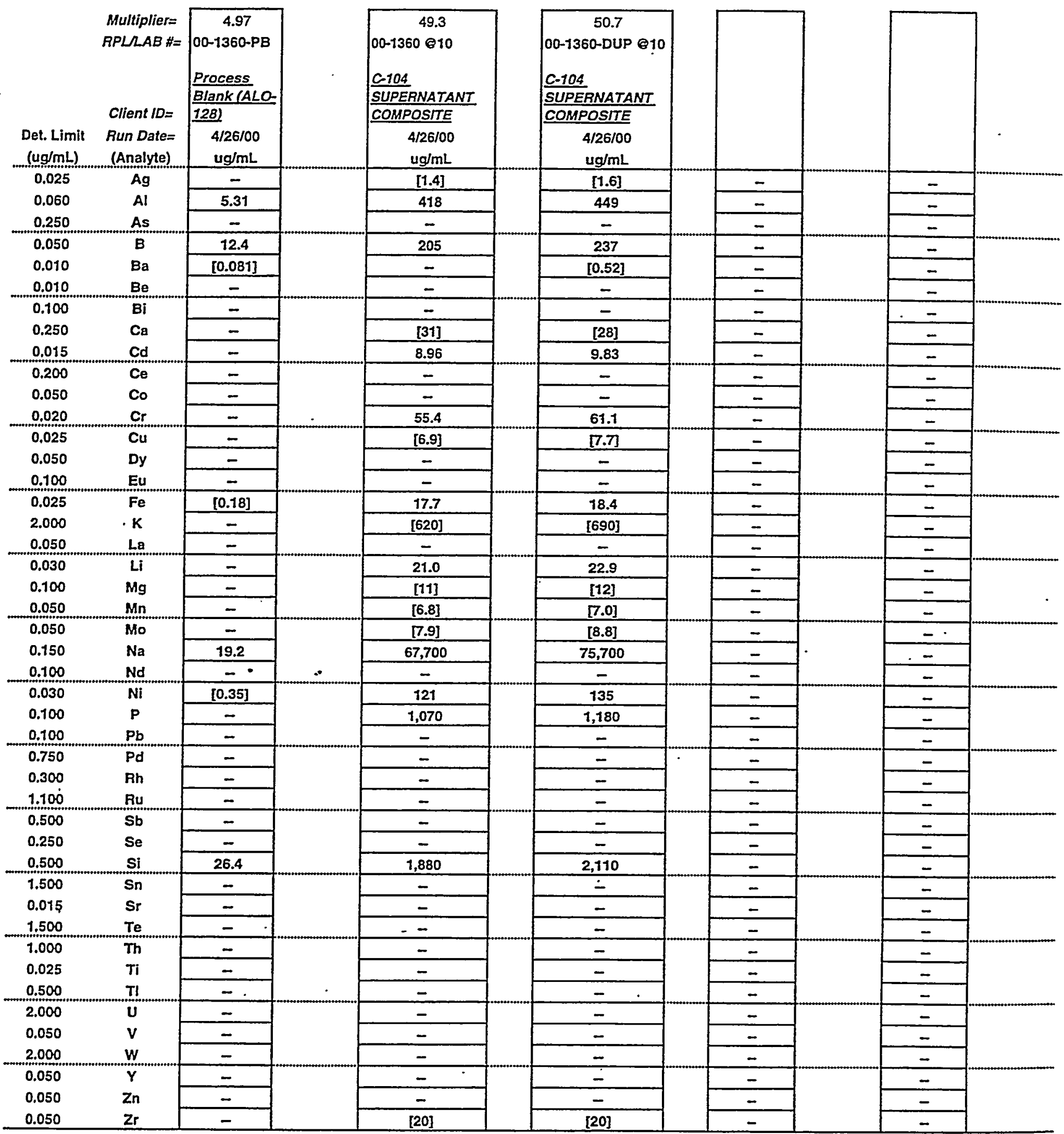

Note: 1) Overall error greater than 10-times detection limit is estimated to be within $+1-15 \%$.

2) Values in brackets [ are within 10-times detection limit with errors likely to exceed $15 \%$.

3) "--" indicate measurement is below detection. Sample detection limit may be found by

- multiplying "det. limit" (far left column) by "multiplier" (top of each column). 
Battelle PNNL/RPG/Inorganic Analysis ... ICPAES Data Report Page 1 of 1

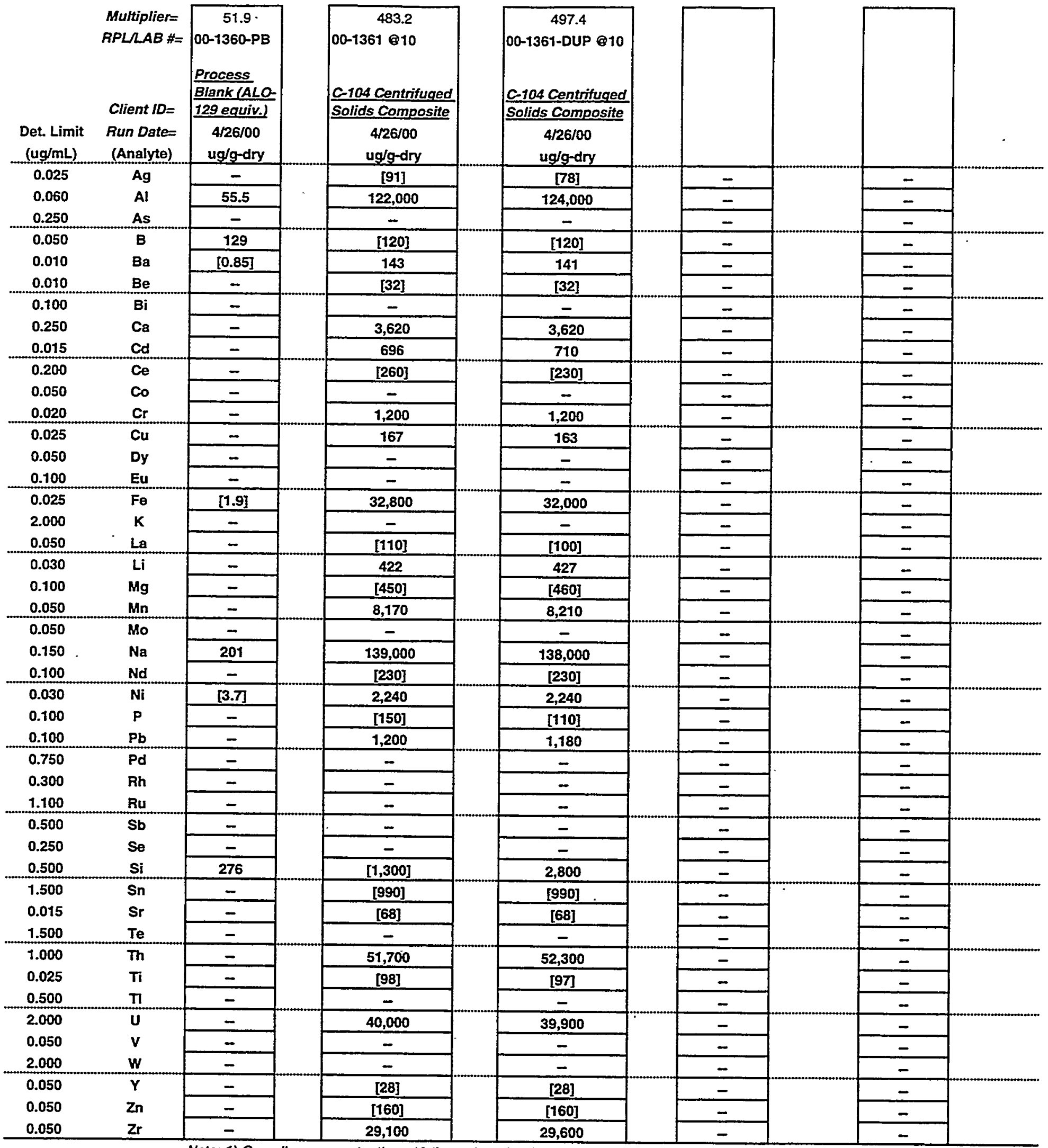

Note: 1) Overall error greater than 10-times detection limit is estimated to be within $+1-15 \%$.

2) Values in brackets $D$ are within 10-times detection limit with errors likely to exced $15 \%$.

3) "-" indicate measurement is below detection. Sample detection limit may be found by

multiplying "det. limit" (far left column) by "multiplier" (top of each column). 


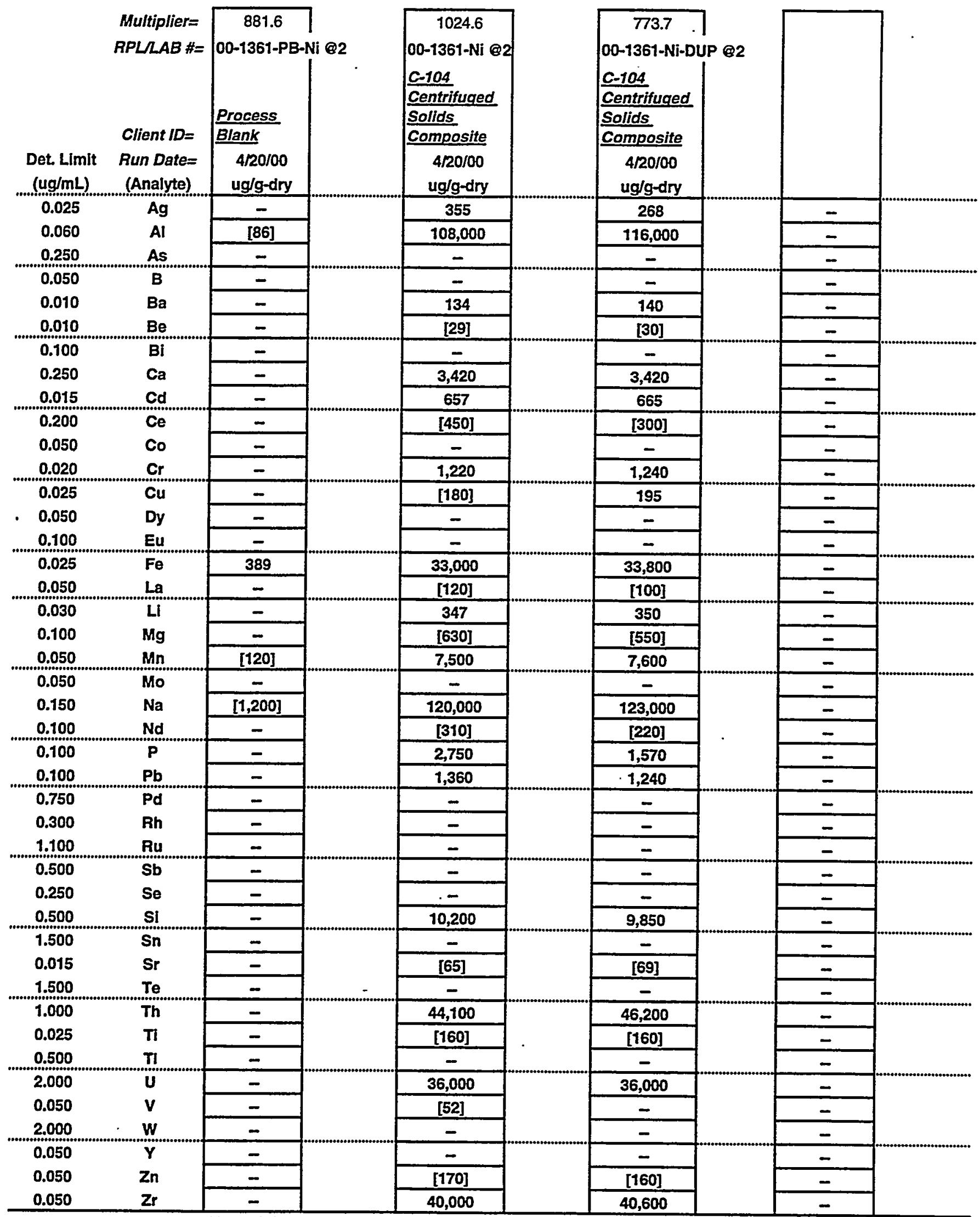

Note: 1) Overall error greater than 10-times detection limit is estimated to be within $+1-15 \%$.

2) Values in brackets $D$ are within 10-times detection limit with errors likely to exceed $15 \%$.

3) "- indicate measurement is below detection. Sample detection limit may be found by

multiplying "det. limit" (far left column) by "multiplier" (top of each column).

Data (1) from 'A0597 M.Urie ASR-5729 C-104, S.Fiskum ASR 5786 (1) CMC Waste ICP98 hi.XLS 
Battelle, Pacific Northwest National Laboratory

filename $00-1360 \mathrm{U}$

Richland, WA

$7 / 11 / 2000$

Radiochemical Processing Group

Rev. 1

Client: M. Urie

Cognizant Scientist: YRefeenred $>-11-00$

Concur: $\not . k$. fiokem 7/11/00

Procedure PNL-ALO-4014

Equipment: Chemcheck KPA11R

Uranium Analysis by Kinetic Phosphorescence

Sample

Uranium Concentration

Process Blank

00-1360PB

$\pm 1 \sigma \quad$ Units

C-104 Supernatant Comp.

$00-1360$

$<5 . \mathrm{E}-3$

$\mathrm{ug} / \mathrm{ml}$

C-104 Supernatant Comp.

00-1360 Rep

$2.86 \mathrm{E}+1 \quad \pm 3 \% \quad \mathrm{ug} / \mathrm{ml}$

C-104 Supernatant Comp.

00-1360 Dup

RPD

$2.85 \mathrm{E}+1 \pm 3 \% \quad \mathrm{ug} / \mathrm{ml}$

$3.00 E+1 \quad \pm 3 \% \quad \mathrm{ug} / \mathrm{ml}$

$5 \%$

Process Blank

00-1361 PB

9.13E-1

$\pm 2 \% \quad$ ug/g

C-104 Centrifuged Solids Comp.

$00-1361$

$3.35 \mathrm{E}+4 \quad \pm 3 \% \quad \mathrm{ug} / \mathrm{g}$

C-104 Centrifuged Solids Comp.

00-1361 Dup

$3.25 E+4 \quad \pm 3 \% \quad u g / g$

RPD

$3 \%$

Liquids blank

$<5$.E-3

Liquid matrix spike

- $101 \%$

Solids blank

$<4$.E-1

1

Solid matrix spike

$$
99 \% \text {. }
$$

\begin{tabular}{|c|c|c|c|c|}
\hline & Standard & Observed & Expected & Yield \\
\hline \multirow{5}{*}{\begin{tabular}{|l} 
Before \\
Run
\end{tabular}} & $R-330-f$ & $1.03 \mathrm{E}-4$ & $1.00 \mathrm{E}-4$ & 1.030 \\
\hline & $R-330-e$ & $1.04 \mathrm{E}-3$ & $1.00 E-3$ & 1.040 \\
\hline & $R-330-d$ & $9.97 \mathrm{E}-3$ & $1.00 \mathrm{E}-2$ & 0.997 \\
\hline & $R-330-c$ & $9.89 E-2$ & 1.00E-1 & 0.989 \\
\hline & $R-330-b$ & $9.61 \mathrm{E}-1$. & $1.00 \mathrm{E}+0$ & 0.961 \\
\hline After & R-330-e & $1.05 \mathrm{E}-3$ & $1.00 \mathrm{E}-3$ & 1.050 \\
\hline Run & R-330-c & $1.02 \mathrm{E}-1$ & $1.00 E-1$ & 1.020 \\
\hline
\end{tabular}

Page 1 of 1 
Battelle Pacific Northwest Laboratory

Radiochemical Processing Group-325 Building

Chemical Measurements Center

Client: M. Urie

Cognizant Scientist:

\section{Concur :}

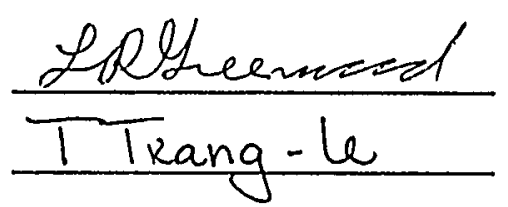

Measured Activities uCi/g with 1-s error

\section{ALO ID}

Client ID

00-1360PB *

Process Blank

$00-1360 *$

C-104 Supernatant Comp.

00-1360 DUP*

C-104 Supernatant Comp. RPD

00-1361 PB

Process Blank

$00-1361$

C-104 Centrifuged Solids Comp.

00-1361 Dup

C-104 Centrifuged Solids Comp.

RPD

Solids blank

Matrix spike

Blank spike

Note: "Data for sample 00-1360 are reported as $\mathrm{uCi} / \mathrm{ml}$
$00-1360$

$5 / 24 / 2000$

Rev. 2

Date: $5 / 24 / 00$

Date: $5 / 24100$

\begin{tabular}{|c|c|c|c|c|c|c|c|c|c|c|c|}
\hline $\begin{array}{c}\text { Beta } \\
\text { Error }+/- \\
\end{array}$ & $\begin{array}{c}\text { Sr-90 } \\
\text { Error +/- } \\
\end{array}$ & $\begin{array}{c}\text { Co-60 } \\
\text { Error }+1- \\
\end{array}$ & $\begin{array}{c}\mathrm{Nb}-94 \\
\text { Error +/- } \\
\end{array}$ & $\begin{array}{c}\text { Ru/Rh-106 } \\
\text { Error }+1-\end{array}$ & $\begin{array}{l}\text { Sb-125 } \\
\text { Error +/- } \\
\end{array}$ & $\begin{array}{c}\text { Sn/Sb-126 } \\
\text { Error + } /-\end{array}$ & $\begin{array}{l}\text { Cs-134 } \\
\text { Error +/- }\end{array}$ & $\begin{array}{c}\text { Cs-137 } \\
\text { Error +/- } \\
\end{array}$ & $\begin{array}{l}\text { Eu-154 } \\
\text { Error +/- }\end{array}$ & $\begin{array}{c}\text { Eu-155 } \\
\text { Error +/- } \\
\end{array}$ & $\begin{array}{l}\text { Am-241 } \\
\text { Error +1- }\end{array}$ \\
\hline $\begin{array}{c}1.42 E-3 \\
9 \%\end{array}$ & $<2 . E-3$ & $<4 . E-6$ & $<3 . E-6$ & $<3 . E-5$ & $<9 . E-6$ & $<3 . E^{\prime}-6$ & $<4 . E-6$ & $\begin{array}{c}1.27 \mathrm{E}-4 \\
5 \%\end{array}$ & $<9 . E-6$ & $<2 . E-5$ & $<3 . E-5$ \\
\hline $\begin{array}{c}3.00 E+1 \\
4 \%\end{array}$ & $\begin{array}{c}1.06 E-1 \\
16 \%\end{array}$ & $\begin{array}{c}4.22 \mathrm{E}-2 \\
3 \%\end{array}$ & $<2 . E-3$ & $<9 . E-2$ & $<6 . E-2$ & $<2 . E-2$ & $<2 . E-3$ & $\begin{array}{c}3.66 E+1 \\
2 \%\end{array}$ & $<3 . E-3$ & $<4 . E-2$ & $<4 . E-2$ \\
\hline $\begin{array}{c}3.08 E+1 \\
4 \%\end{array}$ & $\begin{array}{c}1.08 E-1 \\
16 \%\end{array}$ & $\begin{array}{c}4.73 E-2 \\
3 \%\end{array}$ & $<2 . E-3$ & $<9 . E-2$ & $<6 . E-2$ & $<3 . E-2$ & $<2 . E-3$ & $\begin{array}{c}4.05 E+1 \\
2 \%\end{array}$ & $<3 . E-3$ & $<4 . E-2$ & $<4 . E-2$ \\
\hline $3 \%$ & $2 \%$ & $11 \%$ & & & & & & $10 \%$ & & & \\
\hline $\begin{array}{c}7.11 \mathrm{E}-1 \\
22 \%\end{array}$ & $<2 . E-1$ & $<5 . E-4$ & $<5 . E-4$ & $<5 . E-3$ & $<2 . E-3$ & $<7 . E-4$ & $<6 . E-4$ & $\begin{array}{c}7.98 \mathrm{E}-2 \\
2 \%\end{array}$ & $<2 . E-3$ & $<2 . E-3$ & $<2 . E-3$ \\
\hline $\begin{array}{c}1.22 E+3 \\
4 \%\end{array}$ & $\begin{array}{c}5.03 E+2 \\
3 \%\end{array}$ & $\begin{array}{c}1.92 E-1 \\
3 \%\end{array}$ & $<3 . E-2$ & $<3 . E-1$ & $<2 . E-1$ & $<6 . E-2$ & $<2, E-2$ & $\begin{array}{c}6.90 E+1 \\
2 \%\end{array}$ & $\begin{array}{c}1.55 E+0 \\
2 \%\end{array}$ & $\begin{array}{c}9.00 E-1 \\
5 \%\end{array}$ & $\begin{array}{c}5.78 E+0 \\
3 \%\end{array}$ \\
\hline $\begin{array}{c}1.15 E+3 \\
4 \%\end{array}$ & $\begin{array}{c}5.31 E+2 \\
3 \%\end{array}$ & $\begin{array}{l}1.90 \mathrm{E}-1 \\
.3 \%\end{array}$ & $<3 . E-2$ & $<3 . E-1$ & $\begin{array}{c}2.67 E-1 \\
20 \%\end{array}$ & $<6 . E-2$ & $<2 . E-2$ & $\begin{array}{c}6.94 \mathrm{E}+1 \\
2 \%\end{array}$ & $\begin{array}{c}1.57 E+0 \\
2 \%\end{array}$ & $\begin{array}{c}9.28 E-1 \\
5 \%\end{array}$ & $\begin{array}{c}5.76 E+0 \\
3 \%\end{array}$ \\
\hline $6 \%$ & $\begin{array}{c}5 \% \\
<2 . E-1\end{array}$ & $1 \%$ & & & & & & $1 \%$ & $1 \%$ & $3 \%$ & $0 \%$ \\
\hline $\begin{array}{l}100 \% \\
98 \%\end{array}$ & $\begin{array}{l}97 \% \\
95 \%\end{array}$ & & & & & & & & & & \\
\hline $\begin{array}{c}99 \% \\
100 \%\end{array}$ & $\begin{array}{l}92 \% \\
94 \%\end{array}$ & 1 & . & & & & & & & & \\
\hline
\end{tabular}


Client : M. Urie

Cognizant Scientist:

Concur:

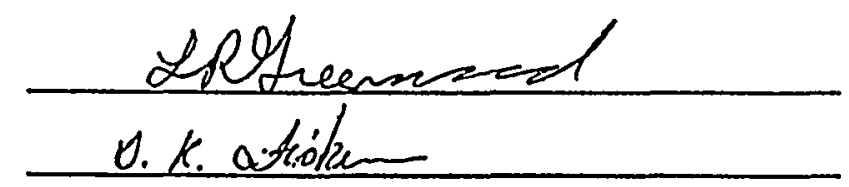

Date: $\quad 6 / 1 / 00$

Measured Activities $u \mathrm{Ci} / g$ with 1- $\sigma$ error

Date: $\quad 6 / 1 / 0^{2}$

ALO ID

Client ID

00-1360PB

Process Blank

$00-1360$ *

C-104 Supernatant Comp.

00-1360 DUP*

C-104 Supernatant Comp.

RPD

$$
\begin{array}{cr}
4.03 \mathrm{E}-3 & 1.82 \\
6 \% & 4 \% \\
4.58 \mathrm{E}-3 & 1.82
\end{array}
$$

\begin{tabular}{ccccccccc}
$\begin{array}{c}\text { Alpha } \\
\text { Error }+1-\end{array}$ & $\begin{array}{c}\text { Pu-239+ } \\
\text { Pu-240 } \\
\text { Error \% }\end{array}$ & $\begin{array}{c}\text { Pu-238 } \\
\text { Error \% }\end{array}$ & $\begin{array}{c}\text { Pu-236 } \\
\text { Error \% }\end{array}$ & $\begin{array}{c}\text { Pu-241 } \\
\text { Error \% }\end{array}$ & $\begin{array}{c}\text { Am-241 } \\
\text { Error \% }\end{array}$ & $\begin{array}{c}\text { Cm-243+ } \\
\text { Cm-244 } \\
\text { Error \% }\end{array}$ & $\begin{array}{c}\text { Cm-242 } \\
\text { Error \% }\end{array}$ & $\begin{array}{c}\text { Sum } \\
\text { Alpha } \\
\text { Error }+1-\end{array}$ \\
\hline$<1$. E-4 & $<2$. E-6 & $<2 . E-6$ & $<7 . E-7$ & $<1 . E-4$ & $<4 . E-6$ & $<2 . E-6$ & $<5$. E-7
\end{tabular}

(4.03E-3

(1.70E-4

$4.58 \mathrm{E}-3 \quad 1.82 \mathrm{E}$

1.82E-3 $\quad 1.88 \mathrm{E}-4$

$\begin{array}{lll}13 \% & 4 \% & 8 \% \\ & 0 \% & 5 \%\end{array}$

00-1361 PB

Process Blank

00-1361

$<2 . \mathrm{E}-2 \quad 1.94 \mathrm{E}-4 \quad 2.26 \mathrm{E}-4$

$$
34 \% \quad 40 \%
$$

$9.80 E+0 \quad 5.02 E+0 \quad 5.77 E-1<3 . E-3$

C-104 Centrifuged Solids Comp.

00-1361 Dup

C-104 Centrifuged Solids Comp.

$\begin{array}{ccc}1.03 E+1 & 4.89 E+0 & 5.81 E-1 \\ 3 \% & 4 \% & 5 \%\end{array}$

$5 \% \quad, \quad 3 \%$

$5 \%$

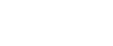

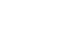

$1 \%$

$<2 . E-2$

$<7 . \mathrm{E}-5$

$<5 . E-5$

$<9 . E-7<2 . E-6$

$<4 . E-7$

Liquids Blank

Matrix Spike

$92 \%$

$95 \%$

$103 \%$

5.07E-3 2.01E-3

$4.23 \mathrm{E}-5$

5.73E-6

4.06E-3

$9 \% \quad 5 \% \quad 15 \% \quad 40 \%$

$5.11 \mathrm{E}-3 \quad 2.02 \mathrm{E}-3$

$3.81 E-5$

$1.02 E-5$

4.08E-3

$9 \% \quad 5 \% \quad 16 \% \quad 31 \%$

$1 \% \quad 0 \% \quad 10 \% \quad 56 \% \quad 0 \%$

Blank Spike

$105 \% \quad 103 \%$

$109 \% \quad 101 \%$

$101 \%$

- $9 . \mathrm{E}-3$

$0 \%$

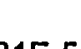

$<4 . E-5$

$1.00 \mathrm{E}-3$

$49 \%$

$1.39 \mathrm{E}+1 \quad 5.54 \mathrm{E}+0$

$8 \% \quad 5 \%$

$5.83 \mathrm{E}-2$

$1.51 \mathrm{E}-2$

$1.12 E+1$

$15 \%$

$28 \%$

1.11E+1

$\begin{array}{cccc}74 \mathrm{E}+1 & 5.50 \mathrm{E}+0 & 7.75 \mathrm{E}-2 & 9.37 \mathrm{E}-3 \\ 8 \% & 5 \% & 12 \% & 33 \%\end{array}$

$22 \% \quad 1 \% \quad 28 \% \quad 47 \%$

$1 \%$

Note: * Data for sample 00-1360 are reported as $\mathrm{uCi} / \mathrm{ml}$ 
Chemical Measurements Center

Client: M. Urie

Cognizant Scientist:

Concur :

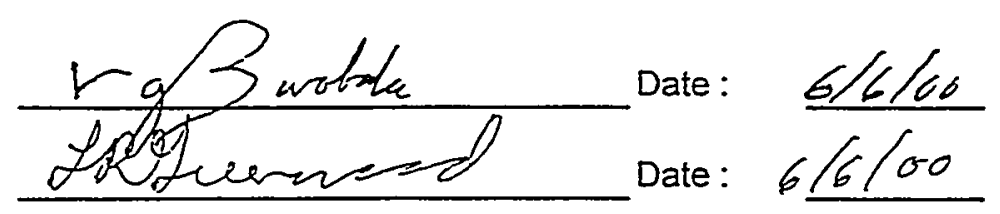

Measured Activities with 1- $\sigma$ error

เ

ALO ID

Client ID

00-1360

C-104 Supernatant Comp.

00-1360 rep

C-104 Supernatant Comp.

RPD

00-1361 PB

Process blank

00-1361

C-104 Centrifuged Solids Comp.

00-1361 dup

C-104 Centrifuged Solids Comp.

00-1361 dup rep

C-104 Centrifuged Solids Comp.

RSD

Liquids blank

Solids blank
Se-79

Error \%

$6.41 \mathrm{E}-5 \quad \mu \mathrm{Ci} / \mathrm{ml}$

$4 \%$

$6.50 \mathrm{E}-5 \quad \mu \mathrm{Ci} / \mathrm{ml}$

$5 \%$

$1 \%$

$<7 . \mathrm{E}-4 \quad \mu \mathrm{Ci} / \mathrm{g}$

6.43E-3 $\quad \mu \mathrm{Ci} / \mathrm{g}$

$6 \%$

$6.66 \mathrm{E}-3 \quad \mu \mathrm{Ci} / \mathrm{g}$

$6 \%$

9.94E-3 $\quad \mu \mathrm{Ci} / \mathrm{g}$

$6 \%$

$26 \%$

$<2 . \mathrm{E}-6 \quad \mu \mathrm{Ci} / \mathrm{ml}$

$<9 . \mathrm{E}-4 \quad \mu \mathrm{Ci} / \mathrm{g}$ 
Battelle Pacific Northwest Laboratory

Radiochemical Processing Group-325 Building

Chemical Measurements Center
$00-1360 \mathrm{H3}$

$7 / 12 / 2000$

Rev. 1

Client: M. Urie

Cognizant Scientist:

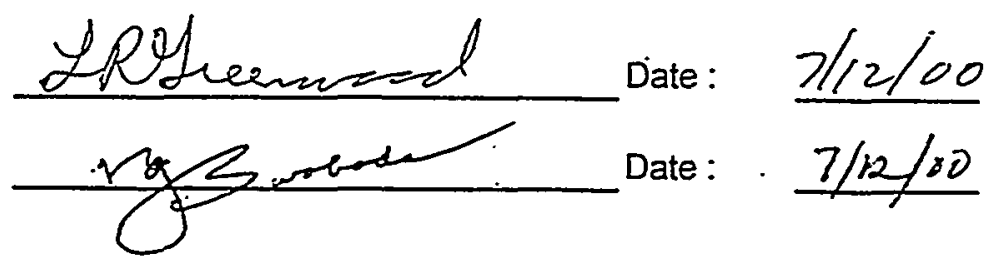

Measured Activities with 1- $\sigma$ error

,

ALO ID

Tritium*

Client ID

Error \%

00-1360

C-104 Supernatant Comp.

4.53E-3 $\quad \mu \mathrm{Ci} / \mathrm{ml}$

$4 \%$

00-1360

C-104 Supernatant Comp.

4.81E-3 $\quad \mu \mathrm{Ci} / \mathrm{ml}$

$4 \%$

$6 \%$

00-1361

C-104 Centrifuged Solids Comp.

5.93E-2 $\quad \mu \mathrm{Ci} / \mathrm{g}$

$5 \%$

00-1361 Dup

C-104 Centrifuged Solids Comp.

1.14E-2 $\quad \mu \mathrm{Ci} / \mathrm{g}$

$5 \%$

$136 \%$

RPD

$-$

00-1361 PB

Process Blank

$1.28 \mathrm{E}-2 \quad \mu \mathrm{Ci} / \mathrm{g}$

$4 \%$

1

Solids Blank

$<4 . E-4 \quad \mu \mathrm{Ci} / \mathrm{g}$

Liquid Blank

$<1 . \mathrm{E}-4 \quad \mu \mathrm{Ci} / \mathrm{ml}$

Liquid blank spike

$95 \%$

Solids blank spike

$103 \%$

*For the solids, tritium is reported per gram of wet slurry. 
Chemical Measurements Center

Client: M. Urie

Cognizant Scientist:

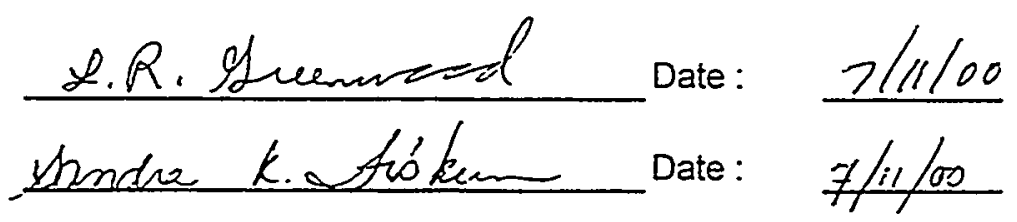

Concur:

Measured Activities with 1- $\sigma$ error

\begin{tabular}{|c|c|c|}
\hline $\begin{array}{l}\text { ALO ID } \\
\text { Client ID } \\
\end{array}$ & $\begin{array}{l}\text { C-14* } \\
\text { Error \% }\end{array}$ & \\
\hline $00-1360$ & $7.70 E-4$ & $\mu \mathrm{Ci} / \mathrm{ml}$ \\
\hline C-104 Supernatant Comp. & $5 \%$ & \\
\hline $\begin{array}{l}\text { 00-1360 } \\
\text { C-104 Supernatant Comp. }\end{array}$ & $\begin{array}{c}7.71 E-4 \\
5 \%\end{array}$ & $\mu \mathrm{Ci} / \mathrm{ml}$ \\
\hline RPD & $0 \%$ & \\
\hline $\begin{array}{l}\text { 00-1361 } \\
\text { C-104 Centrifuged Solids Comp. }\end{array}$ & $\begin{array}{c}1.12 \mathrm{E}-3 \\
7 \%\end{array}$ & $\mu \mathrm{Ci} / \mathrm{g}$ \\
\hline $\begin{array}{l}\text { 00-1361 Dup } \\
\text { C-104 Centrifuged Solids Comp. }\end{array}$ & $\begin{array}{c}1.28 E-3 \\
7 \%\end{array}$ & $\mu \mathrm{Ci} / \mathrm{g}$ \\
\hline RPD & $13 \%$ & \\
\hline Blank (as liquid) & $<4 . E-7$ & $\mu \mathrm{Ci} / \mathrm{ml}$ \\
\hline Blank spike & $96 \%$ & \\
\hline Liquid matrix spike & $97 \%$ & \\
\hline Solids matrix spike & $88 \%$ & \\
\hline
\end{tabular}

*For the solids, tritium is reported per gram of wet slurry. 


\section{Battelle}

Pacific Northwest Laboratories

Date 21 August 2000

To

Mike Urie

Sandra Fiskum

From

Charles J. Barinaga

509-376-6095

Chalbif. Barinaga 8/22/00

Subject

ICP/MS Analyis of C104 Samples (ALO\# 001360 and 001361

This report contains our responses to Sandra Fiskum's questions concerning the data in the previous report on this work submitted by Tom Farmer on 06 June 2000. It also contains data for isotopes inadvertently left out in the previous report and revises . (indicated by asterisks) some data mis-reporting due to data handling errors that weren't caught in the report preparation and review.

The data left out of the previous report and included here are for U-236 and Np-237 for the supernatant acid digest and for Cs-135 and 137 for the supernatant, water dilution and acid digest, and for the $\mathrm{KOH}$ fused solids. (Our term for the 'supernatant water dilution' data set is "direct.")

Also included, at Sandra's request, are the MDL's for the individual samples. (The MDL's are the dilution factor and density adjusted equivalent concentrations of $5 X$ SD of the Hlank
for that element/isotope from three acquisitions.) The nominal values are reported below. Please see the summary sheets for the actual MDL for each sample.

\begin{tabular}{|l|l|l|l|l|l|l|l|l|l|}
\hline MDL's & Rb & Tc & I-127 & I-129 & Cs & Pr & Ta & 233 & 234 \\
\hline acid & .0006 & $3.4 \mathrm{E}-5$ & 0.002 & $1 \mathrm{E}-6$ & 0.004 & 0.001 & 0.002 & $2 \mathrm{E}-5$ & $6 \mathrm{E}-6$ \\
\hline direct & 0.003 & $1.7 \mathrm{E}-4$ & 0.12 & $3 \mathrm{E}-5$ & 0.01 & 0.005 & & & \\
\hline fusion & 0.5 & 0.002 & 0.6 & $2.4 \mathrm{E}-4$ & 0.3 & 0.4 & 0.12 & $6.8 \mathrm{E}-3$ & $7 \mathrm{E}-3$ \\
\hline & & & & & & & & & \\
\hline & 235 & 236 & 238 & tot. U & Np & 239 & 240 & & \\
\hline acid & $4 \mathrm{E}-8$ & $8 \mathrm{E}-8$ & $2 \mathrm{E}-7$ & 0.02 & $2.4 \mathrm{E}-6$ & $2.5 \mathrm{E}-5$ & $1.3 \mathrm{E}-4$ & & \\
\hline direct & $5 \mathrm{E}-8$ & $4 \mathrm{E}-7$ & $8 \mathrm{E}-8$ & 0.2 & $3.7 \mathrm{E}-7$ & $4.8 \mathrm{E}-4$ & $2.7 \mathrm{E}-3$ & & \\
\hline fusion & $1.7 \mathrm{E}-5$ & $7.8 \mathrm{E}-5$ & $3.5 \mathrm{E}-7$ & 80 & $3 \mathrm{E}-4$ & $2.6 \mathrm{E}-2$ & $3.8 \mathrm{E}-2$ & & \\
\hline
\end{tabular}


The data revisions include:

Direct (water dilution):

- Small decrease in the 'direct' Pu-239 and 240 values due to correction of dilution factors.

- Transcription errors in the Np-237 and Pr blank values, see below.

Acid Digest:

- 1-129 matrix spike - transcription error.

- Under-estimate of Pu-240 due to offset in 239 calibration. Corrected

KOH Fusion: by using the lowest 239 standard to estimate 240 .

- Radionuclides for SRM 2710 originally reported as ug/g, now corrected to $u$ Ci/g.

- Ta process blank - a transcription error originally reported as $0.4 \mathrm{ug} / \mathrm{g}$, the correct value is $<0.14 \mathrm{ug} / \mathrm{g}$ (the reporting limit).

Responses to questions from Sandra:

'Direct' (supernatant water dilution)

- $\mathrm{Np}-237$ value for the diluent blank was listed as $2.8 \mathrm{E}-4 \mathrm{uCi} / \mathrm{mL}$. It should have been $2.8 \mathrm{E}-7 \mathrm{uCi} / \mathrm{mL}$. (a ppm vs ppb units error in data entry)

- Pr for the diluent ('direct') blank $(0.14 \mathrm{ug} / \mathrm{mL}$ ) is higher than for the samples. There was a transcription error from the calculation sheet to the summary page. The actual $\mathrm{Pr}$ blank value should be $0.03 \mathrm{ug} / \mathrm{mL}$.

$\mathrm{Ni} / \mathrm{KOH}$ fusion (solids $\mathrm{KOH}$ fusion)

$\mathrm{Rb}$ for the process blank is nearly as high as that in the samples. That $\mathrm{Rb}$ is high due to the process is also reflected in the value for SRM 2710, 447 ug/g, which is higher than the "suggested" (not certified) value of $120 \mathrm{ug} / \mathrm{g}$. A significant level of $\mathrm{Rb}$ in the process blank was also noted in the screening ICP/MS acquisition.

High RSD's for 'acid digest' Ta and Pu-240 and for 'direct' Pu-239 and 240. Although the reported values are above the reporting limits, these were low count responses and had more noise during the acquisition.

High RPD's - especially for several 'direct' elements/isotopes

The analyst, James Bramson, noted these differences and reprepped/reran the samples with the same result. Unfortunately in our current data acquisition scheme, these efforts and data are not captured. We have no explanation except to note that the more soluble elements, e.g. Rb, Tc, l, Cs, do not show this difference.

Pu 240/239 ratio differences within and between acid digest, direct, and fusion. Since we do not have a 240 standard, Pu-240 was determined by reference to the 239 calibration. An offset in the 239 calibration curve at low concentrations for the 'acid digest' under-estimates the 240 concentration (reported values 361 and $475 \mathrm{uCi} / \mathrm{mL}$ ). When determined 
from a 239 calibration limited to the low concentration standard, the 240 values are 645 and $655 \mathrm{uCi} / \mathrm{mL}$.

Sum Pu $239+240$ vs rad counting

The 239-240 rad counting vs. the sum $(239,240)$ ICP/MS values for the $\mathrm{KOH}$ Fusion agree well, however those for the Acid Digest do not. We have no explanation for this. Also there is a difference between the Acid Digest and the Water Dilution sum values. Again we have no explanation except to note that there are inconsistencies with Water Dilution values, this may be due to solubility problems.

Sum $U$ isotopes between 'direct' sample and duplicate Again this is related to the general inconsistency between the 'sample' and the 'duplicate' solutions for the Water Dilution batch.

I believe this fills out the data and covers your questions. The reviewed sheets and data package will follow later today. Please call if there are additional questions. 

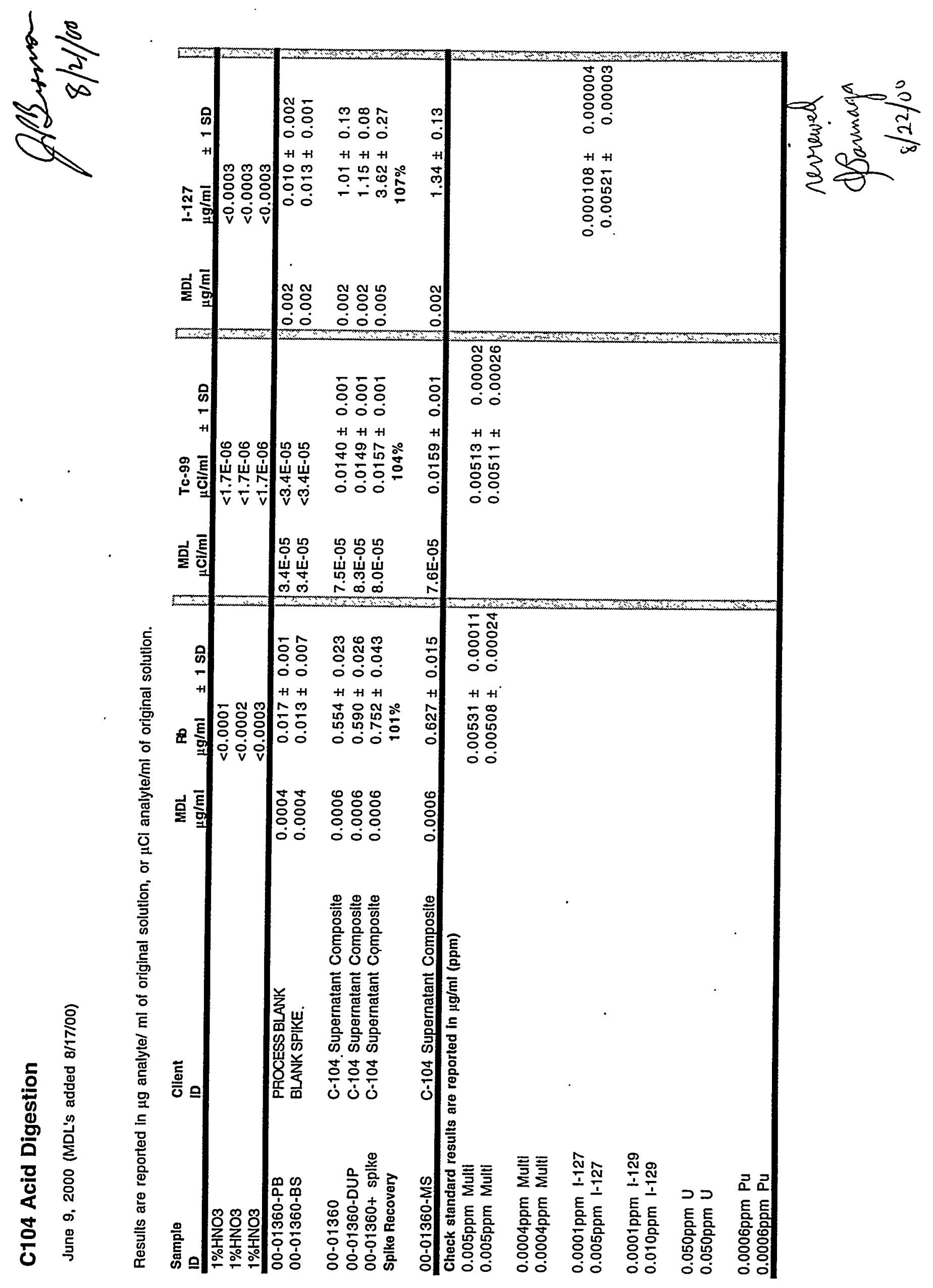


\section{C104 Acid Digestion}

June 9, 2000 (MDL's added 8/17/00, *revised 8/17/00)

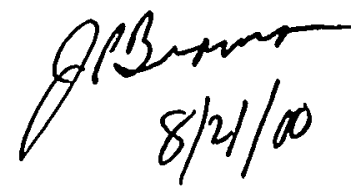

Results are reported in $\mu \mathrm{g}$ analyte/ $\mathrm{ml}$ of original solution, or $\mu \mathrm{Ci}$ analyte/ml of original solution.

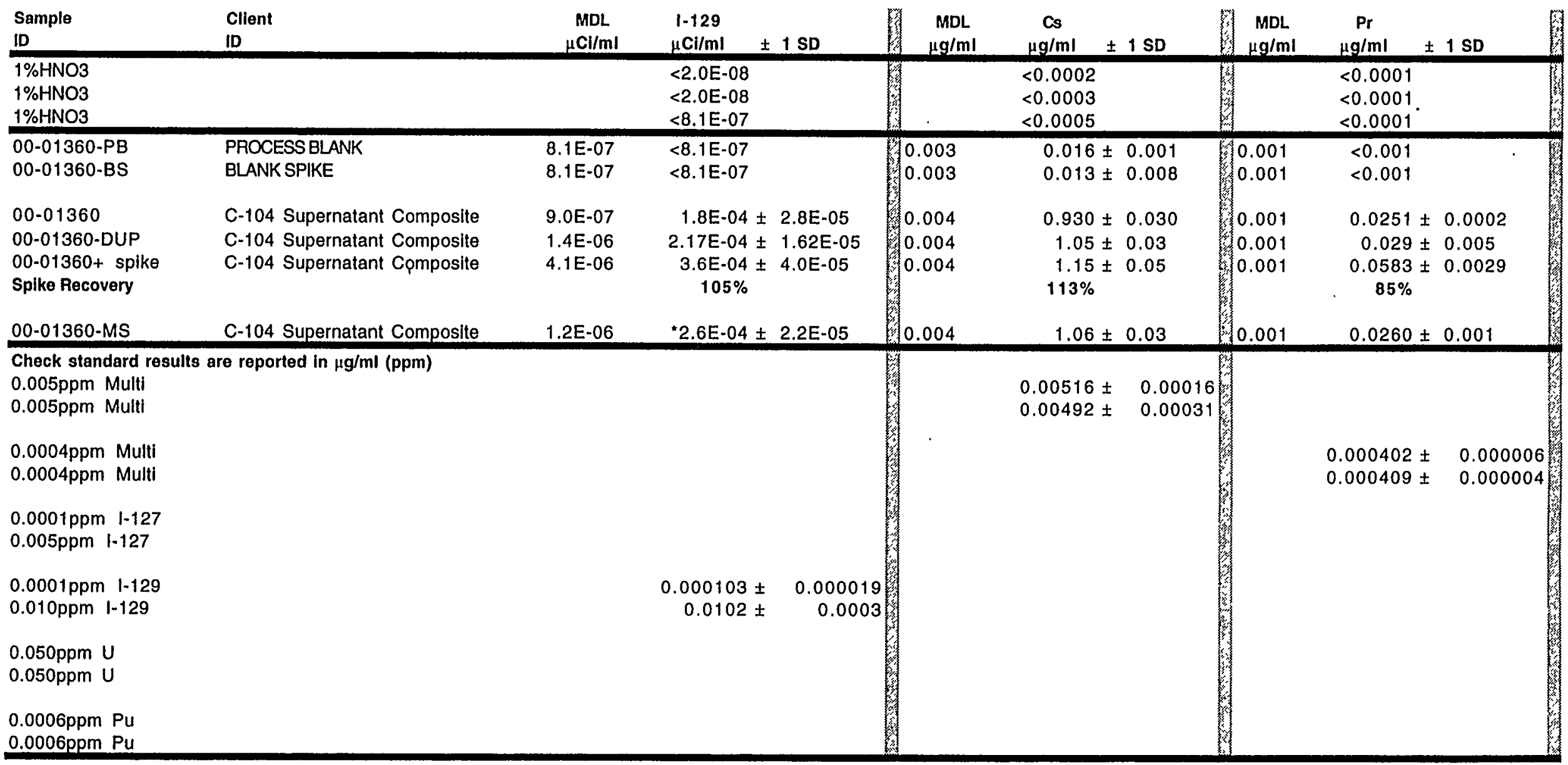

$0.0006 \mathrm{ppm} \mathrm{Pu}$

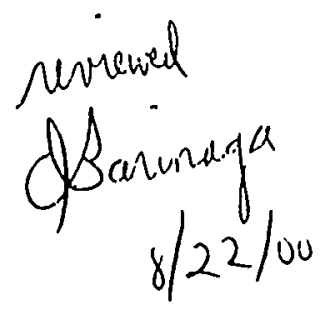




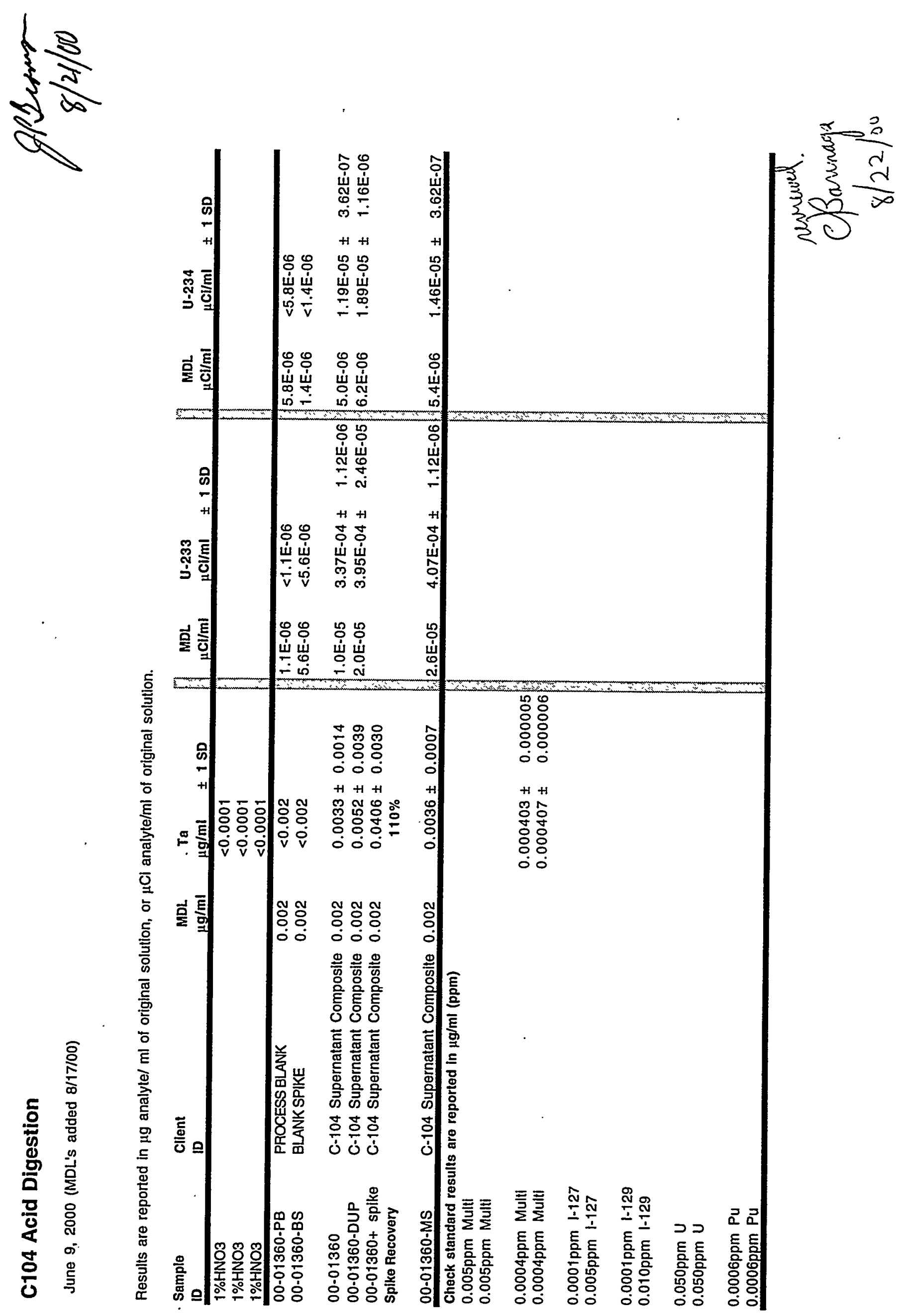




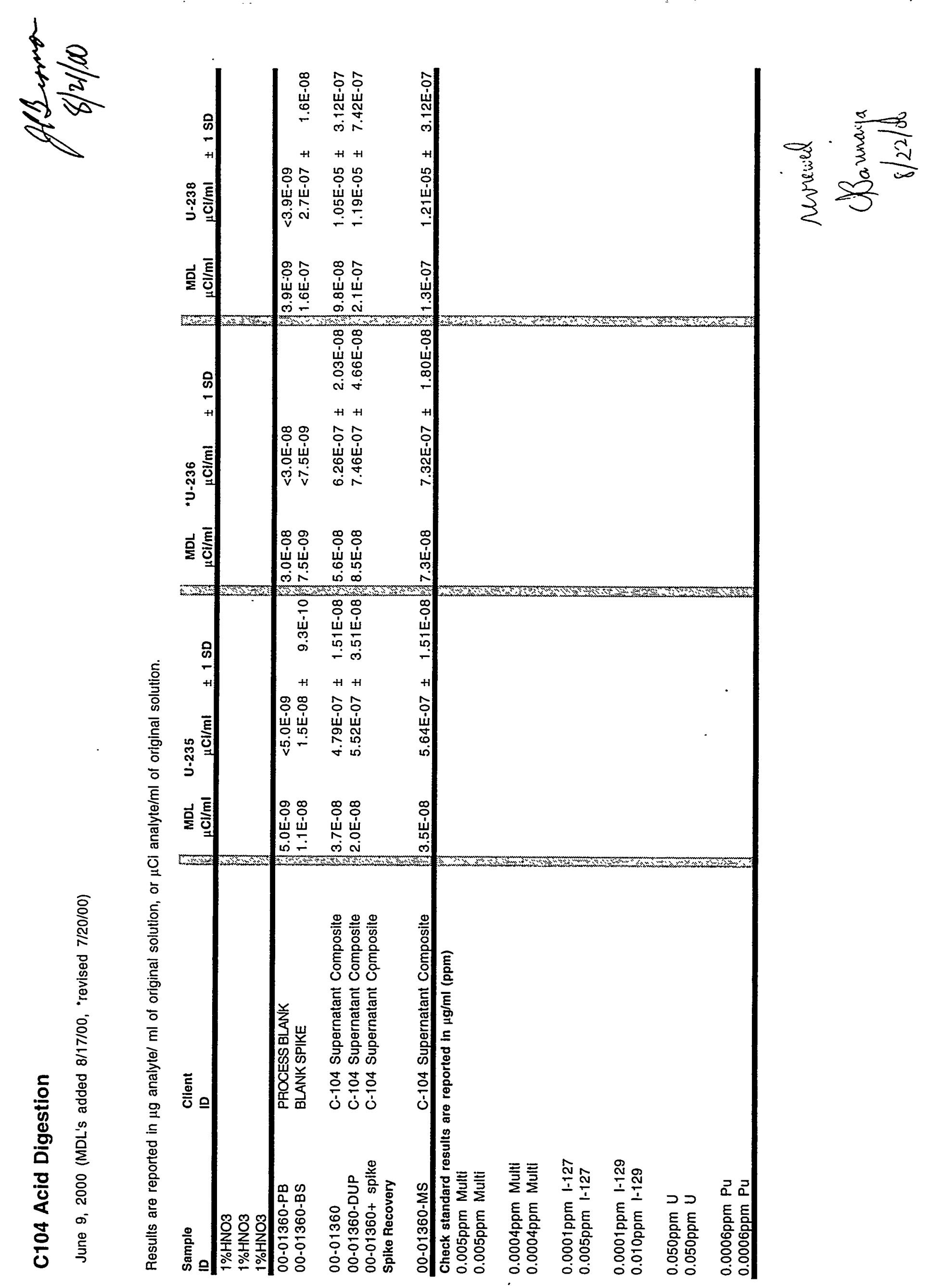




\section{C104 Acid Digestion}

June 9, 2000 (MDL's added 8/17/00, "revised 7/20/00)

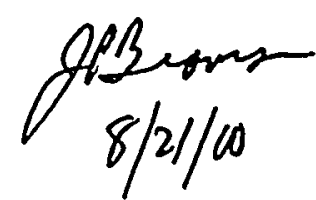

Results are reported in $\mu \mathrm{g}$ analyte/ $\mathrm{ml}$ of original solution, or $\mu \mathrm{Cl}$ analyte/ml of original solution.

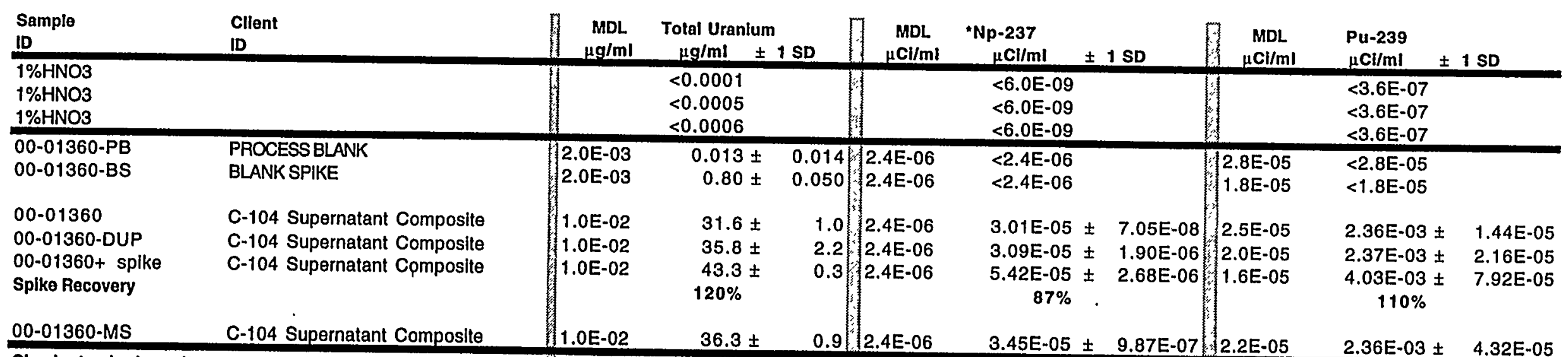

Check standard results are reported in $\mu \mathrm{g} / \mathrm{ml}$ (ppm)

$0.005 \mathrm{ppm}$ Multi

$0.005 p p m$ Multi

$0.0004 p p m$ Multi

$0.0004 \mathrm{ppm}$ Multi

$0.0001 \mathrm{ppm} \quad \mathrm{l}-127$

$0.005 p p m \quad$ I-127

$0.0001 \mathrm{ppm} \quad 1-129$

$0.010 \mathrm{ppm} 1-129$

$0.050 \mathrm{ppm} U$

$0.050 \mathrm{ppm} U$

$0.0477 \pm 0.0013$

$0.0479 \pm 0.0010$

$0.000398 \pm 0.000010)$

$0.000595 \pm 0.000020$ $0.000594 \pm 0.000011$

$0.0006 \mathrm{ppm} \mathrm{Pu}$

$0.0006 \mathrm{ppm} \mathrm{Pu}$

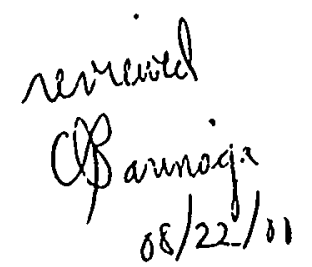




\section{C.104 Acid Digestion}

June 9, 2000 (MDL's added 8/17/00, "revised 8/17/00)

Results are reported in $\mu \mathrm{g}$ analyte/ $\mathrm{ml}$ of original solution, or $\mu \mathrm{Cl}$ analyte/ml of original solution.

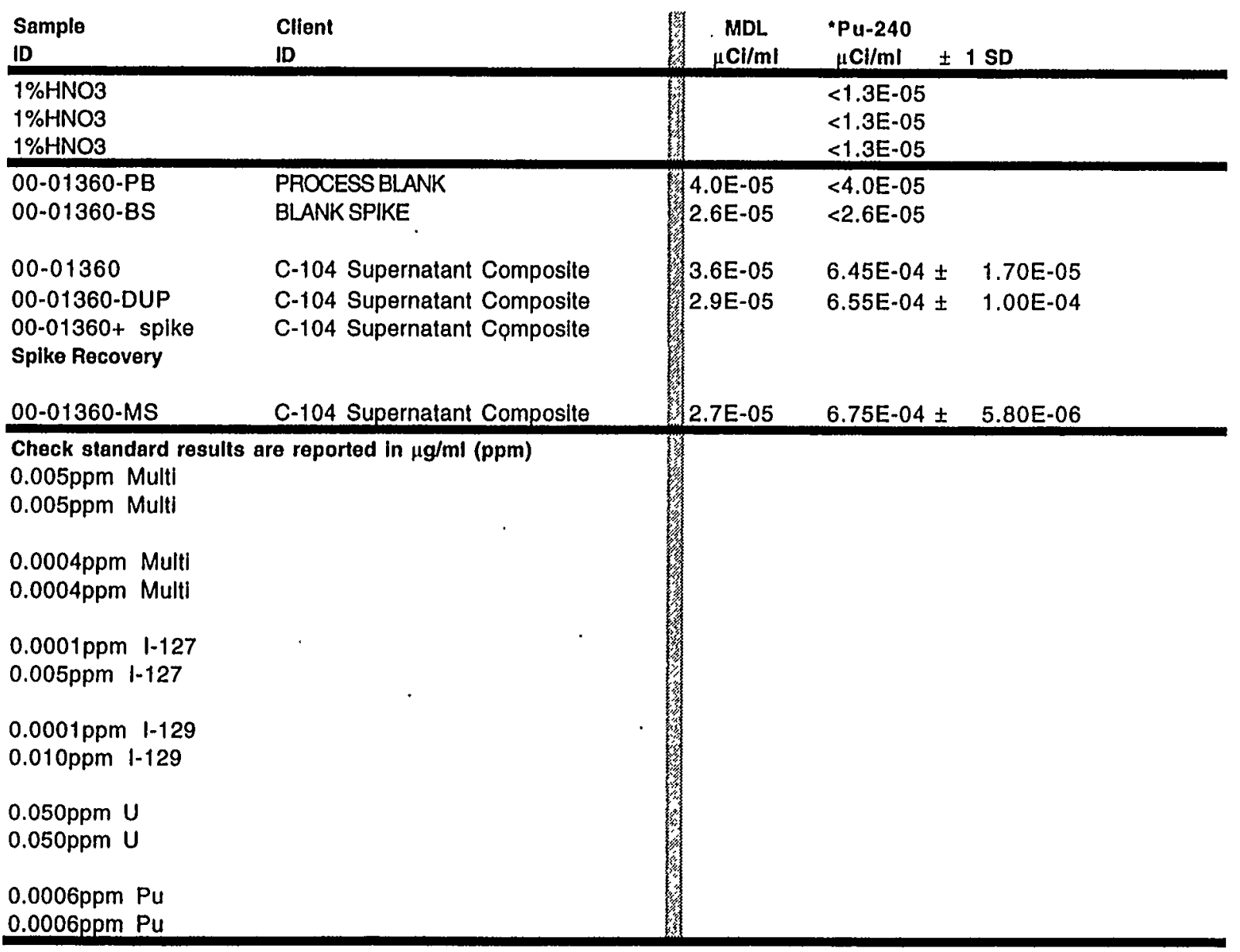

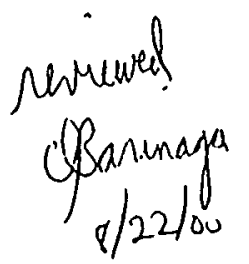



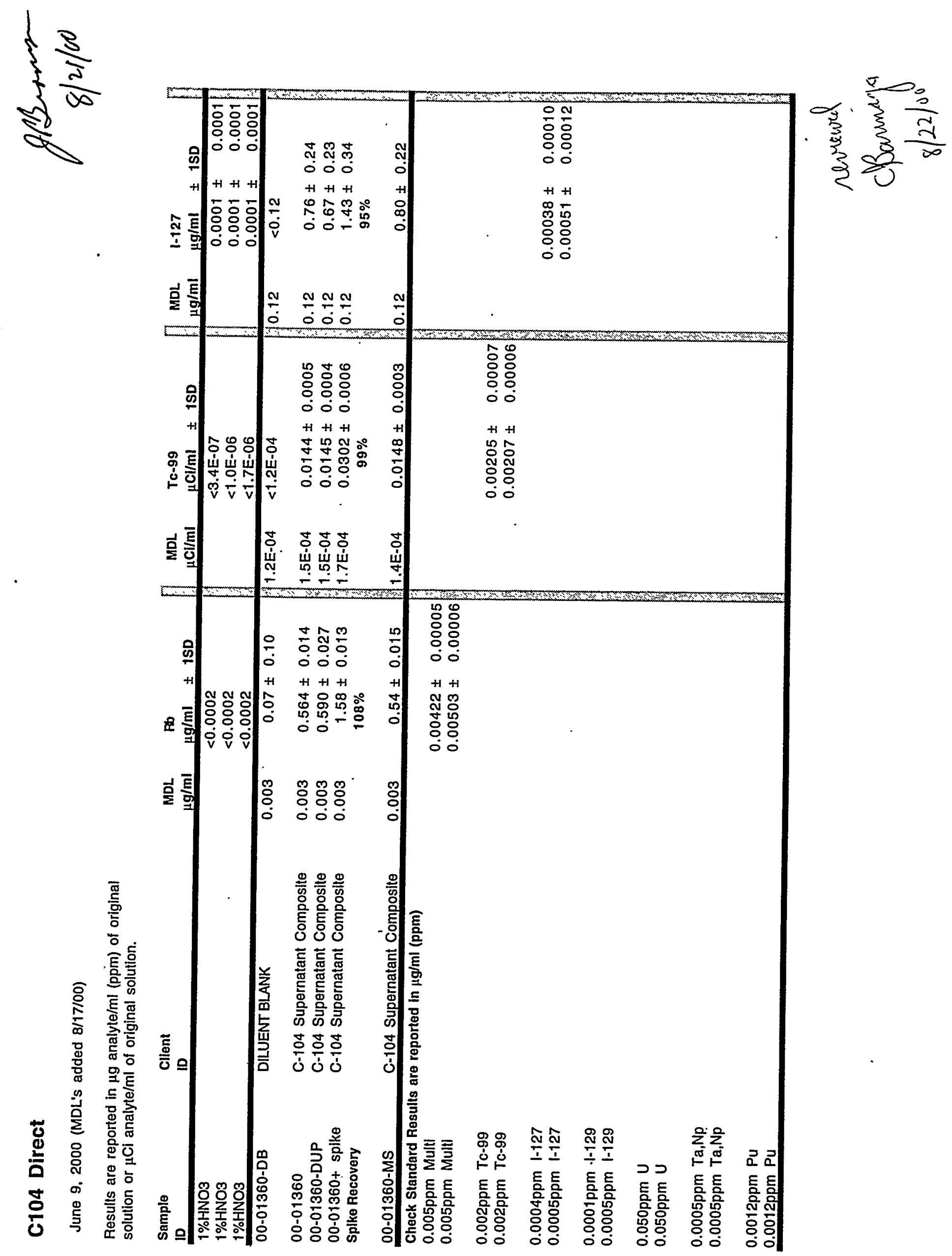

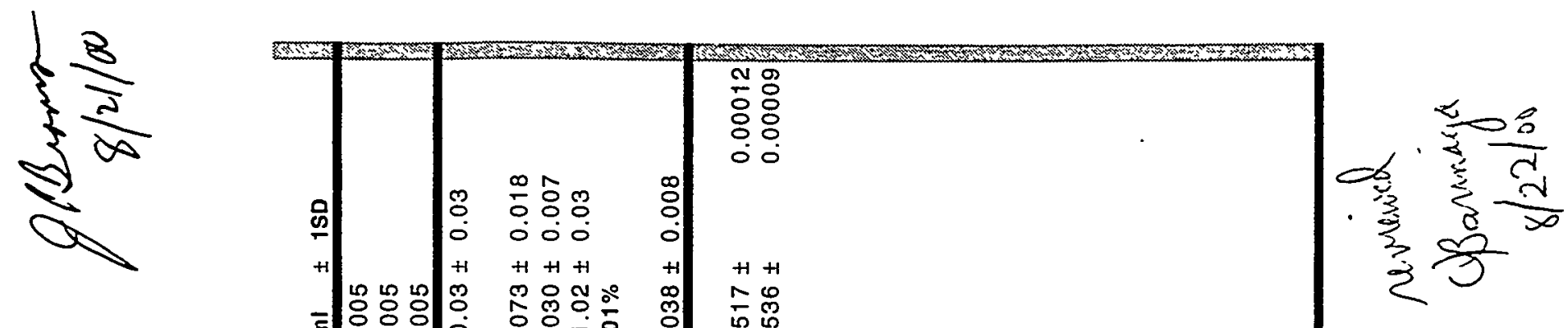


\section{C104 Direct}

June 9, 2000 (MDL's added 8/17/00, "revised 8/17/00)

Results are reported in $\mu \mathrm{g}$ analyte/ml (ppm) of original solution or $\mu \mathrm{Cl}$ analyte $/ \mathrm{ml}$ of orlginal solution.

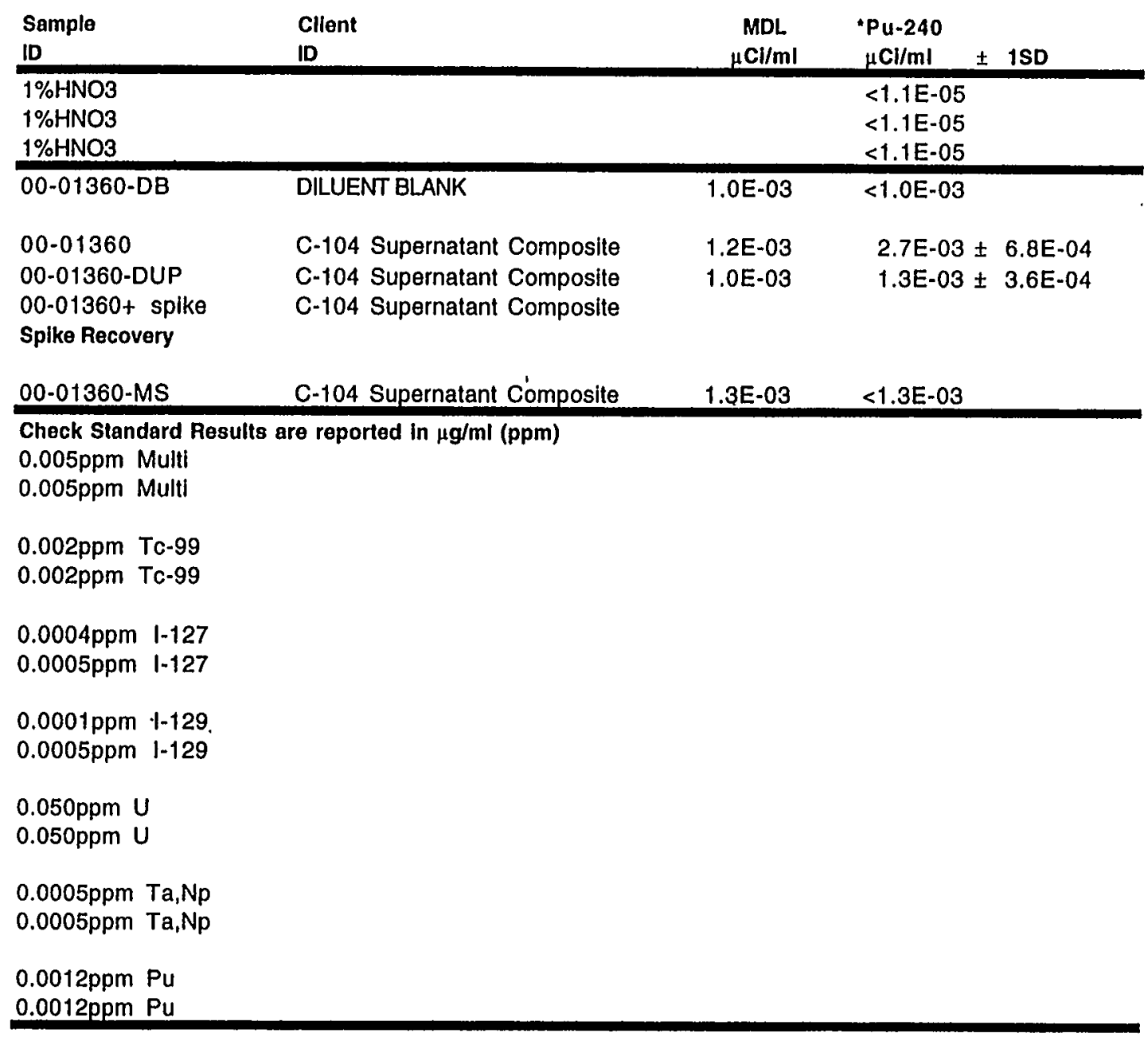

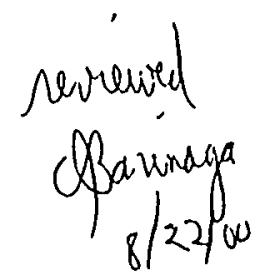




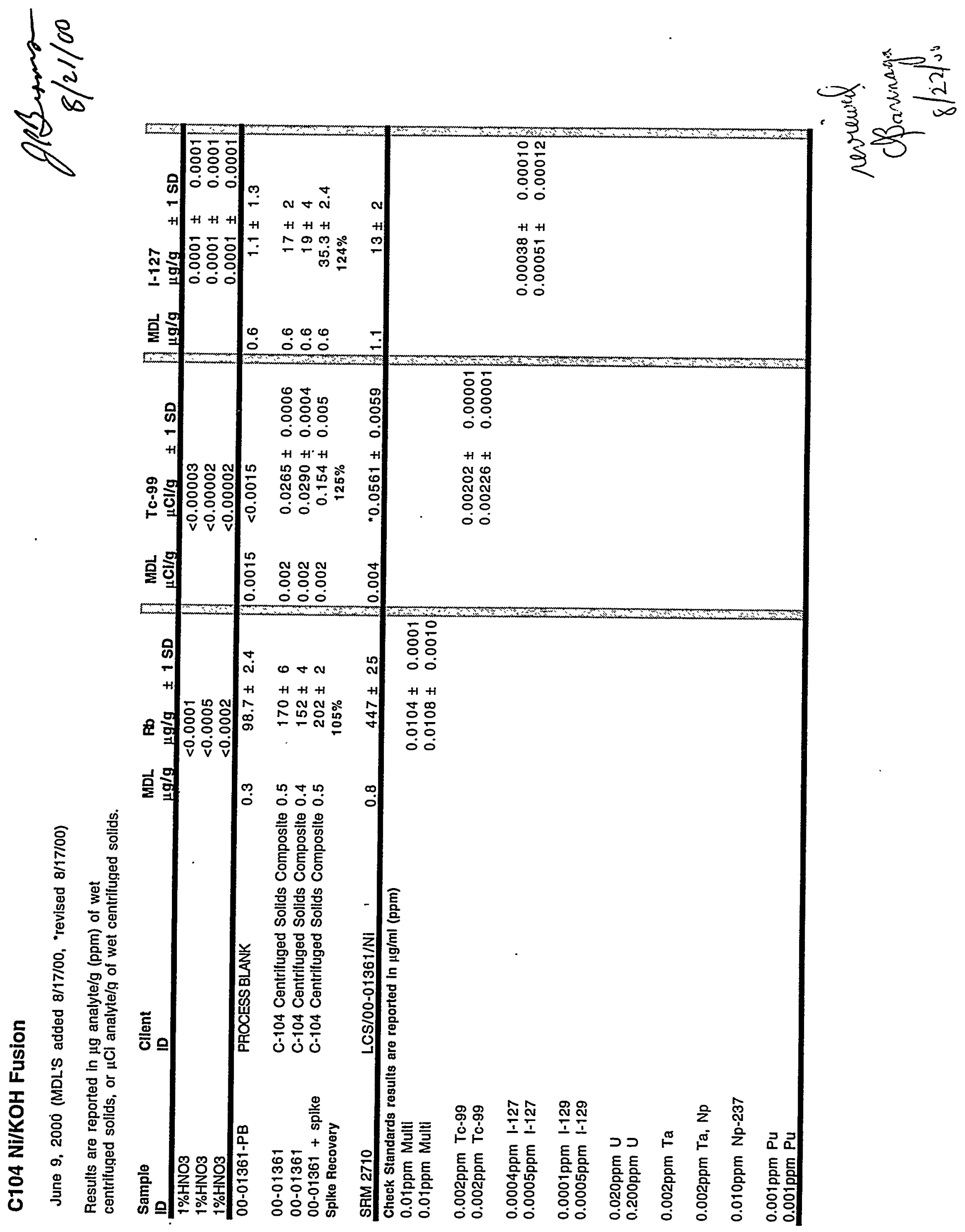




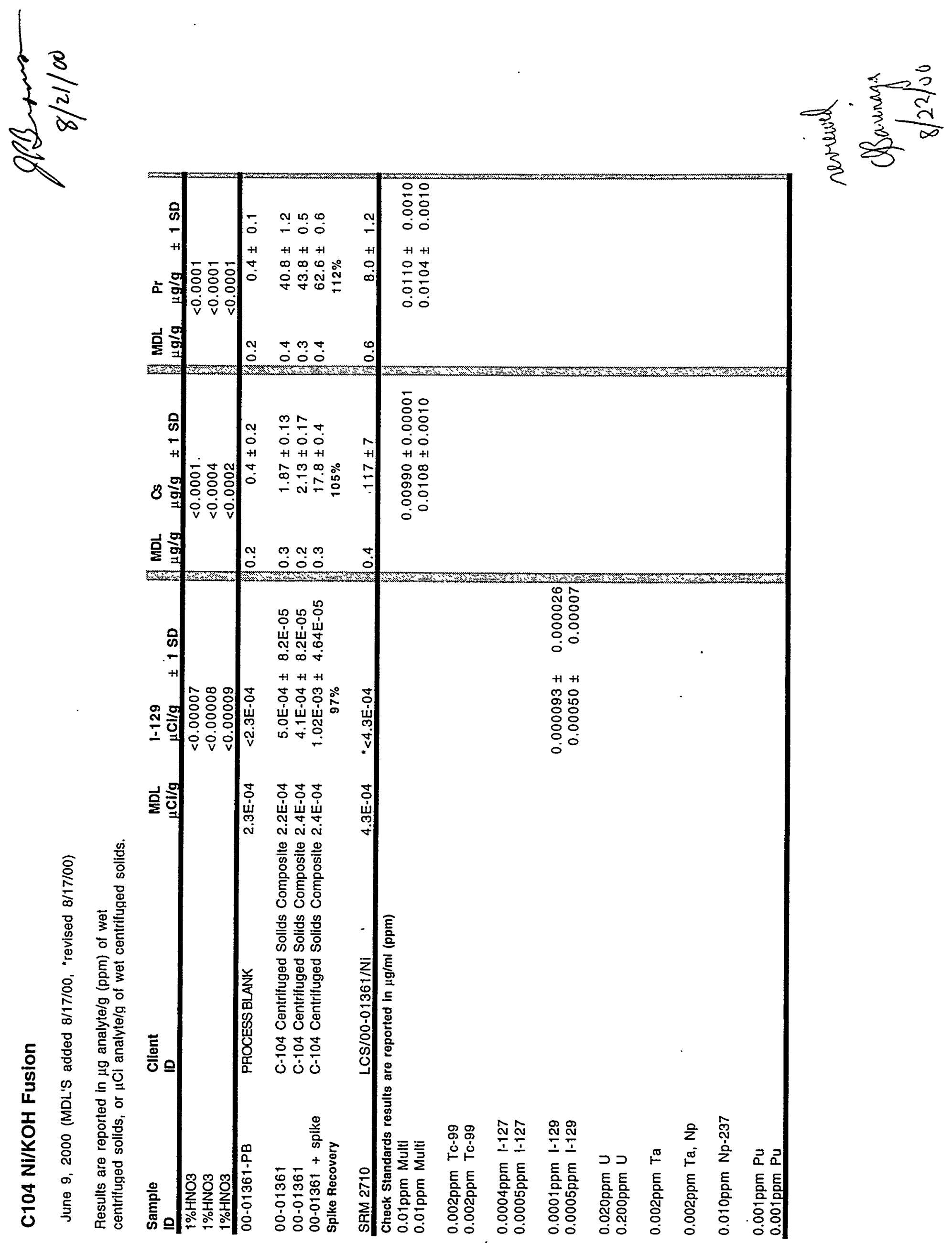




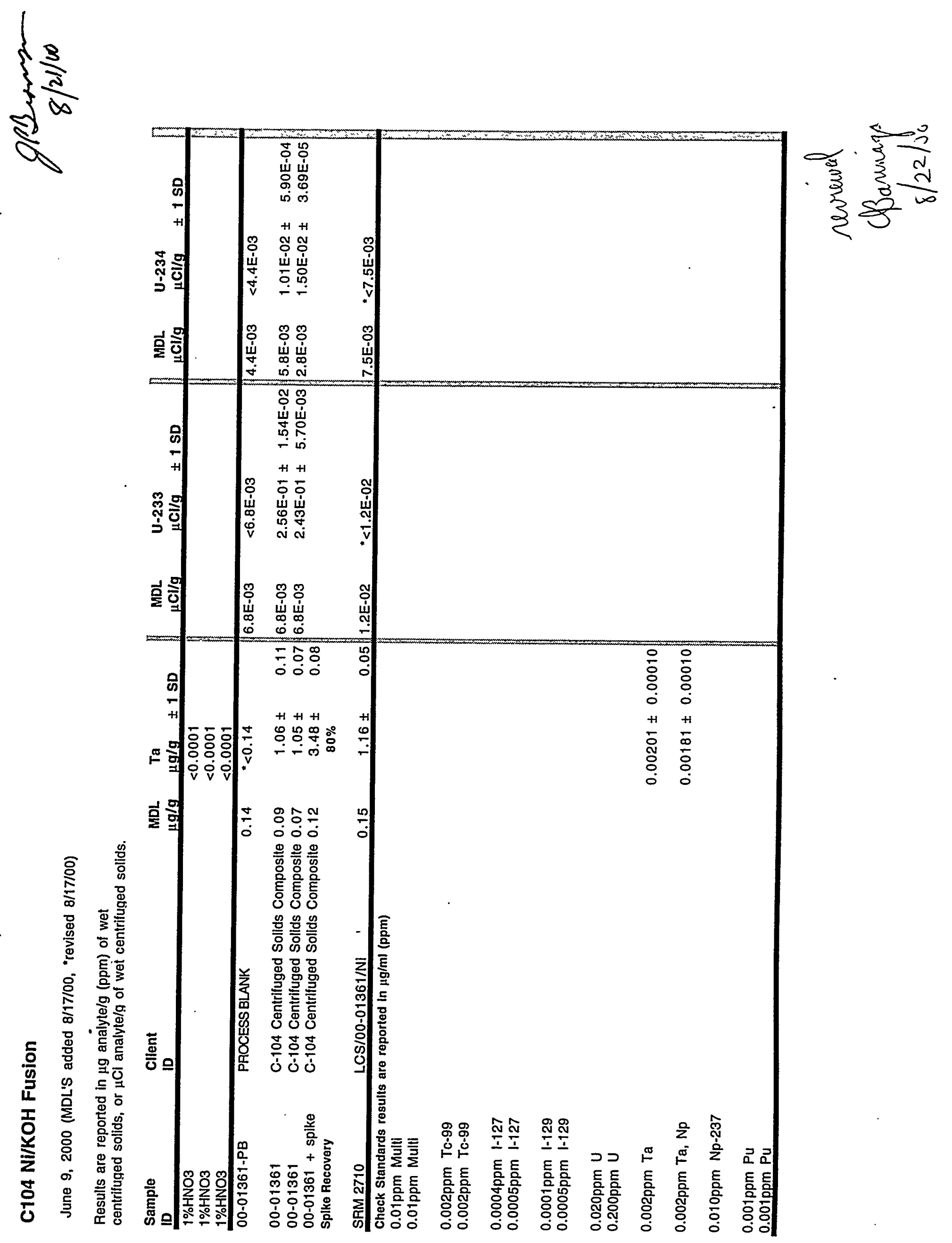




\section{C104 Ni/KOH Fusion}

June 9, 2000 (MDL'S added 8/17/00, "revised 8/17/00)

Results are reported in $\mu \mathrm{g}$ analyte/g (ppm) of wet

centrifuged solids, or $\mu \mathrm{Cl}$ analyte/g of wet centrifuged solids.

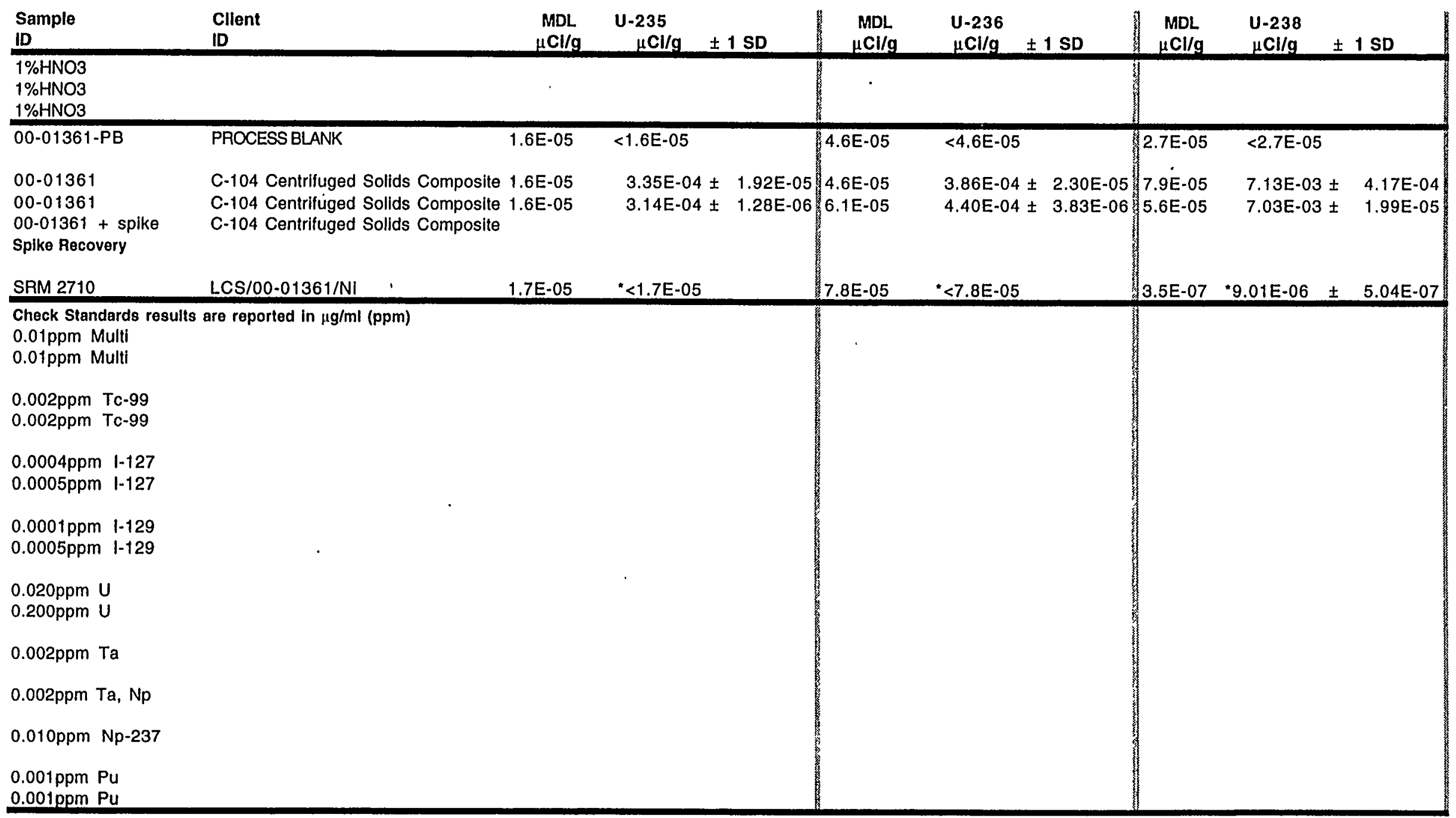

$0.001 \mathrm{ppm} P u$

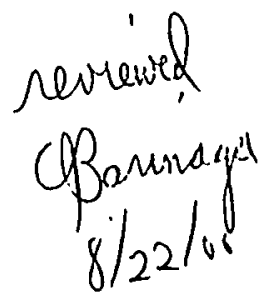




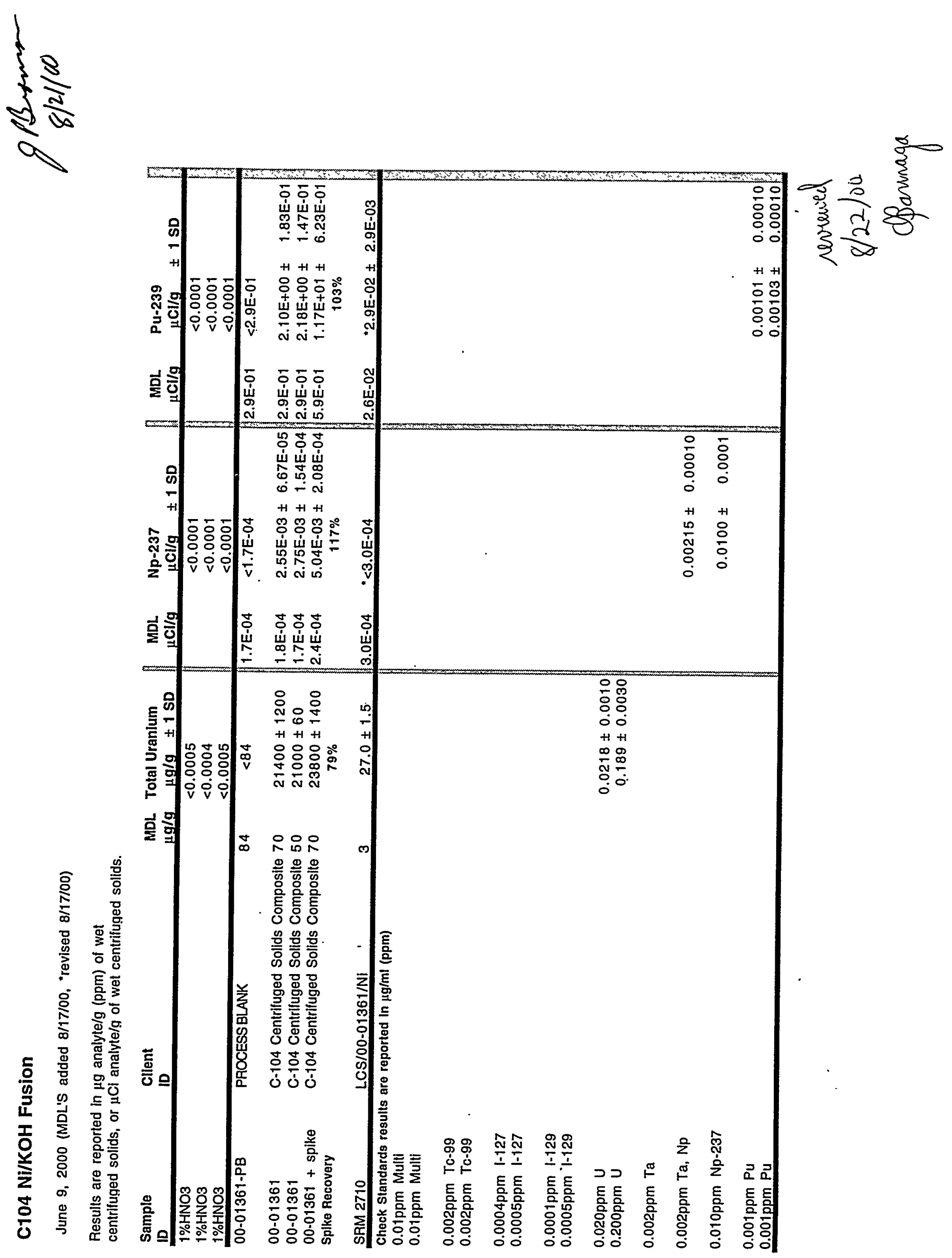




\section{C104 Ni/KOH Fusion}

June 9, 2000 (MDL'S added 8/17/00, "revised 8/17/00)

Results are reported in $\mu \mathrm{g}$ analyte/g (ppm) of wet

centrifuged solids, or $\mu \mathrm{Cl}$ analyte/g of wet centrifuged solids.

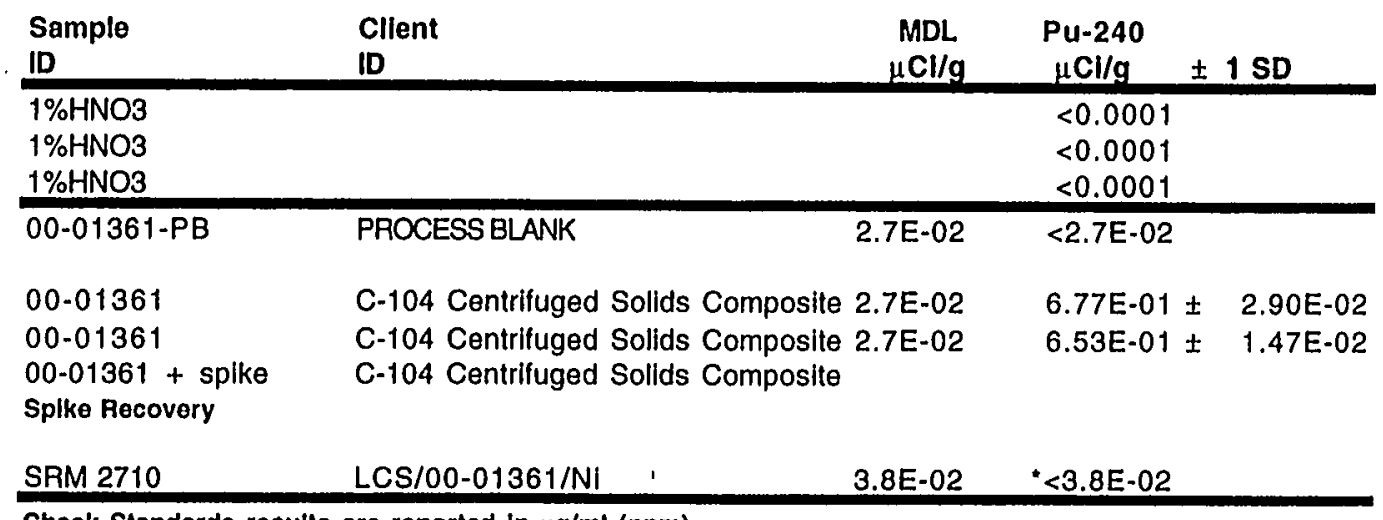

Check Standards results are reported $\ln \mu \mathrm{g} / \mathrm{ml}$ (ppm)

$0.01 \mathrm{ppm}$ Multi

$0.01 \mathrm{ppm}$ Multi

$0.002 p p m$ Tc-99

$0.002 \mathrm{ppm}$ Tc-99

$0.0004 \mathrm{ppm} \quad 1-127$

$0.0005 p p m \quad 1-127$

$0.0001 \mathrm{ppm} \quad 1-129$

$0.0005 \mathrm{ppm} \quad \mathrm{l}-129$

$0.020 p p m U$

$0.200 p p m U$

$0.002 p p m$ Ta

$0.002 p p m$ Ta, Np

$0.010 p p m ~ N p-237$

$0.001 \mathrm{ppm} \mathrm{Pu}$

$0.001 \mathrm{ppm} \mathrm{Pu}$

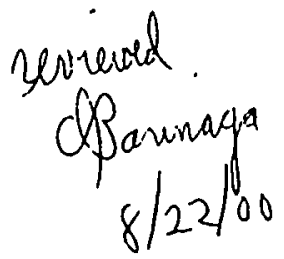




\section{C104 Platinum \\ June 9, 2000 (MDL's added 8/17/00)}

Results are reported in $\mu \mathrm{g}$ analyte/g (ppm) wet centrifuged solids

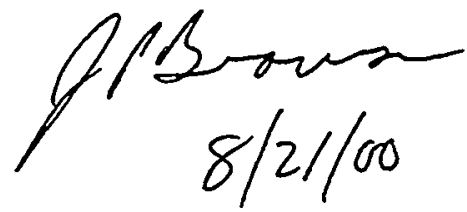

seritewed.

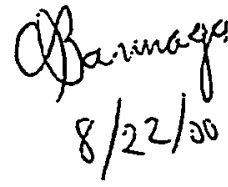

\begin{tabular}{|c|c|c|c|c|}
\hline $\begin{array}{l}\text { Sample } \\
\text { ID }\end{array}$ & $\begin{array}{l}\text { Client } \\
\text { ID }\end{array}$ & $\begin{array}{c}\mathrm{MDL} \\
\mu \mathrm{g} / \mathrm{g}\end{array}$ & $\begin{array}{c}\mathrm{Pt} \\
\mu \mathrm{g} / \mathrm{g}\end{array}$ & \\
\hline $\begin{array}{l}1 \% \text { HNO3 } \\
1 \% \text { HNO3 } \\
1 \% \text { HNO3 } \\
\end{array}$ & & & $\begin{array}{l}<0.007 \\
<0.007 \\
<0.009\end{array}$ & \\
\hline $\begin{array}{l}\text { 00-01361-PB-Zr' } \\
00-01361-Z r \\
00-01361-\mathrm{DUP}-\mathrm{Zr} \\
00-01361-\mathrm{Zr}+\text { spike } \\
\text { Spike Recovery }\end{array}$ & $\begin{array}{l}\text { PROCESSBLANK } \\
\text { C-104 Centrifuged Solids Composite } \\
\text { C-104 Centrifuged Solids Composite } \\
\text { C-104 Centrifuged Solids Composite }\end{array}$ & $\begin{array}{l}0.05 \\
0.05 \\
0.05 \\
0.05\end{array}$ & $\begin{array}{l}0.080 \pm \\
0.209 \pm \\
0.314 \pm \\
0.528 \pm \\
102 \%\end{array}$ & $\begin{array}{l}0.001 \\
0.003 \\
0.001 \\
0.012\end{array}$ \\
\hline SRM $2710-Z r$ & LCS/00-01361/Zr & 0.07 & $0.181 \pm$ & 0.011 \\
\hline $\begin{array}{l}0.1 \mathrm{ppb} \text { Pt CCV } \\
0.5 \mathrm{ppb} \text { Pt CCV }\end{array}$ & & & $\begin{array}{r}0.0934 \pm \\
0.445 \pm\end{array}$ & $\begin{array}{r}0.0050 \\
0.003 \\
\end{array}$ \\
\hline
\end{tabular}




\section{C104 Cesium Isotopic Analysis}

June 5, 2000

$\begin{array}{ll}\text { Sample } & \text { Client } \\ \text { ID } & \text { ID }\end{array}$

Barium Standard

True Value

Reagent Blank

\section{ACID DIGESTION}

00-01360-PB

00-01360-BS

$00-01360$

00-01360-DUP

00-01360-MS

\section{Ni/KOH FUSION}

PROCESSBLANK

SRM 2710

00-01361

00-01361-DUP

Client
$35 / 137$

Ratio

Standard

Deviation

$\%$ RSD

Not detectable

Not detectabl

PROCESSBLANK

BLANK SPIKE

C-104 Supernatant Composite

C-104 Supernatant Composite

C-104 Supernatant Composite

\section{LCS/00-01361/Ni}

C-104 Centrifuged Solids Composite

C-104 Centrifuged Solids Composite

Not detectable

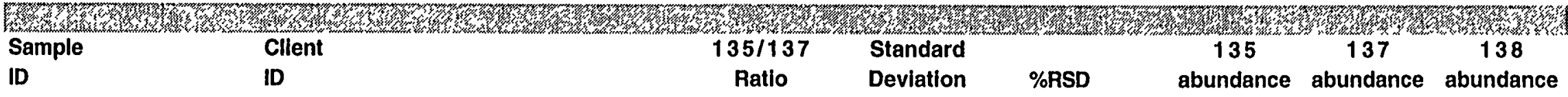

Barium Standard

True Value

Reagent Blank

\section{DIRECT}

00-01360-DB

$00-01360$

00-01360-DUP

00-01360-MS
DILUENT BLANK

C-104 Supernatant Composite

C-104 Supernatant Composite

C-104 Supernatant Composite
Not detectablı

Not detectable

Not detectable

$\begin{array}{lll}0.790 & 0.05 & 5.7 \\ 0.775 & 0.02 & 2.2 \\ 0.782 & 0.04 & 5.4\end{array}$

Not detectable

Not detectable

$\begin{array}{lll}0.789 & 0.01 & 1.3 \\ 0.781 & 0.01 & 1.7 \\ 0.793 & 0.01 & 1.1\end{array}$

135

137

138

abundance abundance abundance
0.0732
0.1255
0.8013
0.0736
0.1264
0.8000

Not detectable
0.762
0.04
5.1
4.9 


\section{Battelle PNNL/RPG/Inorganic Analysis -.- TOC/TIC Report}

Client: $\quad$ BNFL Task 5

ACL Numbers: $00-1360$ and 00-1361

Analyst: $\quad$ MJ Steele
Charge Code/Project: W45439/29274

ASR Number:

5729

Analysis Date:

June 28,2000

Procedure: PNL-AIO-381, "Direct Determination of TC, TOC, and TIC in Radioactive Sludges and Liquids by Hot Persulfate Method"

PNL-ALO-380, "Determination of Carbon in Solids Using the Coulometric Carbon Dioxide Coulometer"

M\&TE: Carbon Analysis System (WA92040); Balance (360-06-01-023).

\section{Final Results:}

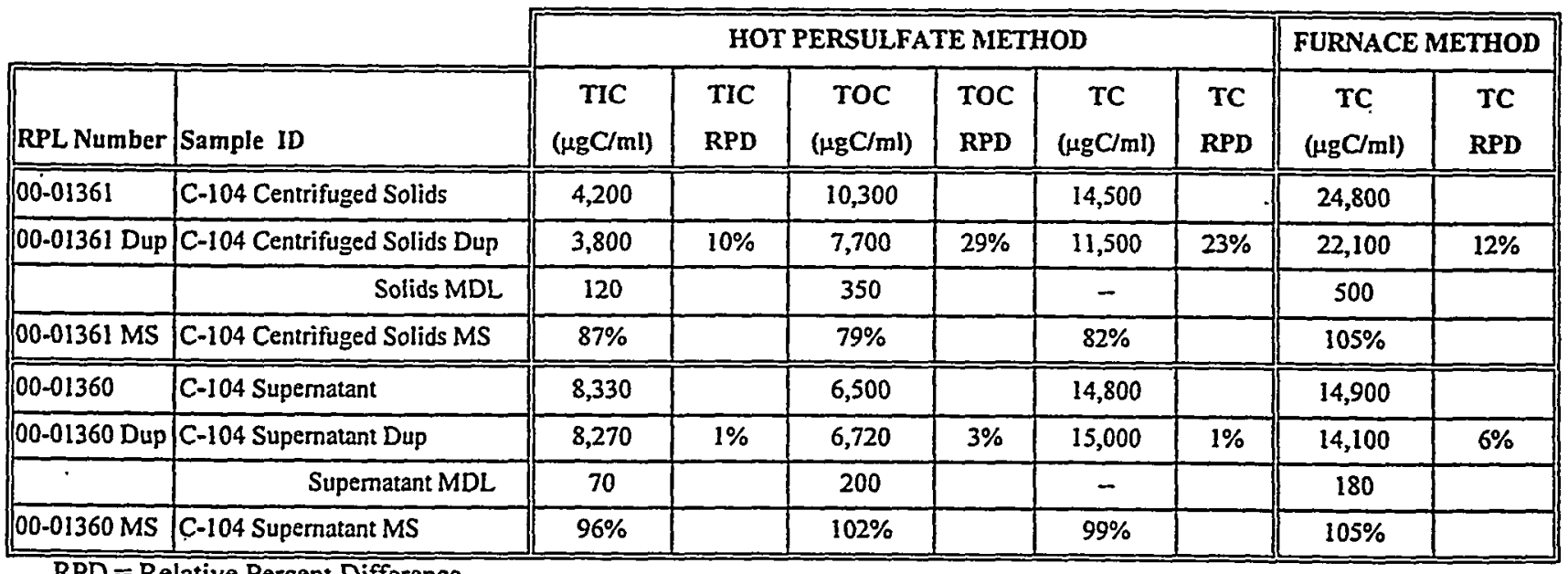

$\mathrm{RPD}=$ Relative Percent Difference

The analysis of the solids and supernatant samples submitted under ASR 5729 was performed by the hot persulfate wet oxidation method and by the furnace oxidation method. The hot persulfate method uses acid decomposition for TIC and acidic potassium persulfate oxidation at $92-95^{\circ} \mathrm{C}$ for TOC, all on the same sample, with TC being the sum of the TIC and TOC. The furnace oxidation method determines TC by oxidizing all forms of carbon (i.e., inorganic and organic) in oxygen at $1000^{\circ} \mathrm{C}$. Under normal conditions, the furnace method and hot persulfate method should provide equivalent $\mathrm{TC}$ results. The supernatant results demonstrated good agreement between the furnace and hot persulfate methods, with the average hot persulfate TC being $14,900 \mu \mathrm{g} / \mathrm{ml}$ and the furnace TC being $14,300 \mu \mathrm{g} / \mathrm{ml}$. However, the agreement between the furnace and hot persulfate TC for the centrifuged solids strongly suggest that carbon compounds (most likely organic carbon compounds) exist that are not well decomposed by the hot persulfate method. That is, the TC for from the furnace methods is nearly twice the level measured in from the hot persulfate method; i.e., approximately 23,000 versus $13,000 \mu \mathrm{g} / \mathrm{g}$, respectively.

The table above shows the results, rounded to two to three significant figures. The raw data bench sheets and calculation work sheets showing all calculations are attached. All sample results are corrected for average percent recovery of system calibration standards and are also corrected for contribution from the blank. 


\section{Battelle PNNL/RPG/Inorganic Analysis --- TOC/TIC Report}

\section{Q.C. Comments:}

The TIC standard is calcium carbonate and TOC/TC standard is $\dot{\alpha}$-Glucose (the certificates of purity are attached). The standard materials were used in solid form for system calibration check standards as well as matrix spikes. The $\mathrm{QC}$ for the methods involves calibration blanks, system calibration standards, sample duplicates, and one matrix spike per matrix type.

Calibration Standards: The QC system calibration check standards were all within acceptance criteria of $90 \%$ to $110 \%$, except for the hot persulfate TOC which demonstrated an average recovery of $88 \%$. Although this recovery is slightly lower than the acceptance criteria, the recovery results were consistent. Since the final results are corrected for the average organic carbon recovery, the slightly low recovery is not expected to significantly effect the results.

Calibration Blanks: The calibration blanks run at the beginning, middle, and end of the analysis runs were acceptable and the standard deviations for the TIC and TOC blanks at or below the historical pooled standard deviation used to establish the method detection limits.

Duplicates: The relative percent difference (RPD) between duplicates was less the acceptance criteria of $20 \%$ for TIC, TOC, and TC, except for the TOC and TC from the hot persulfate method. This is another indication that organic compounds may be present that do not decompose readily in the acidic persulfate environment.

Matrix Spike: The accuracy of the carbon measurements can be estimated by the recovery results from the matrix spike. All spike recoveries were within the acceptance criteria of $75 \%$ to $125 \%$. However, the matrix spike for the hot persulfate method demonstrated somewhat low recoveries from $79 \%$ to $87 \%$ for TIC, TOC, and TC for the solids matrix. Although these recoveries are within the acceptance criteria, the low recoveries again indicate some difficulties either in subsampling the solids sample or in ability of the hot persulfate method to produce consistent results from the specific sample matrix.

Laboratory Control Sample: No LCS is included in the carbon analysis procedure.

\section{General Comments:}

- The reported "Final Results" have been corrected for all dilution performed on the sample during processing or analysis.

- Routine precision and bias are typically $\pm 15 \%$ or better for non-complex samples that are free of interferences.

- The estimated quantitation limit (EQL) is defined as 5 times the MDL. Results less than 5 times the MDL have higher uncertainties, and RPDs are not calculated for any results less than 5 times the MDL.

- Some results may be reported as less than ("<") values. These less than values represent the sample MDL (method detection limit), which is the system MDL adjusted for the volume of sample used for the analysis. The system MDL is based on the attached pooled historical blank data. The evaluation and calculation of the system MDL is included in the data package.

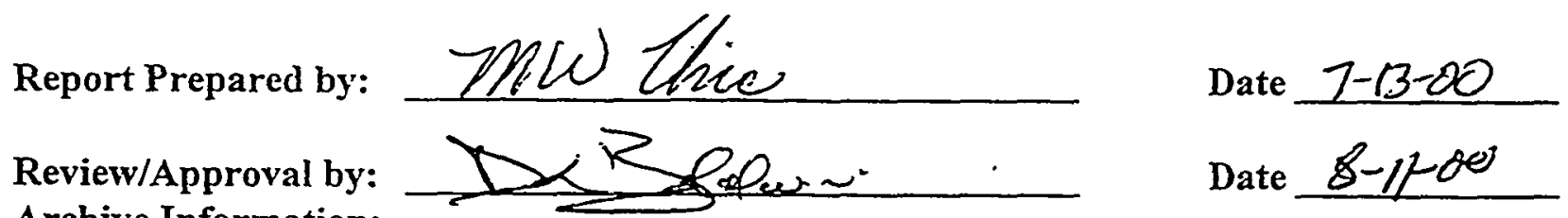
Archive Information: Files: ASR 5729 Urie.doc ASR 5729 Urie Persulfate.xls ASR 5729 Urie Furnace.xls 


\section{Battelle PNNL/RPG/Inorganic Analysis --: IC Report}

\begin{tabular}{|c|c|c|c|}
\hline Client: & BNFL/Task 5 & Charge Code/Project: & 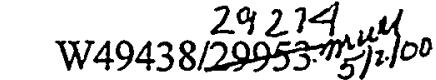 \\
\hline RPL Numbers: & $00-1360,1361$ & ASR Number: & 5729 \\
\hline Analyst: & MJ Steele & Analysis Date: & April 23-24, 2000 \\
\hline
\end{tabular}

Procedure: PNL-ALO-212, "Determination of Inorganic Anions by Ion Chromatography"

M\&TE: IC system (WD25214); Balance (360-06-01-031) --- See Chemical Measurement

Center 98620 RIDS IC File for Calibration, Standards Preparations, and Maintenance Records.

\section{Final Results:}

\begin{tabular}{|c|c|c|c|c|c|c|c|c|c|c|}
\hline 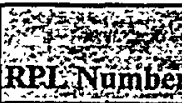 & 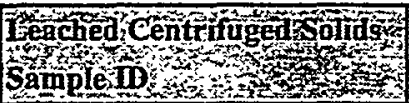 & 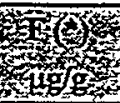 & Hgitg & $\operatorname{ton} 2$ & 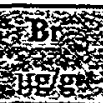 & tos & Pogg & tos & & \\
\hline & & et Weigh & Basis (a & Analyze & & & & & & Dil Fctr \\
\hline $00-1361 \mathrm{~PB}$ & C-104 Solids Prep Blank & $<25$ & 26 & $<50$ & $<25$ & $<50$ & $<50$ & $<50$ & $<50$ & 96.17 \\
\hline $00-1361$ & C-104 Cent. Solids & 49,200 & 260 & 11,200 & 1,090 & 5,990 & 10,300 & 1,520 & 8,180 & 97.15 \\
\hline 00-1361Dup & C-104 Cent. Solids Dup & 50,100 & 230 & 10,900 & 1,060 & 5,790 & 2,700 & 1,460 & 7,710 & 95.20 \\
\hline & RPD & $2 \%$ & $12 \%$ & $3 \%$ & $3 \%$ & $3 \%$ & $117 \%$ & $4 \%$ & $6 \%$ & \\
\hline $00-1361 \mathrm{MS}$ & C-104 Cent. Solids MS \%Rec & OvrRng & $108 \%$ & $100 \%$ & $105 \%$ & $108 \%$ & $104 \%$ & $107 \%$ & $102 \%$ & \\
\hline & Wet Weig & Basis (a & usted $\mathbf{t}$ & Initial V & $\%$ Solic & & & & & Adj. Factor \\
\hline $00-1361 \mathrm{~PB}$ & C-104 Solids Prep Blank & $<24.0$ & 26.1 & $<48.1$ & $<24.0$ & $<48.1$ & $<48.1$ & $<48.1$ & $<48.1$ & 0.95 \\
\hline $00-1361$ & C-104 Cent. Solids & 46,200 & 250 & 10,500 & 1,020 & 5,630 & 9,650 & 1,430 & 7,690 & 0.94 \\
\hline 00-1361Dup & C-104 Cent. Solids Dup & 48,300 & 220 & 10,500 & 1,020 & 5,590 & 2,600 & 1,410 & 7,440 & 0.97 \\
\hline & RPD & $4 \%$ & $13 \%$ & $0 \%$ & $0 \%$ & $1 \%$ & $115 \%$ & $1 \%$ & $3 \%$ & \\
\hline & & $\overline{\mathbf{D r}}$ & Veight & sis & & & & & & Wt\% Solids \\
\hline $00-1361 \mathrm{~PB}$ & C-104 Solids Prep Blank & $<40$ & 42 & $<80$ & $<40$ & $<80$ & $<80$ & $<80$ & $<80$ & 59.10 \\
\hline $00-1361$ & C-104 Cent. Solids & 78,700 & 420 & 17,900 & 1,740 & 9,570 & 16,400 & 2,430 & 13,100 & 58.76 \\
\hline 00-1361Dup & C-104 Cent. Solids Dup & 81,300 & 370 & 17,600 & 1,720 & 9,410 & 4,400 & 2,380 & 12,500 & 59.43 \\
\hline & RPD & $3 \%$ & $13 \%$ & $2 \%$ & $1 \%$ & $2 \%$ & $115 \%$ & $2 \%$ & $5 \%$ & \\
\hline
\end{tabular}

\begin{tabular}{|c|c|c|c|c|c|c|c|c|c|}
\hline 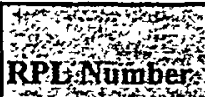 & 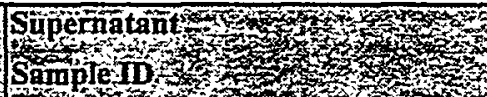 & agrag & 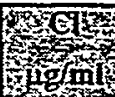 & 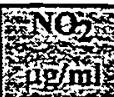 & inping & SNO3, & Pof & ThO & 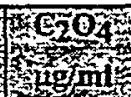 \\
\hline $00-1360$ & C-104 Supernatant Comp. & 9,710 & 790 & 34,200 & 3,270 & 17,600 & 3,040 & 3,870 & 3,590 \\
\hline \multirow[t]{2}{*}{ 00-1360 Dup } & C-104 Supernatant Comp. Dup & 9,500 & 720 & 29,100 & 2,920 & 16,100 & 2,640 & 3,410 & 3,260 \\
\hline & $\overline{\mathrm{RPD}}$ & $2 \%$ & $9 \%$ & $16 \%$ & $11 \%$ & $9 \%$ & $14 \%$ & $13 \%$ & $10 \%$ \\
\hline \multirow[t]{2}{*}{$00-1360 \mathrm{MS}$} & C-104 Supernatant Comp. MS \%Rec & $\bar{n} / \mathrm{a}$ & $106 \%$ & $81 \%$ & $100 \%$ & $112 \%$ & $109 \%$ & $108 \%$ & $107 \%$ \\
\hline & Blank Spike \%Recovery & $110 \%$ & $107 \%$ & $105 \%$ & $108 \%$ & $78 \%$ & $104 \%$ & $106 \%$ & $107 \%$ \\
\hline
\end{tabular}

RPD $=$ Relative Percent Difference

MS \%Rec = Matrix Spike Standard \% Recovery

$\left.{ }^{*}\right)$ Use fluoride results with reservation; IC system can not resolve fluoride, acetate, and formate

The $\mathrm{C}-104$ composite samples (00-1360 supernatant and 00-1361 centrifuged solids) were analyzed in duplicate by ion chromatography (IC) for inorganic anions as specified in Test Plan BNFL-29953-030. The final results are presented in the table above. All analytical samples 


\section{Battelle PNNL/RPG/Inorganic Analysis --- IC Report}

were diluted 10 to 2000 fold at the IC workstation to ensure that all anions reported were measured within the calibration range.

The wet centrifuged solids were originally sub-sampled at the same time as all other analytical sub-samples to ensure that all analyses would use the same weight percent solids (of the centrifuged solids) when reporting concentrations on a dry weight basis. Unfortunately the IC sub-samples has to be re-sampled due to a problem encountered during the leaching operation. At the time of the re-sampling, a weight percent solids was performed. This weight percent solids showed a slight loss in water due to some drying of the wet centrifuged solids. A ratio of the original weight percent solids to the resample weight percent solids has been used to adjust the measured IC results to the original sub-sample concentration. This allows direct comparison of the IC results with other analytical results on the wet centrifuged solids. Once adjusted, the IC results have been reported on a dry weight basis using the original weight percent solids results.

For IC column and parameters used, the IC system can not separate fluoride, acetate, and formate; the IC system quantifies and reports all as fluoride. It is unlikely that the levels of fluoride quantified are present in the tank waste, and since both acetate and formate could be present in the C-104 sample, the fluoride results should be used with reservation.

\section{Q.C. Comments:}

Duplicates: Duplicate water leaches of wet centrifuged solids sample 00-1361 were performed in the SAL, along with a water leach processing blank. Duplicates for the supernatant sample 00-1360 were prepared at the IC workstation. All RPDs are within the acceptance criteria of $20 \%$, except for phosphate on the water leach of the wet centrifuged solids. The effectiveness of the water leach to maintain phosphate in solution is considered the primary cause of the large discrepancy in the phosphate results.

Matrix Spike: Matrix spikes was prepared for both the leached solids and supernatant samples and all anion recoveries were within the $75 \%$ to $125 \%$ recovery acceptance criteria. However, the fluoride matrix spike for the leached solids was over-range and could not be quantified; the spike concentration was about one-tenth the sample concentration making the fluoride MS meaningless.

Blank Spike: The working spike (i.e., the spike solution used to prepare the matrix spike samples) was diluted and measured at the same time as the Matrix Spike samples and demonstrated recoveries within the $90 \%$ to $110 \%$ acceptance criteria, except for nitrate. Other standards analyses during the analytical run demonstrated good nitrate recovery and the poor nitrate recovery from the blank spike is not considered to affect the reported results. 


\section{Battelle PNNL/RPG/Inorganic Analysis --- IC Report}

System Blank/Processing Blanks: Five system blanks were processed during the analysis of the liquid sample. No anions were detected in the system blanks above the estimate quantitation level.

Quality Control Calibration Verification Check Standards: Four mid-range verification standards were analyzed throughout the analysis runs. For most of the anions recoveries were within the acceptance criteria from $90 \%$ to $110 \%$ for the verification standard. However, due to column degradation caused by a sample from another ASR, one verification standard produced low recoveries (i..e., $80 \%$ to $90 \%$ ). Column performance was recovered following continued use (i.e., flushing by the eluent), and the reported results are considered valid.

\section{General Comments:}

- The reported "Final Results" have been corrected for all dilution performed on the sample during processing or analysis.

- The low calibration standards are defined as the estimated quantitation limit (EQL) for the reported results and assume non-complex aqueous matrices. Actual detection limits or quantitation limits for specific sample matrices may be determined, if requested.

- Routine precision and bias are typically $\pm 15 \%$ or better for non-complex aqueous samples that are free of interference and have similar concentrations as the measured anions.
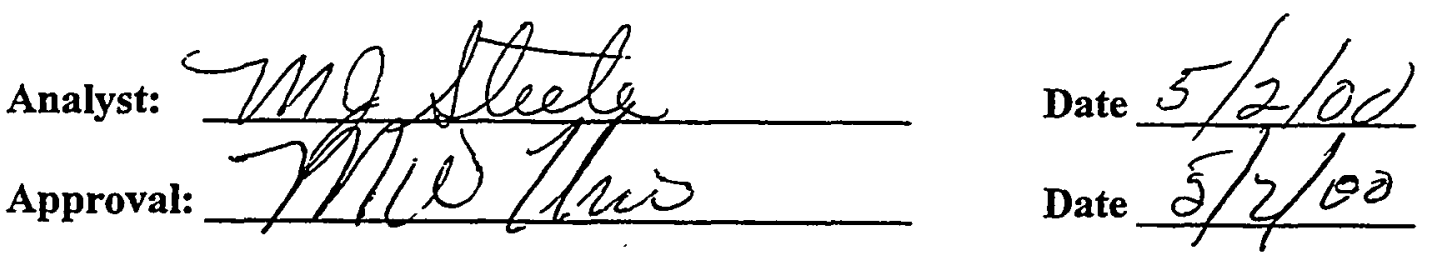

Archive Information:

Files: ASR 5729 Urie.doc

ASR 5729 5784-86 5778.xls 
WO/Project:

Client:
W49436/29274

M. Urie

RPL Numbers: 00-01360 \& 00-01361

ASR Number 5729

Procedure: PNNL-ALO-131, "Mercury Digestion"

PNNL-ALO-201, "Mercury Analysis"

Analyst: J. J. Wagner

Digestion Date: May 10, 2000 Analysis Date: May 11, 2000

M\&TE: Hg system (WD14126); Mettler AT400 Balance (360-06-01-029).

See Chemical Measurement Center $98620 \mathrm{RIDS}$ for $\mathrm{Hg}$ File for Calibration, Standards Preparations, and Maintenance Records.

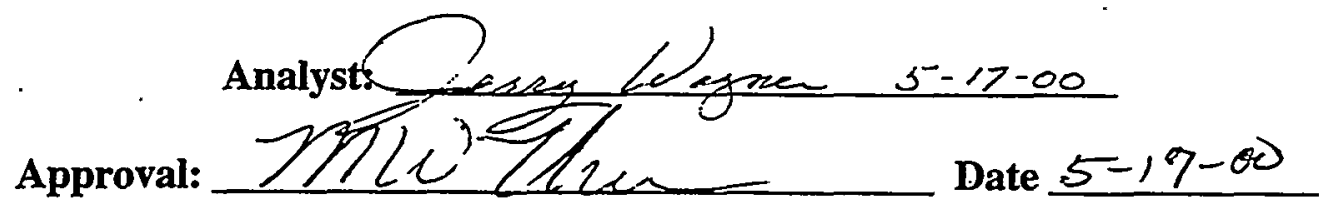

\section{Final Results:}

The samples were analyzed by cold vapor atomic absorption spectrophotometry for inorganic mercury as specified in ASR 5729." Approximately $0.10 \mathrm{~g}$ weight of centrifuged solids and approximately $0.5 \mathrm{ml}(0.57 \mathrm{~g}$ weight) of supernatant liquid samples were transferred to glass digestion vessels by SAL. Samples were processed and diluted to a final volume of $25.5 \mathrm{ml}$ to $27 \mathrm{ml}$ per procedure ALO-131. Supernatant samples were processed with $0.5 \mathrm{~g}$ additional potassium permanganate. Centrifuged solids were processed with $1 \mathrm{~g}$ additional potassium permanganate. The increased amount of potassium permanganate was used to ensure completè oxidation of potential organic material in the samples. Processed blanks, blank-spike and matrixspiked samples were all treated similarly. Analytical dilution of 2 to 51 -fold was necessary for some samples. The mercury concentration results are presented in the table below. 


\begin{tabular}{|c|c|c|c|c|c|c|c|}
\hline & & Liplo & holut & 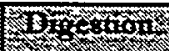 & 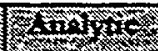 & 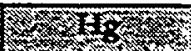 & Thon \\
\hline W & 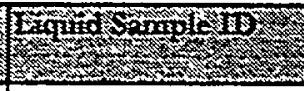 & 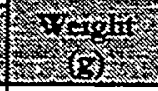 & (m) & 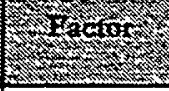 & S & $f_{1}$ & $\left.h^{2}+6\right)$ \\
\hline $00-01360-\mathrm{PB}$ & Process Blank & & $\# 0.5$ & 51 & 1 & 0.014 & \\
\hline $00-01360$ & $\begin{array}{l}\text { C-104 Supematant } \\
\text { Composite }\end{array}$ & 0.5795 & 0.5 & 51 & 5 & 0.722 & \\
\hline 00-01360DUP & $\begin{array}{l}\text { C-104 Supernatant } \\
\text { Composite }\end{array}$ & 0.5729 & 0.5 & 51 & 5 & 0.602 & 20 \\
\hline
\end{tabular}

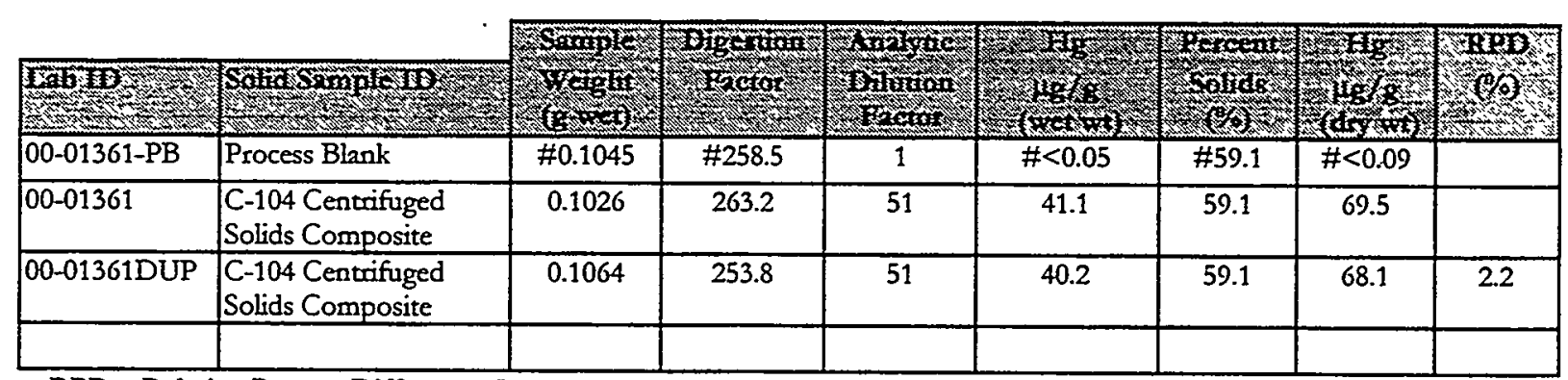

RPD = Relative Percent Difference (between sample and duplicate/replicate)

$N / A=R P D$ is not calculated when results are less than $5 \times$ IDL

“*” Field duplicate samples

“\#” Volume or weight and \%solids for the process blank are averages of sample volumes or weights and \%solids.

\section{Notes:}

1) "Final Results" have been corrected for all dilution performed on the sample during processing or analysis.

2) The low calibration standard is defined as the estimated detection limit (IDL) for the reported results and assumes non-complex aqueous matrices. Actual detection limits or quantitation limits for specific sample matrices may be determined, if requested.

3) Routine precision and bias is typically $\pm 15 \%$ or better for non-complex aqueous samples that are free of interference.

\section{Q.C. Comments:}

Following are results of quality control checks performed during $\mathrm{Hg}$ analyses. In general, quality control checks met the requirements of the governing QA Plan.

Process Blank Spike (liquids \& solids): Process Blank Spike recovery (104\% and 108\% respectively) is within the acceptance criteria of $80 \%$ to $120 \%$.

Matrix Spiked Sample (liquids): A matrix spike was prepared for the supernatant samples submitted under ASR-5729. Recovery of the matrix spike (96\%) is within acceptance criteria of $75 \%$ to $125 \%$.

Matrix Spiked Sample (solids): A matrix spike was also prepared for the solids samples submitted under ASR-5729. Recovery of the matrix spike could not be determined because high concentration in the solids sample was approximately 160 times greater than the spike concentration. 
Duplicate Relative Percent Difference (liquids): RPD for duplicate supernatant samples is just within acceptance criteria of $\leq 20 \%$ RPD for RPL\# 00-01360, 00-01360D (20\% RPD).

Duplicate Relative Percent Difference (solids): RPD for duplicate solid samples is well within acceptance criteria of $\leq 20 \%$ RPD for RPL\# 00-01361, 00-01361D (2\% RPD).

Laboratory Control Sample (solids): Sample recovery of mercury in SRM-2709 San Joaquin Valley Soil certified by NIST to contain $1.40 \pm 0.08 \mu \mathrm{g} / \mathrm{g}$ was recovered within acceptance criteria of $75 \%$ to $125 \%$. LCSS recovery is $107 \%$ and $113 \%$ for the two aliquots.

Laboratory Control Sample (liquids): Sample recovery of mercury in SRM-1641d "Mercury in $\mathrm{H}_{2} \mathrm{O}$ " certified by NIST to contain $1.60 \mu \mathrm{g} / \mathrm{ml}$ was recovered (100\% and $102 \%$ ), well within acceptance criteria of $75 \%$ to $125 \%$.

Process Blanks: The separately prepared process blank concentrations for the solid and liquid prepared samples were both less than two times detection limit. The concentration in the process blanks was less than about 50-times that measured in either the liquid or solid samples.

Quality Control Calibration Verification Check Standards: Three mid-range verification standards were analyzed throughout the analysis run. All were within the acceptance criteria of $80 \%$ to $120 \%$ recovery for the verification standard. The measured concentrations varied from a minimum of $96 \%$ recovery to a maximum of $105 \%$ recovery. 
Date June 21,2000

To BNFL

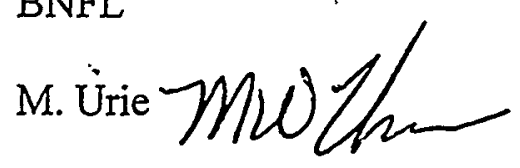

Subject Cyanide Results for C-104

Table 1: Total CN Results

\begin{tabular}{|l|c|c|c|c||}
\hline \multirow{2}{*}{ Sample ID } & \multicolumn{2}{|c|}{ C-104 Supernatant } & \multicolumn{2}{c|}{ C-104 Wet Centrifuged Solids } \\
\cline { 2 - 5 } & RPL Number & CN (ug/mL) & RPL Number & CN (ug/g) \\
\hline \hline Cell Blank & $00-1360$ cell blk & $<0.01$ & $00-1361$ cell blk & $<0.04$ \\
\hline C-104 Sample & $00-1360$ & 7.4 & $00-1361$ & 11.4 \\
\hline C-104 Duplicate & $00-1360 \mathrm{~d}$ & 8.5 & $-00-1361 \mathrm{~d}$ & 13.8 \\
\hline$\cdot$ & & 14 & & 19 \\
\hline RPD (\%) & & 94 & & 111 \\
\hline
\end{tabular}

The $\mathrm{CN}$ analyses for $\mathrm{C}-104$ supernatants and wet centrifuged solids were performed on May 11, 2000 and June 12,2000, respectively. The results are presented in Table 1. Due to dose, the samples were weighed into the distillation tubes in the Shielded Analytical Laboratory and then transferred to the CN Workstation for distillation and analysis. The samples were distilled with the addition of sulfamic acid to ensure there would be no interference from high nitrates present in the sample. The samples were analyzed using a Lachat QuickChem AE Autoanalyzer (WC36517). Based on the average sample sizes taken for analysis and the analytical dilutions applied, the method detection limits (MDL) are estimated at $0.250 \mu \mathrm{g} / \mathrm{ml}$ for the supernatant samples and $0.2 \mu \mathrm{g} / \mathrm{g}$ for the solids samples.

All sample preparation sheets, standard preparation information, and analytical data aretincluded with this report

\section{QC Evaluation:}

No quality control or other measurement problems were encountered during either analysis run. However, the results reported represent results obtained from reruns of the C-104 supernatant and solid, since an initial analysis produced very inconsistent results and multiple $Q C$ failures.

The independent mid-range calibration check solution run at the beginning, middle, and end of the analysis batch on each day gave recoveries ranging from $97 \%$ to $101 \%$; each recovery was within the $85 \%$ to $115 \%$ acceptance criteria of the governing QA plan.

The C-104 supernatant and solids were each analyzed in duplicate. The Relative Percent Difference (RPD) between the sample and duplicate was $14 \%$ for the supernatant and $19 \%$ for the wet centrifuged solids. Although the RPDs are within the acceptance criteria of $20 \%$, they are higher than normal. The relatively 
BNFL

June 21, 2000

Page 2

small sample sizes used to minimize personnel exposure are most likely a major contributor to the poor precision.

For the C-104 supernatants, a distilled Blank Spike sample was used as the Laboratory Control Sample (LCS). The Blank Spike recovery was $101 \%$, well within the acceptance criteria of $80 \%$ to $120 \%$. For the C-104 solids, a solid LCS (ERA PriorityPollutnt ${ }^{\mathrm{TM}}$ ) was analyzed. The solid LCS was analyzed at $165 \mu \mathrm{g} / \mathrm{g}$ and $173 \mu \mathrm{g} / \mathrm{g}$, well within the certified advisory range of $77 \mu \mathrm{g} / \mathrm{g}$ to $301 \mu \mathrm{g} / \mathrm{g}$.

The spike recovery for the C-104 supernatant spike was $94 \%$ and for the wet centrifuged solids was $111 \%$, well within the acceptance criteria of $75 \%$ to $125 \%$. The small sample sizes used for the analyses and the apparent sample heterogeneity (i.e., high RPDs) significantly impact the recovery calculation. Therefore, for both the supernatants and the solids the average cyanide concentration (i.e., average of sample and duplicate) has been used to calculate spike recoveries.

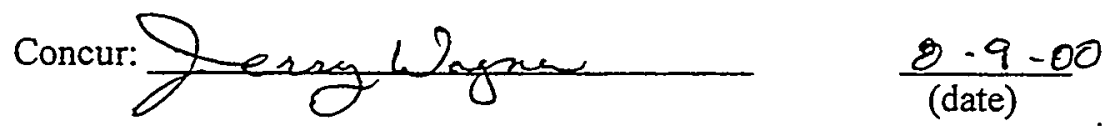


Battelle Pacific Northwest Laboratory

Radiochemical Processing Group-325 Building

Chemical Measurements Center
$00-1360 \mathrm{NH} 3$

$8 / 10 / 00$

Client: M. Urie

Cognizant Scientist:

Concur :

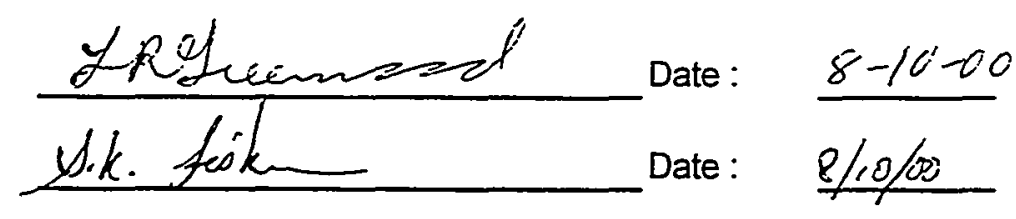

Measured Concentration with 1- $\sigma$ error

ALO ID

Client ID

$\mathrm{NH}_{3}$

Error \%

00-1360

C-104 Supernatant Comp.

$1.74 \mathrm{E}+1 \quad \mu \mathrm{g} / \mathrm{ml}$

$8 \%$

00-1360 Dup

C-104 Supernatant Comp.

$1.92 \mathrm{E}+1 \quad \mu \mathrm{g} / \mathrm{ml}$

$8 \%$

RPD

$10 \%$

00-1361

C-104 Centrifuged Solids Comp.

$3.38 \mathrm{E}+0 \quad \mu \mathrm{g} / \mathrm{g}$

$7 \%$

00-1361 Dup .

C-104 Centrifuged Solids Comp.

$3.09 \mathrm{E}+0 \quad \mu \mathrm{g} / \mathrm{g}$

$7 \%$

$9 \%$

00-1361 Process Blank

$1.05 \mathrm{E}+0 \quad \mu \mathrm{g} / \mathrm{g}$

$11 \%$

Note: Concentrations are reported per gram of wet solids for the centrifuged solids. 
Battelle Pàcific Northwest Laboratory

Radiochemical Processing Group-325 Building

Chemical Measurements Center.

Hydroxide and Alkalinity Determination-- also including $\mathrm{pH}$ detrmination

Governing Procedures: PNL-ALO-228: Determination of Hydroxyl (OH-), $\mathrm{PH}$ and

Alkalinity of Aqueous Solutions, Leachates and Supernates

and Operation of Brinkman 636 Auto-Titrator

Equip \# .WB76843

Lab Loc. $\quad 525$

\section{ASR \#}

5729

WPH

W49436 $\because$
File: L:Iradelıenlhydroxidelasr" 5729

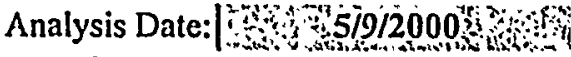
Print Date: 6/9/00

\section{Concentration, moles/liter}

\begin{tabular}{ll} 
RPG \# & Client ID \\
\hline $00-01360$ & C104-composite. \\
$00-01360$ & C104-composite.
\end{tabular}

\begin{tabular}{|c|c|}
\hline First Point & Sccond Poi \\
\hline 0.81 & 0.77 \\
\hline 0.82 & 0.79 \\
\hline $0 \%$ & $3 \%$ \\
\hline
\end{tabular}

Reag. Blk.

o

Standard 1

$100 \%$

Standard 2

$101 \%$

00-01360MS Matrix spike

$98 \%$

Note: Results are presented for the first, second, and third inflection points on the titration curves, as applicable. The first inflection point is generally associated with the hydroxide concentration. The second and third points generally represent the carbonate and bicarbonate concentrations. 


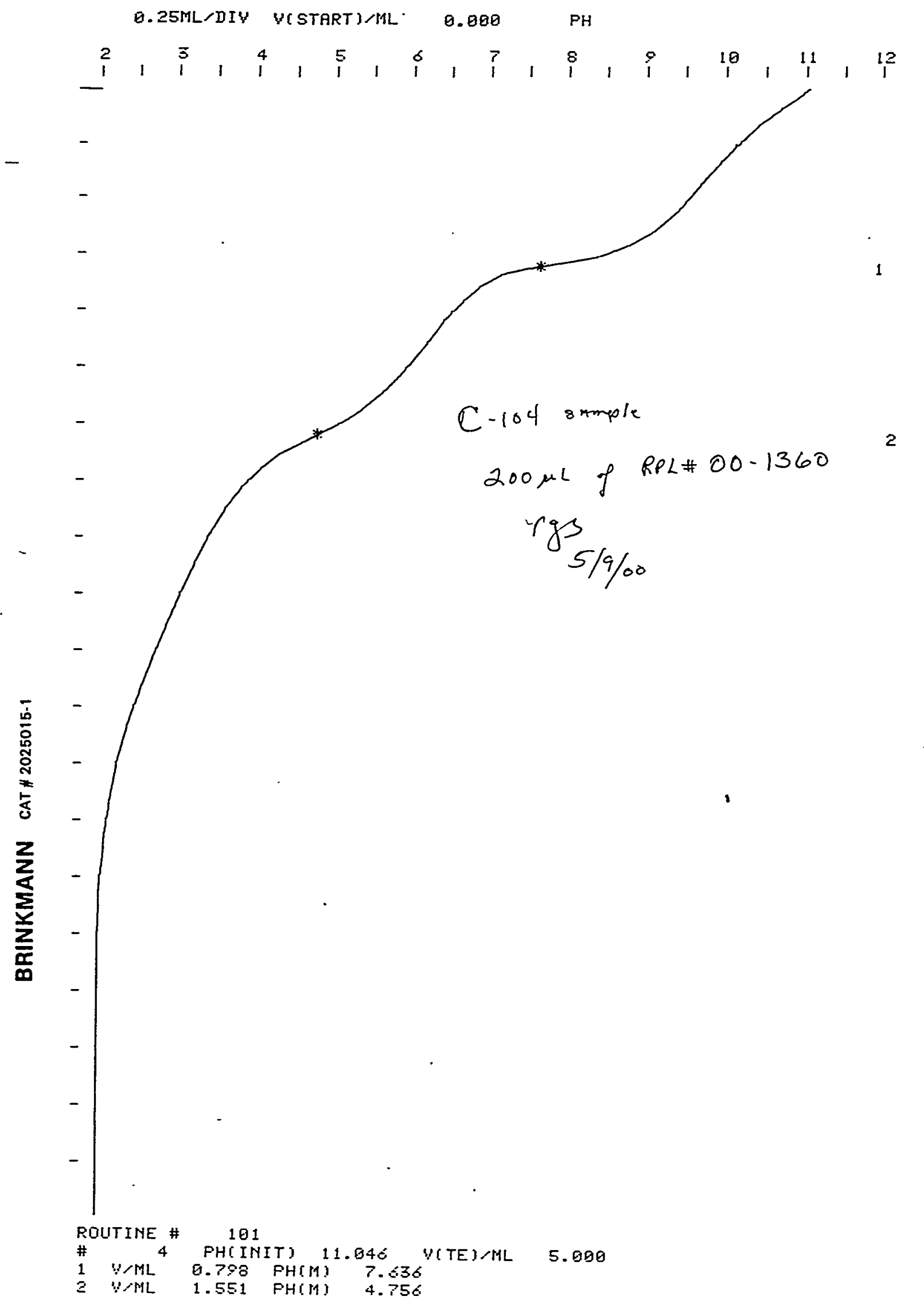


Analytical Chemistry Laboratory

Shielded Analytical Laboratory

pH Analysis

Page 1 of 1

(Sample Receiving and Prep Laboratory)

client: M. Uric

ASRAAFFLIITI: ASR-5729

Work Package: $\quad M M C$ aA Plan: Impact Level:

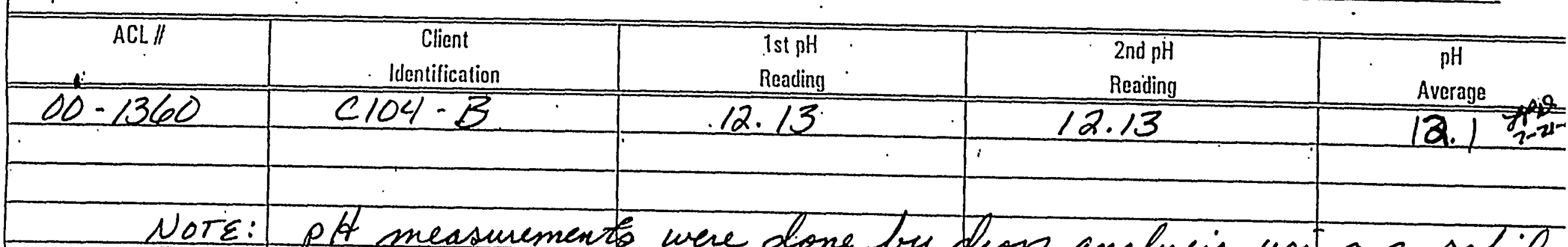

NoTE: pt t measurement e wee done by chop analysis wong a solid

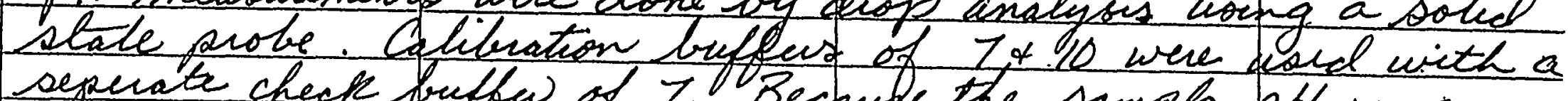

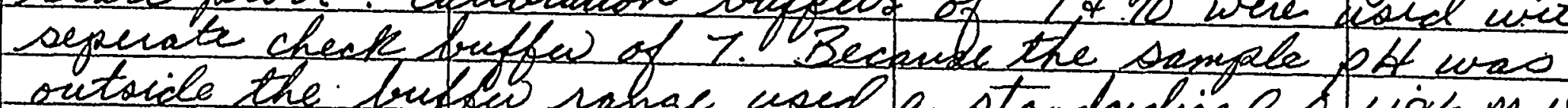
outside the bu f range used a standardized o. $1186 \mathrm{M} \mathrm{NaOH}$

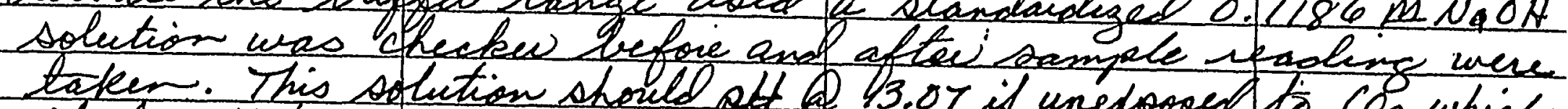
taken. This solution should pt Q 13.07 if unexposed to $\mathrm{CO}_{2}$ which

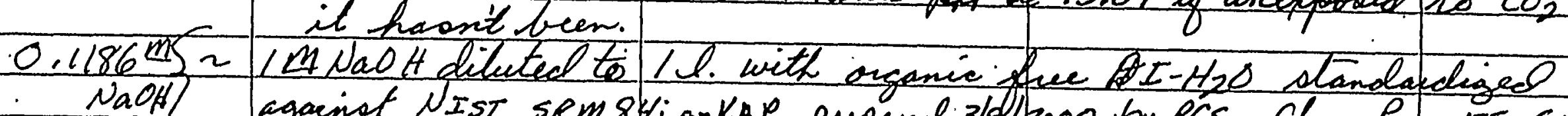

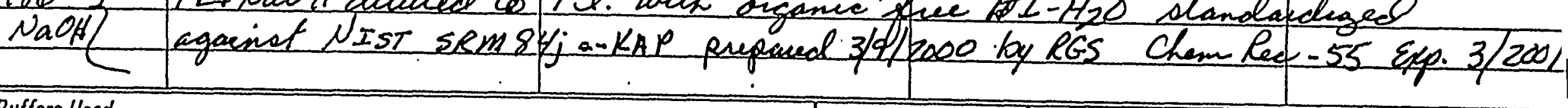

Calibration Buffers Used

$\mathrm{pH} \frac{(7)}{\mathrm{pH}}$ Lot $/ 1$

Beginning Check: $\quad 7.01$ Exp. Date

BCD

Section 200
Analyst: Lori T. Nair
Reviewer: U.K. Chook Ending Check: 7.01

0. 侁 NaOH $\mathrm{pH}=12.83$

$$
\mathrm{pH}=\frac{7.07}{12.83}
$$




\section{Distribution}

PNNL-13364

WTP-RPT-007, Rev. 0

(Formerly BNFL-RPT-043)

No. of

No. of

Copies

Copies

OFFSITE

ONSITE

2 DOE/Office of Scientific and Technical Information

$4 \quad$ CH2M Hill Hanford Group

M. E. Johnson (4) H4-10

A. N. Thompson H4-02

1 Harold Sturm

Savannah River Technology Center

PO Box 616, Road 1

Building 773-A, Room A-233

Aiken, SC 29808

1 Paul Townson

BNFL, Inc

3000 George Washington Way

Richland, WA 99352

$24 \quad$ Pacific Northwest National Laboratory

C. J. Barinaga P7-07

J. P. Bramson P8-08

K. J. Carson P7-25

J. R. DesChane P7-25

O. T. Farmer P8-08

S. K. Fiskum P7-22

L. R. Greenwood P7-22

F. V. Hoopes P7-22

R. T. Ratner P7-22

D. R. Sanders P7-22

M. J. Steele P7-22

R. T. Steele P7-22

C. Z. Soderquist P7-22

R. G. Swoboda P7-22

K. K. Thomas P7-22

T. L. Trang-Le P7-22

M. W. Urie P7-22

J. J. Wagner P7-22

Project File P7-28

Technical Report Files (5) K1-06

Distr.1 